The Absorption, Distribution and Excretion of Inhaled Hydrogen Fluoride in the Rat

by

John Bennett Morris

Submitted in Partial Fulfillment

of

Requirements for the Degree

DOCTOR OF PHILOSOPHY

Supervised by Dr. Frank A. Smith

Department of Radiation Biology and Biophyics

The University of Rochester

School of Medicine and Dentistry

Rochester, New York 


\section{DISCLAIMER}

This report was prepared as an account of work sponsored by an agency of the United States Government. Neither the United States Government nor any agency Thereof, nor any of their employees, makes any warranty, express or implied, or assumes any legal liability or responsibility for the accuracy, completeness, or usefulness of any information, apparatus, product, or process disclosed, or represents that its use would not infringe privately owned rights. Reference herein to any specific commercial product, process, or service by trade name, trademark, manufacturer, or otherwise does not necessarily constitute or imply its endorsement, recommendation, or favoring by the United States Government or any agency thereof. The views and opinions of authors expressed herein do not necessarily state or reflect those of the United States Government or any agency thereof. 


\section{DISCLAIMER}

Portions of this document may be illegible in electronic image products. Images are produced from the best available original document. 


\title{
The Absorption, Distribution and Excretion \\ of Inhaled Hydrogen Fluoride in the Rat
}

John Bennett Morris

Submitted in Partial Fulfillment

of

Requirements for the Degree

DOCTOR OF PHILOSOPHY

\author{
Supervised by Dr. Frank A. Smith \\ Department of Radiation Biology and Biophyics \\ The University of Rochester \\ School of Medicine and Dentistry \\ Rochester, New York
}


John Bennett Morris was born November 12, 1951 in Rochester, New York. He was graduated from Pittsford High School, Pittsford, New York in 1969. He attended Allegheny College, Meadville, Pennsylvania where he received a Bachelor of Science degree, cum laude, in Chemistry in 1973. In 1976 he received a Master of Science degree in Toxicology from the Department of Radiation Biology and Biophysics, University of Rochester, Rochester, New Yor $k$. 
ACKNOWLEDGEMENTS.

I am deeply indebted to my advisor Dr. Frank A. Smith for his advice, patience, unequalled ability as an educator and for his friendship.

I would like to thank the members of my advisory committee:

Dr. Paul E. Morrow, Dr. Franklin W. Heggeness, Dr. John C. Smith and Mr. Leonard J. Leach for their time and many helpful suggestions. I would also like to thank Dr. Raymond B. Baggs and Dr. Robert H. Garman for their assistance with the histologic examination.

I am grateful to all the other students in Dr. Smith's lab especially Dr. Paul J. Kostyniak and Judy Sullivan for the many stimulating discussions we have had.

Many thanks go to the Word Processing Center in particlilar to Elaine Shepardson and Nancy scott for the typing and for their good humor while preparing this manuscript.

Finally I would like to thank Dr. George G. Berg who, many years ago, whetted my appetite for research.

This thesis is supported in part by U.S.P.H.S.-N.I.H. Toxicology Training Grant 5-T32-ES-07026 and in part under contract with the U.S. Department of Energy at the University of Rochester, Department of Radiation Biology and Biophysics. 
The experiments described in this thesis were performed to obtain quantitative information on the absorption, distribution and excretion of inhaled hydrogen fluoride. Male Long Evans rats were subjected to whole body HF exposure for 6 hours or to nose-only HF exposure for 1 hour. Total (ashed samples) and/or ionic (unashed samples) fluoride concentrations in lung, plasma, kidney, trachea, fenur, urine and feces were determined at various times following exposure. Both total and ionic lung, plasma and kidney concentrations were determined, the difference, referred to as the $\Delta F$ fraction, being attributed to the presence of a fluoride specie(s) which did not respond to the fluoride ion sensitive electrode.

In rats sacrificed 6 hours after whole body exposure to 11-179 $\mathrm{mg} \mathrm{F} / \mathrm{m}^{3} \mathrm{HF}$ dose-dependent increases in lung, plasma and kidney total and ionic fluoride concentration occurred. Plasma ionic fluoride ranged from $0.6 \mu \mathrm{g} / \mathrm{ml}$ after exposure to $11 \mathrm{mg} \mathrm{F} / \mathrm{m}^{3}$ to $5.7 \mu \mathrm{g} / \mathrm{ml}$ after exposure to $116 \mathrm{mg} \mathrm{F} / \mathrm{m}^{3}$ (control 0.03 $\mu \mathrm{g} / \mathrm{ml})$. In addition, a dose-dependent increase in plasma $\Delta F$ concentration was evident. Plasma $\Delta F$ concentration averaged 7-188 of the plasma total fluoride concentration and was strongly correlated with the log of the plasma total fluoride concentration. The source of this $\Delta F$ is unknown. Rats excreted many times more fluoriaj in the urine after whole body exposure to HF than could be explained by the amount of HF inhaled. The results of these experiments provide considerable evidence that 
airborne $H F$ deposits on $f u r$ and is then ingested due to preening activity.

Urinary fluoride excretion was increased by nose-only exposure to $63 \mathrm{mg} \mathrm{F} / \mathrm{m}^{3} \mathrm{HF}$. Approximately 908 of the excess fluoride excreted as a result of exposure was eliminated within 24 hours of the start of 1 hour exposure, the remainder was excreted the following day. The urinary fluoride excretion accounted for approximately twice the fluoride estimated to be inhaled during exposure. The amount of fluoride present on the fur covering the nose was of sufficient magnitude to account for the difference.

Tissue fluoride concentrations were elevated immediately after nose-only exposure. Fluoride concentrations in lung and kidney returned to control levels within 12 hours. Plasma fluoride concentration was slightly elevated 24 hours after the start of the 1 hour exposure but was at control levels at 96 hours. Immediately following nose-only exposure lung ionic fluoride concentrations were less than plasma ionic fluoride concentrations suggesting that the fluoride in the lung had reached that site via plasma transport rather than by inhalation. In a separate experiment HF laden air was drawn through the upper respiratory tract of the $r$ at while room air was respired through an endotrachael tube. Analysis of the fluoride concentration in air drawn into and leaving the upper respiratory tract indicated that greater than 99.98 of airborne HF was removed during passage through that site. A dose-dependent increase in plasma ionic fluoride concentration occurred after upper respiratory tract HF exposure providing strong evidence that tluoride is absorbed 
systemically from that site. The plasma ionic fluoride concentration after upper respiratory tract exposure was of sufficient magnitude to account for the plasma fluoride concentrations observed intact nose-only exposed rats. In summary, inhaled $\mathrm{HF}$ is near completely deposited in the upper respiratory tract and is absorbed systemically from that site. Two forms of fluoride are present in the plasma of $\mathrm{HF}$. exposed rats, one ionic in nature, the other a fluoride specie(s) which does not respond to the fluoride ion sensitive electrode. 
TITLE PAGE

i

VITA

ii

ACKNOWLEDGEMENTS

ABSTRACT iv

TABLE OF CONTENTS Vii

LIST OF TABLES viii

LIST OF FIGURES Xiii

INTRODUCTION 1

METHODS AND MATERIALS 19

Animal Care and Sacrifice Procedure 19

Metabolic Studies 21

Exposure Conditions $\quad 22$

Experimental Protocols $\quad 25$

Statistics 39

Fluoride Analysis 40

$\triangle \mathrm{F}$ Characterization $\quad 47$

RESULTS AND COMMENTS $\quad 50$

I. Whole Body Exposures 50

A. Preliminary Experiments $\quad 50$

B. Dose-Response Experiment 65

C. HF Rctention Experiment 101

D. NaF Retention Experiment 133

II. Nose-Only and Non-Inhalation Exposures 148

A. Intravenous NaF Infusion 148

B. HF Retention-Normal F Diet 156

C. Fluoride Deplelion Experiment 166

D. Fluoride Injection 178

E. Upper Respiratory Tract Exposure 183

F. HF Retention in Fluoride Depleted Rats 196

G. Control Data 218

$\begin{array}{ll}\text { DISCUSS ION } & 223\end{array}$

$\begin{array}{ll}\text { SUMMARY } & 377\end{array}$

BIBLIOGRAPHY 
$1 \quad$ LC50 OF HF IN SEVERAL SPECIES

2 EXPERTMENTAL PARAMETERS

3 EXPERIMENTS PERFORMED 17

4 TOTAL AND IONIC AIRBORNE FLUORIDE CONCENTRATIONS 24

5 HF REGULATOR PRESSURE AND CHAMBER AIRBORNE FLUORIDE $\begin{array}{ll}\text { CNCENTRATIONS } & 29\end{array}$

6 PULMONARY AND RENAL EFFECTS OF EXPOSURE TO $55 \mathrm{mgF} / \mathrm{m}^{3} \mathrm{HF}$ FOR 6 HOURS

7 MEASURED FLUORIDE CONCENTRATIONS IN SOFT TISSUES OF RATS EXPOSED TO $55 \mathrm{mg} \mathrm{F} / \mathrm{m}^{3}$ HF FOR 6 HOURS

$8 \triangle F$ CONCENTRATIONS IN SOFT TISSUES EXPOSED TO $55 \mathrm{mg} \mathrm{F} / \mathrm{m}^{3} \mathrm{HF}$ FOR 6 HOURS

9 PULMONARY AND RENAL EFFECTS OF EXPOSURE TO $380 \mathrm{mgF} / \mathrm{m}^{3} \mathrm{HF}$ FOR 2 HOURS

10 MEASURED FLUORIDE CONCENTRATIONS IN SOFT TISSUES OF RATS EXPOSED TO $380 \mathrm{mg} \mathrm{F} / \mathrm{m}^{3}$ HF FOR 2 HOURS

11 $\triangle F$ CONCENTRATIONS IN SOFT TISSUES OF RATS EXPOSED TO $380 \mathrm{mg} \mathrm{F} / \mathrm{m}^{3}$ FOR 2 HOURS

12 CHARACTERIZATION OF $\triangle F$ IN SOFT TISSUES OF RATS EXPOSED TO $380 \mathrm{mg} \mathrm{F} / \mathrm{m}^{3}$ FOR 2 HOURS

13 PULMONARY EFFECTS OF EXPOSURE TO $11,27,72,116,148$ OR $179 \mathrm{mg} \mathrm{F} / \mathrm{m}^{3} \mathrm{HF}$ FOR 6 HOURS

14 RENAL EFFECTS OF EXPOSURE TO 11, 27, 72, 116, 148 OR $179 \mathrm{mg} \mathrm{F} / \mathrm{m}^{3} \mathrm{HF}$ FOR 6 HOURS

15 MFA.ATRFD ELUORIDE CONCENTRATIONS IN SOFT TISSUES OF RATS EXPOSED TO $11,27,72,116,148$ OR $179 \mathrm{mg} \mathrm{F} / \mathrm{m}^{3} \mathrm{HF}$ FOR 6 HOURS

$16 \triangle F$ CONCENTRATIONS IN SOFT TISSUES OF RATS EXPOSED TO $11,27,72,116,148$ or $179 \mathrm{mg} \mathrm{F} / \mathrm{m}^{3} \mathrm{HF}$ FOR 6 HOURS

17 PULMONARY AND RENAL EFFECTS IN CHARLES RIVER RATS OF EXPOSURE TO 26,54 , Or $84 \mathrm{mg} \mathrm{F} / \mathrm{m}^{3} \mathrm{HF}$ FOR 6 HOURS 
18 MEASURED FLUORIDE CONCENTRATIONS IN SOFT TISSUES OF CHARLES RIVER RATS EXPOSED TO 26,54 or $84 \mathrm{mg} \mathrm{F} / \mathrm{m}^{3} \mathrm{HF}$ FOR 6 HOURS

$19 \triangle F$ CONCENTRATIONS IN SOFT TISSUES OF CHARLES RIVER RATS EXPOSED TO 26,54 OR $84 \mathrm{mg} \mathrm{F} / \mathrm{m}^{3} \mathrm{HF}$ FOR 6 HOURS

20 CHARACTERIZATION OF $\triangle F$ IN PLASMA OF CHARLES RIVER RATS EXPOSED TO $84 \mathrm{mg} \mathrm{F} / \mathrm{m}^{3}$ FOR 6 HOURS - CALCIUM PHOSPHATE ADSORPTION

21 PULMONARY AND RENAL EFFECTS OF EXPOSURE TO $111 \mathrm{mg} \mathrm{F} / \mathrm{m}^{3}$ PLUS WATER VAPOR

22 MEASURED FLUORIDE CONCENTRATIONS IN SOFT TISSUES OF RATS EXPOSED TO $111 \mathrm{mg} \mathrm{F} / \mathrm{m}^{3}$ PLUS WATER VAPOR

$23 \triangle F$ CONCENTRATIONS IN SOFT TISSUES OF RATS EXPOSED TO $111 \mathrm{mg} \mathrm{F} / \mathrm{m}^{3}$ PLUS WATER VAPOR

24 PULMONARY EFFECTS FOLLOWING EXPOSURE TO $10.2 \mathrm{mg} \mathrm{F} / \mathrm{m}^{3} \mathrm{HF}$ FOR 6 HOURS

25 RENAL EFFECTS FOLLOWING EXPOSURE TO $10.2 \mathrm{mg} \mathrm{F} / \mathrm{m}^{3} \mathrm{HF}^{1} \quad 108$

26 MEASURED FLUORIDE CONCENTRATIONS IN SOFT TISSUES OF RATS SACRIFICED SERIALLY AFTER CONTROL EXPOSURE

27 MEASURED FLUORIDE CONCENTRATIONS IN RATS SACRIFICED SERIALLY AFTER EXPOSURE TO $10.2 \mathrm{mg} \mathrm{F} / \mathrm{m}^{3}$ HF FOR 6 HOURS

28 FLUORIDE RETENTION HALF-TIMES IN SOFT TISSUES OF RATS EXPOSED TO $10.2 \mathrm{mg} \mathrm{F} / \mathrm{m}^{3} \mathrm{HF}$ FחR 5 HOIRS

$29 \triangle F$ CONCENTRATION IN SOFT TISSUES OF RATS SACRIFICED SERIALLY AFTER EXPOSURE TO $10.2 \mathrm{mg} \mathrm{F} / \mathrm{m}^{3}$ HF FOR 6 HOURS 120

30 URINARY IONIC FLUORIDE EXCRETION AND TOTAL FECAL FLUORIDE CONCENTRATION AFTER EXPOSURE TO $10.2 \mathrm{mg} \mathrm{F} / \mathrm{m}^{3}$ FOR 6 HOURS

$31 \triangle F$ CONCENTRATION IN URINE AFTER EXPOSURE TO $10.2 \mathrm{mg} F / \mathrm{m}^{3}$ HF FOR 6 HOURS 
32 COMPARISON OF URINARY F EXCRETION AND FEMORAL FLUORIDE RETENTION

33 PULMONARY EFFECTS OF EXPOSURE TO $24 \mathrm{mg} \mathrm{F} / \mathrm{m}^{3} \mathrm{NaF}$ FOR 6 HOURS

34 RENAL EFFECTS OF EXPOSURE TO $24 \mathrm{mg} \mathrm{F} / \mathrm{m}^{3} \mathrm{NaF}$ FOR 6 HOURS \ 137

35 MEASURED FLUORIDE CONCENTRATION IN SOFT TISSUES OF RATS EXPOSED TO $24 \mathrm{mg} \mathrm{F} / \mathrm{m}^{3}$ NaF FOR 6 HOURS

$36 \triangle F$ CONCENTRATIONS IN SOFT TISSUES OF RATS EXPOSED

TO $24 \mathrm{mg} \mathrm{F} / \mathrm{m}^{3}$ NaF FOR 6 HOURS

37 FLUORIDE EXCRETION AND FEMORAL FLUORIDE CONTENT OF RATS FOLLOWING EXPOSURE TO $24 \mathrm{mg} \mathrm{F} / \mathrm{m}^{3}$ NaF FOR 6 HOURS

$38 \triangle F$ CONCENTRATION IN URINE AFTER EXPOSURE TO

$24 \mathrm{mg} \mathrm{F} / \mathrm{m}^{3}$ NaF FOR 6 HOURS

39 PULMONARY EFFECTS OF INTRAVENOUS INFUSION OF $10.8 \mu \mathrm{g} \mathrm{F} / \mathrm{min} \mathrm{NaF}$ FOR 1 HOUR

40 RENAL EFFECTS OF INTRAVENOUS INFUSION OF $10.8 \mu \mathrm{g} \mathrm{F} / \mathrm{min} \mathrm{NaF}$ FOR 1 HOUR

41 MEASURED FLUORIDE CONCENTRATIONS IN SOFT TISSUES OF RATS INFUSED WITH $10.8 \mu \mathrm{g} \mathrm{F} / \mathrm{min} \mathrm{NaF}$ FOR 1 HOUR

$42 \triangle F$ CONCENTRATIONS IN SOFT TISSUES OF RATS INFUSED INTRAVENOUSLY WITH $10.8 \mathrm{ug} \mathrm{F} / \mathrm{min} \mathrm{NaF}$

43 URINARY IONIC FLUORIDE EXCRETION, FECAL TOTAL FLUORIDE CONCENTRATION AND FEMORAL FLUORIDE CONTENT IN RATS INTRAVENOUSLY INFUSED WITH $10.8 \mu \mathrm{g} \mathrm{F} / \mathrm{min}$ NaF FOR I HOUR

44 PULMONARY EFFECTS OF NOSE-ONLY EXPOSURE TO $75 \mathrm{mg} / \mathrm{F}^{3}$ HF FOR 1 HOUR

45 RENAL EFFECTS OF NOSE-ONLY EXPOSURE TO $75 \mathrm{mg} \mathrm{F} / \mathrm{m}^{3} \mathrm{HF}$ FOR 1 HOUR

46 MEASURED FLUORIDE CONCENTRATIONS IN SOFT TISSUES OF RATS SACRIFICED 96 HOURS AFTER THE START OF NOSE-ONLY EXPOSURE TO $75 \mathrm{mg} \mathrm{F} / \mathrm{m}^{3} \mathrm{HF}$ FOR 1 HOUR 
$47 \triangle F$ CONCENTRATIONS IN SOFT TISSUES OF RATS SACRIFICED

96 HOURS AFTER THE START OF NOSE-ONLY EXPOSURE TO $75 \mathrm{mg} \mathrm{F} / \mathrm{m}^{3}$ HF FOR 1 HOUR

48 URINARY IONIC FLUORIDE EXCRETION, FECAL TOTAL FLUORIDE CONCENTRATION AND FEMORAL FLUORIDE CONTENT AFTER NOSE-ONLY EXPOSURE TO $75 \mathrm{mg} \mathrm{F} / \mathrm{m}^{3}$ FOR I HOUR

$49 \triangle F$ CONCENTRATION IN URINE AFTER NOSE-ONLY EXPOSURE TO

50 PULMONARY AND RENAL EFFECTS OF FLUORIDE DEPLETION

51 MEASURED FLUORIDE CONCENTRATIONS IN SOFT TISSUES OF RATS DURING FLUORIDE DERLETION

$52 \triangle F$ CONCENTRATIONS IN SOFT TISSUES OF RATS DURING FLUORIDE DEPLETION

$53 \triangle F$ CONCENTRATION IN URINE OF RATS DURING FLUORIDE DEP LETION

54 URINARY IONIC FLUORIDE EXCRETION AND FECAL TOTAL FLUORIDE CONCENTRATION IN PARTIALLY FLUORIDE DEPLETED RATS AFTER INTRATRACHEAL INSTILLATION OF $200 \mu \mathrm{g} F$ AS NaF

55 RENAL EFFECTS IN FLUORIDE DEPLETED RATS OF INTRATRACHEAL OR INTRAPERITONEAL INJECTION OF $200 \mu \mathrm{g} F$ AS NaF

56 URINARY IONIC FLUORIDE EXCRETION IN FLUORIDE DEPLETED RATS INJECTED INTRATRACHEALLY OR INTRAPERITONEALLY WITH $200 \mu \mathrm{g} F$ AS NaF

57 URINARY IONIC FLUORIDE EXCRETION IN NORMAI, F RATS AND FLUORIDE DEPLETED RATS INJECTED INTRAPERITONEALLY WITH $200 \mu \mathrm{g} F$ AS NaF

58 TOTAL FECAL FLUORIDE EXCRETION IN FLUORIDE DEPLETED RATS INJECTED WITH $200 \mu \mathrm{g}$ F AS NaF

59 CONCENTRATION OF HF IN CHAMBER AIR AND TRACHEAL AIR OF UPPER RESPIRATORY TRACT (U.R.T.) EXPOSED RATS

60 COMPARISON OF FLUORIDE DRAWN THROUGH UPPER RESPIRATORY TRACT (U.R.T.) AND ESTIMATED ABSORBED FLUORIDE BURDEN AT END OF EXPOSURE 
61 EXPOSURE CONDITIONS FOR FLUORIDE DEPLETED RAT HF RETENTION EXPERIMENT

62 PULMONARY EFFECTS OF I HOUR NOSE-ONLY EXPOSURE TO APPROXIMATELY $63 \mathrm{mg} \mathrm{F} / \mathrm{m}^{3} \mathrm{HF}$

63 RENAL EFFECTS OF 1 HOUR NOSE-ONLY EXPOSURE TO APPROXIMATELY $63 \mathrm{mg} \mathrm{F} / \mathrm{m}^{3}$ HF

64 MEASURED FLUORIDE CONCENTRATIONS IN SOFT TISSUES OF RATS AFTER NOSE-ONLY EXPOSURE TO APPROXIMATELY $63 \mathrm{mg} \mathrm{F} / \mathrm{m}^{3} \mathrm{HF}$ FOR 1 HOUR

$65 \triangle F$ CONCENTRATIONS IN SOFT TISSUES OF RATS AFTER NOSE-ONLY EXPOSURE TO APPROXIMATELY $63 \mathrm{mg} \mathrm{F} / \mathrm{m}^{3} \mathrm{HF}$ FOR 1 HOUR

66 URINARY IONIC FLUORIDE EXCRETION, FECAL TOTAL FLUORIDE CONCENTRATION AND FEMORAL FLUORIDE CONTENT FOLLOWING NOSE-ONLY EXPOSURE TO $63 \mathrm{mg} \mathrm{F} / \mathrm{m}^{3}$ HF FOR 1 HOUR

$67 \triangle F$ CONCENTRATION IN URINE OF RATS AFTER NOSE-ONLY EXPOSURE TO APPROXIMATELY $63 \mathrm{mg} \mathrm{F} / \mathrm{m}^{3}$ HF FOR 1 HOUR

68 FLUORIDE CONCENTRATIONS IN UPPER RESPIRATORY TRACT RINSES OF RATS EXPOSED TO APPROXIMATELY $63 \mathrm{mg} \mathrm{F} / \mathrm{m}^{3}$ HF FOR I HOUR

69 FLUORIDE ON FUR OF RATS AFTER NOSE-ONLY EXPOSURE TO APPROXIMATELY $63 \mathrm{mg} \mathrm{F} / \mathrm{m}^{3}$ HF FOR 1 HOUR

70 FLUORIDE CONCENTRATION IN SOFT TISSUES OF CONTROL RATS

$71 \triangle F$ CONCENTRATIONS IN URINE OF CONTROL RATS 
LIST OF FIGURES

Figure

Page

1 THE 28 LITER GLASS BATTERY JAR INHALATION CHAMBER

26

2 GAS FLOW VERSUS HF REGULATOR PRESSURE

27

3 SCHEMATIC DIAGRAM OF UPPER RESPIRATORY TRACT EXPOSURE SYSTEM

36

4 MEASURED AIRBORNE FLUORIDE CONCENTRATION VERSUS

51 EXPOSURE TIME FOR THE $55 \mathrm{mg} \mathrm{F} / \mathrm{m}^{3}$ HF EXPOSURE

5 MEASURE AIRBORNE FLUORIDE CONCENTRATION VERSUS EXPOSURE TIME FOR THE $380 \mathrm{mg} \mathrm{F} / \mathrm{m}^{3}$ HF EXPOSURE

6 MEASURED AIRBORNE FLUORIDE CONCENTRATION VERSUS EXPOSURE TIME FOR THE 11, 27, 116, 148, and 179 $\mathrm{mg} \mathrm{F} / \mathrm{m}^{3}$ HF DOSE-RESPONSE EXPOSURES TO BLUE SPRUCE RATS

7 LIGHT MICROGRAPH OF LUNG FROM A CONTROL AND

71 HF EXPOSED RAT

8 LIGHT MICROGRAPH OF KIDNEY FROM A CONTROL AND HF EXPOSED RAT

9 BUN VERSUS LOG PLASMA IONIC FLUORIDE CONCENTRATION

10 LUNG AND KIDNEY IONIC FLUORIDE CONCENTRATION

VERSUS PLASMA IONIC FLUORIDE CONCENTRATION

11 PLASMA $\triangle F$ OONCENTRATION VERSUS LOG PLASMA TOTAL FLUORIDE CONCENTRATION IN BLUE SPRUCE RATS EXPOSED TO HF GENERATED BY THE COMPRESSED GAS TECHNIQUE

12 MEASURED AIRBORNE FLUORIDE CONCENTRATION VERSUS EXPOSURE TIME FOR THE 26,54 and $84 \mathrm{mg} \mathrm{F} / \mathrm{m}^{3} \mathrm{HF}$ EXPOSURES TO CHARLES RIVER RATS

13 SEPHADEX G-25 ELUTION PROFILE OF PLASMA OF CHARLES RIVER RATS EXPOSED TO $84 \mathrm{mg} \mathrm{F} / \mathrm{m}^{3}$ GENERATED BY THE AQUEOUS SYSTEM

14 MEAEURED $\triangle$ IRBORNE BLUDRIDE MNCFNTRATION VERSUS EXPOSURE TIME FOR THE $111 \mathrm{mg} \mathrm{F} / \mathrm{m}^{3}$ HF PLUS WATER VAPOR HF EXPOSURE

15 MEASURED AIRBORNE FLUORIDE CONCENTRATION VERSUS EXPOSURE TIME FOR THE $10.2 \mathrm{mg} \mathrm{F} / \mathrm{m}^{3}$ HF RETENTION EXPERIMENT EXPOSURE 
16 MEAN LUNG, PLASMA AND KIDNEY IONIC FLUORIDE

17 LOG OF THE MEAN LUNG IONIC FLUORIDE CONCENTRATION FOLLOWING EXPOSURE TO $10.2 \mathrm{mg} \mathrm{F} / \mathrm{m}^{3}$ HF VERSUS POSTEXPOSURE TIME

18 FEMORAL FLUORIDE CONTENT OF CONTROL AND $10.2 \mathrm{mg} \mathrm{F} / \mathrm{m}^{3}$ HF EXPOSED RATS VERSUS POSTEXPOSURE TIME

19 LOG OF THE MEAN DAILY URINARY IONIC FLUORIDE EXCRETION FOLLOWING EXPOSURE TO $10.2 \mathrm{mg} \mathrm{F} / \mathrm{m}^{3} \mathrm{HF}$ VERSUS POSTEXPOSURE TIME

20 LOG PROBABIIITY PLOT OF NAF DUST COLLECTED ON EACH STAGE OF MERCER IMPACTOR

21 URINE VOLUME AND SPECIFIC GRAVITY FOLLOWING EXPOSURE TO $24 \mathrm{mg} \mathrm{F} / \mathrm{m}^{3} \mathrm{NaF}$ VERSUS POSTEXPOSURE TIME

22 DAILY URINARY IONIC FLUORIDE EXCRETION OF FLUORIDE DEPLETED RATS VERSUS TIME ON LOW FLUORIDE DIET

23 LOG OF THE MEAN DAILY IONIC FLUORIDE EXCRETION OF FLUORIDE DEPLETED RATS VERSUS TIME ON LOW FLUORIDE DIET

24 MEAN FECAL TOTAL FLUORIDE CONCENTRATION OF FLUORIDE 176 DEPLETED RATS VERSUS TIME ON LOW FLUORIDE DIET

25 EXPERIMENTAL PROTOCOL FOR UPPER RESPIRATORY TRACT EXPOSURE

26 PLASMA IONIC FLUORIDE CONCENTRATION OF UPPER RESPIRATORY TRACT EXPOSED RATS VERSUS HF EXPOSURE CONCENTRATION

27 TOTAL FEMORAL FLUORIDE CONTENT OF CONTROL RATS VERSUS 221 BODY WEIGHT 


\section{INTRODUCTION}

The presence of hydrogen fluoride in the atmosphere of venus (Mueller, 1968) points out the possibility that a fraction of the HF present in the earth's atmosphere may be derived from natural sources. Volcanic activity is one such natural source of HF (Smith and Hodge, 1979). There can be no doubt however, that man has added significant amounts of HF to his environment.

Hydrogen fluoride is a highly corrosive compound with a boiling point of $19.5^{\circ} \mathrm{C}$ and thus can exist in the gaseous or liquid state at temperatures near room temperature. In the gaseous state HF may polymerize to form compounds up to $\mathrm{H}_{6} \mathrm{~F}_{6}$, however, as discussed by Leech (1956), at the temperatures and partial pressures of $\mathrm{HF}$ encountered in the experiments to be described in this thesis essentially no polymerization occurs. Hydrogen fluoride is miscible at all concentrations with water; gaseous hydrogen fluoride fumes in moist air (NIOSH, 1976). In aqueous solution hydrogen fluoride is a weak acid $\left(k_{A}=1 \times 10^{-3}\right)$. Perhaps the most widely known property of hydrofluoric acid is that it dissolves glass. Commercially hydrofluoric acid is used in glass etching processes.

The National Institute of Occupational Safety and Health (1976) estimates that 22,000 workers are potentially exposed to $\mathrm{HF}$ in the United States. Hydrogen fluoride is used in the production of cryolite in the aluminum industry and in the manufacture of 
fluorocarbon compounds. These two uses account for approximately 808 of the 400,000 tons of $\mathrm{HF}$ consumed in the United states in 1974 (NIOSH, 1976). Considerable amounts of gaseous fluorides, principally $\mathrm{HF}$ and $\mathrm{SiF}_{4}$ are released during the production of phosphoric acid and phosphate fertilizers. In this process dry phosphate rock, which contains 3.5-4.28 fluoride, is treated with acid, thereby converting the fluoride to volatile forms. The HF formed in this process may react with the silica in the rock to form $\mathrm{SiF}_{4}$ (Rye, 1961). NIOSH (1976) recommends a standard of 2.5 $\mathrm{mg} / \mathrm{m}^{3} \mathrm{~F}$ as HF for up to a 10 hour workday and a 40 hour work week. Hodge and Smith (1977) have recently reviewed the literature concerning occupational exposure to fluoride. In the workplace atmosphere numerous other fluorocompounds, either particulate or gaseous, are always present with HF. Consequently epidemiologic studies do not discriminate the effects of $\mathrm{HF}$ from those of other fluorocompounds. In general, these studies have revealed no toxic effects except in the bone following chronic exposure to atmospheres containing less than $6 \mathrm{mg} \mathrm{F} / \mathrm{m}^{3}$. Fluoride accumulates in the bone and may, if enough of this ion is deposited in this tissue, lead to crippling fluorosis. This condition is characterized by osteosclerosis, exostoses of bone and calcification of ligaments (Hodge and Smith, 1977). Many years of exposure are required for this condition to develop. In all epidemioligic studies in which it was measured, urinary fluoride excretion was increased by occupational exposure to fluoride 
containing atmospheres indicating that exposed individuals absorb significant amounts of fluoride. Machle and Evans (1940) reported no abnormal chest or bone radiographic or hematologic findings in men exposed to $\mathrm{HF}$ and $\mathrm{CaF}_{2}$ in the manufacture of $\mathrm{HF}$. Airborne fluoride levels were occasionally as high as $21 \mathrm{mg} \mathrm{F} / \mathrm{m}^{3}$. Rye (1961) studied individuals exposed to fluorides involved in a rock phosphate operation. He did not detect a significant increase in any particular type of gastrointestinal or respiratory complaint in exposed workers. Airborne fluoride concentrations were maintained below $3 \mathrm{mg} \mathrm{F} / \mathrm{m}^{3}$. Derryberry, et al. (1963) investigated the health of 74 men exposed to fluoride gases and dusts in a phosphate fertilizer manufacturing plant. Airborne fluoride concentrations were calculated to be less than $4.5 \mathrm{mg} \mathrm{F} / \mathrm{m}^{3}$. Clinical

examination revealed no increased incidence of positive physical findings in the respiratory, gastrointestinal, cardiovascular, genltourinary or musculoskeletal systems of these fluoride exposed individuals compared to a control group matched for age, sex and socioeconomic class. Medical histories revealed an increased incidence of pneumonia, pleurisy and influenza in the exposed group. Derryberry, et al. reported "minimal or questionable degrees of increased bone density" measured in chest and pelvic radiographs, but the effects did not correlate with fluoride exposure as measured by length of employment or urinary fluoride levels. These authors also reported a slight increase $(p<0.10$ compared to control) in incidence of albuminuria. Other clinical 
studies have not seen this effect. In over 41,000 urine samples collected from workers in the aluminum industry no correlation between increased incidence of proteinuria and urinary fluoride was seen (Dinman, et al., 1976). Though increased bone density was detected in workers exposed to as much as $6 \mathrm{mg} \mathrm{F} / \mathrm{m}^{3}$ in an aluminum smelter, no increase in gastrointestinal or genitourinary disease or in chronic obstructive pulmonary disease was detected (Kaltreider, et al., 1972). Diagnosis of chronic obstructive pulmonary disease was based on chest radiographs and forced vital capacities.

Slight irritation of the face, nose and eyes was experienced by men exposed to $1.1-3.7 \mathrm{mg} \mathrm{F} / \mathrm{m}^{3} \mathrm{HF}$ in an investigation of the urinary fluoride excretion after HF exposure (Largent, 1961). At $26 \mathrm{mg} / \mathrm{m}^{3} \mathrm{HF}\left(25 \mathrm{mg} \mathrm{F} / \mathrm{m}^{3}\right)$ mild irritation of the eyes, nose and larger airways is reported (Machle, et al., 1934). At $48 \mathrm{mg} \mathrm{F} / \mathrm{m}^{3}$ there is a marked conjuntival and nasal irritation and tickling and discomfort in the larger airways upon inspiration. A concentration of $95 \mathrm{mg} \mathrm{F} / \mathrm{m}^{3}$ was the highest that would be tolerated by humans for 1 minute. At this concentration the effects were similar to those reported for $48 \mathrm{mg} \mathrm{F} / \mathrm{m}^{3} \mathrm{HF}$. Largent (1961) reported exposure to $420-850 \mathrm{mg} \mathrm{F} / \mathrm{m}^{3} \mathrm{HF}$ causes extreme pain in the eyes, nose, mouth, pharynx and the upper chest of humans. This high concentration also causes watery discharges from the eyes and nose, coughing, gasping and laryngospasm. Two humans exposed to HF when a 2 liter bottle of hydrofluoric acid exploded died within 10 hours 
of the accident (Greendyke and Hodge, 1964). In both men severe pulmonary edema was thought to be the cause of death. Blood fluoride concentrations at the time of death were 3 and $4 \mu \mathrm{g} / \mathrm{ml}$ in these men (normal level less than $0.1 \mu \mathrm{g} / \mathrm{ml}$ ).

Inhaled HF is thought to be rapidly absorbed and excreted by the human. Rye (1961) investigated the urinary fluoride excretion in humans exposed to atmospheric fluorides at a rock phosphate plant. The proportions of gaseous and particulate fluoride was not given. Peak urinary fluoride excretion (fluoride excreted per two hour collection period) occurred 2-4 hours after the end of exposure. Urinary fluoride concentration did not return to control levels until 3 days following the exposure. Collings, et al. (1951) investigated the fluoride excretion in two subjects exposed to an industrial environment containing fluoride "principally in the gaseous state, in the form of $\mathrm{HF}$ and $\mathrm{SiF}_{4}$ " for 8 hours. Particulate fluoride constituted less than $5 \%$ of the total airborne fluoride. Peak urinary fluoride excretion (fluoride excreted per 2 hour collection period) occurred 2-4 hours after the end of exposure. The time weighted average fluoride concentration for the exposure was $3.3 \mathrm{mg} \mathrm{F} / \mathrm{m}^{3}$. Urinary fluoride excretion was elevated over control levels during the day of the exposure and during the succeeding day. Of the total excess fluoride excreted by the two subjects ( $9.5 \mathrm{mg}$ and $8.6 \mathrm{mg}$ ) 8 and $15 \%$ was excreted during the day following exposure. If a ventilation rate of $81 / \mathrm{min}$ is assumed then it is estimated that each subject inhaled 
$13 \mathrm{mg}$ fluoride. Largent (1961) studied the fluoride excretion in 5 subjects exposed to $\mathrm{HF}$ at concentrations ranging from $1.1-3.8$ $\mathrm{mg} \mathrm{F} / \mathrm{m}^{3}$ for 6 hours per day, 5 days per week for a total of 10-50 days. Largent stated that inhalation of HF caused a prompt increase in the urinary fluoride excretion. In summary, studies on man have shown that airborne fluorides may be rapdily absorbed when inhaled as evidenced by a prompt increase in urinary fluoride excretion. However, in only one study (Largent, 1961) was HF the sole source of airborne fluoride. In the other studies, the chemical nature of the airborne fluoride was poorly defined. Exposure to airborne HF produces repiratory tract irritation and can cause death presumably due to pulmonary edema, if the exposure is severe enough. No consistent effect of chronic exposure to low levels of airborne fluoride is evident in any tissue except bone. There have been several investigations of the mortality in animals following exposure to airborne HF. The results of these studies are summarized in Table 1. In these studies mortality was monitored for 1-4 weeks following exposure but usually occurred within 24 hours. As can be seen high concentrations compared to the recommended standard of $2.5 \mathrm{mg} \mathrm{F} / \mathrm{m}^{3}$ are necessary to cause mortality. As the length of exposure increases the LC50 decreases. Some species differences are also evident, viz. the mouse appears to be more sensitive to $\mathrm{HF}$ than the rat. In each of these studies it was reported that $\mathrm{HF}$ induced nasal irritation. This irritation was shown by mucoid discharge from the nose, 


\section{TABLE 1}

LC50 OF HF IN SEVERAL SPECIES

\begin{tabular}{|c|c|c|c|}
\hline $\begin{array}{l}\text { Exposure } \\
\text { time }\end{array}$ & $\begin{array}{c}\text { LC50 } \\
\left(\mathrm{mg} \mathrm{F} / \mathrm{m}^{3}\right)\end{array}$ & Species & Reference \\
\hline 5 minute & 5,000 & mouse & Di Pasquale and Davis (1971) \\
\hline 5 minute & 14,400 & rat & $"$ \\
\hline 5 minute & 4,060 & rat & Rosenholtz, et al. (1963) \\
\hline 15 minute & 2,200 & rat & $"$ \\
\hline 30 minute & 1,670 & rat & $"$ \\
\hline 60 minute & 1,070 & rat & $"$ \\
\hline 60 minute & 1,100 & rat & Woh 1slage1, et al. (1976) \\
\hline 60 minute & 270 & mouse & $"$ \\
\hline
\end{tabular}


sneezing, pawing at the nose and/or nasal pathology. Pulmonary damage was a common finding after these HF exposures. Pulmonary edema and hemmorrhage occurred in the rabbit and guinea pig (Machle, et al., 1934), and the rat and mouse (Di Pasquale and Davis, 1971; Wohlslagel, et al., 1976) after these exposures. Rosenholtz, et al. (1963) observed mucosal and submucosal necrosis of the anterior portion of the nasal passages in the rat after exposure to HF but made no mention of pulmonary damage. These authors also observed proximal tubular necrosis of the kidney in these exposed rats. Similar renal injury has been reported to occur in the rat after acute sodium fluoride intoxication (Taylor, et al., 1961).

Pulmonary and renal injury have been observed in several species after chronic HF exposure. Machle and Kitzmiller (1935) exposed rabbits and guinea pigs to $14.4 \mathrm{mg} \mathrm{F} / \mathrm{m}^{3} \mathrm{HF}, 6-7$ hours per day, 5 days per week for a total of 309 exposure hours ( 50 exposure days). Pulmonary damage was evident in some guinea pigs (1 ung hemorrhage and atelectasis) and some rabbits (inflammation of alveolar walls). Pulmonary edema and/or hemorrhage was present in the dog, rat and rabbit exposed to $25 \mathrm{mg} / \mathrm{m}^{3} \mathrm{HF}\left(24 \mathrm{mg} F / \mathrm{m}^{3}\right) 6$ hours per day, 6 days per week for a total of 30 exposure days (Stokinger, 1949). This exposure regimen produced 1008 mortality in the rat and mouse. Renal cortical degeneration was observed in the kidney of all rats exposed to this regimen. No mortality or pathologic effects were observed in the same species after exposure to $7 \mathrm{mg} \mathrm{F} / \mathrm{ul}^{3} \mathrm{HF}$ by a similar regimen (Stokinger, 1949). 
In only a few instances has there been an attempt to measure the fluoride burdens in animals after the exposure to HF. Smith and Gardner (1949) measured the blood fluoride concentration in rabbits immediately after 1 to 5 days ( 6 hours per day) exposure to $29 \mathrm{mg} / \mathrm{m}^{3} \mathrm{HF}\left(28 \mathrm{mg} \mathrm{F} / \mathrm{m}^{3}\right)$. The blood fluoride concentration averaged $0.75 \mu \mathrm{g} / \mathrm{ml}$ (control $0.12 \mu \mathrm{g} / \mathrm{ml}$ ) and did not appear to increase with successive day of exposure, however, there was a lot of scatter in the data. Blood fluoride levels in rabbits sacrificed from 1-4 days postexposure ranged from 0.18 to 0.48 $\mu \mathrm{g} / \mathrm{ml}$. Machle and Scott (1935) determined bone fluoride content in rabbits sacrificed 9-15 months after exposure to varying levels of $\mathrm{HF}$. The exposures ranged from chronic $\left(14.4 \mathrm{mg} \mathrm{F} / \mathrm{m}^{3} \times 309\right.$ hours) to acute (1000 $\mathrm{mg} \mathrm{F} / \mathrm{m}^{3} \times 1$ hour). When the rabbits were separated into 4 groups using the HF concentration times the length of exposure (C $\times \mathrm{T})$ as a measure of the dose, a dose-dependent increase in bone fluoride content was evident. Bone fluoride content ranged from 3-fold higher than control levels in the lowest C $\times$ T exposed group to 13-fold higher in the highest $C \times T$ exposed group. Femoral fluoride content was measured in rats sacrificed serially during exposure to $25 \mathrm{mg} / \mathrm{m}^{3} \mathrm{HF}\left(24 \mathrm{mg} \mathrm{F} / \mathrm{m}^{3}\right) 6$ hours per day 6 days per week for a total of 30 exposed days (stokinger, 1949). The femoral fluoride concentration in exposed rats was at least 5 times higher than control levels and increased with increasing time of exposure. 
Skeletal deposition of fluoride has been shown to occur after intoxication with other fluorocompounds (Smith, 1966). Since HF is a weak acid complete ionization would be expected at physiologic pH. Thus, the distribution of fluoride after HF exposure would be expected to be similar to that after administration of ionic fluoride. Smith (1966) has reviewed the voluminous literature concerning the metabolism of fluoride.

Absorption of fluoride after ingestion of soluble fluoride salts is quite rapid. Wallace-Durbin (1954) reported absorption of an ingested dose of $\mathrm{NaF}$ to be $75 \%$ complete in 1 hour and 908 complete within 9 hours. Peak plasma fluoride concentrations occurred shortly after ingestion. After ingestion of NaF peak plasma fluoride concentrations occur within 30 minutes in the rabbit (Hall, et al., 1976), in 90 minutes or less in the rat (de Lopez, et al., 1976) and within 1 hour in the human (Hennon, et al., 1969).

A large fraction, approximately 508, of the fluoride absorbed into the blood stream deposits rapidly in the skeleton. Two minutes after intravenous $\mathrm{Na}^{18} \mathrm{~F}$ injection significant amounts of fluoride were detected by autoradiographic techinques in the skeleton of the mouse and rat (Ericcson and Ullberg, 1958). In another study (Wallace-Durbin, 1954) 338 and $56 \%$ of an intravenous dose of fluoride (as $\mathrm{NaF}$ ) was accounted for in the skeleton of the rat 15 minutes and $I$ hour after injection. Savchuck and Armstrong (1951) reported a retention of 428 of the absorbed fluoride during 
a 60 day feeding study in the rat. Over the course of a 20 week feeding study approximately $58 \%$ of the absorbed fluoride was found to be retained by the rat by Wadhwani (1953). Once deposited in the bone fluoride is removed slowly. In rats sacrificed 150 days after the termination of a 60 day feeding study the fluoride content of the humeri averaged $85 \%$ of that present in that site at the end of the feeding period (Savchuck and Armstrong, 1951).

Fluoride appears to accumulate only in calcified tissue. Smith, et al (1960) measured the fluoride concentration in heart, liver, lung, kidney and spleen obtained at autopsy from human subjects living in communities with differing amounts of fluoride in their water supplies. In none of these tissues was there any evidence of accumulation of fluoride. In the rat, the concentration of fluoride in all soft tissues analyzed except kidney was found to be less than or equal to the fluoride concentration in plasma at several times up to 9 hours after intravenous administration of NaF (Carlson, et al., 1960c; Wallace-Dur bin, 1954) .

Fluoride is rapidly excreted into the urine. In humans peak urinary fluoride concentrations occur between 1 and 2 hours after ingestion of NaF (2ipkin and Leone, 1970; Hennon, et al., 1969). Wallace-Durbin found 318 of an intravenous dose of fluoride (as NaF) to be excreted in the urine within 9 hours. Humans excreted a mean of 548 of an oral dose of fluoride (as NaF) in 24 hours (Zipkin and Leone, 1970). By 24 hours after ingestion the urinary fluoride excretion had returned to control levels in these individuals. A 
mean urinary excretion of 47.68 of an ingested fluoride dose occurred within 24 hours in another study (Hennon, et al., 1969). Over the course of a 20 week feeding study $\left(2 \mathrm{mg} \mathrm{F}^{-}\right.$as NaF p.o. per day) 428 of the administered dose was excreted in the urine by the rat (Wadhwani, 1953). The recovery of fluoride in this study was 998 . Very little fluoride was found in the soft tissues of these animals while large concentrations were present in bone. In sumary, the absorption, distribution and excretion of fluoride appears to be similar in animals and man. After ingestion of NaF, fluoride is rapidly absorbed. A large fraction of the absorbed dose deposits in the skeleton, a site from which it is slowly removed. The remaining fraction is excreted in the urine. There appears to be no accumulation of fluoride in soft tissues. Thus, quantification of the skeletal fluoride deposition and/or urinary fluoride excretion may provide a good estimate of the absorbed fluoride dose if it were unknown.

The effects of HF in animals and man are similar. Exposure to HF results in the absorption of significant amounts of fluoride in the body. This has been shown in animals by dose-dependent and time dependent increases in bone fluoride and in only one study by elevated plasma fluoride concentrations after exposure. In man significant elevations in urinary fluoride excretion occur following exposure to HF. The promptness of the increase in urinary fluoride excretion suggests that inhaled HF is rapidly absorbed. Exposure to high levels of HF causes death apparently 
due to respiratory insufficiency. In all species studied, including man, pulmonary edema and hemorrhage is a common finding after HF inhalation. Exposure to HF leads to renal damage in the rat; no clear cut effects of HF exposure on renal function have been demonstrated in man.

The experiments described in this thesis were performed to gain some quantitative information on the effects of inhaled HF. Considerable emphasis was placed on the absorption, distribution and excretion of fluoride as a result of $\mathrm{HF}$ exposure. Male Long Evans rats were used in every experiment. The parameters examined following each exposure are shown in Table 2. During every exposure airborne HF levels were determined by a modification of the N.I.O.S.H. (1976) recommended technique. The effects of $\mathrm{kF}$ on the lung were assessed by Iung histology and gravimetric analysis. The lung wet weight to dry weight ratio is perhaps the most sensitive measure of lung water content (Staub, 1974). After quantification of the lung water content following HF exposure it was hoped to study the pathogenesis of HF-induced pulmonary edema. However, the exposure regimens used in this investigation did not produce pulmonary edema in the rat.

Kidney histology, blood urea nitrogen, urine output, urine specific gravity and urinary protein excretion were monitored to assess renal damage following $\mathrm{HF}$ exposure. The fluoride ion produces renal toxicity (Taylor, et al., 1961) and has been shown to induce a diuresis in the rat (Whitford and Taves, 1973). 
TABLE 2

EXPERIMENTAL PARAMETERS

I Experimental Conditions

II Effects of Exposure

A. Pulmonary Effects

B. Renal Effects

III Fluoride Retention and Excretion

A. Soft Tissue Fluoride Retention

1. Total and Ionic Fluoride Concentration

2. $\Delta \mathrm{F}$ Concentration

a. Characterization of $\Delta F$

B. Fluoride Excretion and Skeletal Deposition

1. Urinary $F$ Excretion

a. Ionic Fluoride Content

b. $\Delta F$ Concentration

2. Fecal Fluoride Concentration

3. Femoral Fluoride Concentration

c. Sources of Fluoride 
To investigate the distribution of fluoride after exposure to HF the fluoride concentration in the lung (the presumed site of entry), the plasma (as a measure of the systemic fluoride burden), the kidney (the site of fluoride excretion) and the femur (as a representative sample of the skeleton, the site of fluoride deposition) were measured. Since recent evidence suggests that all of the fluoride present in plasma is not ionic in nature (Taves, 1968a; Guy, et al., 1976; Ophang and Singer, 1977), both total and ionic fluoride concentrations were measured in the plasma, lung and kidney of $\mathrm{HF}$ exposed rats. Whole body exposure to $\mathrm{HF}$ resulted in dose-dependent increases in total fluoride concentration, ionic fluoride concentration and in the concentration of a non-ionic fluoride component(s) referred to in this thesis as the $\Delta F$ fraction. A few preliminary investigations on the nature of the $\Delta F$ fraction were also performed.

Fluoride excretion in urine and feces was also measured after HF exposure. Both ionic and total fluoride concentration in urine was determined. Total fecal concentration was determined. At the end of each experiment the fluoride excretion data, the femoral fluoride content, and the soft tissue fluoride concentrations were compared in an attempt to infer some information on the site of absorption, the rate of absorption and the sources of absorbed fluoride in the HF exposed rats.

In addition to whole body and nose-only HF exposures, several supportive experiments on the absorption, distribution and 
excretion of fluoride were performed. The experiments described in this thesis are listed in Table 3. In the first group of experiments rats were subjected to whole body exposure to $\mathrm{HF}$ or NaF. After completion of two preliminary range finding experiments a dose response experiment was performed in which groups of rats obtained from Blue Spruce Farms suppliers were exposed to one or another of 6 different concentrations of airborne HF. Due to an administrative error (not ours) several groups of rats obtained from Charles River Laboratories were also exposed to HF. In one experiment the effect of increased relative humidity on HF toxicity (Blue Spruce rats) was examined. A large group of rats was exposed to $\mathrm{HF}$ and sacrificed serially up to 42 days postexposure to investigate the retention of fluoride after a single exposure. To obtain baseline data for comparison to HF, rats were exposed to NaF dust.

The results of the whole body HF and NaF retention experiments suggested that considerable amounts of fluoride deposit on the fur during exposure and were then ingested due to preening activity. Therefore, it was decided to expose rats to $\mathrm{HF}$ by a regimen in which only the nose was in contact with HF atmospheres. These nose-only exposures were of 1 hour duration. To gain baseline data rats were subjected to intraveous infusion of fluoride (as NaF) for I hour. Then as a preliminary experiment to quantify the response to nose-only exposure, rats maintained on the normal purina chow diet were nose-only exposed to HF. This exposure regimen did not 
TABLE 3

\section{EXPERIMENTS PERFORMED}

I Whole Body Exposure

A. Preliminary Experiments

1. $55 \mathrm{mg} \mathrm{F} / \mathrm{m}^{3}$

2. $380 \mathrm{mg} \mathrm{F} / \mathrm{m}^{3}$

B. Dose-Response Experiment

1. Blue Spruce Rats

2. Charles River Rats

3. Effect of Water Vapor

C. HF Retention Experiment

D. NaF Retention Experiment

II Nose-Only and Non-inhalation Exposures

A. Intravenous $\mathrm{NaF}$ Infusion

B. HF Retention in Normal F Rats

C. Fluoride Depletion Experiment

D. Fluoride Injection

E. Upper Respiratory Tract Exposure

F. HF Retention in F Depleted Rats 
greatly increase urinary fluoride concentration over control levels. It was, therefore, decided to maintain rats on a low fluoride diet prior to HF exposure. Before this exposure was undertaken, the rate of fluoride depletion in untreated rats on low fluoride diet and the fluoride excretion of the fluoride depleted rat after fluoride injection were investigated. Next an experiment in which the upper respiratory tract of the rat was isolated was performed to determine the fractional deposition of inhaled HF in this site. In the final experiment fluoride depleted rats were sacrificed at various times after nose-only HF exposure to investigate the retention of fluoride after this exposure regimen. 


\section{METHODS AND MATERIALS}

Animal Care and Sacrifice procedure

Male Long Evans rats obtained from Blue Spruce Farms

(Altamount, NY) or Charles River Laboratories (Wilmington, MD) were used in all experiments and at all times were housed and maintained according to rules promulagated by the American Physiological Society. Rats from Blue Spruce Farms were used unless indicated otherwise. The rats were maintained on Purina rat chow (Ralston-Purina, St. Louis, MO; fluoride concentration 25-35 $\mu \mathrm{g} / \mathrm{g}$ ) and tap water (fluoride concentration $\mathrm{l} \mu \mathrm{g} / \mathrm{ml}$ ). Prior to some experiments rats were fed low fluoride diet (Teklad Test Diets, Madison, WI; fluoride concentration $0.7 \mu \mathrm{g} / \mathrm{g}$ ) and distilled water (fluoride concentration less than $0.01 \mu \mathrm{g} / \mathrm{ml}$ ). Those experiments in which rats were fed low $\mathrm{F}$ diet are specified in the text.

All animals were sacrificed by an intraperitoneal injection of approximately $100 \mathrm{mg} / \mathrm{kg}$ sodium pentobarbital (V. Pento, A.J.Buck and Son, Cockeysville, MD). Approximately $8 \mathrm{ml}$ of blood for analysis was removed by cardiac puncture with a heparinized syringe while the heart was still beating.

The trachea was then cut just below the larynx, and the lung and trachea removed from the thoracic cavity and trimmed free of excess tissue. In one $r$ at per sacrifice group following whole body exposure, the entire lung and trachea were fixed intact in $10 \%$ buffered formalin. These lungs were to be used for investigation 
of the zonal distribution of any pulmonary edema produced by $\mathrm{HF}$ inhalation. In all other rats the trachea and major bronchi were removed at their point of entrance into the lung parenchyma and the lung was weighed. Approximately one-half of the left lung was placed in a tared test tube to be dried to constant weight at $60-80^{\circ} \mathrm{C}$ for determination of lung. wet weight to dry weight ratio. A section taken from the central portion of the left lung was fixed in 108 buffered formal in and later embedded in paraffin, sectioned at $4 \mu \mathrm{m}$ and stained with hematoxylin and eosin ( $\mathrm{H}$ and E) for light microscopic examination. The remaining lung tissue was homogenized in approximately 3 volumes of double distilled water in a glass Ten Broeck homogenizer using 4 complete strokes. The homogenate was then transferred to a graduated glass cylinder with two rinses of double distilled water, the final homogenate concentration being 6-7 parts water to one part lung.

Each kidney was removed, decapsulated and weighed. One kidney was sliced in half longitudinally, one half being fixed in $10 \%$ buffered formalin and processed for light microscopy in the same manner as pulmonary tissue. The remaining renal tissue (1-1/2 kidneys) was homogenized in double distilled water by the same procedure as for the lung. The final tissue concentration of kidney homogenates was 5-6 parts water to 1 part kidney. The right femur was removed and scraped free of most excess tissue with a scalpel. Femurs were stored in a refrigerator until analyzed for fluoride content. Plasma obtained by centrifugation 
of whole blood, trachea and tissue homogenates were stored frozen in polystyrene test tubes until analyzed for fluoride content. Metabolic studies

In several experiments rats were housed in metabolism cages (Lab Products, Rochelle Park, NJ) after exposure to hydrogen fluoride. Urine was collected in cups containing thymol and mineral oil. At the termination of each collection period rats were voided manually and the cage funnel and urine cup removed and immediately replaced with new ones. After removal of feces each cage funnel below the cages was rinsed with $10 \mathrm{ml}$ double distilled water to ensure complete collection of urine. Urine volumes were recorded to the nearest $\mathrm{ml}$ and corrected for the rinse water volume. The urine volumes during short collection periods ( 7 hour periods) were determined by weight and specific gravity. Any urine contained in the bladder upon sacrifice was removed by syringe and added to the appropriate urine cup.

Urine specific gravity was determined with a hand refractometer (American Optical Model 10400 TS Meter, American Optical, Buffalo, NY) and corrected for the cage wash volume. Urinary protein content was determined by the method of Lowry as modified by Schlatz (1971). The concentrations of thymol present in urine samples did not interfere with this assay. Another indicator of kidney function, blood urea nitrogen, was determined in plasma samples by the method of Chaney and Marbach (1962). 


\section{Exposure Conditions}

Male Long Evans rats were exposed to gaseous hydrogen fluoride in either of several different exposure systems. These systems included whole-body exposure in a 281 glass battery jar inhalation chamber (pickle jar, Leach, 1963), a modified pickle jar inhalation chamber, a $1.8 \mathrm{~m}^{3}$ Rochester Chamber (Leach, et al., 1959), and a nose only exposure in a specially constructed nose only exposure chamber. Each exposure system is discussed in greater detail later. During every exposure airborne HF levels were monitored by a modification of the N.I.O.S.H. recommended technique (NIOSH, 1976). Chamber air samples were drawn through two midget impingers in series at a flow rate of $0.5 \mathrm{l} / \mathrm{min}$ for 2 minutes or $0.77 \mathrm{l} / \mathrm{min}$ for 1 minute. Each impinger contained $10 \mathrm{ml}$ TISAB rather than the NIOSH recommended $0.1 \mathrm{~N} \mathrm{NaOH}$ as the trapping agent). An $0.5 \mathrm{ml}$ aliquot of the first impinger fluid was added to $1.5 \mathrm{ml}$ TISAB and analyzed for ionic fluoride by the known addition technique to be described. Fresh TISAB was placed in the first impinger prior to each sample collection. Air samples were drawn at least every 30 minutes during 6 hour exposures and at 10 minute intervals during 1 hour exposure. Less than 0.18 of the fluoride collected in the first impinger was found in the second impinger indicating the high collection efficiency of TISAB in this air sampling system.

Hydrogen fluoride atmospheres were generated by two techniques: the aqueous system and the compressed gas system. The aqueous system consisted of two teflon bubblers placed in a $50^{\circ} \mathrm{C}$ 
water bath through which clean room air was fed. The first bubbler contained distilled water and served to humidify the air; the second bubbler contained 248 aqueous analytical grade hydrofluoric acid (J.T. Baker Chemical, Phillipsburg, NJ). Air flowing from the second bubbler was combined with diluting air in a mixing flask and fed into the chamber. Chamber airborne HF concentrations were controlled by varying the air flow through the bubblers, maximal flow rates being $4 \mathrm{l} / \mathrm{min}$. For exposure generated by the compressed gas technique the output of a tank containing $18 \mathrm{HF}$ in nitrogen (Matheson Gas Products, East Rutherford, NJ) was mixed with clean room air in $\frac{1}{4} n$ polyethylene tubing and fed into the chamber. Since total and ionic fluoride concentrations were to be determined in soft tissues of rats exposed to HF, both total and ionic fluoride concentrations were determined on several air samples withdrawn from chambers containing HF generated by either technique. These chamber air samples were collected in double distilled water. Water is also an efficient collecting agent of airborne HF. In addition, total and ionic fluoride concentrations were determined on diluted samples of the hydrofluoric acid solution used in the bubbler of the aqueous system. As can be seen, (Table 4) total and ionic fluoride concentrations in air samples and in bubbler fluid were identical within analytical error. Total and ionic fluoride concentrations in these samples were determined by the method to be described for plasma samples. 
TABLE 4

TOTAL AND IONIC AIRBORNE FLUORIDE CONCENTRATIONS

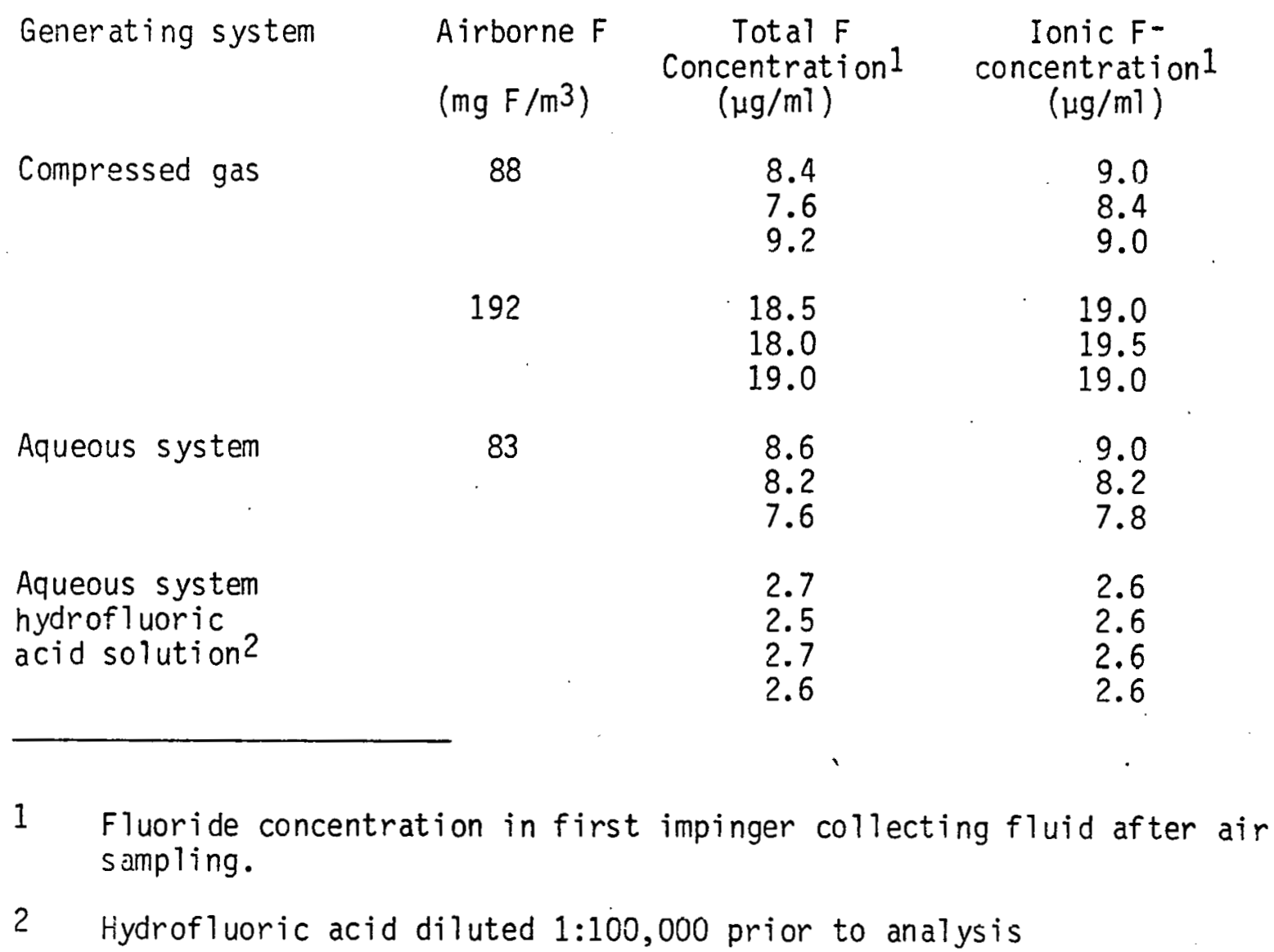




\section{Experimental: Protocols}

In the preliminary experiments rats were exposed to $\mathrm{HF}$ generated by the aqueous system for 6 hours in a 281 glass battery jar inhalation chamber (Figure 1). Total flow rates were measured with rotameters (F.W. Dwyer, Michigan City, IN) Rats were sacrificed immediately after exposure, 6 hours after the end of exposure or 24 hours after the start of exposure.

Because of the difficulties encountered in the generation and maintenance of HF atmospheres by the aqueous system it was decided to generate HF atmopsheres in the dose-response experiment by diluting the output of a tank containing $18 \mathrm{HF}$ in nitrogen (compressed gas technique). To help control the output of the HF tank an orifice made by drilling a hole in a teflon disc was placed in the outlet nozzle of the HF regulator. The orifice was calibrated by placing the nozzle containing the orifice on a tank of nitrogen and measuring the gas flow through the nozzle at several regulator pressures using a dry gas meter. As is shown in Figure 2, the flow is Iinearly related to regulator pressure. With one orifice the flows were excessively high, and, therefore, a second orifice was added to the system. This was accomplished by placing a second drilled disc in a polyethylene tube which was then attached to the nozzle. Flow plotted versus regulator pressure in the two orifice system, calibrated in the same manner as before, is also shown in Figure 2. Again, a linear relationship was obtained between regulator pressure and flow. 
FIGURE 1

The 28 liter glass battery jar inhalation chamber (from Leach, 1963). 


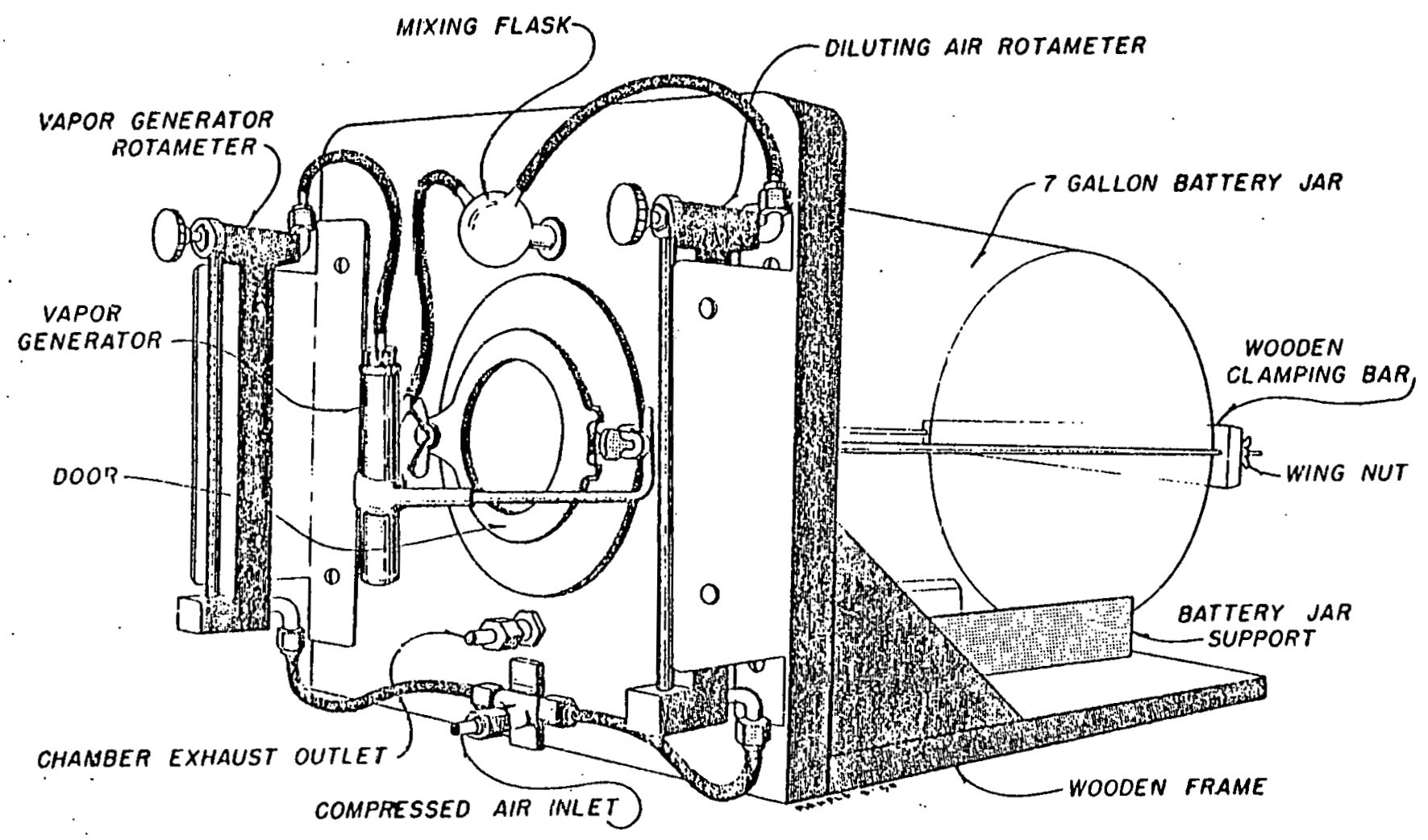

-FIGURE I. SCHEMATIC DRAWING - 
FIGURE 2

Gas flow rate versus $\mathrm{HF}$ regulator pressure for system containing one or two orifices. 


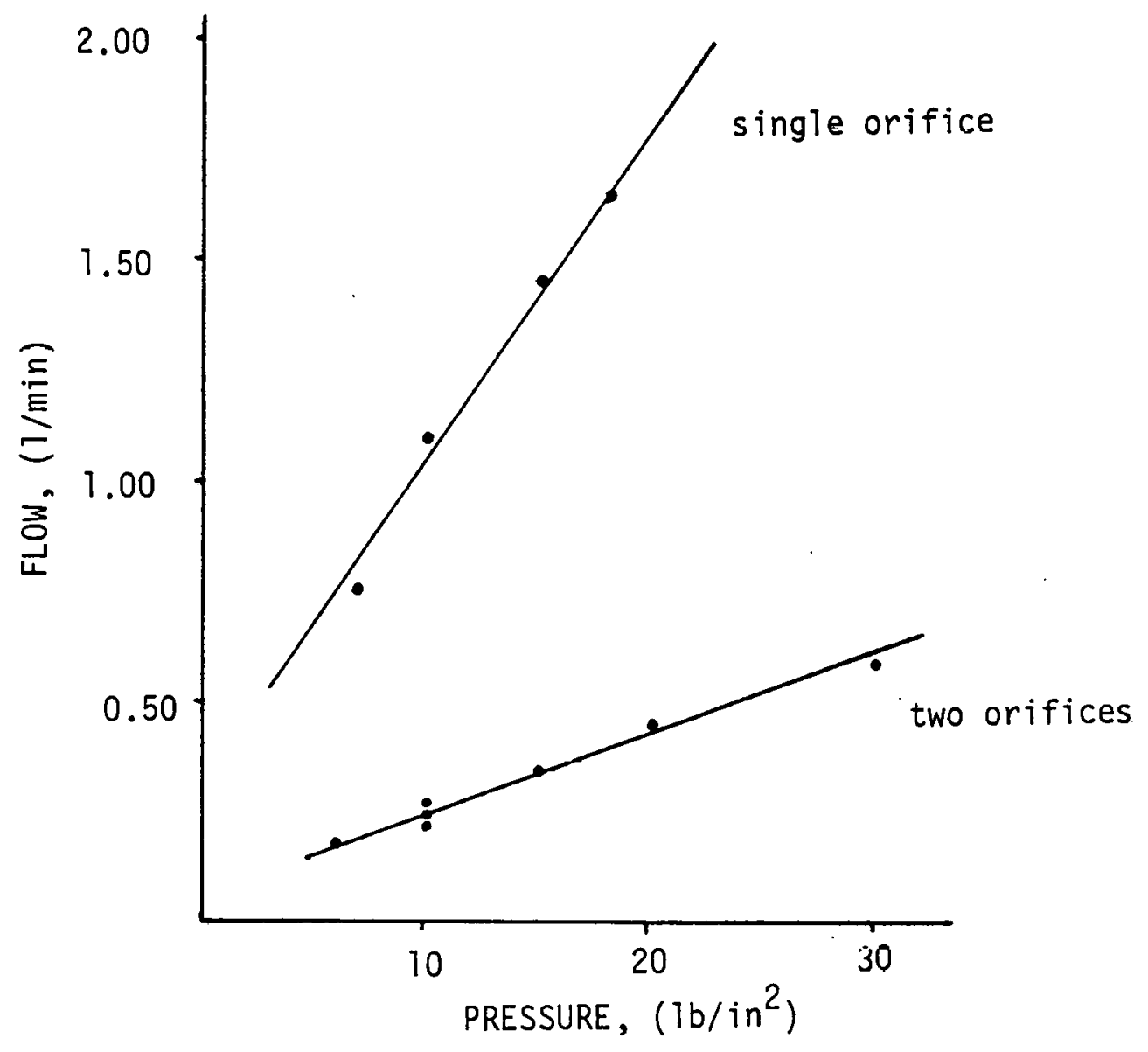


The exposure chamber was also modified for the dose response experiment. Since HF reacts with glass the glass pickle $j$ ar was replaced with a 23 liter plastic cylindrical container (a Rubbermaid waste basket, Rubbermaid, Wooster $\mathrm{OH}$ ). In addition all tygon tubing was replaced with HF resistant polyethylene tubing. The modified chamber was calibrated for two regulator pressures with both orifices in the regulator. With no rats in the chamber airborne $F$ concentrations reached steady state quickly (less than 20 minutes) and the steady state airborne fluoride concentration was in good agreement with the expected concentration calculated from the orifice calibration data (Table 5). However, with rats present in the chamber the time weighted average fluoride concentration for the exposure was much less than the fluoride concentration predicted from the orifice calibration data (Table 5). As in the preliminary experiments, exposures were of 6 hour duration in the dose-response experiments. In both cases timing of the exposure began when the flow of $\mathrm{HF}$ was started. The flow of $\mathrm{HF}$ was terminated after 6 hours, and the rats removed from the chamber 20 minutes later to allow time for chamber HF concentrations to decrease before opening the chamber door. Total air flow through the chamber was $281 / \mathrm{min}$ throughout the 6 hour exposure and 20 minute postexposure period. The chamber temperature during these exposures ranged between $21^{\circ} \mathrm{C}$ and $27^{\circ} \mathrm{C}$.

Control exposures were performed in a 281 glass battery jar inhalation chamber. Flow rates were again $281 / \mathrm{min}$. Rats were in 
TABLE 5

HF REGULATOR PRESSURE AND CHAMBER AIRBORNE FLUORIDE CONCENTRATIONS

$\begin{array}{lcccc}\begin{array}{l}\text { Regulator } \\ \text { pressure } \\ 1 \mathrm{~b} / \mathrm{in}^{2}\end{array} & \begin{array}{c}\text { Number of } \\ \text { orifices }\end{array} & \begin{array}{c}\text { Number of rats } \\ \text { in chamber }\end{array} & \begin{array}{c}\text { Measured } \\ \text { airborne } \mathrm{F} \\ \left(\mathrm{mg} \mathrm{F} / \mathrm{m}^{3}\right)\end{array} & \begin{array}{c}\text { Expected } \\ \text { airborne } \mathrm{F} \\ \left(\mathrm{mg} \mathrm{F} / \mathrm{m}^{3}\right)\end{array} \\ 10 & 2 & 0 & 50 & 70 \\ 15 & 2 & 0 & 84 & 100 \\ & & & & 65 \\ 8 & 2 & 6 & 11 & 100 \\ 15 & 2 & 6 & 27 & 170 \\ 30 & 2 & 6 & 72 & 422 \\ 15 & 1 & 6 & 116 & 622 \\ 25 & 1 & 6 & 148 & 723 \\ 30 & 1 & 6 & 179 & \end{array}$


the control chamber for a total of 6 hours and 20 minutes. Both control and HF exposed rats were sacrificed 6 hours after the termination of exposure ( 12 hours after the start of exposure). In the whole-body $\underline{\mathrm{HF}}$ retention experiment $60 \mathrm{rats}$ were exposed to HF generated by the compressed gas system for 6 hours in a 1.8 $\mathrm{m}^{3}$ Rochester chamber. Three days later 60 control rats were exposed to clean room air in a similar chamber. Both control and HF chambers were operated at a slightly negative pressure of -0.08 " water; the total air flow through these chambers was approximately $0.5 \mathrm{~m}^{3}$ per minute. Chamber temperature ranged between 24 and $25^{\circ} \mathrm{C}$. Animals were housed in pairs in stainless steel wire mesh cages during exposure and were removed from the chamber immediately after exposure. Rats were sacrificed in groups of 6 at various times up to 42 days postexposure. Seven of these control rats were sacrificed for another purpose, thus the data for only 53 control rats are reported. Rats were housed individually in metabolism cages at various times during the postexposure period. Sodium fluoride (NaF) dust exposures took place in a 28 I glass battery inhalation jar chamber. A wright dust feed was used to generate the NaF atmosphere. Analytical grade NaF was ball milled for 7 days for reduction of particle size prior to use. By placing a nozzle on the end of the diluting air line and directing the resulting airstream across the outlet tube of the wright dust feed it was possible to obtain relatively even dust concentrations throughout the chamber. Of 5 chamber locations analyzed for 
airborne NaF the one having the lowest concentration averaged 808 of the location having the highest concentration. Air flow rates were $10 \mathrm{l} / \mathrm{min}$ through the diluting air line and $191 / \mathrm{min}$ through the wright dust feed.

Air samples $(0.51 / \mathrm{min} \times 2$ minutes) were drawn through 0.8 $\mu \mathrm{m}$ pore size millipore filter for determination of airborne fluoride concentrations. The dust collected on each filter was dissolved in $10 \mathrm{ml}$ double distilled water and analyzed for fluoride content by the known addition technique. The mean chamber temperature during the exposure was $25^{\circ} \mathrm{C}$. The mass median aerodynamic diameter of the $\mathrm{NaF}$ dust was $2.8 \mu \mathrm{m}(\sigma \mathrm{g}=2.2)$.

A group of ten rats were exposed to this dust for 6 hours and were removed from the chamber immediately after the exposure. One group of 5 was sacrificed immediately postexposure, the other 5 were housed individually in metabolism cages during an 8 day postexposure period.

For intravenous infusion rats were anaesthetized with approximately $70 \mathrm{mg} / \mathrm{kg}$ sodium pentobarbital i.p. and operated on under clean but not sterile conditions. An incision was made on the ventral side of the neck, the left jugular vein was isolated and approximately $4 \mathrm{~cm}$ of PE 10 tubing (Clay Adams, Parisippany, NJ) was inserted into the vein and tied in place with surgical thread. Control and fluoride treated rats were infused continuously at a rate of $1.08 \mathrm{ml}$ per hour with a B Braun Apparatebau (Melsungen, w. Ger.) infusion pump for 1 hour. Control rats were infused with $154 \mathrm{mM} \mathrm{NaCl}$ (less than $0.005 \mathrm{\mu gF}^{-} / \mathrm{ml}$ ), 
treated rats with $32 \mathrm{mM} \mathrm{NaF}$ in $122 \mathrm{mM} \mathrm{NaCl}\left(600 \mu \mathrm{gF}^{-} / \mathrm{ml}^{-}\right)$.

Control and fluoride infused rats were sacrificed immediately or 6 hours after the end of infusion. Rats were housed individually in metabolic cages during the postexposure period.

A nose-only exposure unit was constructed from the modified pickle jar chamber and five plastic baby bottles. A diagram of this unit is contained in the schematic drawing of the upper respiratory tract exposure system (Figure 3 ). The bottles consisted of a plastic cylindrical container (the actual bottle), a plastic screw cap with a circular hole in it and a removable nipple. Thus the bottle could hold a rat in place while his nose protruded through the circular hole in the cap. Because the chamber wall was unavoidably cracked the 23 liter plastic chamber was placed in a polyethylene bag to prevent air leakage into or out of the chamber. Five caps were securely mounted over holes carved through the plastic bag and the chamber wall. The nipples were trimmed so that all that remained was an o ring which was then placed through the holes in the caps and served as a gasket to improve the seal around the rat's nose. The bottles could be easily mounted or removed from the chamber by screwing or unscrewing them from the mounted caps. Since the rats were to be anaesthetized and could thus offer no resistance the entire bottle was not necessary to hold them in place. Therefore, most of the plastic bottle was carved away from its threaded neck until all that remained was a horizontal platform to support each rat. For exposure anaesthetized rats were placed in a prone position with their noses fit snugly into the nipple gaskets. The expusure 
chamber was run at slightly negative pressure to prevent leakage of $\mathrm{HF}$ out onto the fur. Approximately $3 \mathrm{~cm}^{2}$ of the fur around the nose was in contact with the HF atmosphere which the rats were inhaling.

Initially the negative pressure in the chamber during exposure was monitored with a U tube containing water. However, it was noticed that at negative pressures of $1 / 16^{n}$ water or less the plastic bag would be sucked firmly against the wall of the chamber. If the negative pressure was lost (by movement of a $r$ at or removal of a stopper) the plastic bag expanded. Therefore, pressure in the chamber was monitored simply by observing the plastic bag. Negative pressure in the chamber was generated by connecting the outlet tube of the chamber to a water aspirator. Exposures were $r$ un at pressures just negative enough to cause the bag to contract around the chamber wall (approximately 1/16" water). Total air flow rate through the chamber was $9.5-101 / \mathrm{min}$. Chamber relative humidity was measured prior to each exposure with an Envirommental Tecktonics (Southhampton, PA) Model CP-147 psychrometer. Initial studies had indicated that chamber relative humidity did not vary during the day. Internal chamber temperature ranged between 22 and $25^{\circ} \mathrm{C}$. A. 250 watt infrared heat lamp directed on the animals was used to keep the anaesthetized rats warm.

In the normal $F$ diet $H F$ retention experiment anaesthetized ( 70 $\mathrm{mg} / \mathrm{kg}$ pentobarbital, i.p.) male Long Evans rats were exposed to $\mathrm{HF}$ generated by the compressed gas technique in the nose-only unit 
for 1 hour and sacrificed 96 hours after the start of exposure. Control rats were exposed to room air in a similar unit. Rats were housed individually in metabolism cages during the postexposure period. Excreta were collected during the $0-7,7-24,24-48,48-72$ and 72-96 hour experimental period. Timing of the experiment began at the start of exposure.

Sixteen rats were housed individually in metabolism cages during the fluoride depletion experiment. These rats were fed normal $F$ diet and tap water for three days. Then, at the start of day 0,4 rats were sacrificed and the remaining twelve were placed on low $F$ diet and distilled water. Four rats was sacrificed after 6 days on this low $F$ regimen. At the start of the 12 th day 5 rats were instilled intratracheally with $200 \mu \mathrm{gF}$. For this procedure an incision was made on the ventral side of the neck, and the trachea isolated in anaesthetized $(70 \mathrm{mg} / \mathrm{kg}$ pentobarbital, i.p.) male rats. The needle of a syringe containing $0.20 \mathrm{ml}$ of 1.0 $\mathrm{mgF}^{-} / \mathrm{ml}$ (as NaF) solution was inserted in the trachea near the larynx, pushed to a level near the bifurcation, and the contained fluid injected during the inspiratory phase of the rat's respiratory cycle. Three control rats were sham operated, the needle being inserted into the trachea but no fluid instilled. Treated rats were sacrificed 96 hours after injection (or sham operation). Timed excreta samples were collected during this 4 day postexposure period.

Timed excreta samples were also collected for 4 days after intraperitoneal fluoride injection. Two groups of fluoride 
depleted rats (injected at the beginning of the twelfth day of fluoride depletion) and one group of normal F rats were injected i.p. with $0.2 \mathrm{ml}$ of $1.0 \mathrm{mgF} / \mathrm{ml}$ as $\mathrm{NaF}$ solution $(200 \mu \mathrm{gF})$ and housed individually in metabolism cages for this experiment.

The purpose of the upper respiratory tract study was to expose only the upper respiratory tract of rats to HF. This was accomplished by inserting two endotracheal tubes made of PE 205 tubing (Clay Adams, Parsippany, NJ) into the trachea of each rat: one leading towards the lung, the other towards the mouth, and then placing the animals' head inside the HF chamber using the holder of the nose-only assembly. Thus, the rat inspired clean room air through the endotracheal tube leading towards the lung while HF laden air was drawn through the upper respiratory tract by a pump. A schematic of this exposure system is shown in Figure 3 .

For this experiment rats were anaesthetized with $70 \mathrm{mg} / \mathrm{kg}$ sodium pentobarbital (i.p.). After isolation the trachea was cut approximately $3 \mathrm{~mm}$ below the larynx. The endotracheal tube leading towards the lung was inserted to a depth of approximately $2 \mathrm{~cm}$. The endotracheal tube leading towards the mouth was inserted until its tip was just cephalad of the larynx. Both endotracheal tubes were tied in place with surgical thread. After completion of the surgical procedure the rat's nose and mouth were placed in the HF nose-only chamber. The nipple had to be removed from the bottle cap to accommodate the rat's head to this extent. The endotracheal tube leading towards the mouth was attached to a HF air sampler consisting of two midget impingers and a vacuum pump. The dead space between the rat's trachea and the first midget 
36

FIGURE 3

Schematic diagram of upper respiratory tract exposure system. 


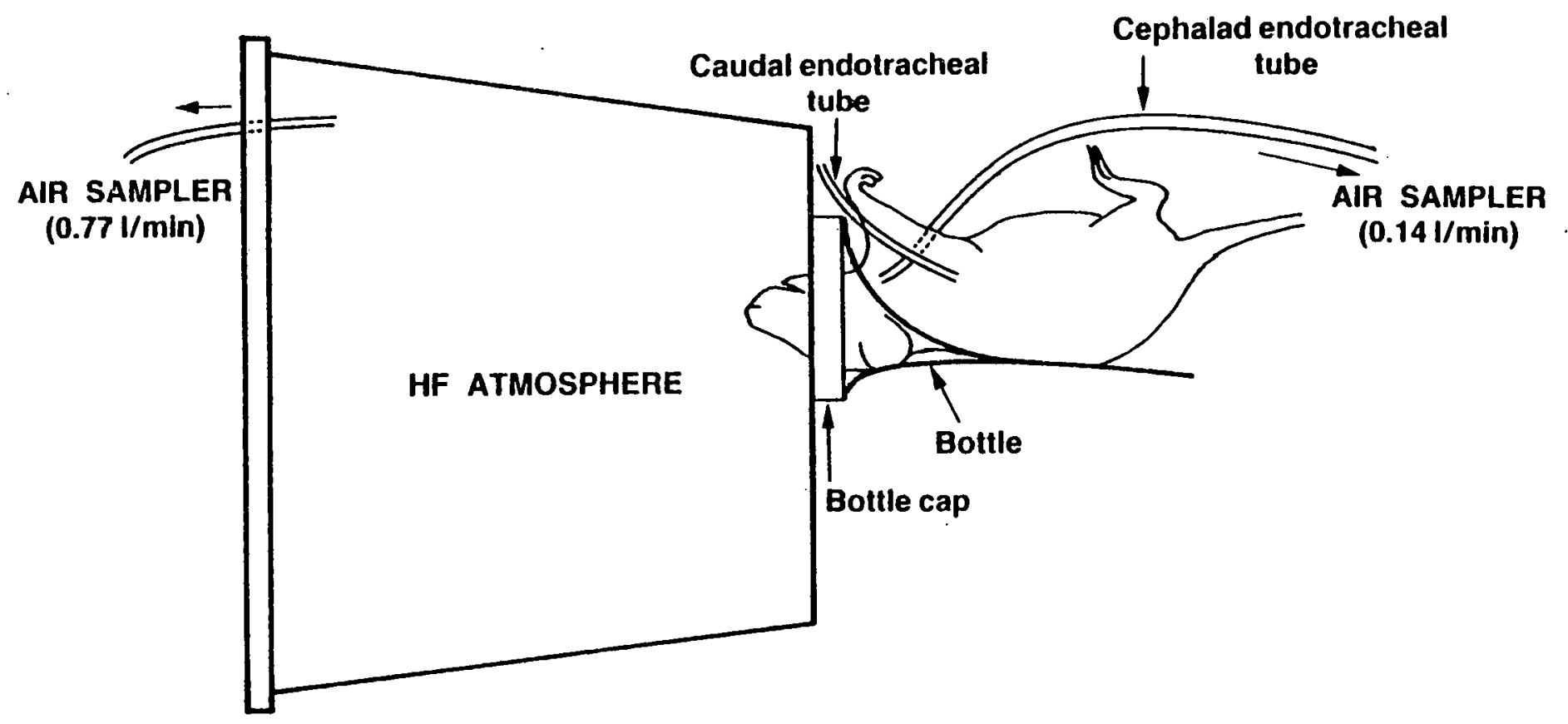


impinger was less than $1 \mathrm{~cm}^{3}$. Exposure began when the vacuum pump was turned on.

Several precautions were taken to ensure no HF would be inspired into the lungs of these rats. As is shown in Figure 3 . the endotracheal tube leading to the Iung through which the rat respired spontaneously was placed over the rim of the baby bottle cap, as far away as possible from the opening into the HF chamber. The chamber was $r$ un at negative pressure, which was monitored continuously, to ensure that no HF leaked out. In addition, the entire exposure unit was operated in a hood with clean room air continuously drawn over the rats during exposure.

Evidence that all of the air flow drawn into the air sampler actually passed through the nose, as opposed to the mouth, was obtained indirectly. When the head of a surgically prepared rat was placed under water and air was blown through the endotracheal tube, bubbles formed only at the external nares. Similarly, with only the nares under water and a vacuum pulled on the endotracheal tube, water is sucked up into the tube. If water is forced into the endotracheal tube and slight pressure is placed on the mouth, the water flows out of the nares only. This procedure was used to rinse the upper respiratory tract. Presumably the rat's tongue or epiglottis forms a seal which prevents air or water flow through the mouth. To be absolutely sure that only HF laden air was drawn into the endotracheal tube both the rat's head and mouth were placed inside the HF chamber. The fit around the head was tight enough to provide pressure on the lower jaw. 
Rats were exposed to HF in a supine position and sacrificed immediately after exposure. Blood was drawn by cardiac puncture. The upper respiratory tract was rinsed once by gently forcing $4 \mathrm{ml}$ of double distilled water into the endotracheal tube leading towards the mouth. Generally $3 \mathrm{ml}$ or more of water was collected from the external nares. HF atmospheres were generated by the compressed gas technique. Fluoride concentrations were determined in both chamber air samples and air samples which were drawn through the upper respiratory tract.

All rats in the fluoride depleted HF retention experiment were sacrificed during their 15th day on the low fluoride dietary regimen. Groups of rats were sacrificed at $I$ hour, $7,12,24$, and 96 hours after the start of the 1 hour nose-only exposure to HF. All rats were housed individually in metabolism cages fram the end of exposure to the time of sacrifice. Timed excreta samples were collected during the postexposure period. No rat urinated or defecated during exposure. HF was generated by the compressed gas technique. The sacrifice technique included several new procedures. In some rats, after removal of blood the fur around the nose was wiped with a damp $2 \times 2^{n}$ cotton gauze. This gauze was then placed in $9 \mathrm{ml}$ of double distilled water for at least 24 hours in a refrigerator. An aliquot of this extract was then analyzed for fluoride content by the procedure used for plasma. Recovery of fluoride standards by this technique averaged 110\%. The fur around the nose was wiped twice with two gauzes to determine if successive wipes removed less fluoride. After wiping, an endotracheal tube 
was inserted in the trachea to a level above the larynx. Three consecutive washes of the upper respiratory tract with $4 \mathrm{ml}$ each of double distilled water were performed as previously described. If the esophagus had been inadvertently cut it was important to clamp it shut before performing this procedure. The pelt covering the nose, from the external nares to a plane through the posterior end of the mouth, was removed and homogenized in $30 \mathrm{ml}$ of double distilled water in a Waring blender. The area of the pelt was approximately $7 \mathrm{~cm}^{2}$ and accounted for more area of the fur than was actually in contact with the HF atmosphere. The entire sacrifice procedure consisting of the procedures described above and organ removal and homogenization was not performed on every rat because it extended the sacrifice time for each animal. The exact sacrifice protocol for each rat is enumerated in the results section.

\section{Statistics}

The mean and standard error of the mean (S.E.M.) for each group of data were calculated. Groups were compared with the students t-test (Dixon and Massey, 1969). A p value less than 0.05 was required for significance. Linear regressions were performed by least squares technique. A non-parametric test, the sign test, was used to assess the significance of $\Delta F$ levels in soft tissues of control and exposed rats. 


\section{Fluoride Analysis}

Fluoride concentrations in air and tissue samples were determined with the fluoride ion sensitive electrode (Frant and Ross, 1966). For this purpose the analytical method of Cowell (1975) was modified to include the known addition technique as described by Hall, et al. (1972). Samples were ashed prior to analysis for determination of total fluoride concentration; ionic fluoride concentration was determined on unashed samples.

The fluoride ion sensitive electrode consists of a membrane permeable only to fluoride and hydroxide ion, and a reference electrode. Different fluoride concentrations in samples result in different potential differences between the fluoride and reference electrodes. The measured potential is related to fluoride concentration as described by the Nernst equation. This equation predicts that fluoride ion activity (linearly related to concentration at constant ionic strength) is logarithmically related to potential with a slope of -59.0 millivolts per decade change in fluoride activity.

Digital pH/millivolt meters (Orion Reseach, model 701 and 710A, Cambridge, MA), were used to measure electrode potential. With the use of two Orion model 605 electrode switches twelve fluoride ion sensitive electrodes (Orion Research, model 96-09) could be used at once.

For analysis, samples were allowed to equilibrate on the electrodes for at least 30 minutes or until the millivolt reading changed 0.2 millivolts or less over a 5 minute period prior to 
recording of potential. A known amount of fluoride standard solution was then added to each sample. This known addition, of $0.025 \mathrm{ml}$ volume, contained $2-3$ times the amount of fluoride originally present in the sample. After the samples had reequilibrated on the electrodes the new potential was recorded. The difference between potential readings caused by the known addition $(\Delta E)$ was then used to calculate the fluoride content originally present in the sample by the formula:

fluoride content $(\mu g)=$ known addition $(\mu g) 10^{\Delta E / 59}-1$. This formula is derived from the Nernst equation.

Standard curves were prepared with samples containing $1.0 \mathrm{ml}$ total ionic strength adjusting buffer (TISAB, Orion Research) and $1.0 \mathrm{ml}$ of fluoride standard of concentration $0.010-10.0$ $\mu \mathrm{gF}^{-} / \mathrm{ml}$ (as NaF). Total ionic strength adjusting buffer provides a constant high background ionic strength and maintains the sample $\mathrm{pH}$ between 5 and 7 to minimize hydroxide ion interference. A total of 9 different concentrations were used for each standard curve. If the standard curve was not Iinear (correlation coefficients for linear standard curves exceeded $0.995)$ or if the slope deviated from the theoretical slope, the electrode was replaced. Typically, the slopes of the standard curves for the twelve electrodes would average -58.7 millivolts per decade with a standard deviation of 0.3 millivolts per decade. In addition to being used as check for proper electrode function, the standard curves were used to estimate the amount of fluoride originally present in each sample. This estimate was then used to 
determine the appropriate fluoride standard solution for the known

addition. The analytical blank was measured daily and averaged

$0.007 \mu \mathrm{g}$. The limit of detection of this fluoride method is

approximately $0.005 \mu \mathrm{g}$.

The ionic fluoride concentration in soft tissues was measured by the same procedure as for fluoride standards. An aliquot of plasma or homogenate was added to $1.0 \mathrm{ml}$ TISAB. The total volume of each solution to be analyzed was maintained at $2.0 \mathrm{ml}$ by addition of double distilled water if less than $1.0 \mathrm{ml}$ of tissue sample was used. For plasma, untreated sample was added to TISAB for analysis of ionic fluoride concentration. Since the addition of whole homogenates to TISAB resulted in the formation of a gel, homogenates were centrifuged at $600 \mathrm{~g}$ for 10 minutes and an aliquot of the supernatant added to $1.0 \mathrm{ml}$ TISAB. In a few test samples fluoride concentration of the supernatant averaged 1028 of that in the whole homogenate (standard deviation of 28 ). In addition, no more fluoride could be rinsed out of the $600 \mathrm{~g}$ pellet than could be explained on the basis of the volume of the pellet in relation to the initial volume of the whole homogenate, suggesting that fluoride was not sequestered in the pellet. Recovery of 0.016-5.0 $\mu \mathrm{g}$ of added fluoride (as NaF) from tissue homogenates or plasma averaged $104 \pm 4.38$ (mean \pm std. dev.) for a total of 19 samples. For these analytical checks fluoride was added to the whole homogenate and the $600 \mathrm{~g}$ supernatant analyzed for fluoride; fluoride was added directly to plasma samples. Recoveries were similar in all tissues and for all amounts of added fluoride. 
Urine samples were acidified prior to determination of fluoride. To 9 parts urine (by volume), 1 part $308 \mathrm{HClO}_{4}$ was added, the solutions mixed and then centrifuged. To $2.0 \mathrm{~m} 1$ TISAB, 0.050 or $0.100 \mathrm{ml}$ of the acidified urine supernatant was added, and the ionic fluoride concentration then determined with the fluoride ion sensitive electrode by the known addition technique. The recovery of ionic fluoride added to urine cups containing mineral oil and thymol and analyzed by the urinary fluoride technique was $100 \pm 38$ (mean \pm std. dev.).

For determination of total fluoride concentration in all tissues, samples were ashed in platinum crucibles, the ash dissolved in acid and then analyzed for ionic fluoride content. Ashing and then dissolution in acid is assumed to convert all organic and inorganic fluoride to ionic fluoride. Soft tissue, fecal, food, pelt and femoral ash were all dissolved in $0.5 \mathrm{~N}$ $\mathrm{HClO}_{4}$. A $0.5 \mathrm{ml}$ aliquot of this acid dissolved ash was added to $1.5 \mathrm{ml}$ IISAB. This solution was $\mathrm{pH}$ adjusted by addition of 0.050 ml 2.5.5\% KOH and then analyzed for fluoride content by the known addition technique.

Soft tissues (lung, plasma and kidney) and urine were burned to ashes in platinum crucibles at $575^{\circ} \mathrm{C}$ overnight using 10.0 $(9.90-10.0) \mathrm{mg} \mathrm{CaO}$ as a fixative. Recovery of $0.5-10.0 \mathrm{\mu g}$ added fluoride (as NaF) from lung, kidney, plasma and urine averaged $95 \pm 11.5 \%$ (26) [mean \pm std. dev. (n)] - Recovery was similar at all levels of added fluoride and in all tissues. No more than $3.0 \mathrm{ml}$ of homogenate or plasma or $1.0 \mathrm{ml}$ of ur 1 ne were 
ashed at one time. If samples were expected to contain large amounts of fluoride (ionic fluoride content was determined prior to ashing), less than $3 \mathrm{ml}$ was ashed in an attempt to keep the amount of fluoride to less than $5 \mu \mathrm{g}$ per crucible during the ashing procedure. No value reported in this thesis for total $F$ analyzed in this manner was obtained from an aliquot containing more than 10 $\mu g$ of fluoride, i.e. sufficient fixative was always present. The ashing blank with $10 \mathrm{mg} \mathrm{CaO}$ ranged between 0.3 and $0.6 \mu \mathrm{g} \mathrm{F}$.

Tracheas were ashed at $575^{\circ} \mathrm{C}$ overnight using 100. mg $\mathrm{CaO}$ as fixative and dissolved in $10 . \mathrm{ml} 0.5 \mathrm{~N} \mathrm{HClO}_{4}$ and analyzed for fluoride as described. Recoveries of fluoride (as NaF) by the technique averaged 1008 with a standard deviation of $9.68 \quad(n=9)$. The ashing blank using $100 \mathrm{mg} \mathrm{CaO}$ averaged $2.5 \mathrm{\mu g}$ F.

Total fluoride content was determined in feces, food and pelt homogenates by a slightly different technique. Fecal samples were dried for at least 24 hours in a $60-80^{\circ} \mathrm{C}$ oven prior to analysis. Dried fecal samples (approximately 19 in mass), food samples (approximately $\mathrm{I} \mathrm{g}$ ) and pelt homogenates were ashed at $575^{\circ} \mathrm{C}$ overnight using $400 \mathrm{mg} \mathrm{CaO}$ as a fixative. These ashes were then dissolved in $100 \mathrm{ml}$ of $0.5 \mathrm{~N} \mathrm{HClO}_{4}$ and analyzed for fluoride as previously described. This ashing method is the standard method used by Smith and Gardner (personal communication). The blank for this method averaged $10 \mu \mathrm{g} \mathrm{F}$. Recovery of 20-100 $\mathrm{\mu g}$ added fluoride (as NaF) from feces by this method was $104 \pm 5.28$ (mean \pm std. dev.). 
Femoral fluoride is already fixed as fluoroapatite. Femurs were ashed overnight at $575^{\circ} \mathrm{C}$ with no fixative, dissolved in 100 $\mathrm{ml} 0.5 \mathrm{~N} \mathrm{HClO}_{4}$ and the fluoride concentration measured as previously described.

The precision of the ionic and total fluoride techniques vary for each tissue because differing amounts of tissue were used in each procedure and differing analytical blanks were involved with each procedure. Because fluoride is so ubiquitous every step in the preparation and analysis of tissue adds more fluoride to each sample. Thus there is no true limit of detection for each method because the limit of detection for the electrodes themselves is smaller than the amount of fluoride picked up by each sample during preparation. It is therefore, crucial that appropriate blank corrections be determined for each preparation and analytical technique.

The ionic fluoride concentration in lung and kidney is reported to the nearest $0.01 \mu \mathrm{g} / \mathrm{g}$ and could be determined to \pm $0.04 \mu \mathrm{g} / \mathrm{g}$. The ionic fluoride concentration in plasma is reported to the nearest $0.001 \mu \mathrm{g} / \mathrm{ml}$ and could be detemined to \pm $0.002 \mu \mathrm{g} / \mathrm{ml}$. The ionic fluoride concentration in urine is reported to the nearest $0.01 \mu \mathrm{g} / \mathrm{ml}$ and could be determined to $\pm 0.04 \mu \mathrm{g} / \mathrm{ml}$. The coefficient of variation for these ionic fluoride methods is 4.38 .

The coefficient of variation of the total fluoride method using 10. $\mathrm{mg} \mathrm{CaO}$ is 11.58. Total fluoride concentration in lung and kidney is reported to the nearest $0.1 \mu \mathrm{g} / \mathrm{g}$ and could be 
determined to $\pm 0.3 \mu \mathrm{g} / \mathrm{g}$. Total plasma fluoride concentration is reported to the nearest $0.01 \mu \mathrm{g} / \mathrm{ml}$ and could be determined to \pm $0.04 \mu \mathrm{g} / \mathrm{ml}$. Total urine fluoride is reported to the nearest $0.1 \mu \mathrm{g} / \mathrm{ml}$ and could be determined to $\pm 0.1 \mu / \mathrm{ml}$.

The total fluoride concentration in trachea is reported to the nearest $1 . \mu \mathrm{g} / \mathrm{g}$ and could be determined to $\pm 1 . \mu \mathrm{g} / \mathrm{g}$. The total fluoride concentration in food and feces is reported to the nearest $0.1 \mu \mathrm{g} / \mathrm{g}$ and could be determined to $\pm 0.8 \mu \mathrm{g} / \mathrm{g}$. Total fluoride content in the femur is reported to the nearest $1 . \mu \mathrm{g}$ and could be determined to $\pm 1 . \mu \mathrm{g}$.

In soft tissues total fluoride concentrations consistently exceeded ionic fluoride concentration. This was considered to be due to a fluoride component which did not respond to the fluoride ion sensitive electrode. This fraction was termed the $\Delta F$ fraction. The concentration of fluoride in this fraction was calculated by subtracting the ionic fluoride concentration in each tissue sample from the total fluoride concentration in that sample. Since there is analytical error involved in both the ionic and total fluoride techniques the value obtained for the $\Delta F$ concentration is necessarily imprecise. The coefficient of variation for the determination of $\Delta F$ concentration can be estimated to be $12.38\left(4.38^{2}+11.5^{2}\right)^{1 / 2}$. Because of this large coefficient of variation it would be expected that both positive and negative $\Delta F$ concentrations would be obtained. For example, if total fluoride concentration equalled ionic fluoride concentration, in $5 \%$ of the groups of tissues analyzed total 
fluoride concentration would be expected to average $24.6 z$ ( 2 times the relative standard deviation of 12.38 ) less than the ionic fluoride concentration. However, if the detection of $\Delta F$ were due only to random analytical error an equal number of positive and negative $\Delta F$ concentrations would be expected. Therefore, the significance of the occurrence of $\Delta F$ fraction in tissue from each experiment was assessed by tabulation of the number of positive and negative $\Delta F$ concentrations obtained.

\section{$\Delta F$ Characterization}

Lung and kidney homogenates of rats sacrificed 22 hours after exposure to $380 \mathrm{mg} \mathrm{F} / \mathrm{m}^{3}$ were subjected to acid or base treatment to determine if such treatment would convert the fluoride in the $\Delta F$ fraction to a form responsive to the fluoride ion sensitive electrode. For acid treatment $0.200 \mathrm{ml}$ of 308 trichloracetic acid was added to $1.0 \mathrm{mI}$ of whole homogenate, mixed and centrifuged at $600 \mathrm{~g}$ for 10 minutes. Ionic fluoride concentration was determined on a $0.100 \mathrm{ml}$ aliquot of the supernatant. The analytical blank for this procedure averaged $0.01 \mu \mathrm{g}$. Base treatment consisted of digestion in potassium hydroxide. A $0.200 \mathrm{ml}$ aliquot of whole homogenate was added to $1.0 \mathrm{ml} 25.58 \mathrm{kOH}$ and heated in a boiling water bath for 30 minutes. An $0.8 \mathrm{ml}$ aliquot of the digest was added to $1.2 \mathrm{ml}$ TISAB and the fluoride concentration determined with the fluoride ion sensitive electrode. Solutions of sodium monofluoroacetate, sodium monofluoroproprionate and trifluoroacetic acid were treated similar1ly. The blank for the digestion 
procedure averaged $0.180 \pm 0.020 \mu \mathrm{g}$ (mean \pm std. dev.).

The remaining kidney homogenates from this group of animals were pooled and subjected to dialysis. Ten $\mathrm{ml}$ of kidney homogenate pool was placed in $4.8 \mu \mathrm{m}$ pore diameter seamless dialyzer tubing (Fisher Scientific, Pittsburgh, PA) and dialyzed against double distilled water for 24 hours. The water was changed 3 times during this period. Total and ionic fluoride concentrations were determined by the standard techniques.

Plasma obtained from rats sacrificed 6 hours after a 6 hour exposure to $84 \mathrm{mg} \mathrm{F} / \mathrm{m}^{3}$ were separated into ionizable and non-ionizable fluoride fractions by the calcium phosphate adsorption technique of Venkateswarlu, et al. (1971). $1.0 \mathrm{ml}$ of plasma plus $2.0 \mathrm{ml}$ of double distilled water were added to $10.0 \mathrm{mg}$ crystalline calcium phosphate and incubated at $38^{\circ} \mathrm{C}$ for 1 hour in a shaking water bath. After centrifugation at $600 \mathrm{~g}$ for 20 minutes the supernatant was decanted of the calcium phosphate pellet. A volume of approximately $2.6 \mathrm{ml}$ was removed by the decanting procedure. After the calcium phosphate pellet had completely dissolved in $0.5 \mathrm{ml} 0.5 \mathrm{~N} \mathrm{HClO}_{4}, 2.0 \mathrm{ml} 0.5 \mathrm{M}$ sodium citrate was added. Ionic fluoride concentration was determined on $0.5 \mathrm{ml}$ aliquots of the dissolved calcium phosphate layer and the supernant layer. Total fluoride concentration was determined on 1.5-2.0 $\mathrm{ml}$ of each layer by the method described for plasma. The remaining untreated plasma samples from this group of animals (84 $\mathrm{mg} \mathrm{F} / \mathrm{m}^{3} \mathrm{HF}$ exposed) were pooled and subjected to Sephadex G-25 gel chromatography. This procedure separates 
molecules on the basis of their molecular radius. Gel

chromatography was performed at $25^{\circ} \mathrm{C}$ by the same procedure as described by Thomas (1977). Two ml of plasma was layered on top of a $33 \mathrm{~cm} \times 1.6 \mathrm{~cm}$ Sephadex G-25 column and eluted with $28.2 \mathrm{ml}$ per hour 0.05 ammonium acetate ( $\mathrm{pH} 7.0$ ) for 4 hours. Elution samples, each of $2.8 \mathrm{ml}$ volume were collected every 6 minutes. The ionic and total fluoride content of each sample was determined by the method described for plasma. Dextran Blue 2000 (Sigma Chemical, St. Louis, MO) was used for determination of void volume. 
RESULTS AND COMMENTS

I. Whole Body Exposures

A. Preliminary Experiments

The preliminary experiments consisted of two range finding exposures to HF. These exposures were performed to gain information on the levels of airborne HF which could be generated and maintained by the aqueous system, the systemic fluoride burden of HF exposed animals and the toxic effects on lung and kidney resulting from $\mathrm{HF}$ exposure. Since the acute toxicity of $\mathrm{HF}$ was of interest animals were subjected to a single exposure. For reasons of safety it was decided to expose the animals to HF for as long as practical to minimize the airborne concentrations of HF necessary to produce toxic effects, rather than to use very high concentrations even for only brief periods. To this end a 6 hour exposure period was decided upon. Animals were sacrificed at various times up to 24 hours after the start of exposure to investigate any delayed effects.

In the first exposure 15 male Long Evans rats obtained from Blue Spruce Farms were exposed to HF for 6 hours in a 28 liter glass battery jar inhalation chamber and sacrificed immediately (20 minutes to 1 hour) 6 hours or 18 hours after the exposure. Because no specific airborne $F$ concentration was intended for this exposure, it was decided to use a flow rate of 4 liters/min through the bubbler and then determine the resulting HF levels. Airborne fluoride concentrations measured at various times during the exposure arc shown in Figure 4. The generator was shut down 3 
FIGURE 4

Measured airborne fluoride concentrations versus exposure time for the $55 \mathrm{mg} \mathrm{F} / \mathrm{m}^{3} \mathrm{HF}$ exposure. 


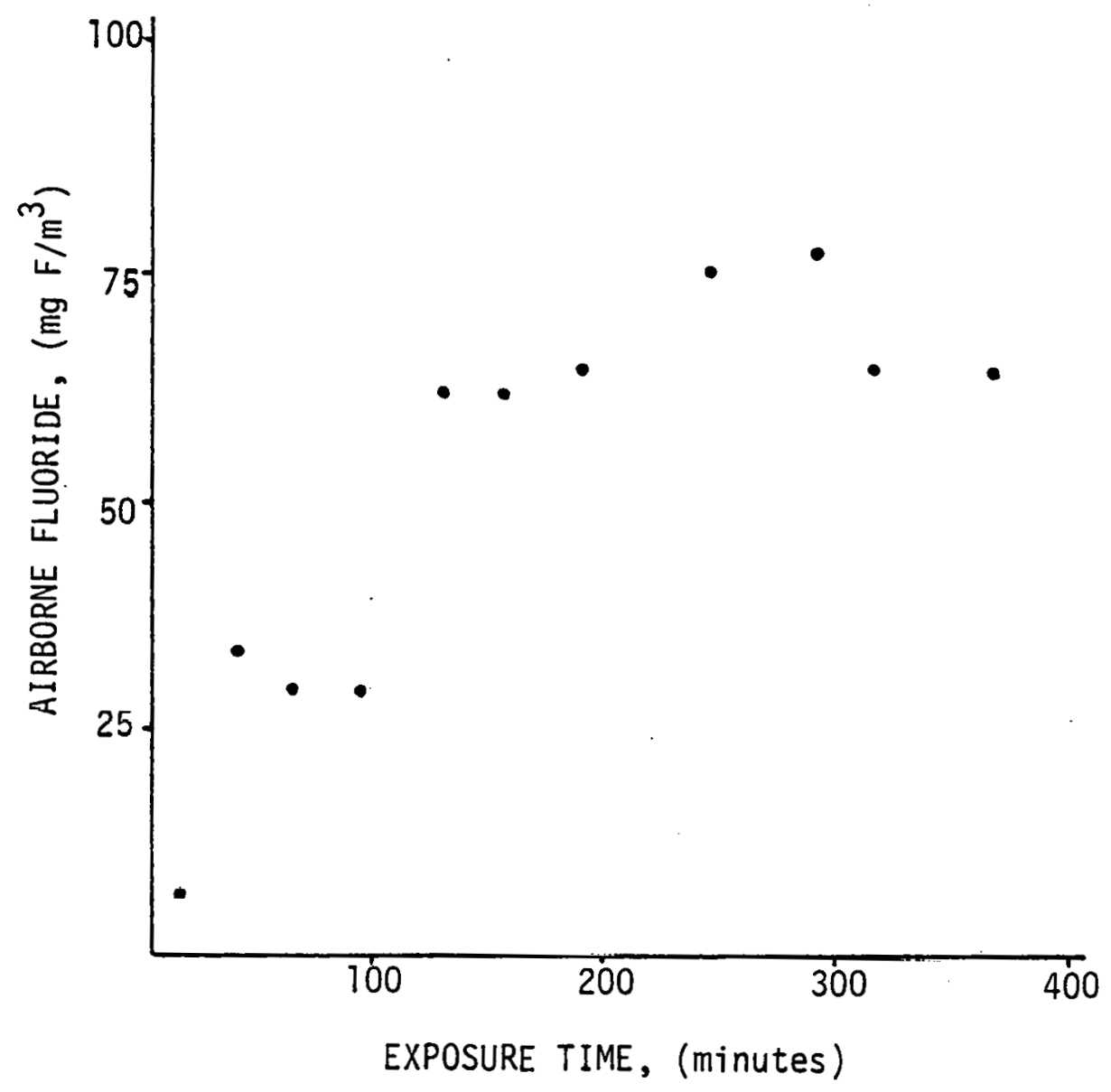


minutes for repairs from time 38-41 minutes. The time weighted average fluoride concentration for the exposure was $55 \mathrm{mg} \mathrm{F} / \mathrm{m}^{3}$.

Rats were fasted during the postexposure period but had access to water. Control animals were sacrificed after a 24 hour fast and were not chamber exposed. No mortality occurred and no gross pathologic alterations were seen in any animal, control or exposed. The renal and pulmonary effects of this exposure are given in Table 6. The kidney weight to body weight ratio increased with time after the exposure suggesting some effect of HF exposure on the organ. In animals sacrificed 18 hours postexposure this ratio was significantly higher than in control animals. The lung weight to body weight ratio was not significantly different from control levels at any sacrifice time. However, the lung wet weight to dry weight ratio was significantly elevated in animals sacrificed inumediately or 6 hours postexposure. The lungs of animals sacrificed 6 hours postexposure contained an average of $14 \%$ more water than did control lungs. The lung wet weight to dry weight ratio in rats sacrificed 18 hours postexposure was not different from control levels.

The measured fluoride concentrations in soft tissues of rats after exposure to $55 \mathrm{mg} \mathrm{F} / \mathrm{m}^{3} \mathrm{HF}$ are given in Table 7. Total and ionic fluoride concentrations were sionificantly hioher than control levels at all 3 sacrifice times. In lung and kidney total fluoride concentration did not change with time after exposure while the plasma total fluoride concentration increased significantly during the postexposure period. Ionic fluoride 
TABLE 6

PULMONARY AND RENAL EFFECTS OF EXPOSURE

TO $55 \mathrm{mgF} / \mathrm{m}^{3}$ HF FOR 6 HOURS 1

Sacrifice Time

(hours postexposure)

Imnediate $1 y$

( $<1$ hour)

6 hour

Control

18 hour
269

(5)

263

(5)

245

(5)

250

5

$(5)$
Lung

Wet Wt. Lung Wt. Kidney

(g)

$(\mathrm{g} / \mathrm{kg})$

$(\mathrm{g} / \mathrm{kg})$
4.73

.27

(5)

(5)

$5.25^{a}$

.21

(5)

5.06

.23

(4)

4.68

.07

(5)

5.20

.67

(4)

5.18

.30

(5)

$7.46^{b}$

.20

(5)

8.14

.31

(5)

$8.49 \mathrm{a}$

.18

(5)

4.62

(5)
7.68

.23

(5)

1 Values expressed as mean, S.E.M., (number of animals per group). HF generated by aqueous system

a $p<0.05$ compared to control

b $\quad p<0.01$ compared to control 


\section{TABLE 7}

MEASURED FLUORIDE CONCENTRATIONS IN SOFT TISSUES OF RATS EXPOSED TO $55 \mathrm{mg} \mathrm{F} / \mathrm{m}^{3}$ HF FOR 6 HOURS 1

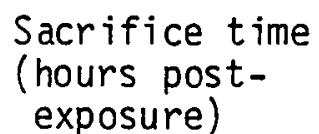

Immed iate ly

6 hour

18 hour

Control

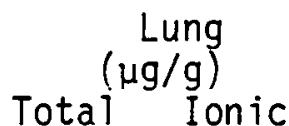

$\begin{array}{rr}6.9 & 5.26 \\ .7 & .61\end{array}$

(5)

(5)

$6.6 \quad 3.46$

.5

(5)

.27

(5)
$7.0 \quad 3.05$
$.5 \quad .21$
(5)
(5)

$\begin{array}{rr}1.1 & 0.10 \\ .1 & .02 \\ (5) & (5)\end{array}$
Plasma
$(\mu \mathrm{g} / \mathrm{ml})$
Total Ionic

Kidney
$(\mu g / g)$
Total Ionic

3.4

(5)

2.41

.53

(5)

$6.1 \quad 5.08$

$1.1 \quad .77$

(5)

(5)

\section{7 \\ .6}

(5)

1.39

.20

(5)

$\begin{array}{rr}7.2 & 1.74 \\ 1.7 & .41\end{array}$

(5)

(5)

.15

(2)
$6.0 \quad 3.10$

$1.1 \quad .33$

(5)

(5)

$8.0 \quad 3.84$

$2.0 \quad .70$

(5)

(5)

$0.4 \quad 0.06$

$.1 \quad .01$

(5)

(5)

1 Values expressed as mean, S.E.M., (number of animals per group). HF generated by aqueous system. 
concentrations in all three tissues appeared to decrease with time after exposure. In control and exposed rats ionic fluoride did not account for all the fluoride present in these three soft tissues.

The $\Delta F$ concentrations (the difference between total $F$ and ionic $F^{-}$) in soft tissues after this exposure to $\mathrm{HF}$ are given in Table 8. The total fluoride concentration in each tissue is given for comparison. In lung, plasma and kidney of all exposed rats $\Delta \mathrm{F}$ concentration was significantly higher than control levels. In addition the $\Delta F$ concentration in all three tissues increased with time after the exposure. In animals sacrificed 18 hours postexposure $\Delta F$ accounted for $56 \%$ of the total fluoride present in lung, 518 of the total fluoride present in kidney and $78 \%$ of the total fluoride present in plasma.

In the second experiment 12 rats (male Long Evans) were exposed to $380 \mathrm{mg} \mathrm{F} / \mathrm{m}^{3}$ for 2 hours and sacrificed at intervals up to 22 hours postexposure. The purpose of this experiment was to expose the rats to as high a concentration as feasible with the aqueous system generation technique. The animals used in this experiment had been exposed to $8.3 \mathrm{mg} \mathrm{F} / \mathrm{m}^{3}$ HF for 75 minutes nine days previously. That earlier exposure had been terminated because of problems with the generator. It is recognized that the previous exposure might have affected their response to HF. To maximize the airborne HF levels 498 hydrofluoric acid was placed in the aqueous system bubbler and the water bath temperature was raised to $60^{\circ} \mathrm{C}$. The measured airborne fluoride concentrations at various times during the exposure are shown in rigure 5. The exposure was 


\section{TABLE 8}

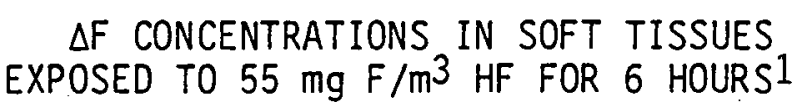

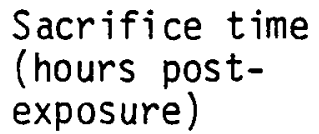

Immediate ly

(<1 hour)

6 hour

18 hour

Control

\section{$\begin{array}{ll}6.9 & 1.7\end{array}$}

(5)

(5)

$\begin{array}{ll}6.6 & 3.2\end{array}$

$.5 \quad .3$

(5) (5)

$7.0 \quad 3.9$

.5

(5)

(5)

1.11 .0

(.1

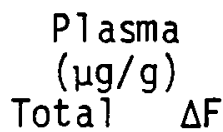

$3.4 \quad 1.1$

$.8 \quad .4$

(5) (5)

$5.7 \quad 4.2$

$0.6 \quad .4$

(4) (4)

$7.2 \quad 5.5$

$1.7 \quad 1.4$

(5) (5)

$.15 \quad .12$

(2)

(2)
Kidney
$(\mu \mathrm{g} / \mathrm{g})$
$\operatorname{Total} \Delta \mathrm{F}$

$6.1 \quad 1.6$

1.1 .4

(5) (5)

$\begin{array}{ll}6.0 & 2.9\end{array}$

$1.1 \quad .9$

(5) (5)

$8.0 \quad 4.1$

$2.0 \quad 1.3$

(5) (5)

$0.4 \quad 0.3$

.1 .1

(5) (5)

1 Values expressed as mean, S.E.M., (number of animals per group). HF generated by aqueous system. 
FIGURE 5

Measured airborne fluoride concentration versus exposure time for the $380 \mathrm{mg} \mathrm{F} / \mathrm{m}^{3} \mathrm{HF}$ exposure. 


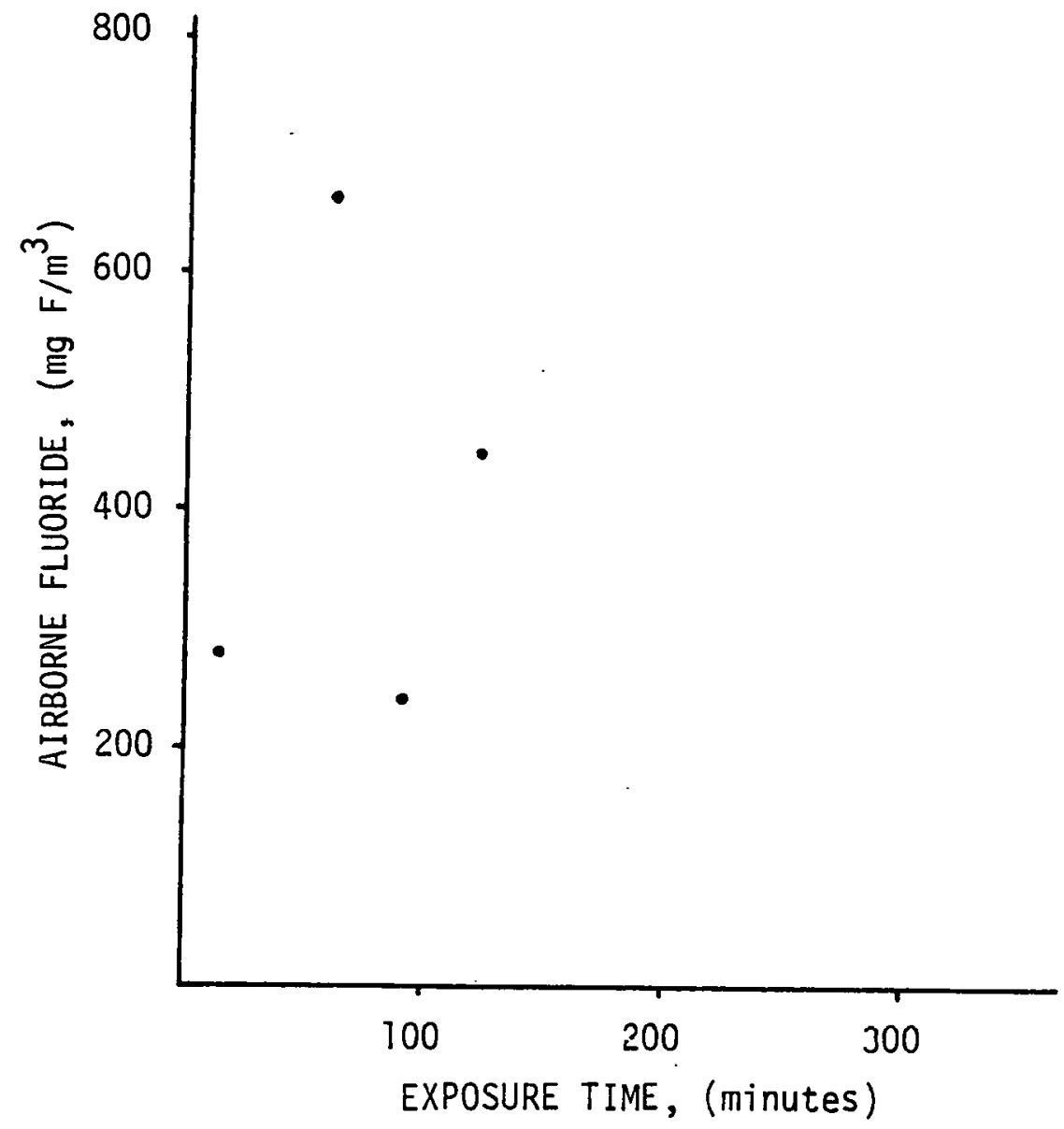


terminated after two hours because the HF destroyed the tygon tubing connecting the generator to the chamber. In addition, the generator twice had to be shut down for repairs during the exposure. Again, animals had access to water but not food during the postexposure period. Control animals were not chamber exposed and were sacrificed after a 24 hour fast.

Several signs of irritation and toxicity were noticed in animals during exposure to this concentration of HF. These signs included watering of the eyes, pawing at the nose, discharge of fluid from the external nares and abnormal breathing patterns characterized by large abdominal breaths. All animals were wheezing upon removal from the chamber. Another common finding was the presence of numerous small blood clots on the front paws and at the external nares. No mortality occurred during the exposure or during the 22 hour postexposure period.

The pulmonary effects following exposure to $380 \mathrm{mg} \mathrm{F} / \mathrm{m}^{3} \mathrm{HF}$ are given in Table 9. The lung weight to body weight ratio increased with time after the exposure. In rats sacrificed 22 hours postexposure this ratio was significantly higher than in control rats. The lung wet weight to dry weight ratio was significantly elevated in rats sacrificed 6 hours postexposure and significantly lower than control values in rats sacrificed 22 hours pos te xposure.

In no sacrifice group was the kidney weight to body weight significantly different from control levels (Table 9). However, at each sacrifice time the blood urea nitrogen (BUN) was signficantly 
PULMONARY AND RENAL EFFECTS OF EXPOSURE

TO $380 \mathrm{mgF} / \mathrm{m}^{3} \mathrm{HF}$ FOR 2 HOURS 1

\begin{tabular}{|c|c|c|c|c|c|}
\hline $\begin{array}{l}\text { Sacrifice Time } \\
\text { (hours post- } \\
\text { exposure }\end{array}$ & $\begin{array}{c}\text { Body Wt. } \\
(\mathrm{g})\end{array}$ & $\begin{array}{l}\text { Lung Wt. } \\
\text { Body Wt. } \\
\text { (g/kg) }\end{array}$ & $\begin{array}{l}\text { Lung } \\
\text { Wet Wt. } \\
\text { Dry Wt. }\end{array}$ & 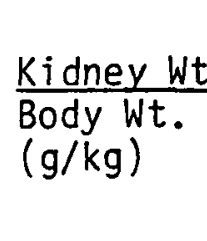 & $\begin{array}{l}\text { t. } \\
\text { BUN } \\
\text { mg\% }\end{array}$ \\
\hline $\begin{array}{l}\text { Immediately } \\
(<1 \text { hour })\end{array}$ & $\begin{array}{r}314 \\
11 \\
(4)\end{array}$ & $\begin{array}{r}5.09 \\
.29 \\
(4)\end{array}$ & $\begin{array}{r}5.06 \\
.11 \\
(4)\end{array}$ & $\begin{array}{r}7.67 \\
.32 \\
(4)\end{array}$ & $\begin{array}{c}14.4^{a} \\
1.0 \\
(4)\end{array}$ \\
\hline 6 hour & $\begin{array}{r}295 \\
9 \\
(4)\end{array}$ & $\begin{array}{r}5.35 \\
.37 \\
(4)\end{array}$ & $\begin{array}{l}4.99 a \\
.04 \\
(4)\end{array}$ & $\begin{array}{r}7.70 \\
.18 \\
(4)\end{array}$ & $\begin{array}{c}25.8^{b} \\
3.5 \\
(4)\end{array}$ \\
\hline 22 hour & $\begin{array}{r}286 \\
2 \\
(4)^{2}\end{array}$ & $\begin{array}{c}5.47^{a} \\
.14 \\
(4)\end{array}$ & $\begin{array}{l}4.59 a \\
.05 \\
(4)\end{array}$ & $\begin{array}{r}8.65 \\
.29 \\
(4)\end{array}$ & $\begin{array}{l}73.6^{b} \\
18.5 \\
(4)\end{array}$ \\
\hline Control & $\begin{array}{l}285 \\
10 \\
(4)\end{array}$ & $\begin{array}{r}4.81 \\
.20 \\
(4)\end{array}$ & $\begin{array}{r}4.81 \\
.05 \\
(4)\end{array}$ & $\begin{array}{r}7.89 \\
.15 \\
(4)\end{array}$ & $\begin{array}{l}9.6 \\
1.1 \\
(4)\end{array}$ \\
\hline
\end{tabular}

1 Values expressed as mean, S.E.M., (number of animals per group) $\mathrm{HF}$ generated by aqueous system

a $p<0.05$ compared to control

b $\quad p<0.01$ compared to control 
elevated. BUN also increased with time during the postexposure period.

The measured fluoride concentrations in lung, plasma and kidney of rats sacrificed at each postexposure time are given in Table 10. The total and ionic fluoride concentrations in all three soft tissues of the control rats are significantly higher than in the previous control group suggesting that these animals retained some fluoride from the $8.3 \mathrm{mg} \mathrm{F} / \mathrm{m}^{3} \mathrm{HF}$ exposure. Total and ionic fluoride concentrations in lung, plasma and kidney were significantly elevated at all three sacrifice times after exposure to $380 \mathrm{mg} \mathrm{F} / \mathrm{m}^{3} \mathrm{HF}$. In lung, total and ionic fluoride concentrations decreased with time after exposure. In plasma, total fluoride concentration increased with each succeeding sacrifice group while ionic fluoride concentrations remained unchanged. Total flouride concentration remained constant in kidney while ionic fluoride concentrations in this organ decreased with time after exposure. As in the previous experiment, ionic fluoride did not account for the total fluoride present in these three soft tissues. In rats sacrificed 22 hours postexposure the ionic fluoride concentration in lung, plasma and kidney averaged 728,358 and 608 respectively of the total fluoride concentration. The $\Delta F$ concentrations in soft tissues of rats after exposure to $380 \mathrm{mg} \mathrm{F} / \mathrm{m}^{3} \mathrm{HF}$ are given in Table 11 . The $\Delta F$ concentrations in lung, plasma and kidneys of rats sacrificed at all postexposure times were significantly higher than control levels. The $\Delta F$ concentrations in all three tissues of rats sayidiced 22 hours 
MEASURED FLUORIDE CONCENTRATIONS IN SOFT TISSUES OF RATS EXPOSED TO $380 \mathrm{mg} \mathrm{F} / \mathrm{m}^{3}$ HF FOR 2 HOURS 1

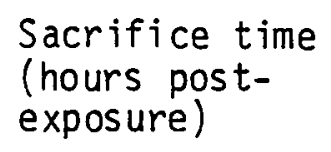

Immediately

$(<1$ hour)

6 hour

22 hour

Control

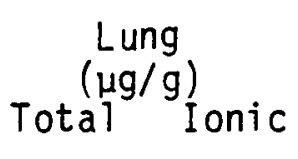

85. $\quad 77.5$

13. $\quad 14.5$

(4)

(4)

86. $\quad 79.3$

(4)

(4)

52. $\quad 37.3$

(4)

(4)

3.6

(4)
1.72
$(4)$

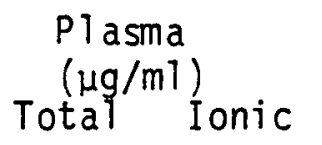

3.5 .

i 5

5.7

i 9

(3)

11.1

(4)

.32

.07

(4)
3.56

.73

(4)

3.87

.44

(4)

3.84

.36

(4)

.14

.03

(4)
Kidney
$(\mu \mathrm{g} / \mathrm{g})$ Ionic
Total Ion

27.

1.9

(4)

25.5

1.1

(4)

24.

(4)

22.5

5.9

(4)

26. $\quad 15.7$

$1.8 \quad 1.3$

(4)

(4)

0.9

(4)

$(4)^{.7}$

1 Values expressed as mean, S.E.M., (number of animals per group). HF generated by aqueous system. 


\section{TABLE 11}

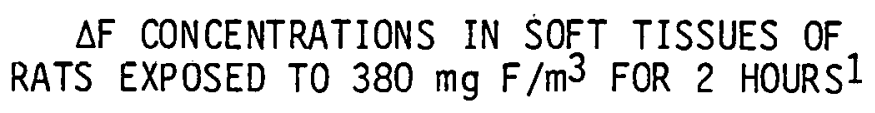

\begin{tabular}{|c|c|c|c|c|c|c|}
\hline \multirow{2}{*}{$\begin{array}{l}\text { Sacrifice time } \\
\text { (hours post- } \\
\text { exposure) }\end{array}$} & \multicolumn{2}{|c|}{$\begin{array}{l}\text { Lung } \\
(\mu q / q)\end{array}$} & & \multicolumn{2}{|c|}{$\begin{array}{c}\text { Kidney } \\
(\mu \mathrm{g} / \mathrm{g})\end{array}$} \\
\hline & Total & $\Delta F$ & Total & $\Delta \mathrm{F}$ & Total & $\Delta F$ \\
\hline $\begin{array}{l}\text { Immediately } \\
(<1 \text { hour })\end{array}$ & $\begin{array}{l}85 . \\
13 . \\
(4)\end{array}$ & $\begin{array}{l}7.4 \\
2.2 \\
(4)\end{array}$ & $\begin{array}{l}3.5 \\
.5 \\
(4)\end{array}$ & $\begin{array}{l}-0.1 \\
(4)^{2}\end{array}$ & $\begin{array}{l}27.9 \\
1.9\end{array}$ & $\begin{array}{l}1.8 \\
1.1 \\
(4)\end{array}$ \\
\hline 6 hour & $\begin{array}{l}86 . \\
9: 3 \\
(4)\end{array}$ & $\begin{array}{l}6.3 \\
2.0 \\
(4)\end{array}$ & $\begin{array}{l}5.7 \\
.9 \\
(4)\end{array}$ & $(4)^{1.8}$ & $\begin{array}{r}24 . \\
4.3 \\
(4)\end{array}$ & $\begin{array}{l}1.8 \\
2.2 \\
(4)\end{array}$ \\
\hline 22 hour & $\begin{array}{l}52 . \\
3.8 \\
(4)\end{array}$ & $\begin{array}{r}14.4 \\
1.7 \\
(4)\end{array}$ & $\begin{array}{c}11.1 \\
2.3 \\
(4)\end{array}$ & $\begin{array}{l}7.3 \\
1.9 \\
(4)^{9}\end{array}$ & $\begin{array}{r}26 . \\
1.8 \\
(4)\end{array}$ & $\begin{array}{l}10 . \\
0.5 \\
(4)^{-}\end{array}$ \\
\hline Control & $\begin{array}{l}3.6 \\
.3 \\
(4)\end{array}$ & $\begin{array}{l}1.9 \\
\dot{4} \\
(4)\end{array}$ & $\begin{array}{l}.32 \\
.07 \\
(4)\end{array}$ & $\begin{array}{l}.18 \\
.04 \\
(4)\end{array}$ & $\begin{array}{r}.9 \\
.3 \\
(4)\end{array}$ & $\begin{array}{l}0.2 \\
(4)^{3}\end{array}$ \\
\hline 3 & as & & lumb & & & \\
\hline
\end{tabular}


postexposure were significantly higher than in rats sacrificed immediately after the exposure.

Some preliminary studies on the nature of $\Delta F$ in lung and kidney of rats sacrificed 22 hours postexposure were undertaken. Homogenates were treated with acid ( $30 \%$ trichloracetic) or base ( 30 minute digestion in $218 \mathrm{KOH})$ to determine if such treatment would convert the fluoride present in the $\Delta F$ fraction to a form which would respond to the fluoride ion sensitive electrode. Digestion of lung homogenates in $\mathrm{KOH}$ did not result in an increase in the ionic fluoride concentration (Table 12). Such treatment has been shown to convert $100 \%$ of the fluoride in sodium monofluroacetate to ionic fluoride, and 948 of the fluoride in sodium monofluroproprionate to ionic fluoride. However, less than 18 of the fluoride in trifluoroacetic acid was released as ionic $\mathrm{F}^{-}$by this procedure. The failure of $\mathrm{KOH}$ digestion to increase ionic $\mathrm{F}^{-}$in lung homogenates suggests that $\Delta F$ is not a simple aliphatic monoflurocarbon compound.

The ionic fluoride concentration in lung homogenates was unaffected by treatment with trichloracetic acid. However, the ionic fluoride concentration of kidney homogenates was significantly increased by this acid treatment. Sixty-four percent of the fluoride in the $\Delta F$ fraction of kidney homogenate was converted to ionic fluoride.

The remaining untreated kidney homogenates were pooled and subjected to dialysis. Before dialysis the total, ionic and $\Delta F$ concentrations in the homogenate were $7.1 \mu \mathrm{g} / \mathrm{ml}, 5.6 \mu \mathrm{g} / \mathrm{ml}$ and 


\section{TABLE 12}

CHARACTERIZATION OF $A F$ IN SOFT TISSUES OF RATS EXPOSED

TO $380 \mathrm{mg} \mathrm{F} / \mathrm{m}^{3}$ FOR 2 HOURS 1

Untreated
$(\mu \mathrm{g} / \mathrm{g})$
Total Ionic $\Delta F$

Lung

52. $\quad 37.3 \quad 14.4$

$3.8 \quad 3.3 \quad 1.7$

(4)

(4)

(4)

Kidney 26. $\quad 15.7 \quad 10.4$

$1.8 \quad 1.3$

(4) (4)

(4)

Acid Treated

$(\mu \mathrm{g} / \mathrm{g})$

Ionic Acid Labile Ionic Base Labile

Base Treated

$$
(\mu \mathrm{g} / \mathrm{g})
$$

$\begin{array}{ll}38.2 & 1.0 \\ 4.2 & 1.0 \\ (4) & (4) \\ & \\ 22.4 & 6.7 \\ 2.2 & 1.1 \\ 4 j^{2} & (4)\end{array}$

1 Values expressed as mean, S.E.M., (number of animals per group). HF generated by aqueous system. 
$1.5 \mu \mathrm{g} / \mathrm{ml}$, respectively. After dialysis these concentrations

were $0.8 \mu \mathrm{g} / \mathrm{ml}, 0.4 \mathrm{ug} / \mathrm{ml}$ and $0.4 \mu \mathrm{g} / \mathrm{ml}$, respectively,

indicating that both ionic and $\Delta F$ were dialyzable.

In general, the effects of both preliminary exposures were similar. Renal injury as measured by kidney weight to body weight ratio or BUN occurred after both exposures. While the increase in BUN was not maximal at 6 hours postexposure, nearly a 3 fold increase in this plasma component had occurred by this time. Increases in the lung water content occurred following both exposures. Following either exposure the increase was maximal in the 6 hour postexposure group. Exposure to HF resulted in marked increased in the fluoride concentrations in all tissues analyzed: lung, plasma and kidney. In all tissues a fluoride component which did not respond to the fluoride ion sensitive electrode was present. The concentration of the fluoride in this fraction was increased significantly by exposure to HF. Finally, the difficulties encountered in the generation of HF atmospheres by the aqueous system pointed out the necessity of developing another method for generating an HF atmosphere.

B. Dose Response Experiment

The next series of exposures were performed to investigate dose response relationships between HF exposure, tissue fluoride concentration (both total and ionic) and pulmonary or renal toxicity. Groups of 6 male Long Evans rats were exposed to various concentrations of $\mathrm{HF}$ for 6 hours in the modified pickle jar chamber. HF atmospheres were generated by the compressed gas 
technique. The time weighted average airborne fluoride concentrations for these exposures were $11,27,72,116,148$ or 179 $\mathrm{mg} F / \mathrm{m}^{3}$. Rats were sacrificed 6 hours after the end of exposure to allow time for pulmonary and renal damage to develop. Total and ionic fluoride concentrations were determined in lung, plasma and kidney of exposed and control rats. In the course of the experiment two control groups of six rats each were sacrificed 6 hours after a 6 hour exposure to clean room air in a 28 liter glass battery jar inhalation chamber. Total airflow rates were similar in control and HF exposures. All animals, control and exposed, had access to water but not food during the postexposure period. No food or water was present in either exposure chamber.

The airborne fluoride concentration measured at several times during each exposure are shown in Figure 6. As can be seen at lower levels the chamber fluoride concentrations were relatively steady, however at higher levels the airborne fluoride concentrations were quite variable.

No observations of animal behavior during these $\mathrm{HF}$ exposures could be made because the modified exposure chamber was opaque. No gross effects were noted during the postexposure period in either control rats or rats exposed to $116 \mathrm{mg} \mathrm{F} / \mathrm{m}^{3} \mathrm{HF}$ or less. No mortality occurred and no gross pathologic alterations were seen upon necropsy of these animals.

Exposure to 148 or $179 \mathrm{mg} \mathrm{F} / \mathrm{m}^{3} \mathrm{HF}$ resulted in $100 \%$ lethality. Four of the 6 rats exposed to $179 \mathrm{mg} \mathrm{F} / \mathrm{m}^{3}$ died during the exposure; the other two succumber within the firet two hours 
FIGURE 6

Measured airborne fluoride concentration versus exposure time for the $11,27,72,116,148$ and $179 \mathrm{mg} \mathrm{F} / \mathrm{m}^{3} \mathrm{HF}$ dose-response exposures to Blue Spruce rats. 


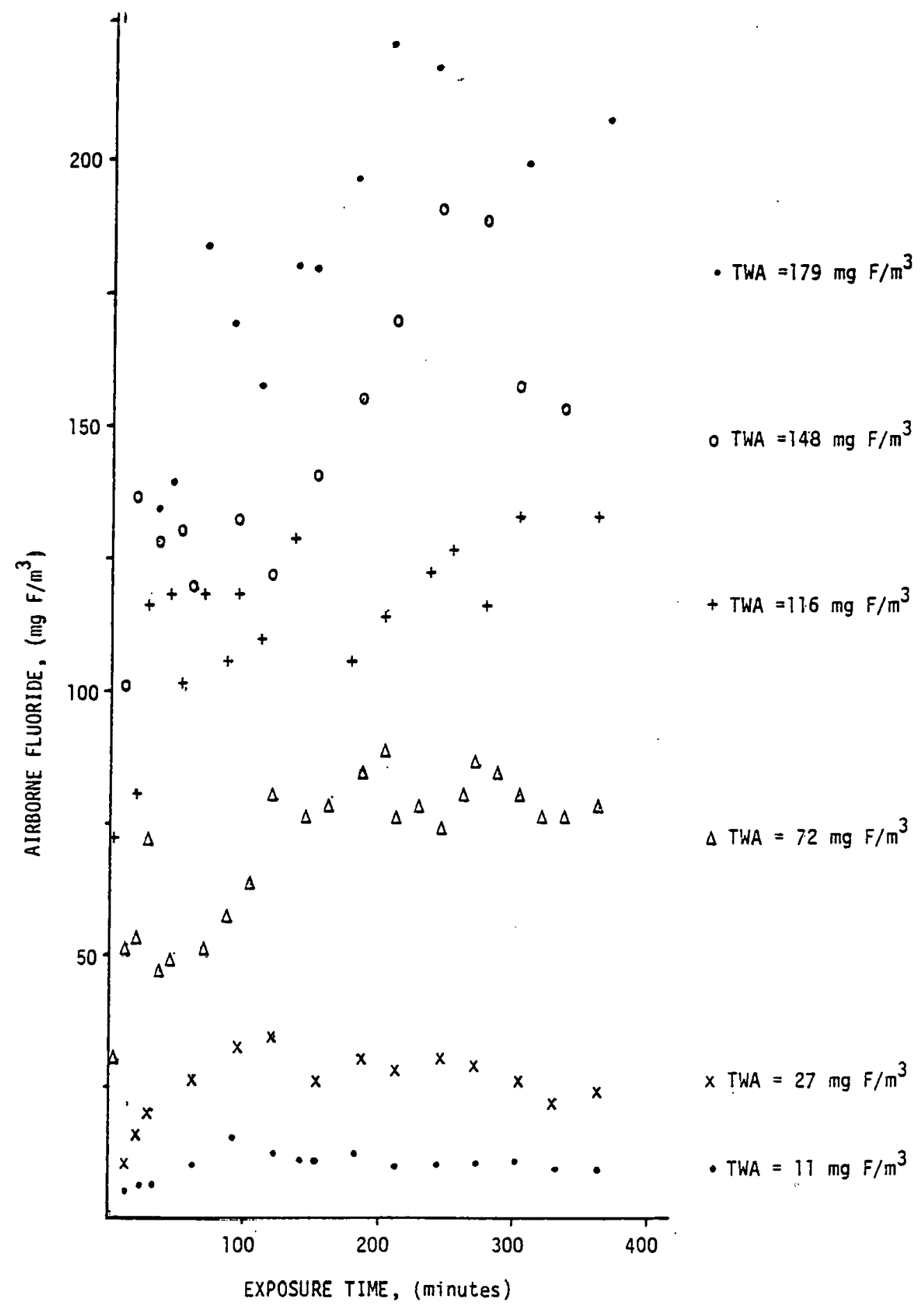


postexposure. All rats exposed to $148 \mathrm{mg} \mathrm{F} / \mathrm{m}^{3} \mathrm{HF}$ died during the first 3 hours of the postexposure period. These animals were necropsied within ten minutes of death. All animals dying in the postexposure period took several deep abdominal breaths just prior to death. In two rats (both exposed to $116 \mathrm{mg} \mathrm{F} / \mathrm{m}^{3}$ ) a yellow mucoid fluid was discharged from the nares. Upon necropsy the lungs of all animals exposed to $148 \mathrm{mg} \mathrm{F} / \mathrm{m}^{3}$ or $179 \mathrm{mg} \mathrm{F} / \mathrm{m}^{3}$ were hemorrhagic in appearance.

The pulmonary effects of exposure to 11 to $179 \mathrm{mg} \mathrm{F} / \mathrm{m}^{3}$ are given in Table 13. Since the lung weight to body weight ratio and the lung wet weight to dry weight ratio were similar in both control groups, the data were pooled to give one control group value. The lung weight to body weight ratio was not significantly altered in rats exposed to any concentration of HF. After no exposure was the lung wet weight to dry weight ratio increased; in fact this ratio was significantly lower than control levels in rats exposed to $148 \mathrm{mg} \mathrm{F} / \mathrm{m}^{3}$. The mean lung wet weight to dry weight ratio in rats exposed to $179 \mathrm{mg} \mathrm{F} / \mathrm{m}^{3}$ was lower than in rats exposed to $148 \mathrm{mg} \mathrm{F} / \mathrm{m}^{3}$ but because of the large standard error of this group the value was not significantly lower than control levels. To investigate the effects of death on this pulmonary parameter male Long Evans rats were sacrificed with pentobarbital and necropsied 10 minutes after the cessation of heartbeat. The lung wet weight to $d r y$ weight ratio in these post mortem control animals was similar to the ratio in the normal control rats. These data are discussed in greater detail below. 
PULMONARY EFFECTS OF EXPOSURE TO 11, 27, 72, 116, 148 or $179 \mathrm{mgF} / \mathrm{m}^{3}$ HF FOR 6 HOURS ${ }^{1}$

\begin{tabular}{|c|c|c|c|c|}
\hline $\begin{array}{c}\text { Airborne } \\
\mathrm{HF} \\
\left(\mathrm{mg} \mathrm{F} / \mathrm{m}^{3}\right)\end{array}$ & $\begin{array}{l}\text { Body Wt. } \\
\text { (g) }\end{array}$ & $\begin{array}{l}\text { Lung Wt. } \\
\text { Body Wt. } \\
(\mathrm{g} / \mathrm{kg})\end{array}$ & $\begin{array}{l}\text { Lung } \\
\text { Wet. Wt. } \\
\text { Dry Wt. }\end{array}$ & $\begin{array}{c}\text { Mortality } \\
\text { no. dead/no. exposed }\end{array}$ \\
\hline Control & $\begin{array}{r}283 \\
6 \\
(12)\end{array}$ & $\begin{array}{l}4.41 \\
.10 \\
(10)\end{array}$ & $\begin{array}{l}4.72 \\
.04 \\
(10)\end{array}$ & $0 / 12$ \\
\hline $11 \mathrm{mg} \mathrm{F} / \mathrm{m}^{3}$ & $\begin{array}{r}294 \\
3 \\
(6)\end{array}$ & $\begin{array}{r}4.21 \\
.06 \\
(5)\end{array}$ & $\begin{array}{r}4.74 \\
.03 \\
(5)\end{array}$ & $0 / 6$ \\
\hline $27 \mathrm{mg} F / \mathrm{m}^{3}$ & $\begin{array}{r}259 \\
3 \\
(6)\end{array}$ & $\begin{array}{r}4.30 \\
.08 \\
(5)\end{array}$ & $\begin{array}{r}4.57 \\
.06 \\
(5)\end{array}$ & $0 / 6$ \\
\hline $72 \mathrm{mg} F / \mathrm{m}^{3}$ & $\begin{array}{r}266 \\
6 \\
(6)\end{array}$ & $\begin{array}{r}4.53 \\
.22 \\
(5)\end{array}$ & $\begin{array}{r}4.60 \\
.12 \\
(5)\end{array}$ & $0 / 6$ \\
\hline $116 \mathrm{mg} \mathrm{F} / \mathrm{m}^{3}$ & $\begin{array}{r}315 \\
6 \\
(6)\end{array}$ & $\begin{array}{r}4.53 \\
.08 \\
(5)\end{array}$ & $\begin{array}{r}4.89 \\
.13 \\
(5)\end{array}$ & $0 / 6$ \\
\hline $148 \mathrm{mg} \mathrm{F} / \mathrm{m}^{3}$ & $\begin{array}{r}353 \\
9 \\
(6)\end{array}$ & $\begin{array}{r}4.50 \\
.28 \\
(5)\end{array}$ & $\begin{array}{c}4.49^{a} \\
.08 \\
(5)\end{array}$ & $6 / 6$ \\
\hline $179 \mathrm{mg} \mathrm{F} / \mathrm{m}^{3}$ & $\begin{array}{r}333 \\
5 \\
(6)\end{array}$ & $\begin{array}{r}5.00 \\
.34 \\
(5)\end{array}$ & $\begin{array}{r}4.34 \\
.18 \\
(5)\end{array}$ & $6 / 6$ \\
\hline
\end{tabular}

1 Values expressed as mean, S.E.M., (number of animals per group). HF generated by compressed gas technique

a $\quad p<0.05$ compared to control 
Lung sections from 5 rats per sacrifice group were examined by light microscopy. Chronic inflammatory disease as evidenced by peribronchial and perivascular lymphocyte accumulation and septal wall thickening was present in every lung section examined (Figure 7). The severity of the disease was ranked in a blind fashion on a scale of 4. No correlation was evident between $\mathrm{HF}$ exposure and the severity of this disease. The scores for groups of control and exposed rats were similar. No pulmonary edema as evidenced by alveolar flooding was observed in any lung section.

The renal effects of exposure to $11-116 \mathrm{mg} \mathrm{F} / \mathrm{m}^{3}$ are given in Table 14. Light microscopic examination of the renal cortices in kidney sections prepared from 5 rats per sacrifice group revealed injury to the proximal tubular epithelium. The principal sign of injury was nuclear pyknosis (Figure 8). Cells containing pyknotic nuclei also tended to be more eosinophilic than neighboring cells with normal appearing nuclei. This injury was scored in a blind fashion on a scale of 4 with a score of 0 indicating normal appearance, a score of 1 indicating the presence of a few cells exhibiting pyknosis, a score of 2 indicating several tubules contained pynotic cells and a score of 3 indicating most of the proximal tubules examined contained injured cells. This renal injury increased in severity with increasing airborne HF exposure concentration. If rats exposed to 148 or $179 \mathrm{mg} \mathrm{F} / \mathrm{m}^{3}$ had survived the entire postexposure period there would have been more time for the development of this morphologic lesion. Perhaps a greater degree of injury would have been present were this to occur. 


\section{FIGURE 7}

Light micrograph of lung from a control (top) and HF exposed (116 mg F/m $\mathrm{m}^{3}$, bottom) rat. Note peribronchial accumulation of lymphocytes (arrows) and septal wall thickening. This disease process appears to be more severe in the exposed rat lung, but this does not represent a trend. The severity of the disease was ranked in a blind fashion; the scores in groups of control or exposed rats were similar. (X 441, hematoxylin and eosin) 


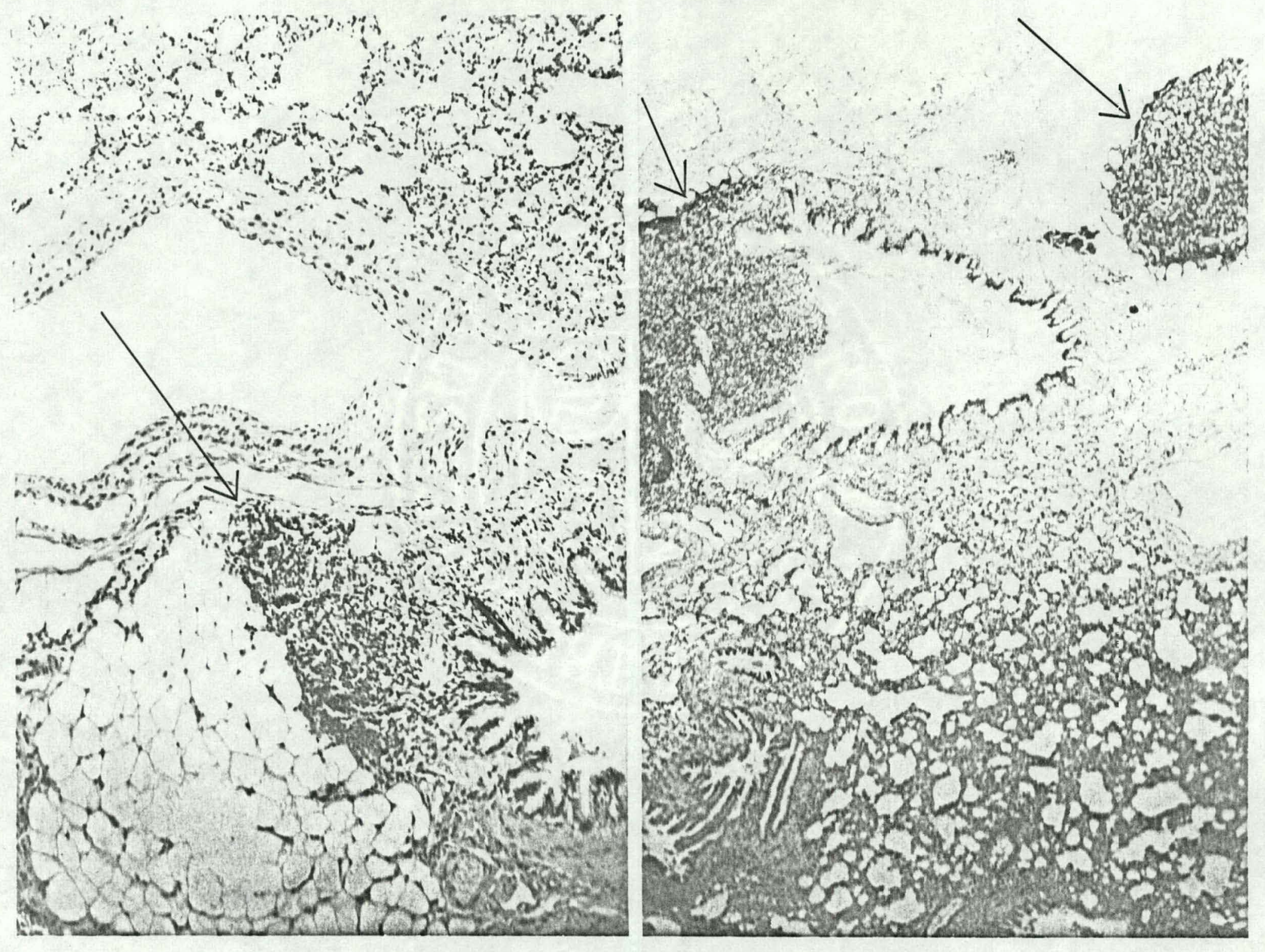


TABLE 14

RENAL EFFECTS OF EXPOSURE TO 11, 27, 72, 116, 148 or $179 \mathrm{mgG} / \mathrm{m}^{3}$ HF FOR 6 HOURS 1

\begin{tabular}{|c|c|c|c|c|c|c|c|}
\hline$\underset{H G}{\text { Airborne }}$ & Body Wt. & $\frac{\text { Kidney Wt. }}{\text { Body Wt. }}$ & $\begin{array}{l}\text { BUN } \\
(\mathrm{mg} \%)\end{array}$ & \multicolumn{4}{|c|}{$\begin{array}{l}\text { Kidney Pathology } 2 \\
\text { Range of Scores (Median Score) }\end{array}$} \\
\hline Control & $\begin{array}{c}283 \\
6 \\
(12)\end{array}$ & $\begin{array}{c}7.61 \\
.10 \\
(12)\end{array}$ & $(12)^{10.1}$ & & $0-0$ & 0 & 0 \\
\hline $11 \mathrm{mg} \mathrm{F} / \mathrm{m}^{3}$ & $\begin{array}{r}294 \\
3 \\
(6)\end{array}$ & $\begin{array}{r}7.39 \\
.22 \\
(6)\end{array}$ & $\begin{array}{r}10.5 \\
.5 \\
(6)\end{array}$ & & $0-0$ & 0 & 0 \\
\hline $27 \mathrm{mg} \mathrm{F} / \mathrm{m}^{3}$ & $\begin{array}{r}259 \\
3 \\
(6)\end{array}$ & $\begin{array}{r}7.66 \\
.22 \\
(6)\end{array}$ & $\begin{array}{c}12.1^{b} \\
.^{b}(6)\end{array}$ & & $0-0$ & 0 & 0 \\
\hline $72 \mathrm{mg} \mathrm{F} / \mathrm{m}^{3}$ & $\begin{array}{r}266 \\
6 \\
(6)\end{array}$ & $\begin{array}{r}7.96 \\
.34 \\
(6)\end{array}$ & $\begin{array}{c}23.6^{\mathrm{b}} \\
2.5 \\
(6)\end{array}$ & & $0-2$ & 1 & 1 \\
\hline $116 \mathrm{mg} \mathrm{F} / \mathrm{m}^{3}$ & $\begin{array}{r}315 \\
6 \\
(6)\end{array}$ & $\begin{array}{r}8.04 \\
.28 \\
(6)\end{array}$ & $\begin{array}{c}62.2^{b} \\
4.3^{3} \\
(6)\end{array}$ & & $1-2$ & 1 & 1 \\
\hline $148 \mathrm{mg} \mathrm{F} / \mathrm{m}^{3}$ & $\begin{array}{r}353 \\
9 \\
(6)\end{array}$ & $\begin{array}{r}7.71 \\
.26 \\
(6)\end{array}$ & -- & & $2-3$ & 2 & 2 \\
\hline $179 \mathrm{mg} \mathrm{F} / \mathrm{m}^{3}$ & $\begin{array}{r}333 \\
5 \\
(6)\end{array}$ & $\begin{array}{r}7.93 \\
.25 \\
(6)\end{array}$ & -- & & $0-3$ & 2 & 2 \\
\hline
\end{tabular}


Footnotes to Table 14

1 Values expressed as mean, S.E.M., (number of animals per group). HF generated by compressed gas technique.

2 Kidney sections from 5 animals per group were examined by light microscopy; the only pathologic change attributable to HF, proximal tubular injury as evidence by nuclear pyknosis was rated on a scale of 4 with 0 representing normal appearance and 4 representing severe damage.

b $p<0.01$ compared to control. 
FIGURE 8

Light micrograph of kidney from a control (top) and HF exposed (116 $\mathrm{mg} \mathrm{F} / \mathrm{m}^{3}$, bottom) rat. Note condensed darkly stained nuclei (pyknotic nuclei, a few shown by arrows) in proximal tubular epithelium of the exposed rat kidney. The severity of the injury in this kidney was ranked 1 on a scale of 4 , see text for explanation of ranking. ( $X$ 441, hematoxylin and eosin) 

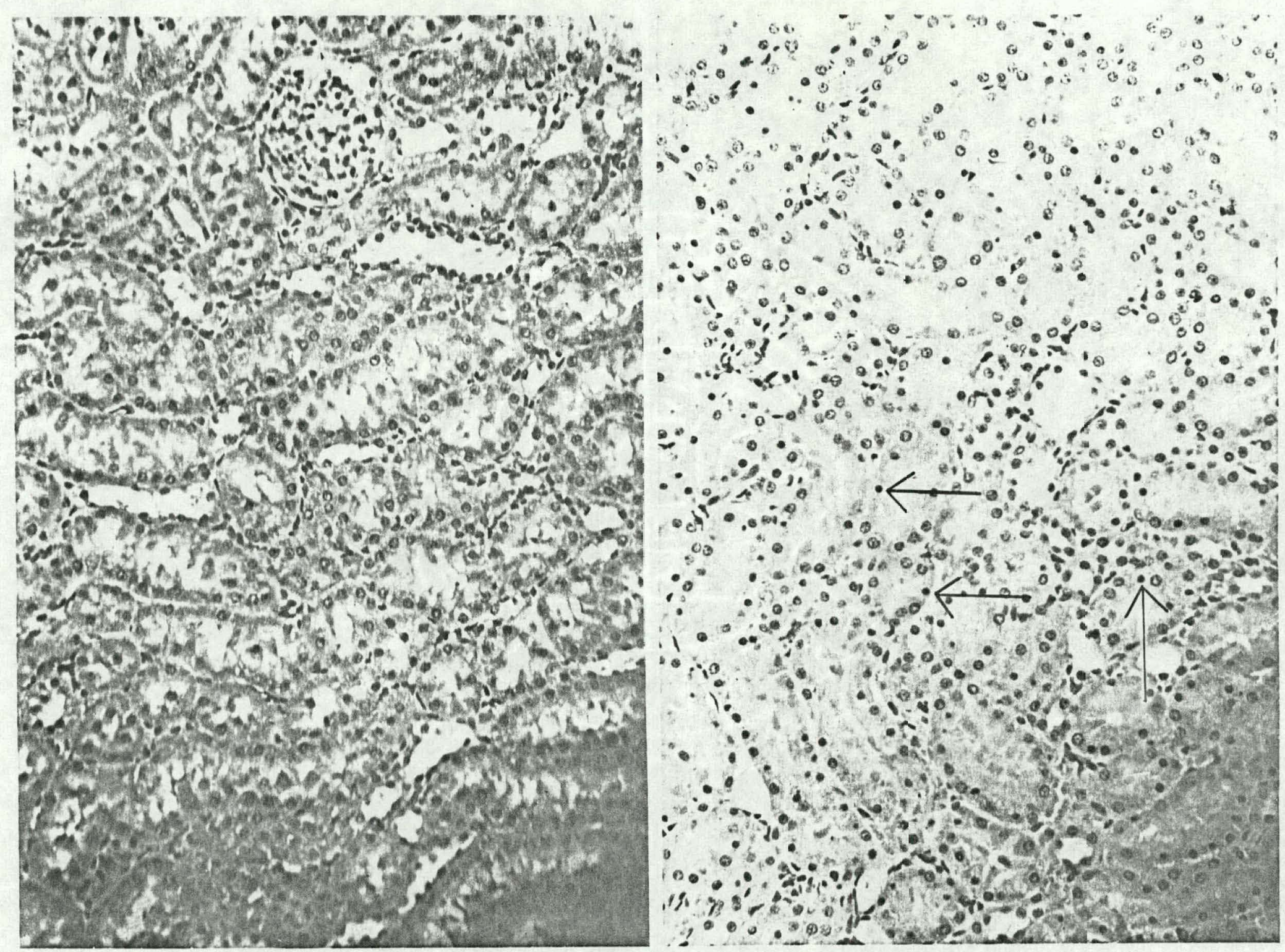
In no exposure group was the kidney weight to body weight ratio significantly different from control levels. BUN was significantly increased by exposure to 27,72 or $116 \mathrm{mg} \mathrm{F} / \mathrm{m}^{3} \mathrm{HF}$. The BUN increased consistently with increasing airborne HF concentration suggesting a dose response relationship. In Figure 9, BUN is plotted versus the log of the plasma ionic fluoride concentration in these rats. As is evident, BUN increases with increasing plasma fluoride concentration once fluoride levels of $2 \mu \mathrm{g} / \mathrm{ml}$ are reached, again suggesting a dose response relationship. A similar relationship exists between BUN and ionic kidney fluoride concentration (data not shown).

The total and ionic fluoride concentrations in soft tissues of rats after exposure to $11-179 \mathrm{mg} \mathrm{F} / \mathrm{m}^{3} \mathrm{HF}$ are given in Table 15 . Total and ionic fluoride concentrations in lung, plasma and kidney were elevated in all HF exposed groups. In these three soft tissues both total and ionic fluoride concentrations increased with increasing airborne fluoride concentration indicating a cause and effect relationship. The mean ionic fluoride concentration in lungs and kidney of rats exposed to $11,27,72$ or $116 \mathrm{mg} F / \mathrm{m}^{3}$ are plotted linearly against the mean plasma ionic fluoride concentration in these rats, in Figure 10. A significant correlation exists between ionic lung and plasma fluoride ( $r=$ 9999, df $=2, p<0.01)$. The data from all four exposure groups fit this curve. In these animals the lung ionic fluoride concentration exceeded the plasma ionic fluoride concentration by a factor of $2.6-3.2$. When the data for all 4 exposure groups are 
FIGURE 9

BUN versus log plasma ionic fluoride concentration following exposure to $11,27,72$ or $116 \mathrm{mg} \mathrm{F} / \mathrm{m}^{3} \mathrm{HF}$ (closed circles) or $111 \mathrm{mg} \mathrm{F} / \mathrm{m}^{3} \mathrm{HF}$ plus water vapor (X's). 


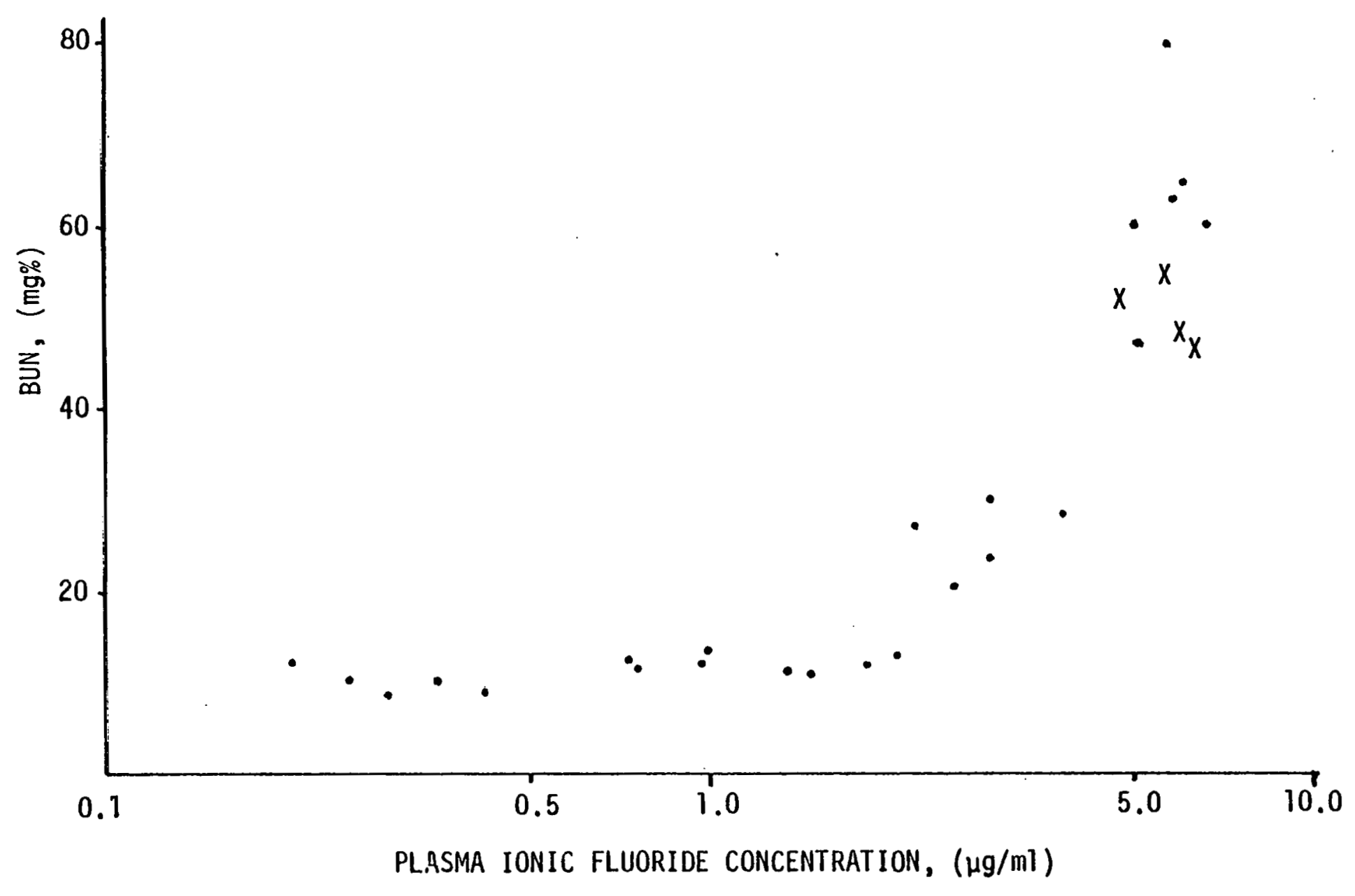


MEASURED FLUORIDE CONCENTRATIONS IN SOFT TISSUES OF RATS EXPOSED TO 11, 27, 72, 116, 148 or $179 \mathrm{mg} \mathrm{F} / \mathrm{m}^{3}$ HF FOR 6 HOURS 1

\begin{tabular}{|c|c|c|c|c|c|c|}
\hline $\begin{array}{r}\text { Airborne } \mathrm{HF} \\
\left(\mu \mathrm{g} \mathrm{F} / \mathrm{m}^{3}\right)\end{array}$ & $\begin{array}{r}\text { Lu } \\
\text { (pg } \\
\text { Total }\end{array}$ & $\begin{array}{l}g \\
\text { g) } \\
\text { Ionic }\end{array}$ & $\begin{array}{l}\text { Plas } \\
\text { ( } \mu \mathrm{g} / \\
\text { Total }\end{array}$ & $\begin{array}{l}\text { i) } \\
\text { Ionic }\end{array}$ & $\begin{array}{c}\text { Kidr } \\
\text { Thg/S } \\
\text { Total }\end{array}$ & )$_{\text {Ionic }}^{\text {ey }}$ \\
\hline Contro $1^{2}$ & $\begin{array}{r}0.1 \\
.5\end{array}$ & $\begin{array}{r}0.05 \\
.03\end{array}$ & $\begin{array}{r}0.04 \\
.12\end{array}$ & $\begin{array}{r}0.032 \\
.034\end{array}$ & $\begin{array}{r}0.3 \\
.5\end{array}$ & $\begin{array}{r}0.08 \\
.03\end{array}$ \\
\hline $11 \mathrm{mg} F / \mathrm{m}^{3}$ & $\begin{array}{l}1.6 \\
.3 \\
(5)\end{array}$ & $\begin{array}{r}1.49 \\
.32 \\
(5)\end{array}$ & $\begin{array}{r}0.68 \\
.21 \\
(6)\end{array}$ & $\begin{array}{r}0.57 \\
.19 \\
(6)\end{array}$ & $\begin{array}{l}1.8 \\
.3 \\
(6)\end{array}$ & $\begin{array}{r}1.45 \\
.26 \\
(6)\end{array}$ \\
\hline $27 \mathrm{mg} F / \mathrm{m}^{3}$ & $\begin{array}{l}3.2 \\
.3 \\
(5)\end{array}$ & $\begin{array}{r}2.98 \\
.27 \\
(5)\end{array}$ & $\begin{array}{r}1.24 \\
.24 \\
(6)\end{array}$ & $\begin{array}{r}1.03 \\
.21 \\
(6)\end{array}$ & $\begin{array}{l}3.0 \\
.7 \\
(\dot{6})\end{array}$ & $\begin{array}{r}2.98 \\
.69 \\
(6)\end{array}$ \\
\hline $72 \mathrm{mg} F / \mathrm{m}^{3}$ & $\begin{array}{r}9.1 \\
.9 \\
(5)\end{array}$ & $\begin{array}{r}8.62 \\
.86 \\
(5)\end{array}$ & $\begin{array}{r}3.08 \\
.26 \\
(6)\end{array}$ & $\begin{array}{r}2.72 \\
.27 \\
(6)\end{array}$ & $\begin{array}{l}9.0 \\
1.3 \\
(6)\end{array}$ & $\begin{array}{r}7.41 \\
.95 \\
(6)\end{array}$ \\
\hline $116 \mathrm{mg} \mathrm{F} / \mathrm{m}^{3}$ & $\begin{array}{l}19 . \\
2.2 \\
(5)\end{array}$ & $\begin{array}{c}18.1 \\
1.9 \\
(5)\end{array}$ & $\begin{array}{r}6.21 \\
.37 \\
(6)\end{array}$ & $\begin{array}{r}5.73 \\
.26 \\
(6)\end{array}$ & $\begin{array}{r}14 . \\
1.3 \\
(6)\end{array}$ & $\begin{array}{r}10.4 \\
.9 \\
(6)\end{array}$ \\
\hline $148 \mathrm{mg} \mathrm{F} / \mathrm{m}^{3}$ & $\begin{array}{l}23 . \\
1.5 \\
(5)\end{array}$ & $\begin{array}{r}22.6 \\
1.5 \\
(5)\end{array}$ & -- & - & $\begin{array}{r}21 . \\
2.7 \\
(5)\end{array}$ & $\begin{array}{r}20.3 \\
2.7 \\
(5)\end{array}$ \\
\hline $179 \mathrm{mg} \mathrm{F} / \mathrm{m}^{3}$ & $\begin{array}{l}27 . \\
2.1 \\
(5)\end{array}$ & $\begin{array}{r}23.4 \\
2.4 \\
(5)\end{array}$ & -- & -- & $\begin{array}{r}18 . \\
1.4 \\
(6)\end{array}$ & $\begin{array}{r}17.2 \\
1.5 \\
(6)\end{array}$ \\
\hline
\end{tabular}

1 Values expressed as mean, S.E.M., (number of animals per group). HF generated by compressed gas technique.

2 Tissues from control rats were pooled by group ( 6 rats per group) prior to analysis. The values shown are the concentrations measured in the tissue pools of the two control groups sacrificed. 
FIGURE 10

Lung and kidney ionic fluoride concentration versus plasma ionic fluoride concentration following exposure to $11,27,72$ or

$116 \mathrm{mg} \mathrm{F} / \mathrm{m}^{3} \mathrm{HF}$. The lines represent plus or minus one S.E.M. and intersect at the mean of each group. 

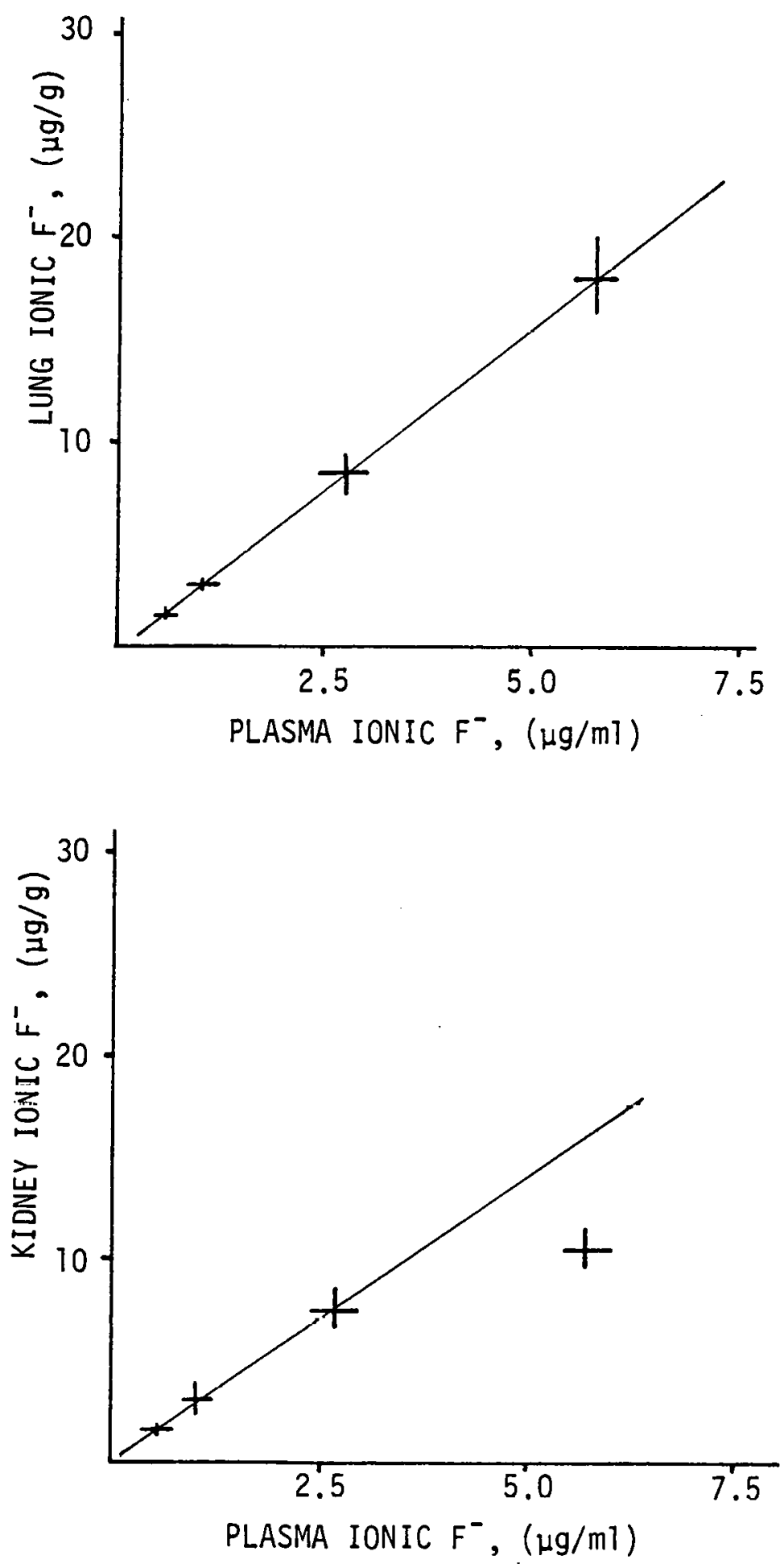
considered, a linear relationship between kidney and plasma ionic fluoride concentration is not evident. However, the kidney and plasma fluoride concentrations in the rats exposed to the three lower concentrations 11,27 or $72 \mathrm{mg} \mathrm{F} / \mathrm{m}^{3}$ are significantly correlated $(r=.999, d f=1 p<.05)$. The values in rats exposed to $116 \mathrm{mg} \mathrm{F} / \mathrm{m}^{3}$ fall below the straight line defined by the three lower doses. Similar relationships exist between lung and kidney total fluoride concentration and plasma total fluoride concentration but the ionic data are shown because the ionic fluoride analytical method is more sensitive and precise than the total fluoride method.

As in rats exposed to HF generated by the aqueous system, total fluoride concentration exceeded ionic fluoride concentration in the rats exposed to $\mathrm{HF}$ generated by the compressed gas technique. The difference between total and ionic fluoride concentration was of a smaller magnitude in these rats (Table 16).

The $\Delta F$ concentration was obtained by calculation on lung samples from 30 rats exposed to $\mathrm{HF}$ in the dose-response experiment. Of these lung samples, 24 contained positive $\Delta \mathbf{F}$ concentrations, 5 contained negative $\Delta F$ concentrations and one sample contained a $\Delta F$ concentration of zero. Application of the sign test indicated that the probability of this many positive values occurring by chance was less than 18 . On the basis of the mean and standard error of the $\Delta F$ concentration in lungs of animals from each exposure group, statistically significant levels of $\Delta F$ were present only in animals exposed to 27 or $179 \mathrm{mg} \mathrm{F} / \mathrm{m}^{3} \mathrm{HF}$. 
TABLE 16

$\triangle F$ CONCENTRATIONS IN SOFT TISSUES OF RATS EXPOSED

TO $11,27,72,116,148$ or $179 \mathrm{mg} \mathrm{F} / \mathrm{m}^{3} \mathrm{HF}$ FOR 6 HOURS 1

\begin{tabular}{|c|c|c|c|c|c|c|c|}
\hline \multirow[t]{2}{*}{$\begin{array}{l}\text { Airborne HF } \\
\left(\mathrm{mg} \mathrm{F} / \mathrm{m}^{3}\right)\end{array}$} & \multicolumn{2}{|c|}{$\begin{array}{c}\text { Lung } \\
(\mu \mathrm{g} / \mathrm{g})\end{array}$} & \multicolumn{3}{|c|}{$\begin{array}{r}\text { Pl asma } \\
(\mu \mathrm{g} / \mathrm{ml})\end{array}$} & \multicolumn{2}{|c|}{$\begin{array}{l}\text { Kidney } \\
(\mu g / g)\end{array}$} \\
\hline & & $\Delta F$ & Total & $\Delta \mathrm{F}$ & $\% \Delta \mathrm{F}$ & Tota & $\Delta \mathrm{F}$ \\
\hline Control2 & $\begin{array}{l}0.1 \\
0.5\end{array}$ & $\begin{array}{l}0.1 \\
0.5\end{array}$ & $\begin{array}{l}.04 \\
.12\end{array}$ & $\begin{array}{l}.01 \\
.09\end{array}$ & & $\begin{array}{r}0.3 \\
.5\end{array}$ & $\begin{array}{r}0.2 \\
.5\end{array}$ \\
\hline $11 \mathrm{mg} F / \mathrm{m}^{3}$ & $\begin{array}{l}1.6 \\
.3 \\
(5)\end{array}$ & $\begin{array}{l}0.1 \\
0.1 \\
(5)\end{array}$ & $\begin{array}{l}.68 \\
.21 \\
(6)\end{array}$ & $\begin{array}{l}.11 \\
.03 \\
(6)\end{array}$ & $\begin{array}{c}17 \\
3 \\
(6)\end{array}$ & $\begin{array}{l}1.8 \\
.3 \\
(6)\end{array}$ & $\begin{array}{l}0.3 \\
.1 \\
(6)\end{array}$ \\
\hline $27 \mathrm{mg} F / \mathrm{m}^{3}$ & $\begin{array}{l}3.2 \\
.3 \\
(5)\end{array}$ & $\begin{array}{l}0.2 \\
\dot{1} \\
(5)\end{array}$ & $\begin{array}{r}1.24 \\
.24 \\
(6)\end{array}$ & $\begin{array}{l}.21 \\
.05 \\
(6)\end{array}$ & $\begin{array}{r}18 \\
3 \\
(6)\end{array}$ & $\begin{array}{l}3.0 \\
.7 \\
(\dot{6})\end{array}$ & $\begin{array}{l}0.0 \\
.1 \\
(\dot{6})\end{array}$ \\
\hline $72 \mathrm{mg} F / \mathrm{m}^{3}$ & $\begin{array}{l}9.1 \\
(5) \\
(5)\end{array}$ & $\begin{array}{l}0.5 \\
\dot{2} \\
(5)\end{array}$ & $\begin{array}{r}3.08 \\
.26 \\
(6)\end{array}$ & $\begin{array}{l}.36 \\
.10 \\
(6)\end{array}$ & $\begin{array}{r}12 \\
3 \\
(6)\end{array}$ & $\begin{array}{l}9.0 \\
1.3 \\
(6)\end{array}$ & $\begin{array}{r}1.6 \\
.8 \\
(6)\end{array}$ \\
\hline $116 \mathrm{mg} \mathrm{F} / \mathrm{m}^{3}$ & $\begin{array}{l}19 . \\
2.2 \\
(5)\end{array}$ & $\begin{array}{r}0.6 \\
\dot{4} \\
(5)\end{array}$ & $\begin{array}{r}6.21 \\
.37 \\
(6)\end{array}$ & $\begin{array}{l}.48 \\
.16 \\
(6)\end{array}$ & $\begin{array}{r}7 \\
2 \\
(6)^{2}\end{array}$ & $\begin{array}{c}14 . \\
1.3 \\
(6)\end{array}$ & $\begin{array}{r}3.3 \\
.7 \\
(6)\end{array}$ \\
\hline $148 \mathrm{mg} \mathrm{F} / \mathrm{m}^{3}$ & $\begin{array}{l}23 . \\
1.5 \\
(5)\end{array}$ & $\begin{array}{r}0.3 \\
.6 \\
(5)\end{array}$ & -- & -- & -- & $\begin{array}{l}21 . \\
2.7 \\
(5)\end{array}$ & $\begin{array}{l}0.4 \\
.2 \\
(5)\end{array}$ \\
\hline $179 \mathrm{mg} \mathrm{F} / \mathrm{m}^{3}$ & $\begin{array}{l}27 . \\
2.1 \\
(5)\end{array}$ & $\begin{array}{r}3.4 \\
.4 \\
(5)\end{array}$ & -- & -- & -- & $\begin{array}{l}18 . \\
1.4 \\
(6)\end{array}$ & $\begin{array}{r}1.2 \\
(6)\end{array}$ \\
\hline
\end{tabular}

1 Values expressed as mean, S.E.M., (number of animals per group).

2 Tissues from control rats were pooled by group ( 6 rats per group) prior to analysis. The values shown are the concentrations determined in the tissue pools of the two control groups sacrificed. 
Statistically significant levels of $\Delta F$ were present in the kidneys of rats exposed to 11,116 or $179 \mathrm{mg} \mathrm{F} / \mathrm{m}^{3} \mathrm{HF}$. Of the 35 kidney homogenates analyzed, 28 contained positive $\Delta F$ concentrations, 2 contained negative $\Delta F$ concentrations and 4 contained a $\Delta F$ concentration of zero. The probability of the number of positive values occurring by chance again is less than 18 . Statistically significant levels of $\Delta F$ were present in the plasma of rats exposed to $11,27,72$ and $116 \mathrm{mg} \mathrm{F} / \mathrm{m}^{3}$. Of the 24 plasma samples analyzed, I contained no $\Delta F(\Delta F$ concentration equal to zero) and 23 contained positive $\Delta F$ concentrations. Again, the probability of this number of positive values occurring by chance is less than 18. The frequency of occurrence of positive $\Delta F$ concentrations in all three tissues analyzed indicates that the detection of $\Delta F$ is not due to random analytical error. In the preliminary experiments it was shown that $\Delta F$ concentrations in lung and kidney change with time after exposure. Since the rats exposed to 148 or $179 \mathrm{mg} \mathrm{F} / \mathrm{m}^{3}$ did not survive the full 6 hour postexposure period the $\Delta F$ concentrations in their tissues may not be directly comparable to those in rats which did survive the entire postexposure period. Thus, only the $\Delta F$ levels in tissues of rats exposed to $116 \mathrm{mg} \mathrm{F} / \mathrm{m}^{3} \mathrm{HF}$ or less should be considered when looking for dose-response relationships. No clear cut dose dependent increase in $\Delta F$ concentration in lung and kidney of HF exposed rats is evident. However, in plasma $\Delta F$ concentrations consistently increased with increasing airborne fluoride concentration. Not only was the plasma $\Delta F$ concentration 
in all groups higher than control levels but the $\Delta F$ concentration in plasma of rats exposed to 72 or $116 \mathrm{mg} \mathrm{F} / \mathrm{m}^{3} \mathrm{HF}$ was significantly ( $p<0.05$ in each case) higher than in plasma of rats exposed to $11 \mathrm{mg} \mathrm{F} / \mathrm{m}^{3} \mathrm{HF}$. Though the significance of the relationship is unclear the concentration of $\Delta F$ in plasma is strongly correlated with the logarithm of the total fluoride concentation in plasma ( $r=0.99997, p<0.01$; Figure 11).

Metabolism cages became available near the end of the dose response experiments and control rats and rats exposed to 11 or 27 $\mathrm{mg} \mathrm{F} / \mathrm{m}^{3} \mathrm{HF}$ were held in these cages ( 3 animals per cage) for the 6 hour postexposure period. The urines excreted by the rats in each group were pooled by group and the ionic fluoride content determined. Rats exposed to 11 or $27 \mathrm{mg} \mathrm{F} / \mathrm{m}^{3}$ excreted an average of 98 or $291 \mu \mathrm{g}$ fluoride, respectively, during this period compared to $5 \mu \mathrm{g}$ excreted by controls.

During the course of the dose-response experiments several male Long Evans rats were obtained from Char les River Laboratories. This was due to an administrative error; the author was unaware of the change of suppliers until several weeks after the completion of the exposures. The data from rats obtained from Charles River Laboratory are treated separately in this section.

Both control and $\mathrm{HF}$ exposures were performed under exactly the same conditions as for Blue Spruce supplied rats. The airborne fluoride concentrations measured at several times during each exposure are shown in Figure 12. The exposures of time weighted average 26 or $54 \mathrm{mg} \mathrm{F} / \mathrm{m}^{3}$ were generated by the compressed gas 


\section{FIGURE 11}

Plasma $\Delta F$ concentration versus log plasma total $F$ concentration of rats exposed to $11,27,72$ or $116 \mathrm{mg} \mathrm{F} / \mathrm{m}^{3} \mathrm{HF}$. The lines represent plus or minus one S.E.M. and intersect at the mean of each group. 


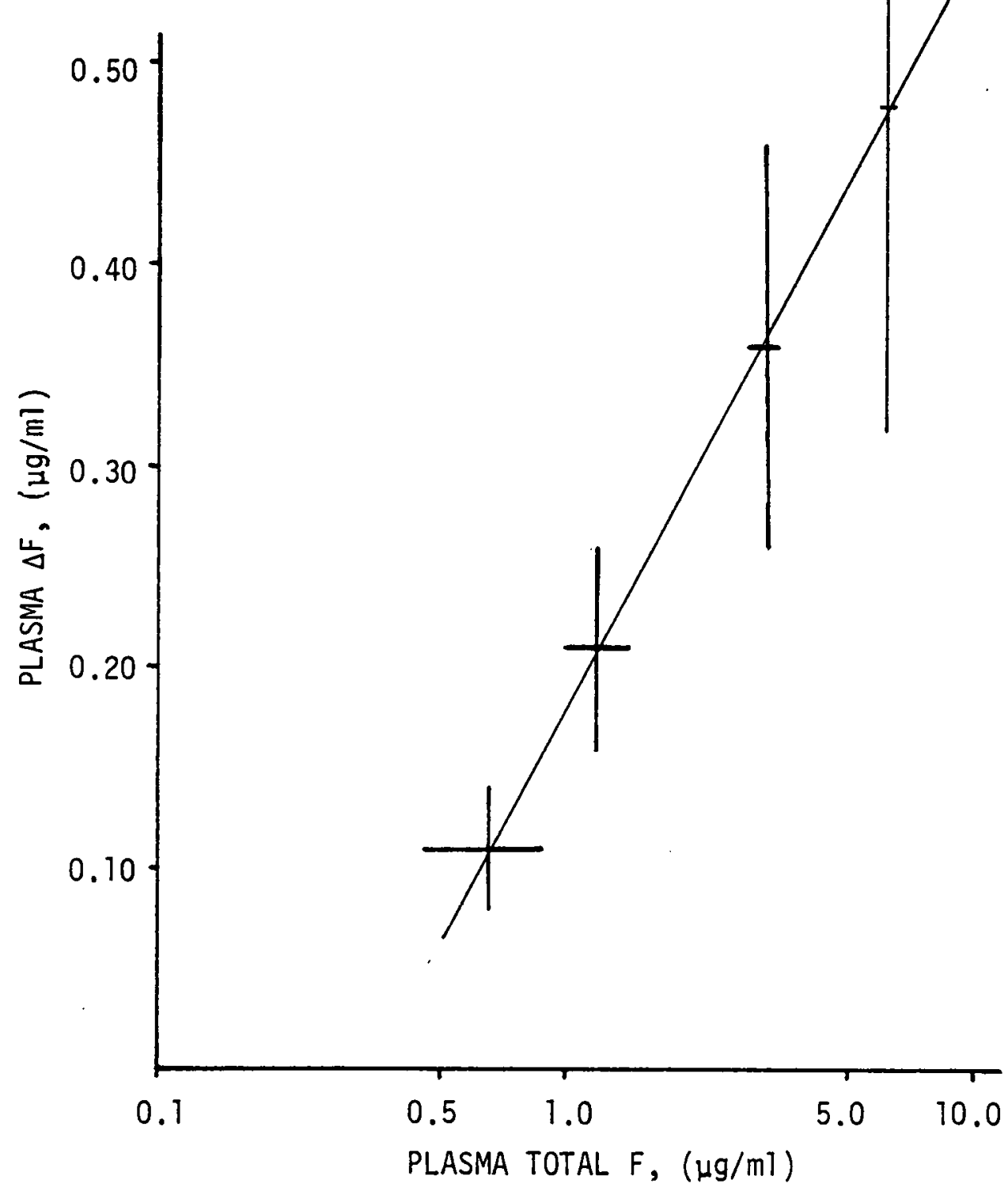


FIGURE 12

Measured airborne fluoride concentration versus exposure time for 26, 54 and $84 \mathrm{mg} \mathrm{F} / \mathrm{m}^{3} \mathrm{HF}$ exposures to Charles River rats. The 26 and $54 \mathrm{mg} \mathrm{F} / \mathrm{m}^{3} \mathrm{HF}$ exposures were generated by the compressed gas technique; the $84 \mathrm{mg} \mathrm{F} / \mathrm{m}^{3} \mathrm{HF}$ exposure by the aqueous system. 


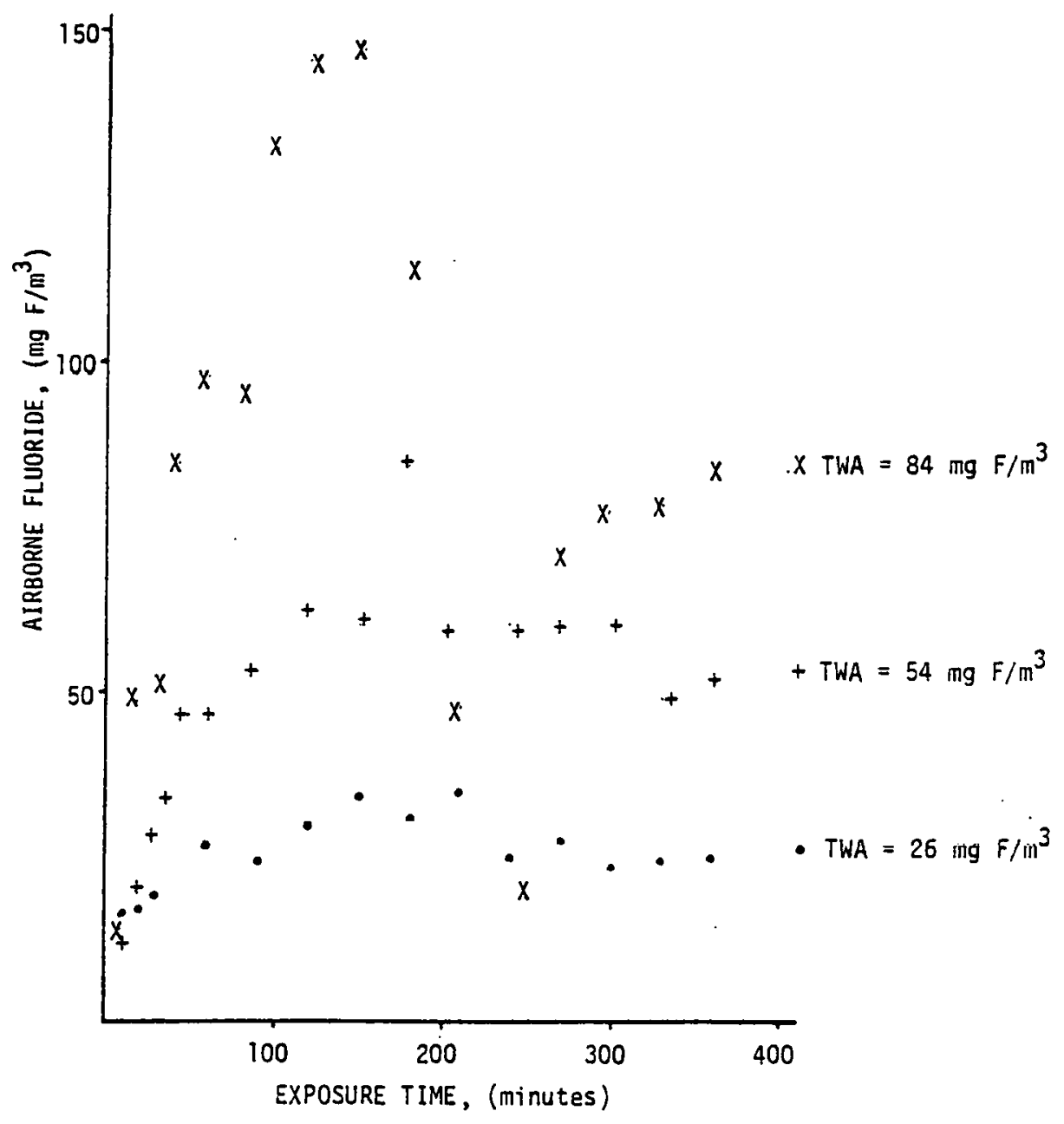


system and were performed to fill out the dose response curve. After it was learned that these rats were obtained from Charles River an exposure of Blue spruce rats to $27 \mathrm{mg} \mathrm{F} / \mathrm{m}^{3} \mathrm{HF}$ was performed to compare with the $26 \mathrm{mg} \mathrm{F} / \mathrm{m}^{3}$ exposure to Charles River rats. For the $84 \mathrm{mg} \mathrm{F} / \mathrm{m}^{3}$ exposure $\mathrm{HF}$ was generated by the aqueous system. This exposure was performed in an attempt to repeat the $55 \mathrm{mg} \mathrm{F} / \mathrm{m}^{3}$ exposure discussed in the preliminary experiments section. As can be seen airborne fluoride concentrations during this exposure were quite variable.

One group of male Long Evans rats obtained from Charles River Laboratories was exposed to room air and sacrificed 6 hours after the end of exposure. This group is the postmortem group referred to earlier. These animals were sacrificed with sodium pentobarbital and necropsied 10 minutes after the cessation of heartbeat to investigate if death had any effects on the pulmonary and renal parameters measured. No blood was withdrawn from these animals, however, in all other respects, necropsies were performed by the normal procedure.

The pulmonary and renal effects in Charles River rats after exposure to HF are given in Table 17. The effects in Blue Spruce rats of exposure to $27 \mathrm{mg} \mathrm{F} / \mathrm{m}^{3}$ are included for comparison. The kidney weight to body weight ratio was similar in all groups, including the Blue Spruce. The BUN in rats following exposure to $54 \mathrm{mg} \mathrm{F} / \mathrm{m}^{3}$ was significantly higher than the BUN following exposure to $26 \mathrm{mg} \mathrm{F} / \mathrm{m}^{3}$ suggesting a dose response relationship in the Charles River rats. The BUN after $84 \mathrm{mg} \mathrm{F} / \mathrm{m}^{3}$ generated by 
TABLE 17

PULMONARY AND RENAL EFFECTS IN CHARLES RIVER RATS OF EXPOSURE

TO 26, 54, or $84 \mathrm{mgF} / \mathrm{m}^{3}$ HF FOR 6 HOURS'

\begin{tabular}{|c|c|c|c|c|c|}
\hline $\begin{array}{l}\text { Exposure Conditions } \\
\text { (generator system) }\end{array}$ & $\begin{array}{l}\text { Body Wt. } \\
\text { (g) }\end{array}$ & $\frac{\text { Lung Wt. }}{\text { Body Wt. }}$ & Lung Wet Wt. & 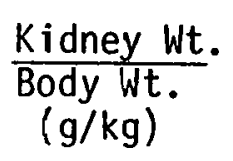 & $\begin{array}{c}\text { BUN } \\
\text { (mg\%) }\end{array}$ \\
\hline Postmortem control & $\begin{array}{r}246 \\
5 \\
(6)\end{array}$ & $\begin{array}{r}4.84 \\
.13 \\
(5)\end{array}$ & $\begin{array}{r}4.68 \\
.03 \\
(5)\end{array}$ & $\begin{array}{r}7.59 \\
.20 \\
(5)\end{array}$ & --- \\
\hline $\begin{array}{l}26 \mathrm{mg} \mathrm{F} / \mathrm{m}^{3} \mathrm{HF} \\
\text { (compressed gas) }\end{array}$ & $\begin{array}{l}289 \\
10 \\
(6)\end{array}$ & $\begin{array}{r}4.30 \\
.11 \\
(5)\end{array}$ & $\begin{array}{r}4.74 \\
.03 \\
(5)\end{array}$ & $\begin{array}{r}7.01 \\
.14 \\
(6)\end{array}$ & $\begin{array}{l}20.9 \\
1.5 \\
(6)\end{array}$ \\
\hline $\begin{array}{l}54 \mathrm{mg} \mathrm{F} / \mathrm{m}^{3} \mathrm{HF} \\
\text { (compressed gas) }\end{array}$ & $\begin{array}{r}273 \\
3 \\
(6)\end{array}$ & $\begin{array}{r}4.22 \\
.14 \\
(5)\end{array}$ & $\begin{array}{r}4.69 \\
.05 \\
(5)\end{array}$ & $\begin{array}{r}8.04 \\
.42 \\
(6)\end{array}$ & $\begin{array}{l}30.6 \\
3.3 \\
(6)\end{array}$ \\
\hline $\begin{array}{l}84 \mathrm{mg} \mathrm{F} / \mathrm{m}^{3} \mathrm{HF} \\
\text { (aqueous system) }\end{array}$ & $\begin{array}{r}334 \\
7 \\
(6)\end{array}$ & $\begin{array}{r}4.36 \\
.08 \\
(5)\end{array}$ & $\begin{array}{r}4.64 \\
.03 \\
(5)\end{array}$ & $\begin{array}{r}6.99 \\
.22 \\
(6)\end{array}$ & $\begin{array}{r}24.7 \\
2.0 \\
(6)\end{array}$ \\
\hline $\begin{array}{l}\text { Blue Spruce Rats } \\
27 \mathrm{mg} \mathrm{F} / \mathrm{m}^{3} \mathrm{HF} \\
\text { (compressed Gas) }\end{array}$ & $\begin{array}{r}259 \\
3 \\
(6)\end{array}$ & $\begin{array}{r}4.30 \\
.08 \\
(5)\end{array}$ & $\begin{array}{r}4.57 \\
.06 \\
(5)\end{array}$ & $\begin{array}{r}7.66 \\
.22 \\
(6)\end{array}$ & $\begin{array}{l}12.7 \\
(6)^{4}\end{array}$ \\
\hline
\end{tabular}

1 Values expressed as mean, S.E.M., (number of animals per group). 
the aqueous system fell midway between these values. The BUN in Charles River rats following exposure to $26 \mathrm{mg} \mathrm{F} / \mathrm{m}^{3}$ was significantly higher than the BUN in Blue Spruce rats following exposure to $27 \mathrm{mg} \mathrm{F} / \mathrm{m}^{3}$. Without the appropriate control data it is impossible to determine if Charles River rats are more sensitive than Blue Spruce rats to HF induced renal damage as measured by increased BUN or if the normal BUN in these animals is higher than in Blue Spruce animals.

No change in the lung wet weight to dry weight ratio was seen following any exposure. The lung weight to body weight ratio was similar in the Blue Spruce rats and in the Charles River rats exposed to 26,54 or $84 \mathrm{mg} \mathrm{F} / \mathrm{m}^{3} \mathrm{HF}$. This ratio was significantly higher in the postmortem control group than in any exposed group. This may be due to entrapped blood since no blood was removed for these animals and the blood contained in the lung constitutes a significant fraction of the total lung weight (Staub, 1974).

The total and ionic fluoride concentrations in soft tissues of exposed and control Charles River rats are given in Table 18. The fluoride concentrations in lung and kidney of the postmortem control group were similar to concentrations observed in Blue Spruce control rats (Table 15). In all tissues both total and ionic fluoride concentrations were markedly elevated over control levels by exposure to HF. However, in only the kidneys of rats exposed to HF generated by the compressed gas system was there a significant increase in fluoride concentration with increased airborne HF exposure concentration (26 vs. $55 \mathrm{mg} \mathrm{F} / \mathrm{m}^{3}$ ). A concentration of 
MEASURED FLUORIDE CONCENTRATIONS IN SOFT TISSUES OF CHARLES RIVER RATS EXPOSED TO 26,54 or $84 \mathrm{mg} \mathrm{F} / \mathrm{m}^{3}$ HF FOR 6 HOURS 1

Exposure Conditions

(generator system) $\underset{(\mu g / g)}{\text { Lung }}$

Total Ionic
Plasma
$(\mu \mathrm{g} / \mathrm{ml})$
Total Ionic

Kidney

$(\mu \mathrm{g} / \mathrm{g})$

Total Ionic

Postmortem Control2

$0.4 \quad 0.15$

$--\quad--$

0.5

0.25

$26 \mathrm{mg} \mathrm{F} / \mathrm{m}^{3} \mathrm{HF}$

(compressed gas)

$54 \mathrm{mg} \mathrm{F} / \mathrm{m}^{3} \mathrm{HF}$

(compressed gas)

$84 \mathrm{mg} \mathrm{F} / \mathrm{m}^{3} \mathrm{HF}$

(aqueous system)

B Tue Spruce Rats

$27 \mathrm{mg} \mathrm{F} / \mathrm{m}^{3} \mathrm{HF}$

(compressed gas)

$\begin{array}{rr}7.6 & 7.17 \\ .3 & .52\end{array}$

(5)

(5)

$7.9 \quad 8.26$

.7

(5)

.49

(5)

$8.1 \quad 5.44$

$.5 \quad .62$

(5)

(5)

$3.2 \quad 2.98$

$.3 \quad .27$

(5)
(5) $\begin{array}{rr}2.09 & 1.55 \\ .35 & .32\end{array}$

(6) (6)

$2.11 \quad 2.08$

$.35 \quad .32$

(6)

(6)

$5.63 \quad 1.65$

$1.14 \quad .27$

(6)

(6)

$1.24 \quad 1.03$

$.24 \quad .21$

(6)
4.0

.6

(6)

3.42

.54

(6)

1 Values expressed as mean, S.E.M., (number of animals per group).

2 Tissues from control rats were pooled by group ( 6 rats per group) prior to analysis. The values shown are the concentrations measured in the tissue pool of the control group. 
$84 \mathrm{mg} F / \mathrm{m}^{3}$ generated in the aqueous system did not further increase the renal fluoride over that produced by $54 \mathrm{mg} F / \mathrm{m}^{3}$ from the compressed gas system. This is in contrast to Blue Spruce rats in which fluoride concentrations in all tissues analyzed increased with increasing airborne $\mathrm{HF}$ exposure concentration.

Total and ionic fluoride concentration in all three soft tissues analyzed of Char les River rats exposed to $26 \mathrm{mg} F / \mathrm{m}^{3} \mathrm{HF}$ were higher than in Blue Spruce rats exposed to $27 \mathrm{mg} \mathrm{F} / \mathrm{m}^{3}$. However, in plasma and kidney the differences were not statistically significant. The lungs of Charles River rats contained 2.4 times more fluoride (total or ionic) than the lungs of Blue Spruce rats -exposed to similar concentrations of HF. This difference is significant at the $p<0.01$ level. The Charles River rats exposed to $26 \mathrm{mg} \mathrm{F} / \mathrm{m}^{3}$ excreted a mean of $314 \mu \mathrm{g}$ of fluoride (ionic $F^{-}$) during the 6 hour postexposure period compared to $291 \mu \mathrm{g} \mathrm{F}$ in the Blue Spruce rats. The similarity of the urinary fluoride excretion, the plasma fluoride concentrations and kidney fluoride concentrations between Blue Spruce and Charles River rats after exposure to similar $\mathrm{HF}$ concentrations suggests that the systemic fluoride burden in these two groups of rats were similar. The dissimilarity of lung fluoride concentration in exposed Blue Spruce and Charles River rats may be due to differences in the regional deposition of inhaled HF. It is clear, however, that direct comparison of the data from both groups of rats would be inappropriate. 
Qualitative similarities exist between tissue $\Delta F$ levels in Charles River and Blue Spruce rats (Tables 8,16 and 19). In rats obtained from both suppliers exposure to HF generated by the compressed gas system led to low levels of $\Delta F$ while exposure to HF generated by the aqueous system resulted in appreciable levels of $\Delta F$. In lung and kidney of Charles River rats exposed to 26 or $54 \mathrm{mg} \mathrm{F} / 3 \mathrm{HF}$ (compressed gas system) $\Delta F$ concentrations were low and did not increase with increased $\mathrm{HF}$ exposure concentration. In plasma of these rats $\Delta F$ concentration actually decreased significantly with increased HF exposure concentration. The significance of this is unclear.

In Char les River rats exposed to $84 \mathrm{mg} \mathrm{F} / \mathrm{m}^{3} \mathrm{HF}$ generated by the aqueous system the $\Delta F$ concentrations in lung, plasma and kidney averaged $338,71 \%$ and $39 \%$ respectively of the total fluoride concentcations. This response is similar to that of Blue Spruce rats exposed to $55 \mathrm{mg} \mathrm{F} / \mathrm{m}^{3} \mathrm{HF}$ generated by the aqueous system in which these percentages were 56\%, $78 \%$ and 51\%, respectively. In both groups the percentages of $\Delta F$ in lung and kidney were nearly equal and lower than the percentage of $\Delta F$ in the plasma.

The nature of $\Delta F$ in the plasma of Charles River rats following exposure to $84 \mathrm{mg} \mathrm{F} / \mathrm{m}^{3}$ generated by the aqueous system was investigated. Plasma samples were subjected to the calcium phosphate adsorption technique of Venkateswarlu, et al. (1971). This technique is based on the observation that ionic fluoride adsorbs onto crytsalline calcium phosphate and can thus be removed from solution by centrifugation and removal of the crystalline 
TABLE 19

$\triangle F$ CONCENTRATIONS IN SOFT TISSUES OF CHARLES RIVER

RATS EXPOSED TO 26,54 or $84 \mathrm{mg} \mathrm{F} / \mathrm{m}^{3}$ HF FOR 6 HOURS 1

Exposure Conditions
(generator system)

Postmortem control

$26 \mathrm{mg} \mathrm{F} / \mathrm{m}^{3} \mathrm{HF}$

(compressed gas)

$54 \mathrm{mg} \mathrm{F} / \mathrm{m}^{3} \mathrm{HF}$

(compressed gas)

$84 \mathrm{mg} \mathrm{F} / \mathrm{m}^{3} \mathrm{HF}$

(aqueous system)

Blue Spruce Rats

$27 \mathrm{mg} \mathrm{F} / \mathrm{m}^{3} \mathrm{HF}$

(compressed gas)

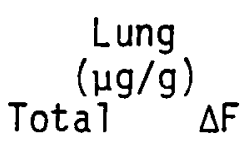

$0.4 \quad 0.2$

$\begin{array}{ll}7.6 & 0.5\end{array}$

$.3 \quad .3$

(5)

(5)

$\begin{array}{ll}7.9 & -0.4\end{array}$

$\begin{array}{ll}.7 & .3\end{array}$

(5) (6)

$8.1 \quad 2.7$

$.5 \quad .3$

(5)

(6)

3.2

(5)
0.2

$(5)$

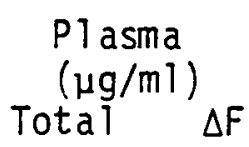

$--\quad \quad--$

$2.09 \quad 0.54$

$.35 \quad .08$

(6) (6)

2.11

.35

(6)

0.03

.08

(6)

5.63

1.14

(6)

3.98

.93

(6)

1.24

.24

(6)
0.21

.05

(6)
Kidney

$(\mu \mathrm{g} / \mathrm{g})$

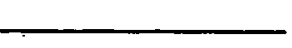

1 Values expressed as mean, S.E.M., (number of animals per group).

2 Tissues from control rats were pooled by group ( 6 rats per group) prior to analysis. The values shown are the concentrations determined on the tissue pool of the control group. 
phosphate. In our laboratory 938 of ionic fluoride standards was recovered in the calcium phosphate layer by this technique. The results of calcium phosphate treatment of plasma are shown in Table 20. Total and ionic fluoride concentrations were determined on both layers; the $\Delta F$ concentration was calculated as the difference between the two. After adsorption the upper layer contained only 48 of the original ionic fluoride present in plasma and $90 \%$ of the recovered $\Delta F$. The crystalline calcium phosphate layer contained 878 of the original ionic $\mathrm{F}^{-}$and 128 of the original $\Delta F$. In the adsorption technique the upper layer was decanted off the crystalline calcium phosphate, leaving behind approximately $10 z$ of the original volume entrapped in the crystalline calcium phosphate layer. This entrapped upper layer may explain the $128 \Delta F$ found in the calcium phosphate layer. The total fluoride recovered calculated by adding the total fluoride content in each layer averaged $107 \%$ of the total fluoride originally present (standard deviation of 10z). This is quite good agreement considering the precision of the ashing method. Venketaswarlu, et al. (1971) term all fluoride which does not adsorb to calcium phosphate non-ionizable fluoride. These results suggest that most if not all of the fluoride in the $\Delta F$ fraction of plasma 6 hours after exposure to $\mathrm{HF}$ generated by the aqueous system is non-ionizable fluoride.

The remaining untreated plasma samples from the animals exposed to $84 \mathrm{mg} \mathrm{F} / \mathrm{m}^{3} \mathrm{~F}$ as $\mathrm{HF}$ were pooled and then subjected to sephadex G-25 gel chromatography. A total of $262.8 \mathrm{ml}$ elution samples were 
TABLE 20

CHARACTERIZATION OF $\triangle F$ IN PLASMA OF CHARLES RIVER RATS EXPOSED TO $84 \mathrm{mg} \mathrm{F} / \mathrm{m}^{3}$ FOR 6 HOURS - CALCIUM PHOSPHATE ADSORPTION 1

\begin{tabular}{|c|c|c|c|c|c|c|c|c|}
\hline & \multicolumn{3}{|c|}{$\begin{array}{c}\text { Fluoride concentration } \\
\text { before adsorption } \\
(\mu \mathrm{g} / \mathrm{m} 1)\end{array}$} & \multicolumn{5}{|c|}{$\begin{array}{c}\text { Fluoride concentration } \\
\text { after ad:orption } \\
(\mu \mathrm{g} / \mathrm{ml})\end{array}$} \\
\hline & & & & & $\begin{array}{l}\text { Non-ioniz } \\
\text { Supernata }\end{array}$ & $F$ & $\begin{array}{l}\text { Ioniz } \\
\text { Cryst } \\
\text { phosp }\end{array}$ & $\begin{array}{l}F^{-} \\
\text {e calcium } \\
\text { pellet }\end{array}$ \\
\hline & Total & Ionic $\mathrm{F}^{-}$ & $\Delta \mathrm{F}$ & $\begin{array}{r}\text { Total F } \\
\text { Recovered }\end{array}$ & Ionic F- & $\Delta F$ & Ionic F & $\Delta \mathrm{F}$ \\
\hline & $\begin{array}{l}6.3 \\
2.3 \\
6.0 \\
3.6 \\
5.0\end{array}$ & $\begin{array}{l}1.0 \\
1.0 \\
2.0 \\
1.4 \\
1.7\end{array}$ & $\begin{array}{l}5.3 \\
1.3 \\
4.0 \\
2.2 \\
3.3\end{array}$ & $\begin{array}{l}6.3 \\
2.3 \\
6.8 \\
3.6 \\
6.1\end{array}$ & $\begin{array}{r}0.03 \\
.04 \\
.12 \\
.03 \\
.06\end{array}$ & $\begin{array}{l}5.0 \\
1.2 \\
4.7 \\
2.1 \\
3.6\end{array}$ & $\begin{array}{l}0.94 \\
0.86 \\
1.67 \\
1.26 \\
1.54\end{array}$ & $\begin{array}{r}0.4 \\
.2 \\
.3 \\
.2 \\
.9\end{array}$ \\
\hline Mean & 4.6 & 1.4 & 3.2 & 5.0 & .06 & 3.3 & 1.25 & .4 \\
\hline
\end{tabular}

1 Individual values are reported. All values reported in a horizontal row were obtained on the plasma of a single rat. HF generated by aqueous system. 
analyzed for total and ionic F. The elution profile is shown in Figure 13. The $2 \mathrm{ml}$ of plasma applied to the column contained 14.2 $\mu g$ total $\mathrm{F}$ and $3.72 \mu \mathrm{g}$ of ionic $\mathrm{F}^{-} ; 928$ of the administered ionic $\mathrm{F}^{-}$was recovered. All the ionic $\mathrm{F}^{-}$was eluted in a single peak with a volume of elution to a void volume ( $\left.\mathrm{V}_{e} / \mathrm{v}_{0}\right)$ ratio of 1.88. One hundred six percent of the total $F$ administered was recovered, however, the large variability in the total fluoride values make it difficult to interpret the elution profile. The variability may in part be due to the large ashing blank which averaged $1.0 \mathrm{\mu g}$ per sample. Two samples had measured total fluoride amounts less than the measured ionic fluoride. If it is assumed that true elution peaks must have width as well as height (i.e., that any peak which does not cover 2 or more elution samples is an analytical artifact) it appears that $\Delta F$ is eluted in two peaks, one with a $\mathrm{v}_{\mathrm{e}} / \mathrm{v}_{\mathrm{o}}$ ratio of 1.62 , the other with a ratio of 1.98. Samples eluting in this portion of the profile have low molecular weights (Thomas, 1977); however, in this range the molecular weight cannot be determined accurately. Since Sephadex G-25 excludes molecules with molecular weights in excess of 5,000 daltons, (these compounds would elute with the void volume, Determan, 1969) and all of the total fluoride was recovered in elution samples with $\mathrm{V}_{\mathrm{e}} / \mathrm{V}_{\mathrm{o}}$ ratios greater than 1.0 the results of this chromatographic procedure suggest that the molecular weight of $\Delta F$ is less than 5,000 daltons.

In the next experiment male Long Evans rats were exposed to $\mathrm{HF}$ generated by the compressed gas system in combination with 
FIGURE 13

Sephadex G-25 elution profile of plasma of Charles River rats exposed to $84 \mathrm{mg} \mathrm{F} / \mathrm{m}^{3} \mathrm{HF}$ generated by the aqueous system. Ionic fluoride content (closed circles) and total fluoride content (open circles) of each elution sample was determined. The volume of elution to the void volume ratios (Ve/Vo) for the major peaks are shown. 


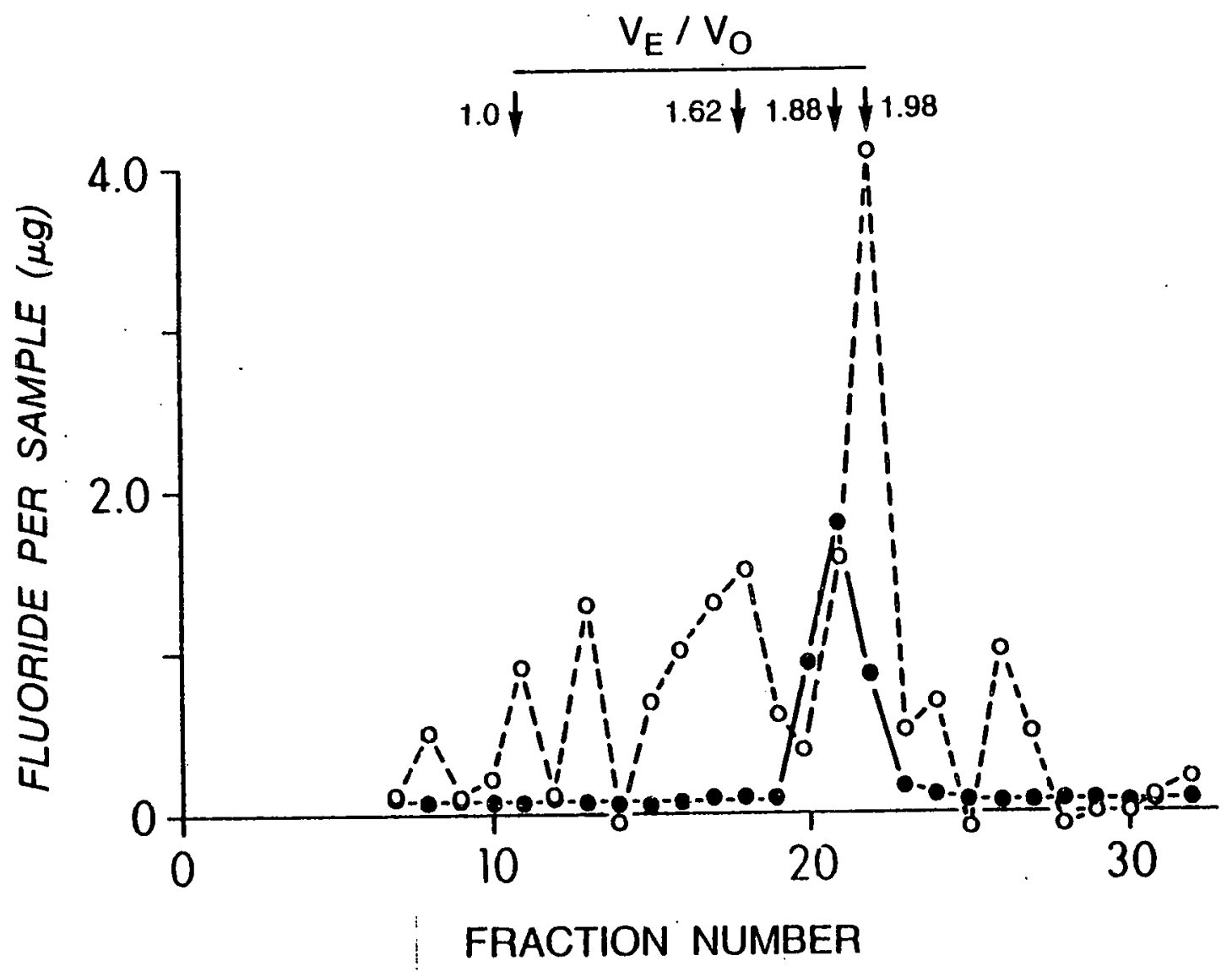


increased relative humidity to investigate if the additional water vapor present in HF atmospheres generated by the aqueous system contributed to the presence of the high $\Delta F$ concentrations in tissues of rats exposed to HF atmosphere generated by the aqueous system. Increased relative humidity was generated by bubbling 4 liters/min of clean room air through double distilled water in a Teflon bubbler and feeding that air into the chamber. Chamber relative humidity was not measured.

In Figure 14 the airborne $F$ concentration measured during the $\mathrm{HF}$ exposure is plotted versus exposure time. The time weighted average fluoride concentration for the 6 hour exposure was $111 \mathrm{mg}$ $\mathrm{F} / \mathrm{m}^{3}$. Also shown in this figure are the airborne fluoride concentrations measured during the $116 \mathrm{mg} \mathrm{F} / \mathrm{m}^{3}$ exposure described in the dose-response experiment. In both cases $1116 \mathrm{mg} \mathrm{F} / \mathrm{m}^{3}$ and $111 \mathrm{mg} \mathrm{F} / \mathrm{m}^{3}$ ) the HF was generated by the compressed gas system; water vapor was added only in the $111 \mathrm{mg} \mathrm{F} / \mathrm{m}^{3}$ exposure. Total flow rates through the chamber were similar in both experiments. The similarity of airborne fluoride concentration during both exposures indicates that any difference in the tissue $F$ levels in animals following these exposure cannot be attributed to differences in the level of $\mathrm{HF}$ present in the chamber air. Animals were sacrificed 6 hours following the termination of both exposures and necropsied in the standard manner. In both cases animals were obtained from Blue Spruce Farms.

The pulmonary and renal effects of exposure to HF plus water vapor are shown in Table 21. The animals exposed to $111 \mathrm{mg} \mathrm{F} / \mathrm{m}^{3}$ 
FIGURE 14

Measured airborne fluoride concentration versus exposure time for

the $111 \mathrm{mg} \mathrm{F} / \mathrm{m}^{3} \mathrm{HF}$ plus water vapor (closed circles) and the

$116 \mathrm{mg} \mathrm{F} / \mathrm{m}^{3}$ (X's) HF exposures. 


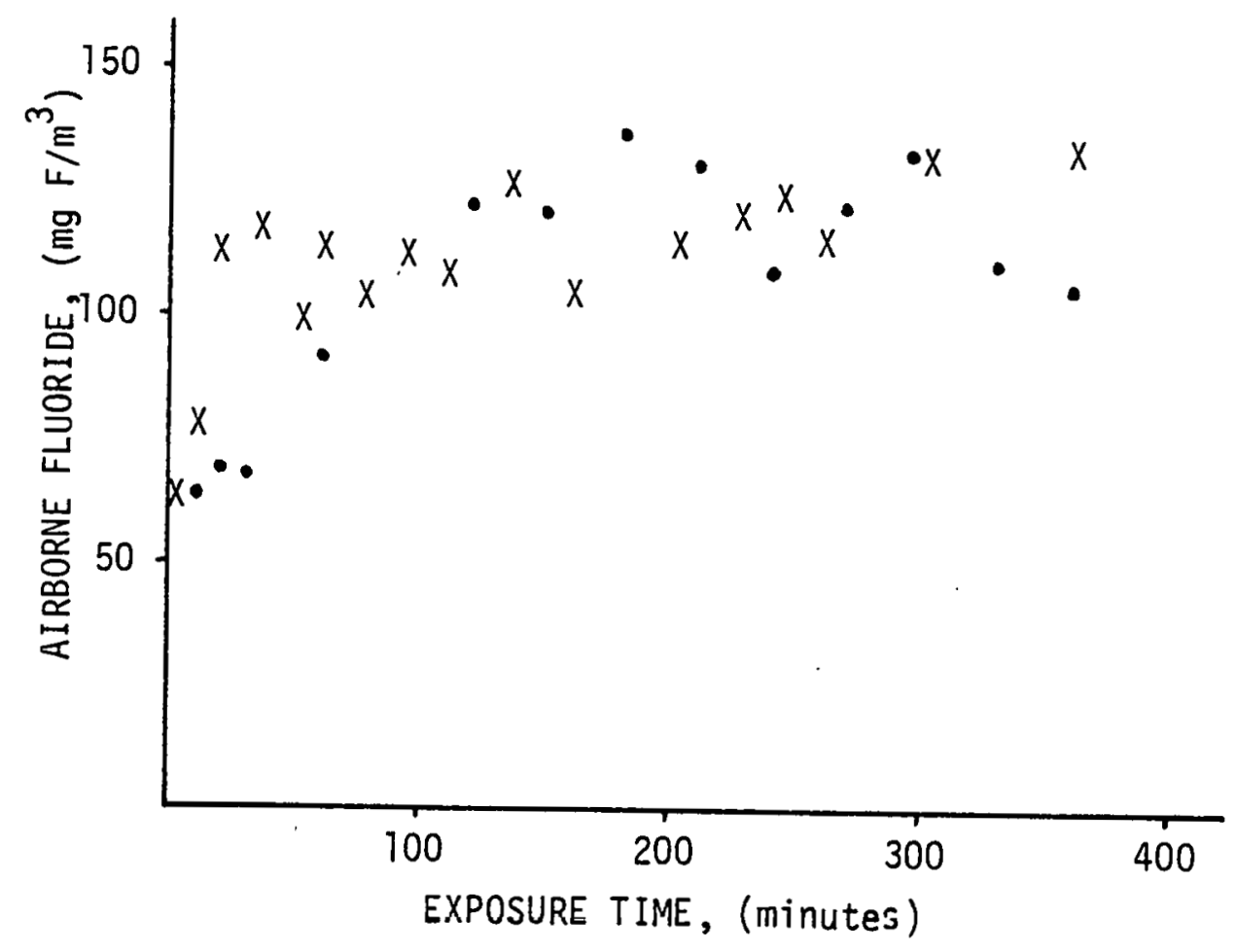


TABLE 21

PULMONARY AND RENAL EFFECTS OF EXPOSURE TO $111 \mathrm{mg} \mathrm{F} / \mathrm{m}^{3}$ PLUS WATER VAPOR 1

\begin{tabular}{|c|c|c|c|c|c|}
\hline Exposure Conditions & $\begin{array}{l}\text { Body Wt. } \\
(y)\end{array}$ & 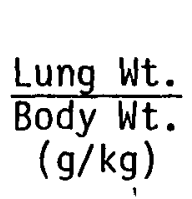 & $\begin{array}{l}\text { Lung } \\
\frac{\text { Wet Wt. }}{\text { Dry Wt. }}\end{array}$ & $\frac{\text { Kidney Wt. }}{\text { Body } W t .}$ & $\begin{array}{l}\text { BUN } \\
\mathrm{mg} \%\end{array}$ \\
\hline $\begin{array}{l}111 \mathrm{mg} \mathrm{F} / \mathrm{m}^{3} \mathrm{HF} \\
\text { plus water vapor }\end{array}$ & $\begin{array}{r}402 \\
3 \\
(6)\end{array}$ & $\begin{array}{l}4.21 \\
.16 \\
(4)^{2}\end{array}$ & $\begin{array}{l}4.72 \\
.02 \\
(3)^{-02}\end{array}$ & $\begin{array}{l}6.34^{b} \\
.19^{9}\end{array}$ & $\begin{array}{l}46.7^{a} \\
3.2^{2} \\
(4)^{2}\end{array}$ \\
\hline $116 \mathrm{mg} \mathrm{F} / \mathrm{m}^{2} \mathrm{HF}$ & $\begin{array}{r}315 \\
6 \\
(6)\end{array}$ & $\begin{array}{l}4.53 \\
.08 \\
(5)^{2}\end{array}$ & $\begin{array}{l}4.89 \\
.13 \\
(5)\end{array}$ & $\begin{array}{l}8.04 \\
.28 \\
(6)\end{array}$ & $\begin{array}{c}62.2 \\
4.3 \\
(6)\end{array}$ \\
\hline Control & $\begin{array}{r}28 j \\
E \\
(1 i)\end{array}$ & $\begin{array}{r}4.41 \\
.10 \\
(10)\end{array}$ & $\begin{array}{r}4.72 \\
.04 \\
(10)\end{array}$ & $\begin{array}{r}7.61 \\
.10 \\
(12)\end{array}$ & $\begin{array}{r}10.1 \\
.5 \\
(12)\end{array}$ \\
\hline
\end{tabular}

1 Values expressed as mean, S.E.M., (number of animals per group). HF generated by compressed gas technique.

a $p>0.05$ compared to $116 \mathrm{mg} \mathrm{F} / \mathrm{m}^{3} \mathrm{HF}$ group.

b $\quad p>0.01$ compared to $116 \mathrm{mg} \mathrm{F} / \mathrm{m}^{3} \mathrm{HF}$ group. 
plus water vapor were older as shown by their body weight, than animals exposed to $116 \mathrm{mg} \mathrm{F} / \mathrm{m}^{3}$ alone. The $\mathrm{kidney}$ weight to body weight ratio was significantly lower in the $111 \mathrm{mg} \mathrm{F} / \mathrm{m}^{3}$ plus water vapor exposed rats than in the other group; however, studies to be described below indicate that the kidney weight to body weight ratio decreases with age. This ratio in the $111 \mathrm{mg} \mathrm{F} / \mathrm{m}^{3}$ plus water vapor group was no different than that in 405 gram control rats sacrificed in the HF retention experiment to be described. The BUN was also significantly lower in rats exposed to HF plus water vapor than in rats exposed to HF alone. However, when BUN is plotted against the logarithm of plasmic ionic fluoride concentration (Figure 9) it is seen that water vapor did not affect the relationship between plasma fluoride and BUN.

Total and ionic fluoride concentrations in soft tissues of rats exposed to $116 \mathrm{mg} \mathrm{F} / \mathrm{m}^{3}$ and $111 \mathrm{mg} \mathrm{F} / \mathrm{m}^{3}$ plus water vapor are given in Table 22. Total and ionic fluoride concentrations in plasma and kidney were unaffected by addition of water vapor to the exposure atmosphere, however both total and ionic lung fluoride concentrationswere significantly lower in rats exposed to $111 \mathrm{mg}$ $\mathrm{F} / \mathrm{m}^{3} \mathrm{HF}$ plus water vapor than rats exposed to $116 \mathrm{mg} \mathrm{F} / \mathrm{m}^{3} \mathrm{HF}$. The similarity in plasma fluoride concentration in these two groups suggests that the systemic fluoride burden in both groups of rats are similar. One possible explanation for these results, therefore, is that increased chamber relative humidity alters the regional deposition of $\mathrm{HF}$ in the respiratory tract without changing the total amount of HF deposited. 
TABLE 22

MEASURED FLUORIDE CONCENTRATIONS IN SOFT TISSUES OF RATS EXPOSED TO $111 \mathrm{mg} \mathrm{F} / \mathrm{m}^{3}$ PLUS WATER VAPOR 1

Exposure
Conditions

$111 \mathrm{mg} \mathrm{F} / \mathrm{m}^{3} \mathrm{HF}$

plus water vapor

12. 2

1.2

(4)

Lung

Total ( $\mu \mathrm{g} / \mathrm{g})$ Ionic

$12.1 \mathrm{a}$

1.4

(4)

19.2

(5)

18.3

$(5)$

0.1
.5
5.40

(4)

(4)

5.70

6.21

.37

(6)

5.73

(6)

0.04

.12
Kidney

$(\mu \mathrm{g} / \mathrm{g})$ Total Ionic

12. $\quad 11.6$

$1.5 \quad 2.3$

(.4) (4)

14. 10.4

$1.3 \quad .9$

(6)

(6)

$\begin{array}{rr}0.3 & 0.08 \\ .5 & .03\end{array}$

1 Values expressed as mean, S.E.M., (number of animals per group). HF generated by compressed gas technique.

2 Tissue samples from control rats were pooled by group ( 6 rats per group) prior to analysis. The values shown are the concentrations measured in the tissue pools of the two control groups sacrificed.

a. $\mathrm{p}<0.05$ compared to $116 \mathrm{mg} \mathrm{F} / \mathrm{m}^{3} \mathrm{HF}$ group. 
Significant amounts of $\Delta F$ were not detected in soft tissues of rats exposed to $111 \mathrm{mg} \mathrm{F} / \mathrm{m}^{3} \mathrm{HF}$ plus water vapor (Table 23). In lung and plasma the total fluoride averaged less than the ionic fluoride concentration, but in both cases the difference was within the precision of the analytical techniques. The $\Delta \mathrm{F}$ concentration in plasma of rats exposed to $111 \mathrm{mg} \mathrm{F} / \mathrm{m}^{3} \mathrm{HF}$ plus water vapor were significantly less than in rats exposed to $116 \mathrm{mg} \mathrm{F} / \mathrm{m}^{3}$ alone. Instead of increasing the amount of $\Delta \mathrm{F}$ present in rats exposed to $\mathrm{HF}$, the addition of water vapor to HF atmospheres appears to actually inhibit the formation of $\Delta \mathrm{F}$.

C. HF Retention Experiment

Sixty male Long Evans rats obtained from Blue Spruce Farms were exposed to HF generated by the compressed gas system for 6 hours in a $1.8 \mathrm{~m}^{3}$ Rochester chamber and sacrificed serially up to 42 days postexposure. Groups of rats were housed in metabolic cages during the postexposure period and 24 hour urine and fecal samples were collected. The purpose of this experiment was to examine the retention and excretion of fluoride in HF exposed rats. Another group of 60 male Long Evans rat were exposed to clean air for 6 hours in a similar chamber three days later and served as a control group. Rats were assigned to control or exposure groups and to specific sacrifice times on the basis of a random number table.

The airborne fluoride concentrations measured at several times during the HF exposure are given in Figure 15. The time weighted average fluoride concentration for the exposure was $10.2 \mathrm{mg} \mathrm{F} / \mathrm{m}^{3}$. 
TABLE 23

$\triangle F$ CONCENTRATIONS IN SOFT TISSUES OF

RATS EXPOSED TO $111 \mathrm{mg} \mathrm{F} / \mathrm{m}^{3}$ PLUS WATER VAPOR 1

Exposure Conditions

Lung
$(\mu g / g)$
Total $_{\Delta F}$

Plasma
$(\mu \mathrm{g} / \mathrm{m} 1)$
$\operatorname{Tota} \Delta \mathrm{F}$

Kidney

$\operatorname{Total}^{(\mu g / g)} \Delta F$

$111 \mathrm{mg} \mathrm{F} / \mathrm{m}^{3} \mathrm{HF}$

plus water vapor

12. $-0.3 \mathrm{a}$

1.2

(4)

$5.40-0.30^{b}$

12.

2. 0.5

(4)

(4) 30

.34

$1.5 \quad 1.1$

$116 \mathrm{mg} \mathrm{F} / \mathrm{m}^{3} \mathrm{HF}$

19. 0.6

2.2

(5)

6.21

.37

(6)

0.48

.16

(6)

(4)

Control2

$$
\begin{array}{rr}
0.1 & 0.1 \\
.5 & .5
\end{array}
$$

$0.04 \quad 0.01$

.09

14. 3.3

$\begin{array}{ll}1.3 & .7\end{array}$

(6)

$$
\begin{array}{rr}
0.3 & 0.2 \\
.5 & .5
\end{array}
$$

1 Values expressed as mean, S.E.M., (number of animals per group). HF generated by compressed gas technique.

2 Tissue samples from control rats were pooled by group (6 rats per group) prior to analysis. The values shown are the concentrations measured in the tissue' pools of the two control groups sacrificed.

a $p<0.05$ compared to $116 \mathrm{mg} \mathrm{F} / \mathrm{m}^{3} \mathrm{HF}$ group.

b $\quad p<0.01$ compared to $116 \mathrm{mg} \mathrm{F} / \mathrm{m}^{3} \mathrm{HF}$ group. 


\section{FIGURE 15}

Measured airborne fluoride concentration versus exposure time in the $10.2 \mathrm{mg} \mathrm{F} / \mathrm{m}^{3} \mathrm{HF}$ retention experiment exposure. 


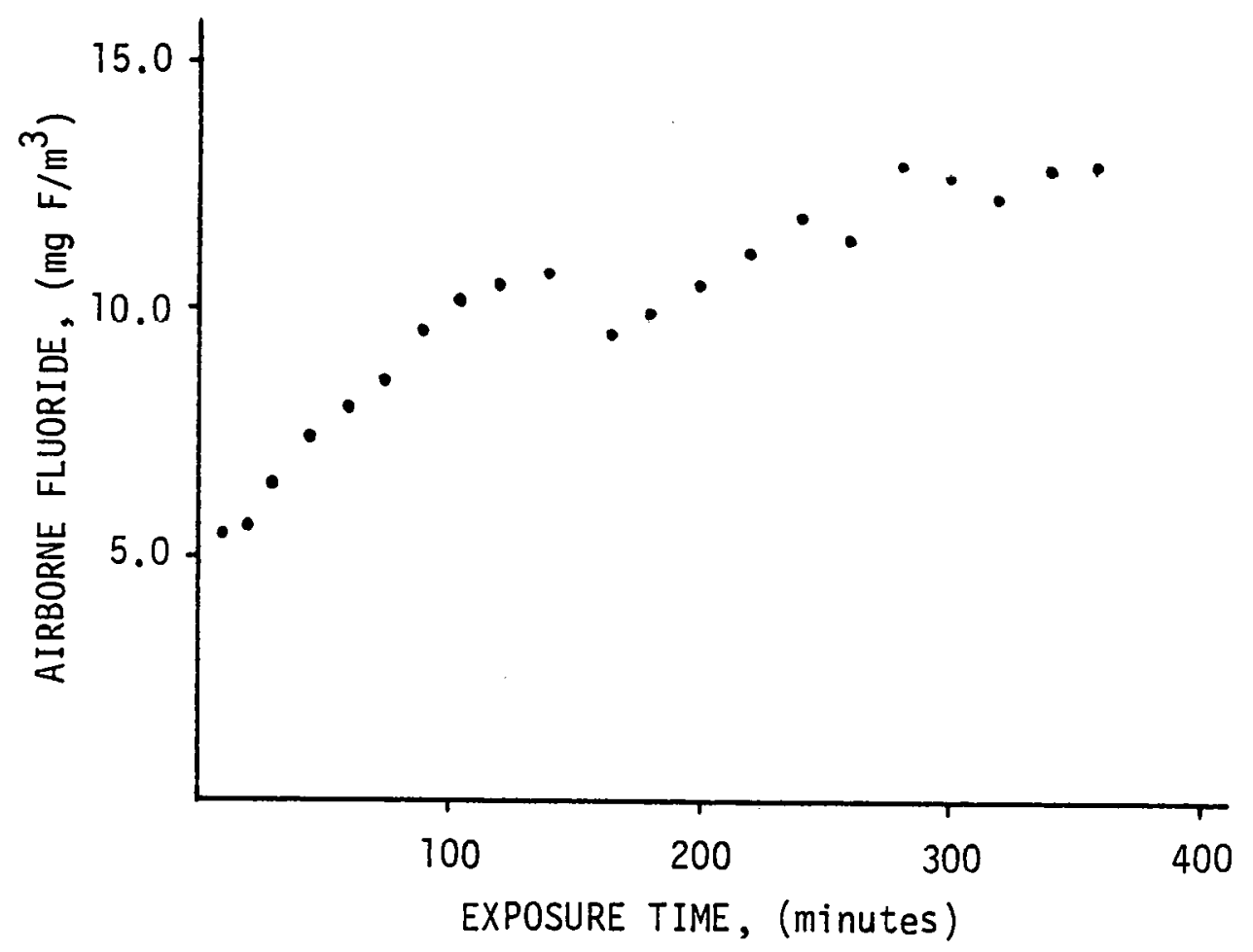


In the subsequent discussion all postexposure times refer to the start of exposure and are given in days. Thus $1 / 4$ day $(6$ hours) represent the animals sacrificed immediately after the 6 hour exposure. Similarly the animals sacrificed at $1 / 2$ day were sacrificed 6 hours after the termination of the 6 hour exposure. These animals are comparable to those in the dose-response experiment. Timing for the control animals refers to the start of the control exposure. Since the HF exposure and the control exposure were separated by 3 days similar times given for the two groups of animals (i.e., 4 days postexposure for exposed versus 4 days postexposure for controls) do not represent the same calendar day.

The pulmonary effects of exposure to $10.2 \mathrm{mg} \mathrm{F} / \mathrm{m}^{3} \mathrm{HF}$ are given in Table 24. All rats were weighed 1 day prior to the HF exposure and 7 days after the HF exposure. At both times the mean body weight of control and exposed rat groups were similar. The body weights at each sacrifice time were similar in control and exposed animals also. The lung weight to body weight ratio in rats sacrificed on day 14 after HF exposure was significantly higher than in control rats sacrificed 14 days after the control exposure. However, at no other time was the lung weight to body weight ratio in HF exposed animals significantly altered and in control rats sacrificed on days $1 / 2,8$ and 28 the mean lung weight to body weight was higher than that in exposed rats sacrificed on day 14 . In no sacrifice group was the lung wet weight to dry weight ratio of exposed rats significantly different than control levels. 
TABLE 24

PULMONARY EFFECTS FOLLOWING EXPOSURE TO $10.2 \mathrm{mg} \mathrm{F} / \mathrm{m}^{3}$

HF FOR 6 HOURS 1

\begin{tabular}{|c|c|c|c|c|c|c|}
\hline \multirow[t]{2}{*}{ Sacrifice day } & \multirow{2}{*}{\multicolumn{2}{|c|}{$\begin{array}{c}\text { Body Weight } \\
\text { Control }(\mathrm{g}) \\
\text { Exposed }\end{array}$}} & \multirow{2}{*}{\multicolumn{2}{|c|}{$\begin{array}{l}\text { Lung Wt. } \\
\text { Body Wt. } \\
\text { (g/kg) } \\
\text { Control Exposed }\end{array}$}} & \multicolumn{2}{|c|}{$\begin{array}{l}\text { Lung } \\
\text { Wet Wt. } \\
\text { Dry Wt. }\end{array}$} \\
\hline & & & & & Control & Exposed \\
\hline$-1 \quad(-4)^{2}$ & $\begin{array}{c}305 \\
2 \\
(60)\end{array}$ & $\begin{array}{c}303 \\
2 \\
(60)\end{array}$ & & & & \\
\hline$\frac{1}{4}$ & $\begin{array}{r}338 \\
9 \\
(6)\end{array}$ & $\begin{array}{r}311 \\
10 \\
(6)\end{array}$ & $\begin{array}{l}4.24 \\
(5)^{13}\end{array}$ & $\begin{array}{l}4.57 \\
(5)^{20}\end{array}$ & $\begin{array}{l}4.71 \\
(.03\end{array}$ & $\begin{array}{l}4.78 \\
(502\end{array}$ \\
\hline$\frac{1}{2}$ & $\begin{array}{r}321 \\
7 \\
(6)\end{array}$ & $\begin{array}{r}290 \\
3 \\
(6)\end{array}$ & $\begin{array}{l}4.94 \\
.75 \\
150\end{array}$ & $\begin{array}{l}4.42 \\
(5)^{20}\end{array}$ & $\begin{array}{l}4.60 \\
(\dot{5})^{4}\end{array}$ & $\begin{array}{l}4.73 \\
.03 \\
(5)\end{array}$ \\
\hline 1 & $\begin{array}{r}306 \\
7 \\
(6)\end{array}$ & $\begin{array}{r}293 \\
3 \\
(6)\end{array}$ & $\begin{array}{l}4.26 \\
(5)^{20}\end{array}$ & $\begin{array}{l}4.28 \\
(5)\end{array}$ & $\begin{array}{l}4.70 \\
(\dot{5})^{-05}\end{array}$ & $\begin{array}{l}4.74 \\
(5)^{.04}\end{array}$ \\
\hline 2 & $\begin{array}{r}333 \\
7 \\
(6)\end{array}$ & $\begin{array}{r}317 \\
7 \\
(6)\end{array}$ & $\begin{array}{l}4.17 \\
.19 \\
(5)\end{array}$ & $\begin{array}{l}4.11 \\
.07 \\
(5)\end{array}$ & $\begin{array}{l}4.71 \\
(5)^{.04}\end{array}$ & $\begin{array}{l}4.76 \\
.05 \\
(5)\end{array}$ \\
\hline 4 & $\begin{array}{r}337 \\
12 \\
(6)\end{array}$ & $\begin{array}{r}335 \\
6 \\
(6)\end{array}$ & $\begin{array}{l}4.24 \\
(51 \\
(5)\end{array}$ & $\begin{array}{l}4.17 \\
(5)\end{array}$ & $\begin{array}{l}4.92 \\
\left(\dot{5}^{14}\right.\end{array}$ & $\begin{array}{l}4.67 \\
(5)^{.05}\end{array}$ \\
\hline $7 \quad(3)^{2}$ & $\begin{array}{c}341 \\
4 \\
(30)\end{array}$ & $\begin{array}{c}340 \\
5 \\
(24)\end{array}$ & & & & \\
\hline 8 & $\begin{array}{r}343 \\
12 \\
(5)\end{array}$ & $\begin{array}{r}306 \\
12 \\
(6)\end{array}$ & $\begin{array}{l}4.51 \\
(\dot{5})^{28}\end{array}$ & $\begin{array}{l}4.22 \\
(5)^{10}\end{array}$ & $\begin{array}{l}4.72 \\
(5)^{.04}\end{array}$ & $\begin{array}{l}4.72 \\
(.04\end{array}$ \\
\hline 14 & $\begin{array}{r}353 \\
7 \\
(6)\end{array}$ & $\begin{array}{r}329 \\
11 \\
(6)\end{array}$ & $\begin{array}{l}4.03 \\
(5)^{14}\end{array}$ & $\begin{array}{l}4.50^{a} \\
(5)^{10}\end{array}$ & $\begin{array}{l}4.82 \\
(4)^{08}\end{array}$ & $\begin{array}{l}4.71 \\
(.05\end{array}$ \\
\hline 21 & & $\begin{array}{r}390 \\
11 \\
(6)\end{array}$ & & $\begin{array}{l}4.34 \\
.16 \\
(5)\end{array}$ & & $\begin{array}{l}4.84 \\
(\dot{5})\end{array}$ \\
\hline
\end{tabular}


TABLE 24 (continued)

\section{PULMONARY EFFECTS FOLLOWING EXPOSURE TO $10.2 \mathrm{mg} \mathrm{F} / \mathrm{m}^{3}$} HF FOR 6 HOURS 1

\begin{tabular}{|c|c|c|c|c|c|c|}
\hline \multirow[t]{2}{*}{ Sacrifice day } & \multicolumn{2}{|c|}{$\begin{array}{l}\text { Body Weight } \\
(\mathrm{g})\end{array}$} & \multirow{2}{*}{\multicolumn{2}{|c|}{$\begin{array}{l}\frac{\text { Lung Wt. }}{\text { Body Wt. }} \\
\text { (g/kg) } \\
\text { Control Exposed }\end{array}$}} & \multicolumn{2}{|c|}{$\begin{array}{l}\text { Lung } \\
\frac{\text { Wet Wt. }}{\text { Dry Wt. }}\end{array}$} \\
\hline & Control & Exposed & & & Control & Exposed \\
\hline 28 & $\begin{array}{r}405 \\
12 \\
(6)\end{array}$ & $\begin{array}{r}381 \\
16 \\
(6)\end{array}$ & $\begin{array}{l}4.84 \\
.41 \\
(5)\end{array}$ & $\begin{array}{l}3.87 \\
.16 \\
(5)\end{array}$ & $\begin{array}{l}4.68 \\
.03 \\
(5)^{2}\end{array}$ & $\begin{array}{l}4.73 \\
.02 \\
(5)\end{array}$ \\
\hline 42 & $\begin{array}{r}467 \\
11 \\
(6)\end{array}$ & $\begin{array}{r}467 \\
15 \\
(6)\end{array}$ & $\begin{array}{l}3.53 \\
.07 \\
(5)\end{array}$ & $\begin{array}{l}3.67 \\
.13 \\
(5)\end{array}$ & $\begin{array}{l}4.69 \\
.06 \\
(5)^{-0}\end{array}$ & $\begin{array}{l}4.60 \\
.01 \\
(5)\end{array}$ \\
\hline
\end{tabular}

1 Values expressed as mean, S.E.M., (number of animals per group). HF generated by compressed gas technique.

2 Sacrifice day is reported with respect to the day of control or HF exposure. On days -1 and 7 with respect to the HF exposure all rats were weighed. These two days correspond to days -4 and 3 , respectively, with respect to the control exposure. 
The renal effects of exposure to $10.2 \mathrm{mg} \mathrm{F} / \mathrm{m}^{3} \mathrm{HF}$ are given in Table 25. It was noticed during the first few days postexposure that urines collected from nonfasting rats were heavily contaminated with food and/or feces. It was decided, therefore, to fast the animals for the 24 hour period prior to sacrifice. Therefore, the animals were fasted on days $8,14,21,28$ and 42 . The experimental protocol already called for fasting on day 1. The urine samples collected for fasting animals were much cleaner than those for animals which had access to food. Tap water was always available. The kidney weight to body weight ratio in exposed animals sacrificed on day 8 was significantly higher than day 8 control levels. However, at no other time was this ratio elevated in exposed animals. In both control and exposed rats the kidney weight to body weight ratio decreased significantly on the 42 nd day postexposure period. The BUN was not elevated in exposed rats sacrificed from days $1 / 2$ to 14 . BuN was not measured on rats sacrificed on days 21,28 or 42 because no effect was seen during the first 14 days after exposure. Also, no effect of HF exposure on urinary protein excretion was evident. Urinary protein was only measured on days $1,2,4$ and 8 . The urinary protein excretion was significantly lower during days in which the rats were fasting. This may represent decreased food and/or fecal contamination of urine on those days or may be due to some physiological response of the rat to food deprivation. Water consumption and urine volume were measured throughout the entire 42 day postexposure pcriod. HF cxposure did not effect any of these parameters. 
RENAL EFFECTS FOLLOWING EXPOSURE TO $10.2 \mathrm{mg} \mathrm{F} / \mathrm{m}^{3} \mathrm{HF} 1$

\begin{tabular}{|c|c|c|c|c|c|c|}
\hline \multirow{2}{*}{$\begin{array}{l}\text { Sacrifice day } \\
\qquad \frac{1}{4}\end{array}$} & \multicolumn{2}{|c|}{$\begin{array}{c}\frac{\text { Kidney Wt. }}{\text { Body Wt. }} \\
\text { Control } \mathrm{g} / \mathrm{kg}) \\
\text { Cxposed }\end{array}$} & \multirow[t]{2}{*}{$\begin{array}{r}\text { BUN } \\
(\mathrm{mg} \%) \\
\text { Control }\end{array}$} & \multirow[t]{2}{*}{ Exposed } & \multicolumn{2}{|c|}{$\begin{array}{l}\text { Urinary Protein Exc. } \\
\text { (mg/day) } \\
\text { Control Exposed }\end{array}$} \\
\hline & $\begin{array}{r}7.12 \\
.15 \\
(6)\end{array}$ & $\begin{array}{r}7.47 \\
.14 \\
(6)\end{array}$ & & & & \\
\hline$\frac{1}{2}$ & $\begin{array}{r}7.06 \\
.24 \\
(6)\end{array}$ & $\begin{array}{r}7.15 \\
.05 \\
(6)\end{array}$ & $\begin{array}{c}10.1^{2} \\
.5 \\
(12)\end{array}$ & $\begin{array}{l}9.5 \\
(\dot{6})\end{array}$ & & \\
\hline 13 & $\begin{array}{r}7.33 \\
.13 \\
(6)\end{array}$ & $\begin{array}{r}7.01 \\
.17 \\
(6)\end{array}$ & $\begin{array}{l}9.1 \\
(\dot{6})\end{array}$ & $\begin{array}{r}10.3 \\
(6)\end{array}$ & $\begin{array}{c}64 \\
8 \\
(6)\end{array}$ & $\begin{array}{c}72 \\
5 \\
(6)\end{array}$ \\
\hline 2 & $\begin{array}{r}7.09 \\
.14 \\
(6)\end{array}$ & $\begin{array}{r}7.37 \\
.25 \\
(6)\end{array}$ & $\begin{array}{r}14.2 \\
(\dot{6})\end{array}$ & $\begin{array}{r}13.9 \\
(6)\end{array}$ & $\begin{array}{r}120 \\
11 \\
(6)\end{array}$ & $\begin{array}{r}116 \\
6 \\
(6)\end{array}$ \\
\hline 4 & $\begin{array}{r}7.02 \\
.26 \\
(6)\end{array}$ & $\begin{array}{r}6.89 \\
.12 \\
(6)\end{array}$ & $\begin{array}{r}13.8 \\
.5 \\
(6)\end{array}$ & $\begin{array}{r}14.4 \\
1.1 \\
(6)\end{array}$ & $\begin{array}{r}116 \\
6 \\
(6)\end{array}$ & $\begin{array}{r}121 \\
3 \\
(6)\end{array}$ \\
\hline 84 & $\begin{array}{r}6.72 \\
.20 \\
(5)\end{array}$ & $\begin{array}{l}7.38^{\mathrm{a}} \\
.14 \\
(6)\end{array}$ & $\begin{array}{l}13.5 \\
(6)^{9}\end{array}$ & $\begin{array}{r}12.5 \\
1.4 \\
(6)\end{array}$ & $\begin{array}{r}97 \\
5 \\
(6)\end{array}$ & $\begin{array}{r}86 \\
2 \\
(6)^{2}\end{array}$ \\
\hline 144 & $\begin{array}{r}6.74 \\
.15 \\
(6)\end{array}$ & $\begin{array}{r}7.11 \\
.30 \\
(5)\end{array}$ & $\begin{array}{r}14.7 \\
.8 \\
(6)\end{array}$ & $\begin{array}{r}13.0 \\
\dot{(6)}\end{array}$ & & \\
\hline 214 & & $\begin{array}{r}6.44 \\
i 16 \\
(6)\end{array}$ & & & & \\
\hline 284 & $\begin{array}{r}6.33 \\
.19 \\
(6)\end{array}$ & $\begin{array}{r}6.60 \\
19 \\
(6)\end{array}$ & & & & \\
\hline
\end{tabular}


TABLE 25 (continued)

RENAL EFFECTS FOLLOWING EXPOSURE TO $10.2 \mathrm{mg} \mathrm{F} / \mathrm{m}^{3} \mathrm{HF}^{1}$

\begin{tabular}{|c|c|c|c|c|}
\hline Sacrifice day & $\begin{array}{r}\frac{K}{B C} \\
\text { Contro }\end{array}$ & $\begin{array}{l}\frac{\text { ney } W t .}{y W t .} \\
(\mathrm{kg}) \\
\text { Exposed }\end{array}$ & $\begin{array}{l}\text { BUN } \\
\text { (mg\%) } \\
\text { Control Exposed }\end{array}$ & $\begin{array}{c}\text { Urinary Protein Exc. } \\
\text { (mg/day) } \\
\text { Control Exposed }\end{array}$ \\
\hline 424 & $\begin{array}{r}6.44 \\
.20 \\
(6)\end{array}$ & $\begin{array}{r}6.20 \\
.15 \\
(6)\end{array}$ & & \\
\hline
\end{tabular}

1 Values reported as mean, S.E.M., (number of animals per group). HF generated by compressed gas technique.

2 These values are from control rats sacrificed in dose response experiment

3 Urine collected from $6-24$ hours on 1st day (18 hour urine). Rats were fasted during this period.

4 Rats were fasted during this 24 hour period. 
Total and ionic fluoride concentrations in soft tissues of control animals are shown in Table 26. The lungs from each animal in a sacrifice group were pooled and then homogenized as were also the kidneys. The plasmas were analyzed for ionic fluoride separately and then pooled for ashing. The mean ionic plasma fluoride concentration is given, the standard error for each group was less than $0.005 \mu \mathrm{g} / \mathrm{ml}$. The ionic fluoride in lungs of control animals sacrificed at $1 / 4$ day was higher than at any other time. The reasons for this are not clear, but a similar effect has been seen previously in control chamber exposed guinea pigs (Smith, 1975). The data from every sacrific time were used to calculate the mean and standard error for the entire control group. These values are given at the bottom of the table.

Total, and ionic concentrations in soft tissues of animals sacrificed after exposure to $\mathrm{HF}$ are given in Table 27 . The fluoride concentrations in all soft tissues of rats sacrificed at $1 / 2$ day in this experiment are quite similar to those in rats sacrificed 6 hours after 6 hour exposure to $11 \mathrm{mg} F / \mathrm{m}^{3}$ in the dose-response experiment (Table 15). Total and ionic fluoride levels in all three tissues were significantly elevated immediately following exposure ( $1 / 4$ day group). Ionic fluoride concentrations in these rats was elevated by at least an order of magnitude over control levels. These animals ( $1 / 4$ day group) were sacrificed from 5 to 65 minutes following exposure to $\mathrm{HF}$. Ionic lung fluoride concentration did not consistently decrease with succeeding $r$ ats sacrificed within this time period, suggesting that large amounts 
TABLE 26

MEASURED FLUORIDE CONCENTRATIONS IN SOFT TISSUES OF RATS SACRIFICED SERIALLY AFTER CONTROL EXPOSURE 1

\begin{tabular}{ccccccc} 
Sacrifice Day & \multicolumn{2}{c}{$\begin{array}{c}\text { Lung } \\
(\mu \mathrm{g} / \mathrm{g})\end{array}$} & \multicolumn{2}{c}{$\begin{array}{c}\text { Plasma } \\
(\mu \mathrm{g} / \mathrm{ml})\end{array}$} & \multicolumn{2}{c}{$\begin{array}{c}\text { Kidney } \\
\text { ( } \mu \mathrm{g} / \mathrm{g})\end{array}$} \\
& \multicolumn{1}{c}{ Total } & Ionic & Total & Ionic & Total & Ionic \\
$\frac{1}{4}$ & 0.4 & 0.17 & 0.12 & 0.048 & 0.1 & 0.10 \\
1 & 0.5 & .05 & .08 & .029 & 0.2 & .02 \\
2 & 0.2 & .02 & .09 & .035 & 0.2 & .04 \\
4 & 0.6 & .02 & .05 & .043 & 0.2 & .04 \\
8 & 0.4 & .03 & .12 & .037 & 0.1 & .03 \\
14 & 0.5 & .02 & .10 & .036 & 0.1 & .02 \\
28 & 0.8 & .04 & .06 & .040 & 0.1 & .03 \\
42 & 0.2 & .02 & .06 & .036 & 0.3 & .02 \\
Mean & 0.7 & .00 & .08 & .035 & 0.0 & .04 \\
S.E.M. & 0.5 & .04 & .08 & .038 & 0.1 & .04 \\
(n) & 0.1 & .02 & .01 & .002 & .0 & .01 \\
& $(9)$ & $(9)$ & $(9)$ & $(9)$ & $(9)$ & $(9)$
\end{tabular}

1 Tissue samples from control rats were pooled by group (5-6 rats per group) prior to analysis. The values shown are the concentrations measured in the tissue pool of each group. HF generated by compressed gas technique. 


\section{TABLE 27}

MEASURED FLUORIDE CONCENTRATIONS IN RATS SACRIFICED

SERIALLY AFTER EXPOSURE TO $10.2 \mathrm{mg} \mathrm{F} / \mathrm{m}^{3} \mathrm{HF}$ FOR 6 HOURS 1

\begin{tabular}{|c|c|c|c|c|c|c|}
\hline \multirow{2}{*}{$\begin{array}{l}\text { Sacrifice Day } \\
\qquad \frac{1}{4}\end{array}$} & \multicolumn{2}{|c|}{$\begin{array}{c}\text { Lung } \\
(\mu g / g) \\
\text { Total Ionic }\end{array}$} & \multicolumn{2}{|c|}{$\begin{array}{c}\text { Plasma } \\
(\mu \mathrm{g} / \mathrm{ml}) \\
\text { Total Ionic }\end{array}$} & \multicolumn{2}{|c|}{$\begin{array}{c}\text { Kidney } \\
(\mu g / g) \\
\text { Total Ionic }\end{array}$} \\
\hline & $\begin{array}{l}3.7 \\
0.6 \\
(5)\end{array}$ & $\begin{array}{r}3.27 \\
.36 \\
(5)\end{array}$ & $\begin{array}{r}0.63 \\
.12 \\
(5)\end{array}$ & $\begin{array}{r}0.53 \\
.13 \\
(5)\end{array}$ & $\begin{array}{l}2.1 \\
0.3 \\
(5)\end{array}$ & $\begin{array}{r}1.51 \\
.21 \\
(5)\end{array}$ \\
\hline$\frac{1}{2}$ & $\begin{array}{l}1.5 \\
.2 \\
(5)\end{array}$ & $\begin{array}{r}1.28 \\
.26 \\
(6)\end{array}$ & $\begin{array}{r}0.52 \\
.10 \\
(6)\end{array}$ & $\begin{array}{r}0.52 \\
.07 \\
(6)\end{array}$ & $\begin{array}{l}1.7 \\
.2 \\
(6)\end{array}$ & $\begin{array}{r}1.21 \\
.06 \\
(6)\end{array}$ \\
\hline 1 & $\begin{array}{l}1.2 \\
.1 \\
(5)\end{array}$ & $\begin{array}{r}0.58 \\
.12 \\
(5)\end{array}$ & $\begin{array}{l}0.27 \\
.08 \\
(6)\end{array}$ & $\begin{array}{r}0.26 \\
.05 \\
(6)\end{array}$ & $\begin{array}{l}0.8 \\
.1 \\
(6)\end{array}$ & $\begin{array}{r}0.62 \\
.08 \\
(6)\end{array}$ \\
\hline 2 & $\begin{array}{l}1.1 \\
i^{2} \\
5\end{array}$ & $\begin{array}{r}0.42 \\
10 \\
(5)\end{array}$ & $\begin{array}{r}0.11 \\
.01 \\
(6)\end{array}$ & $\begin{array}{c}0.082 \\
.008 \\
(6)\end{array}$ & $\begin{array}{l}0.8 \\
.2 \\
(6)\end{array}$ & $\begin{array}{r}0.25 \\
.02 \\
(6)\end{array}$ \\
\hline 4 & $\begin{array}{l}0.9 \\
i^{2} \\
(5)\end{array}$ & $\begin{array}{r}0.15 \\
.02 \\
(5)\end{array}$ & $\begin{array}{r}0.09 \\
.02 \\
(6)\end{array}$ & $\begin{array}{c}0.058 \\
.002 \\
(6)\end{array}$ & $\begin{array}{l}0.5 \\
.1 \\
(6)\end{array}$ & $\begin{array}{l}0.11 \\
.01 \\
(6)\end{array}$ \\
\hline 8 & $\begin{array}{c}0.9 \\
.3 \\
(5)\end{array}$ & $\begin{array}{r}0.22 \\
.03 \\
(5)\end{array}$ & $\begin{array}{r}0.09 \\
.01 \\
(6)\end{array}$ & $\begin{array}{l}0.073 \\
.003 \\
(6)\end{array}$ & $\begin{array}{l}0.6 \\
.1 \\
(6)\end{array}$ & $\begin{array}{r}0.13 \\
.01 \\
(6)\end{array}$ \\
\hline 14 & $\begin{array}{l}0.5 \\
.0 \\
(5)\end{array}$ & $\begin{array}{r}0.11 \\
.00 \\
(5)\end{array}$ & $\begin{array}{r}0.13 \\
.03 \\
(6)\end{array}$ & $\begin{array}{l}0.052 \\
.002 \\
(6)\end{array}$ & $\begin{array}{l}0.5 \\
.1 \\
(6)\end{array}$ & $\begin{array}{r}0.10 \\
.01 \\
(6)\end{array}$ \\
\hline 21 & $\begin{array}{l}0.7 \\
.2 \\
(5)\end{array}$ & $\begin{array}{r}0.09 \\
.01 \\
(5)\end{array}$ & $\begin{array}{l}0.08 \\
.00 \\
(6)\end{array}$ & $\begin{array}{l}0.050 \\
i 003 \\
(6)\end{array}$ & $\begin{array}{l}0.4 \\
.1 \\
(6)\end{array}$ & $\begin{array}{r}0.10 \\
.01 \\
(6)\end{array}$ \\
\hline 28 & $\begin{array}{l}0.7 \\
.2 \\
(5)\end{array}$ & $\begin{array}{r}0.04 \\
.01 \\
(5)\end{array}$ & $\begin{array}{r}0.09 \\
.03 \\
(6)\end{array}$ & $\begin{array}{l}0.044 \\
.003 \\
(6)\end{array}$ & $\begin{array}{l}0.3 \\
.1 \\
(6)\end{array}$ & $\begin{array}{r}0.06 \\
.00 \\
(6)\end{array}$ \\
\hline 42 & $\begin{array}{r}0.5 \\
.1 \\
(5)\end{array}$ & $\begin{array}{l}0.07 \\
.01 \\
(5)\end{array}$ & $\begin{array}{r}0.00 \\
.01 \\
(6)\end{array}$ & $\begin{array}{l}0.42 \\
.002 \\
(6)\end{array}$ & $\begin{array}{c}0.3 \\
.1 \\
(6)\end{array}$ & $\begin{array}{r}0.09 \\
.02 \\
(6)\end{array}$ \\
\hline
\end{tabular}


TABLE 27 (continued)

MEASURED FLUORIDE CONCENTRATIONS IN RATS SACRIFICED SERIALLY AFTER EXPOSURE TO $10.2 \mathrm{mg} \mathrm{F} / \mathrm{m}^{3} \mathrm{HF}$ FOR 6 HOURS 1

Sacrifice Day

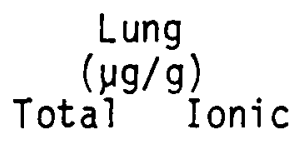

0.5

(9)
0.04

.02

(9)

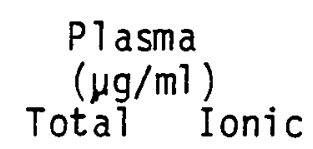

0.08

.01

(9)
0.038

.002

(9)
Kidney

$(\mu \mathrm{g} / \mathrm{g})$

1 Values expressed as mean, S.E.M., (nmber of animals per group). HF generated by the compressed gas technique.

a $\quad p<0.05$ compared to control

b $p<0.01$ compared to control 
of fluoride are not cleared from the lung within 5-65 minute postexposure period. The ionic lung fluoride concentration was significantly higher than control levels in animals sacrificed from $1 / 4$ to 21 days postexposure; the ionic lung fluoride concentration in animals sacrificed on days 28 and 42 was no different from control levels. Similarly the ionic plasma fluoride concentration in exposed animals sacrificed on days $1 / 4$ through 28 were significantly higher than control. In exposed rats the concentration of ionic fluoride in lung was significantly higher than in plasma in every sacrifice group except the 28 day group. The ionic fluoride levels in the kidneys of exposed animals were significantly higher than control levels at every sacrifice time up to and including 42 days postexposure.

The mean lung, plasma and kidney ionic fluoride concentrations are plotted versus postexposure time in Figure 16. A similar plot is obtained with total $F$ concentrations, but since the ionic fluoride analytical technique is more precise and has a limit of sensitivity 10 times lower than the total fluoride method, ionic fluoride levels are used in this figure and in subsequent calculations. In all three tissues most of the fluoride is removed quickly after HF exposure but a small fraction of the fluoride is retained for a long period of time.

The arithmetic mean lung ionic fluoride data were analyzed for decay constants and intercepts by curve fitting. The mean control ionic lung fluoride concentration $(0.04 \mu \mathrm{g} / \mathrm{g})$ was subtracted from the mean ionic lung fluoride concentration of each exposed animal 
FIGURE 16

Mean lung, plasma and kidney ionic fluoride concentration following exposure to $10.2 \mathrm{mg} \mathrm{F} / \mathrm{m}^{3} \mathrm{HF}$ versus postexposure time. The mean control value is shown by the horizontal line. 

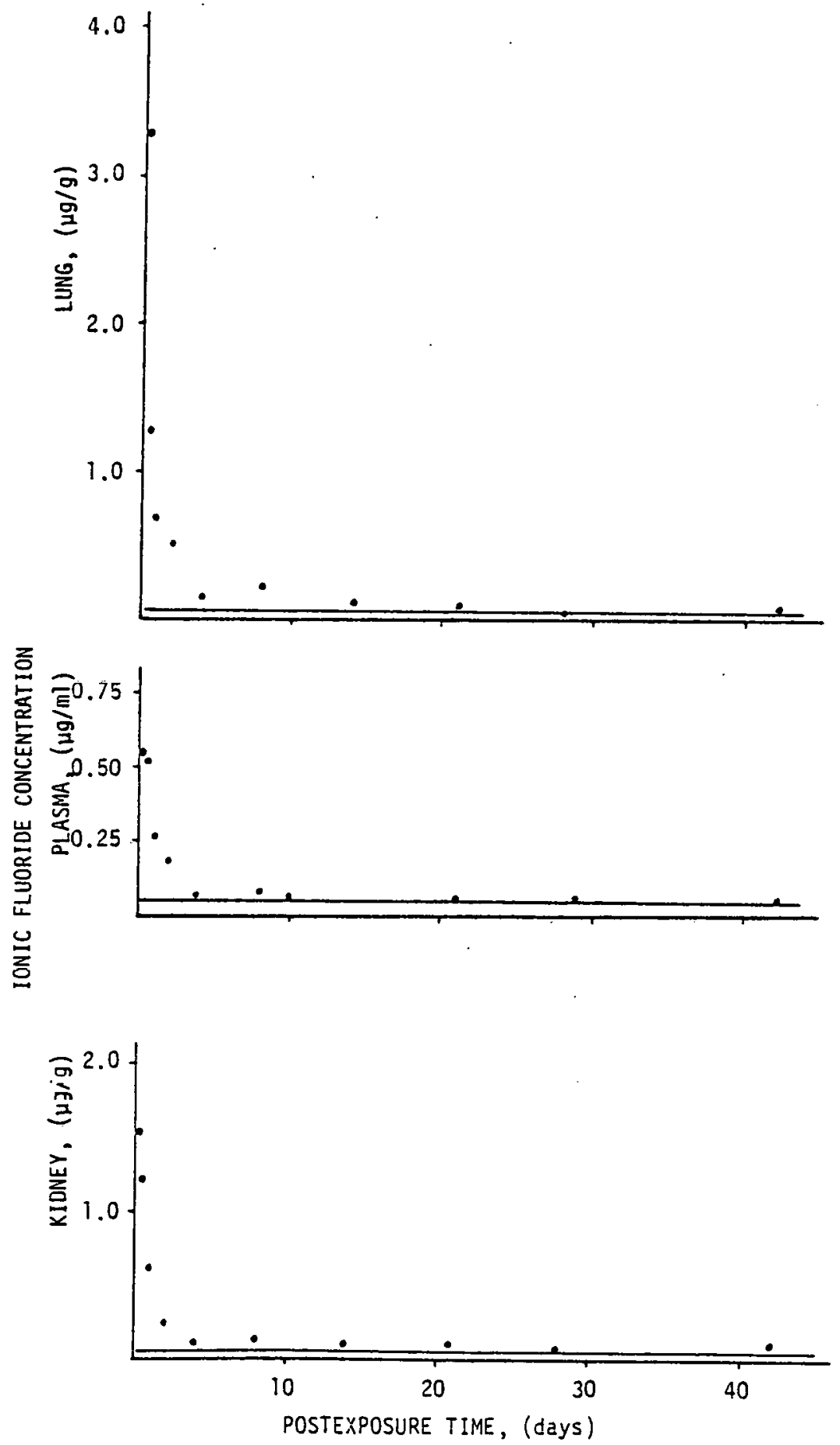
sacrifice group for analysis. These data are plotted semilogarithmically against postexposure time in Figure 17. The data for animals sacrificed on days 28 and 42 were not used because the lung fluoride levels in these animals were not significantly higher than control levels. The lines were fit by a least squares technique linear regression using the logarithm of the ionic fluoride concentration and postexposure time. The large amount of scatter in the data is evident in Figure 17. The pulmonary retention of fluoride following $\mathrm{HF}$ exposure appears to be biphasic. The equation obtained for the ionic lung fluoride concentration (L) after $\mathrm{HF}$ exposure is:

$$
L=2.98(\mu g / g) e^{-3.08 t}+0.29(\mu g / g) \text { e }-0.087 t
$$

with the fractional transfer constants given in day ${ }^{-1}$.

The plasma and kidney data were analyzed by the same technique. The fraction of the initial flouride concentration ( $1 / 4$ day) and the retention half-times calculated for all three soft tissues are given in Table 28. The 958 confidence limits for each calculated half-time are also given in this table. The large scatter in the data is reflected in these $95 \%$ confidence limits.

The concenctration of fluoride in the lung immediately after HF exposure is dependent on the rate at which it enters this site during exposure and the rate with which it is removed. If the expected lung burden at the end of the 6 hour exposure is estimated assuming a ventilation rate of 0.15 liter/minfor the $300 \mathrm{gram}$ rat (Guytun, 1947) and the retention k1netles obtained in this 


\section{FIGURE 17}

Log of the mean lung ionic fluoride concentration following

exposure to $10.2 \mathrm{mg} \mathrm{F} / \mathrm{m}^{3} \mathrm{HF}$ versus postexposure time. The linear regression lines are shown. 


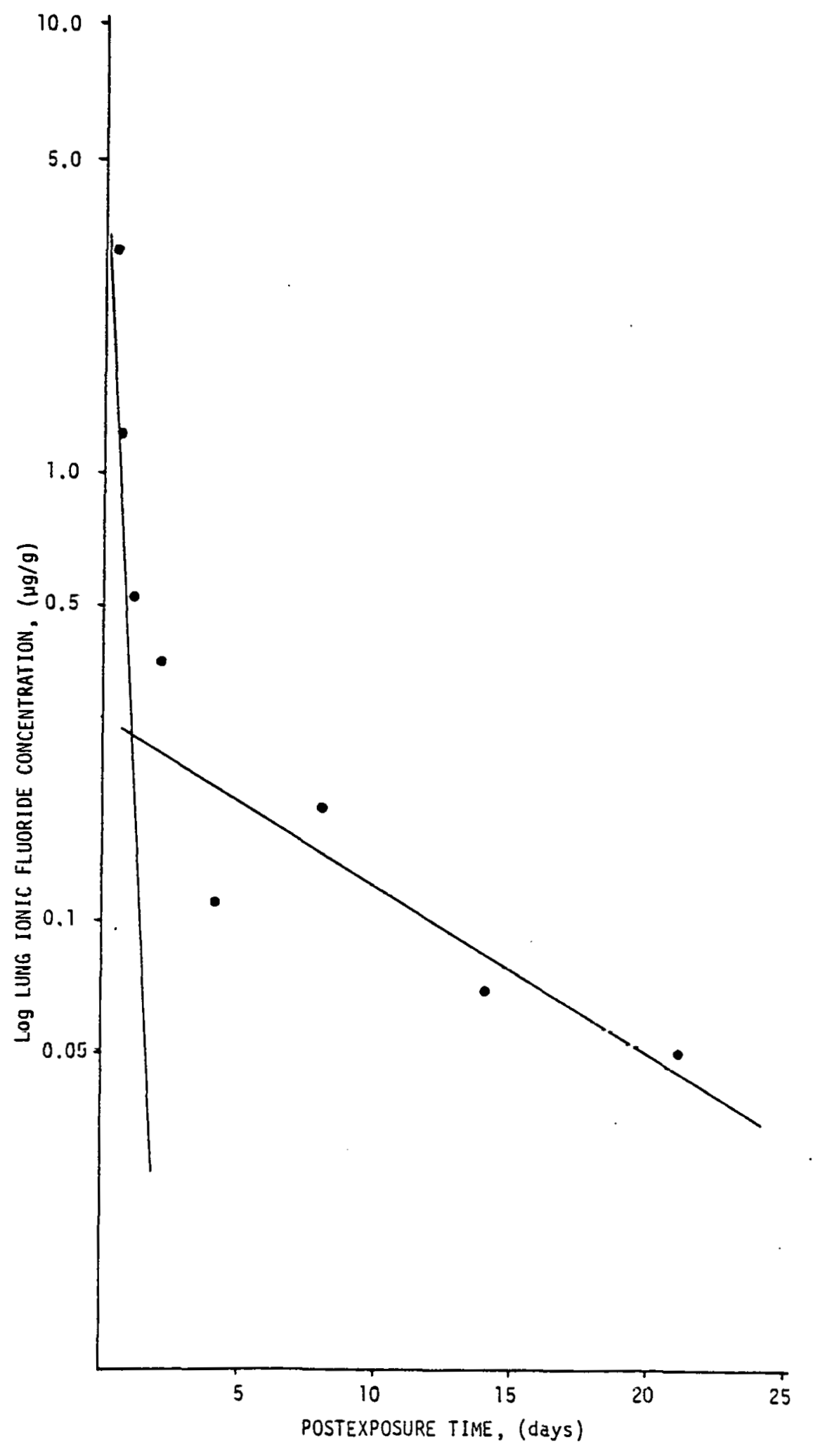


TABLE 28

FLUORIDE RETENTION HALF-TIMES IN'SOFT TISSUES OF RATS EXPOSED TO $10.2 \mathrm{mg} \mathrm{F} / \mathrm{m}^{3}$ HF FOR 6 HOURS 1

$\underline{\text { Tissue }}$

Lung

ionic $F^{-}$

total $F 3$

Plasma

$\begin{array}{rr}\text { ionic } \mathrm{F}^{-} & 8 \% \\ \text { total }=3 & 92 \%\end{array}$

Kidney

$\begin{array}{lr}\text { ionic F- } & 5 \% \\ \text { total F } 3 & 95 \% \\ & 12 \%\end{array}$

Retention

half-time

$95 \%$ C.L. 2

days half-time

(days)

\% Initial burden$$
\text { (days) }
$$

8

0.2

9
17

0.6

10

33

0.5

23
$6-12$

$0.16-.40$

$0.5-0.65$

$12-\infty$

$0.4-0.6$

1 Retention half-times were calculated using mean tissue ionic or total fluoride concentration at each sacrifice time. HF generated by compressed gas technique.

$295 \%$ confidence limits.

3 The retention half-time for the long term component was calculated using total fluoride concentration and is given for comparison with the value obtained using ionic fluoride concentration for the calculations. 
experiment, an interesting result is obtained. For this rough estimation the long term phase of pulmonary fluoride retention is ignored; it is assumed that 1008 of the fluoride is cleared with a half-time of 0.2 days. It is also assumed that $\mathrm{HF}$ enters the lung at a constant rate equal to the average airborne concentration $\left(10.2 \mathrm{mg} \mathrm{F} / \mathrm{m}^{3}\right)$ times the ventilation rate $(0.15 \mathrm{liter} / \mathrm{min})$. With these assumptions a pulmonary fluoride burden of $369 \mu \mathrm{g}$ or 260 $\mu \mathrm{g} / \mathrm{g}$ (mean lung weight $1.42 \mathrm{grams}$ ) is obtained. If the long term component of fluoride retention is not ignored an even larger estimate is obtained. The large discrepancy between this estimate and the value of $3.27 \mu \mathrm{g} / \mathrm{g}$ measured in rats sacrificed 5-65 minutes postexposure suggests that some important factor has not been considered. Two possible explanations for this discrepancy are 1) only a small fraction of the $\mathrm{HF}$ inhaled is deposited in the lung (i.e., it may be removed in the upper respiratory tract) or 2), there is a very rapid clearance of fluoride ion from the lung that was not detected in this experiment (i.e., the lung fluoride concentration decreased from $260 \mu \mathrm{g} / \mathrm{g}$ to $3.27 \mu \mathrm{g} / \mathrm{g}$ in the first 5 minutes of the postexposure period).

The $\Delta F$ concentrations in soft tissues of rats sacrificed after exposure to $10.2 \mathrm{mg} \mathrm{F} / \mathrm{m}^{3}$ are given in Table 29. At no sacrifice time were the $\Delta F$ concentrations in lung and plasma significantly elevated over control levels. $\Delta F$ concentration in the kidneys of exposed animals sacrificed on days $1 / 4,1 / 2,4$ and 8 were significantly higher than control levels, but the differences between exposed and control kidney $\Delta F$ concentrations were never 
TABLE 29

$\triangle F$ CONCENTRATION IN SOFT TISSUES OF RATS SACRIFICED

SERIALLY AFTER EXPOSURE TO $10.2 \mathrm{mg} \mathrm{F} / \mathrm{m}^{3}$ HF FOR 6 HOURS 1

Sacrifice Day
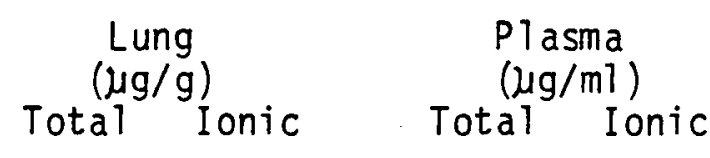

Kidney

Total Ionic

0.63

3.7

0.4

3

0.10

.12

.08

(5)

(5)

(6)

(6)

$0.52-.01$

0.2

.10

(5)

(6)

(6)

(5)

0.6
.1

0.27
.08

0.01

1.2
.1

(5)

(6)

.03

(5)

(6)

.07

. 2

0.11

1.1
.2

(5)

(5)

(6)

0.03

.01

(6)

4

0.9

i 2

0.7

(5)

0.09

.02

(6)

0.03

.02

(6)

8

0.9

(5)

(5)

0.8

$i^{2}$

(5)

0.09

0.02

.01

(0)

14

$0.5 \quad 0.4$

(5)

(5)

0.13

.03

(6)

(6)

0.08

.03

(6)

21

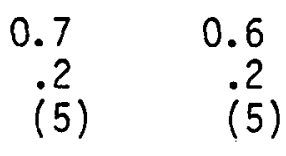

.2
(5)

0.08

.00

(6)

0.03

.01

(6)

28

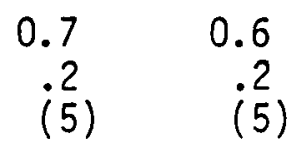

0.09

0.05
.03
$(6)$

(6)

42

$\begin{array}{rrrr}0.5 & 0.4 & 0.00 & -0.04 \\ i 1 & .1 & .01 & .01 \\ (5) & (5) & (6) & (6)\end{array}$

$(\mu \mathrm{g} / \mathrm{g})$

Total Ionic

$2.1 \quad 0.6^{a}$

(6) $i^{2}$

$1.7 \quad 0.4^{\mathrm{a}}$

(6) $\quad 11$

$\begin{array}{ll}0.8 & 0.2 \\ .1 & .1\end{array}$

(6) (6)

$\begin{array}{rr}0.8 & 0.5 \\ .2 & .2\end{array}$

(6) (6)

$0.5 \quad 0.4$

(6) $\quad(1)$

$0.6 \quad 0.5$

(6) $\quad$ i 6

$0.5 \quad 0.4$

(6) $\quad(1)$

$0.4 \quad 0.3$

(6) $\quad .1$

(6) (6)

$\begin{array}{rr}0.3 & 0.2 \\ i 1 & .1 \\ (6) & (6)\end{array}$

$0.3 \quad 0.2$

(6) $\quad(1$ 
TABLE 29 (continued)

$\triangle F$ CONCENTRATION IN SOFT TISSUES OF RATS SACRIFICED SERIALLY AFTER EXPOSURE TO $10.2 \mathrm{mg} \mathrm{F} / \mathrm{m}^{3} \mathrm{HF}$ FOR 6 HOURS

Sacrifice Day

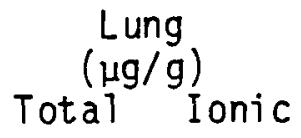
Pl asma
$(\mu \mathrm{g} / \mathrm{ml})$ Total Ionic

Kidney Total Ionic Total

$(\mu \mathrm{g} / \mathrm{g})$ Total Ionic

control

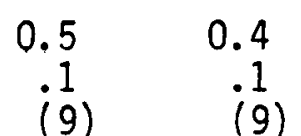

0.08

0.05

.01

.01

(9)

(9)

0.1

.0

(9)

0.1

1 Values expressed as mean, S.E.M., (number of animals per group). HF generated by compressed gas system.

a $p<0.05$ compared to control

b $p<0.01$ compared to control. 
larger that the analytical error of the total fluoride technique (total kidney fluoride can be determined $\pm 0.3 \mu \mathrm{g} / \mathrm{g}$ ). However, the consistancy of the increased $\Delta F$ concentration in kidneys of rats exposed to HF suggests that elevated levels of $\Delta F$ were actually present.

Femurs from control and exposed animals sacrificed on days 2 , 8,28 , and 42 were analyzed for total fluoride content. The mean and standard error for each group are plotted against postexposure time in Figure 18. The amount of fluoride in the femur increased with postexposure time in both control and exposed animals. On days $2,8,42$ the amount of fluoride in the femurs of exposed animals was significantly higher than in controls. The arithmetic mean femoral fluoride content for the exposed and control groups were subjected to a linear regression. In both cases a significant correlation existed (exposed: $\quad r=.989$, df $=2, p<0.05$; control: $r=.999, \mathrm{df}=2, p<0.01)$. Exposed animals deposited an average of $5.43 \mathrm{\mu g} F$ per femur per day; in control animals this rate was $3.09 \mathrm{\mu g}$ per femur per day. These two rates are significantly different $\left(F_{1,4}=16.2, p<0.05\right)$.

The fluoride excretion in urine and feces during the postexposure period is shown in Table 30. Total fluoride content was analyzed in feces and is expressed in $\mu \mathrm{g} / \mathrm{g}$ dry weight. The concentration of fluoride in feces of both control and exposed animals was fairly constant, but the total amount of fluoride excreted via this route was extremely variable because the fecal mass varied considerably. The mean fecal mass per day in fed rats 
FIGURE 18

Femoral fluoride content of control and $10.2 \mathrm{mg} \mathrm{F} / \mathrm{m}^{3} \mathrm{HF}$ exposed rats versus postexposure time. Each vertical line represents plus or minus one S.E.M. The linear regression lines for the control and exposed groups are shown. 


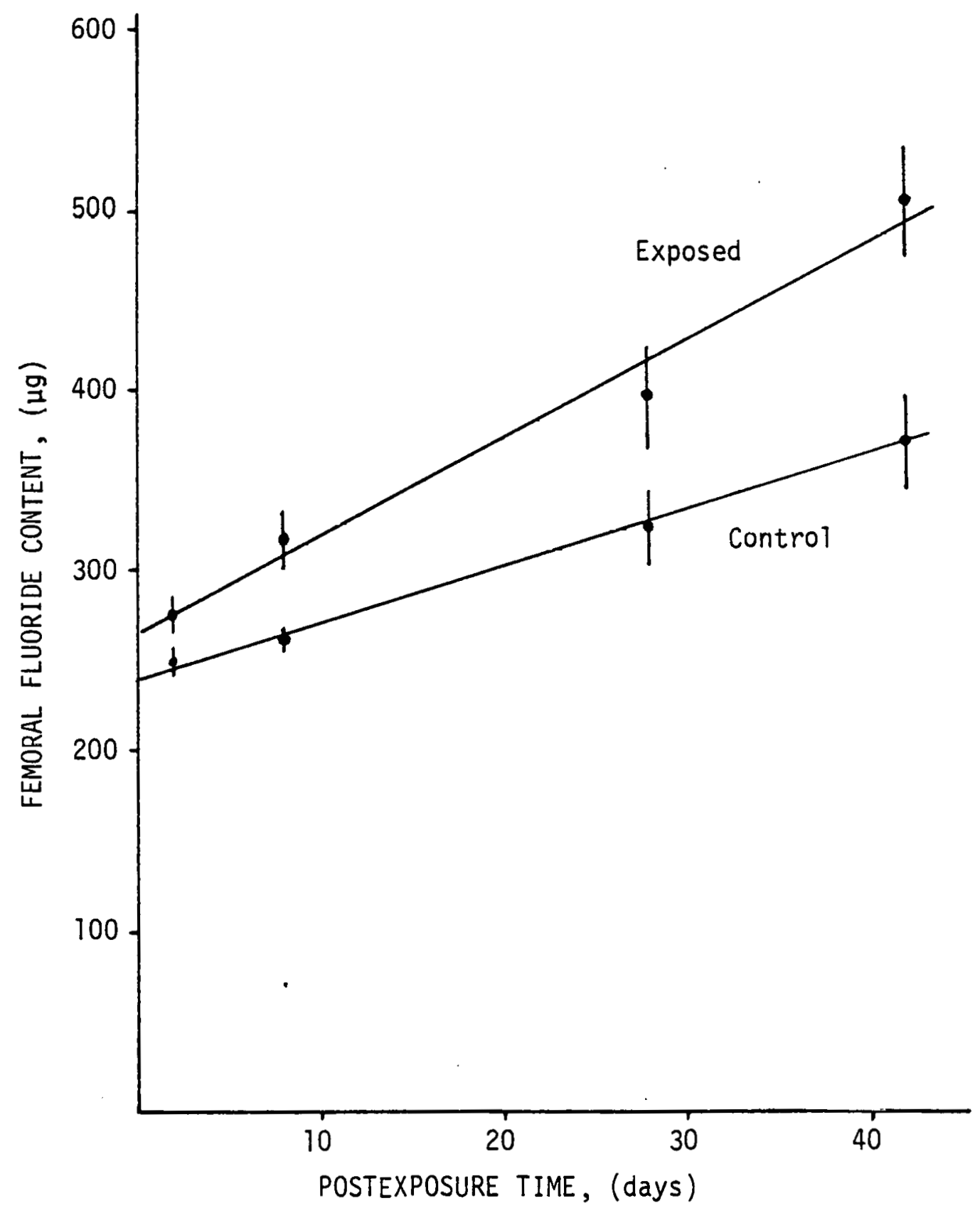


TABLE 30

URINARY IONIC FLUORIDE EXCRETION AND TOTAL FECAL FLUORIDE CONCENTRATION AFTER EXPOSURE TO $10.2 \mathrm{mg} \mathrm{F} / \mathrm{m}^{3}$ FOR 6 HOURS 1

Collection period
(day)

Urinary Ionic $\mathrm{F}^{-}$

$(\mu \mathrm{g} / \mathrm{day})$

\section{Control}

16

43

6

(6)

$1-2$

57
4

(6)

$2-3$

$3-4$

$4-5$

$5-6$

$6-7$

$7-8^{2}$

$9-10$

53

(5)

51

(6)

6)

6.

(6)

$124 b$

13

(6)

$94 b$

5

(6)

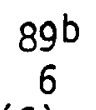

(6)

66

(4)

Fecal Total $F$ $(\mu \mathrm{g} / \mathrm{g})$

Control Exposed

$106^{b}$

3

(6)

$215^{b}$

27

(6)

$163^{b}$

5

$25 \mathrm{~b}$

(6)

$89 b$

$88 \mathrm{a}$

4

$100^{b}$

12

(6)

64

5

(4)

715

$95 a$

3

(6)

(5)

$11-12$

$71^{b}$

3

(6) 
TABLE 30 (continued)

URINARY IONIC FLUORIDE EXCRETION AND TOTAL FECAL FLUORIDE CONCENTRATION AFTER EXPOSURE TO $10.2 \mathrm{mg} \mathrm{F} / \mathrm{m}^{3}$ FOR 6 HOURS 1

Collection period (day)

Urinary Ionic $\mathrm{F}^{-}$ ( $\mu \mathrm{g} /$ day)

Control Exposed
Fecal Total $F$ $(\mu \mathrm{g} / \mathrm{g})$

Control Exposed
$13-142$

$20-212$

$27-282$

$41-422$
51

51
3
$(6)$

51
3
$(6)$

$69 b$

2

(6)

$69 \mathrm{a}$

7

(6)

$48 \quad 79 b$

7

(6)

59

7

(6)
4

(6)

$63^{a}$

4

(6)
75

3

(4)

83

5

(6)

$87^{a}$

5

80

(5)

70

(5)

82

6

(5)

Entire control group mean

S.E.M.

(n)

52

20

(7)

71

4.

(4)

1 Values expressed as mean, S.E.M., (number of animals per group). HF generated by compressed gas téchn1que.

2 Rats fasted during collection period

3 Calculated using mean value for each control group.

a $p<0.05$ compared to entire control group.

b $\quad p<0.01$ compared to entire control group. 
was $3.7 \mathrm{~g} \pm 2.0$ (24) [mean \pm std. dev., (number of samples)] • These values for fasted animals were $0.7 \mathrm{~g} \pm 0.6$ (24). The mean fecal fluoride concentrations on each control day analyzed were used to calculate the mean fecal fluoride concentration for the entire control group. The fluoride concentration in feces collected from exposed animals on days 2, 4, 7, 10 and 21 was statistically higher than the control group. However, only on days 2 and 4 were the fecal $F$ concentrations markedly elevated. Using the mean fecal mass of $3.7 \mathrm{~g}$ per day fed control animals excrete a mean of $263 \mu \mathrm{g}$ fluoride/day by this route. On day 2 after inhalation of HF animals excreted a mean of $800 \mu \mathrm{g}$ fluoride (215 $\mu g \times 3.7 \mathrm{~g})$ by the fecal route. On day 4 postexposure the fecal fluoride excretion is calculated to be $390 \mu \mathrm{g}$. On days 2 and 4 exposed animals excreted $190 \mu \mathrm{g}$ and $73 \mu \mathrm{g}$, respectively, more fluoride in their urine than did control animals (using the mean excretion for the entire control group for reference). Thus it is evident that shortly following exposure to $\mathrm{HF}$ animals excrete more fluoride via the GI tract than through the kidneys.

The urinary ionic fluoride excretion in control animals remained constant throughout the 42 day postexposure period. The mean urinary ionic fluoride excretion for the entire control group was calculated in the same manner as for control fecal fluoride. Urinary fluoride excretion increased rapidly following exposure to HF. Exposed animals excreted almost 10 fold more fluoride during the first 6 hours and the first 18 hours postexposure than control animals. Urinary fluoride excretion slowly decreased in exposed 
animals but by day 28 had not returned to control levels. The urinary fluoride excretion in exposed animals on day 42 was significantly higher than the entire control group, but not higher than in control rats on day 42 .

The logarithm of urinary fluoride excretion corrected for controls is plotted versus postexposure time in Figure 19. This curve was analyzed in the same manner as for the soft tissue data. Urinary fluoride excretion following $\mathrm{HF}$ exposure also appears to be biphasic. Approximately one-half of the cumulative fluoride excreted via this route was excreted with a half-time of 1.7 days (958 confidence limits: 1.2 day $<T 1 / 2<3.0$ day). The remaining fluoride was excreted with a half-time of 63 days (958 confidence limits 31 to $\infty$ ). The equation obtained for urinary fluoride excretion (U) after $\mathrm{HF}$ exposure was:

$$
U=389 \mu \mathrm{g} \mathrm{e}^{-0.41 t}+22.4 \mu \mathrm{g} \mathrm{e}^{-0.011 t}
$$

with the fractional decay constants given in day ${ }^{-1}$. The cumulative fluoride excreted during the 42 day postexposure period obtained by adding the measured fluoride excreted on days 1-8 to the fluoride excretion calculated by the equation given above for days 9-42 was $1598 \mu \mathrm{g}$. Since each point was corrected for control levels prior to mathematical analysis, this value, 1598 $\mu g$, I epresents the calculated excess fluorlde excretion during the postexpusure period.

Urine samples obtained on each sacrifice day were pooled and then ashed for determination of total fluoride content. The results of this analysis are given in Table 31. As can be seen 
FIGURE 19

Log of the mean daily urinary ionic fluoride excretion following exposure to $10.2 \mathrm{mg} \mathrm{F} / \mathrm{m}^{3} \mathrm{HF}$ versus postexposure time. The 1 inear regression lines are shown. 


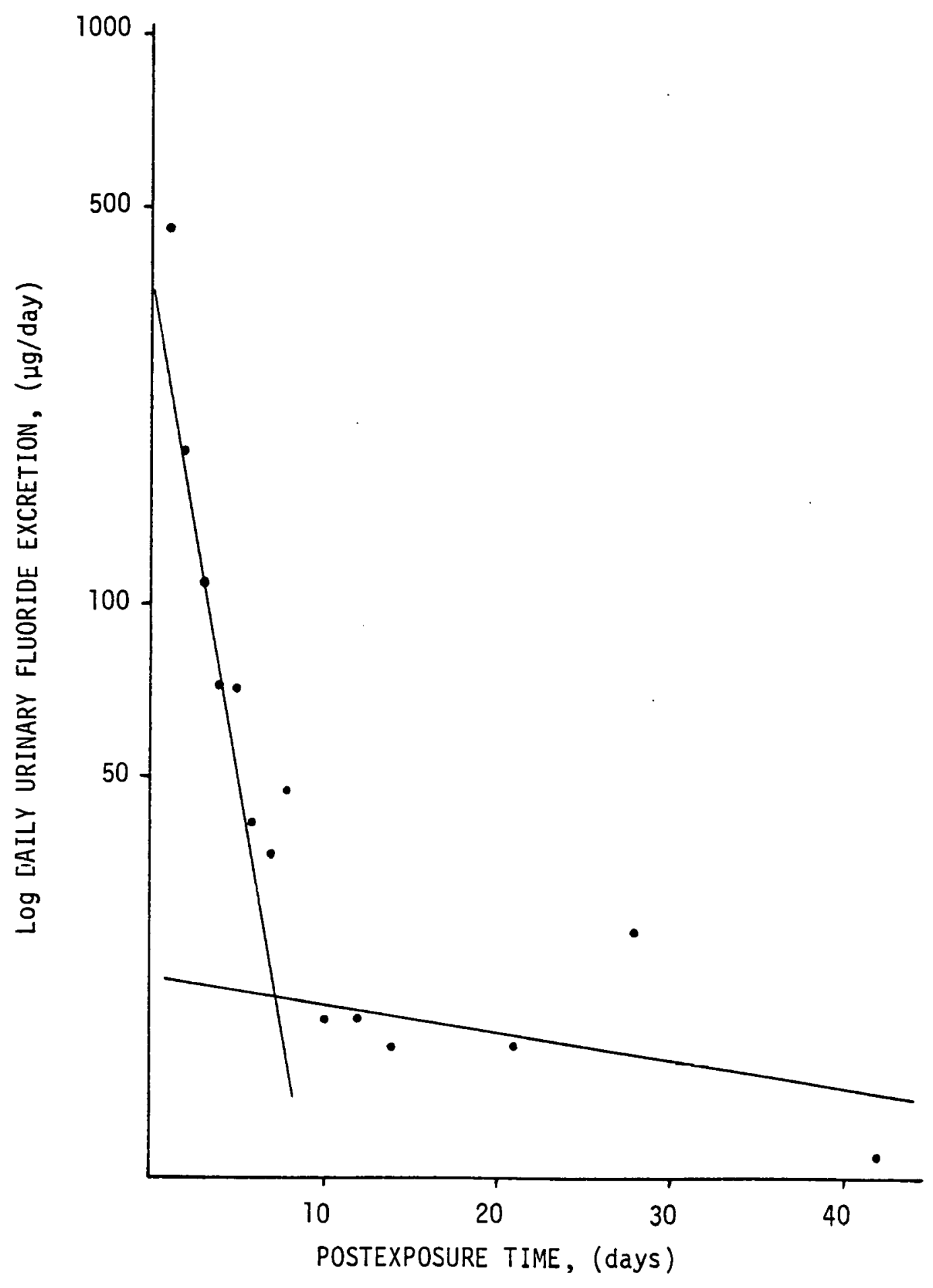




\section{TABLE 31}

\section{$\triangle F$ CONCENTRATION IN URINE AFTER EXPOSURE TO} $10.2 \mathrm{mg} \mathrm{F} / \mathrm{m}^{3}$ HF FOR 6 HOURS 1

\begin{tabular}{|c|c|c|c|c|c|c|}
\hline $\begin{array}{l}\text { Collection period } \\
\text { (day) }\end{array}$ & & $\begin{array}{l}\text { Exposec } \\
(\mu \mathrm{g} / \mathrm{ml})\end{array}$ & & & $\begin{array}{l}\text { Control } \\
(\mu g / m l)\end{array}$ & \\
\hline & Total & Ionic & $\Delta F$ & Total & Ionic & $\Delta F$ \\
\hline$\frac{1}{4}-\frac{1}{2}$ & 44. & 44. & 0. & 3.1 & 3.2 & -0.1 \\
\hline$\frac{3}{4}-1$ & 34. & 40. & -6 & 3.2 & 3.0 & 0.2 \\
\hline $1-2$ & 12. & 13. & -1 & 4.5 & 3.7 & 0.8 \\
\hline $3-4$ & 7.5 & -7.6 & -0.1 & 2.6 & 2.7 & -0.1 \\
\hline $7-8$ & 5.1 & 5.0 & -0.1 & 2.9 & 2.4 & -0.5 \\
\hline $13-14$ & 3.8 & 4.5 & -0.7 & 2.7 & 3.5 & -0.8 \\
\hline $20-21$ & 2.8 & 3.3 & -0.5 & & & \\
\hline $27-28$ & 4.0 & 4.0 & 0.0 & 3.2 & 3.1 & 0.1 \\
\hline $41-42$ & 3.2 & 3.0 & 0.2 & 2.6 & 2.7 & -0.1 \\
\hline
\end{tabular}

1 Urines from each rat were pooled by group prior to determination of fluoride concentration. The value for each pool is reported individually. Fluoride concentrations not corrected for the cage wash water. HF generated by compressed gas technique. 
significant amounts of $\Delta F$ were not detected in the urine of control or exposed animals. Since total urine fluoride equalled ionic urine fluoride, similar results would be obtained if either of these values were uesd in the calculations described above. Ionic fluoride concentrations were used because this analytical technique is more precise and sensitive than the total $F$ technique. The femoral and urinary fluoride data from exposed animals are compared in Table 32. Previous investigations on fluoride distribution and excretion have indicated that approximately $50 \%$ of absorbed fluoride is excreted via the urine (Smith, 1966), the remainder is deposited in bone. The excess fluoride per femur (obtained by subtracting the appropriate mean control femoral fluoride content from the exposed animal femoral fluoride) in HF exposed animals is divided by 0.0465 (femur ash weight averages 4.658 of the total skeletal ash, Savchuck and Armstrong, 1951) to estimate the excess fluoride present in the entire skeleton. This calculation assumes that the femur is a representative sample of the skeleton. The validity of this assumption has been shown by Savchuck and Armstrong (1951). Also given in this Table is the cumulative excess fluoride excretion, which was calculated as described above. This was added to the excess fluoride per skeleton to estimate the cumulative absorbed fluoride. This assumes that all of the fluoride absorbed appears in the urine or skeleton. These estimates are only valid for very rough comparisons. The number of significant figures for each value reported in the table is not meant in any way to give information 
TABLE 32

COMPARISON OF URINARY F EXCRETION AND FEMORAL FLUORIDE RETENTION 1

\begin{tabular}{ccccc}
$\begin{array}{c}\text { Postexposure } \\
\text { day }\end{array}$ & $\begin{array}{c}\text { Excess } F \\
\text { per femur } \\
(\mu \mathrm{g})\end{array}$ & $\begin{array}{c}\text { Estimated excess } F \\
\text { per skeleton } \\
(\mu \mathrm{g})\end{array}$ & $-\begin{array}{c}\text { Cumulative excess } \\
\text { urinary } F \text { excretion } \\
(\mu \mathrm{g})\end{array}$ & $\begin{array}{c}\text { Estimated Cumulative } \\
\text { absorbed } \\
(\mu \mathrm{g})\end{array}$ \\
\hline 2 & -581 & 633 & 1214 \\
8 & 27 & 1183 & 1016 & 2199 \\
28 & 55 & 1548 & 1384 & 2932 \\
42 & 72 & 2882 & 1598 & 4480
\end{tabular}

1 See text for explanation of calculations. 
on the accuracy of these estimates. Roughly equal amounts of fluoride are excreted in the urine and deposited in the skeleton of these rats. These results suggest that the HF exposed animals absorbed approximately $4500 \mu \mathrm{g}$ of fluoride as a result of $\mathrm{HF}$ exposure. Using a ventilation rate of $150 \mathrm{cc} / \mathrm{min}$ and a mean airborne fluoride concentration of $10.2 \mathrm{mg} / \mathrm{m}^{3}$ it can be estimated that these exposed rats inhaled $550 \mu \mathrm{g}$ of fluoride during the 6 hour exposure. These two estimates of absorbed fluoride are not in good agreement. Apparently HF exposed rats are absorbing much greater anounts (nearly 10 fold) of fluoride than could be explained by the inhalation of HF.

While there is no direct information on the subject the source of the excess fluoride may be the fur. Rats preen, and if large amounts of HF were to absorb to the fur during whole body exposure it seems likely that large amounts of fluoride would be ingested orally. In an empty exposure chamber, airborne fluoride levels of approximately $84 \mathrm{mg} \mathrm{F} / \mathrm{m}^{3}$ were obtained with a HF regulator pressure of $15 \mathrm{lb} / \mathrm{in}^{2}$ (Table 5), however with 6 rats in the chamber an airborne fluoride concentration of only $27 \mathrm{mg} \mathrm{F} / \mathrm{m}^{3}$ was produced with the same regulator pressure (Table 5). Thus the chamber operating characteristics suggest that rats remove large amounts of fluoride from the air, certainly more than can be accounted for on the basis of their pulmonary ventilation since the total airflow rate in the chamber was 28 liters/minute. Because of the magnitude of this additional source of fluoride the results of these whole exposures do not give any direct information on the metabolism of inhaled HF. 
D. NaF Retention Experiment

To obtain data for comparison to HF exposures male Long Evans rats (Blue Spruce Farms) were exposed to NaF dust for 6 hours in a 28 liter glass battery jar inhalation chamber. Prior to exposure a two-minute chamber air sample was drawn through a Mercer impactor (Mercer, et al., 1970) at a flow rate of $0.7021 / \mathrm{min}$ for determination of particle size. The dust contained on each slide and the filter was dissolved in double distilled water and analyzed for fluoride with the fluoride ion sensitive electrode by the known addition technique. The results of these analyses are shown in Figure 20. Fram this log probability plot a mass median aerodynamic diameter of $2.8 \mu \mathrm{m}(\sigma \mathrm{g}=2.2)$ is calculated for the NaF dust. During the exposure several 2 minute air samples $(0.5 \mathrm{l} / \mathrm{min})$ were drawn through a $0.8 \mu \mathrm{m}$ pore size millipore filter for determination of airborne fluoride levels. The time weighted average fluoride concentration for the 6 hour exposure was $24 \mathrm{mg} \mathrm{F} / \mathrm{m}^{3} \mathrm{~F}$ as $\mathrm{NaF}\left(54 \mathrm{mg} / \mathrm{m}^{3}\right.$ dust). The mean chamber temperature during the exposure was $25^{\circ} \mathrm{C}$.

Animals were sacrificed immediately ( $8-60$ minutes) or 8 days postexposure. The animals which were to be kept for 8 days were each submerged in a large beaker of distilled water for a few seconds immediately following the exposure in an attempt to rinse any deposited dust off their fur. These animals were housed individually in metabolism cages and urine and fecal samples were 
FIGURE 20

Log-probability plot of NaF dust collected on each stage of Mercer Impactor . 


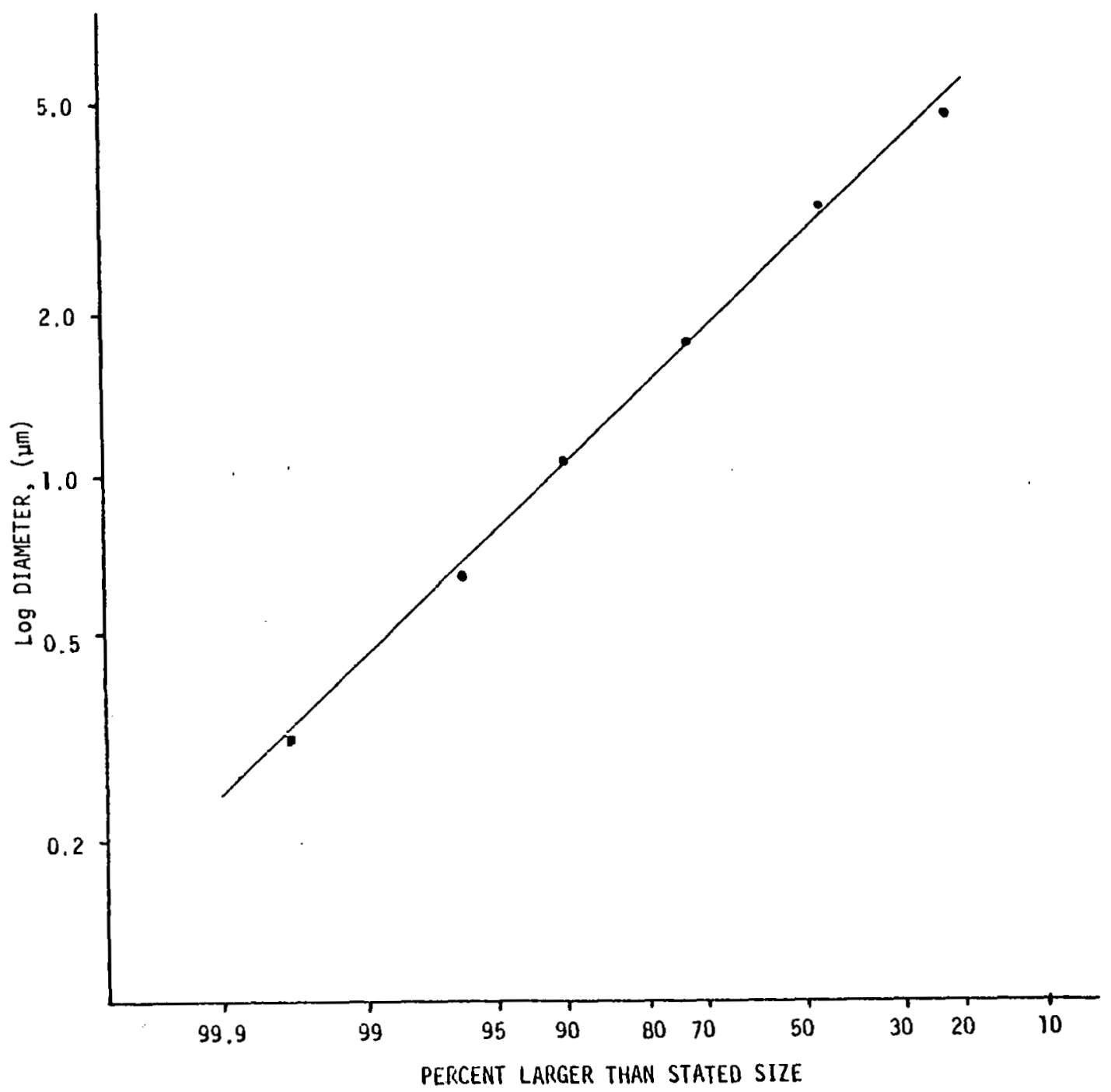


collected throughout the 8 day postexposure period. The animals were fasted during the first and eighth day. Control animals were not chamber exposed and were kept in metabolism cages for 2 days. These animals were fasted on the second day. Since the data for both control days were similar all the data was pooled to obtain the control data given.

The lungs of 2 of the 5 animals sacrificed immediately following NaF exposure appeared diffusely hemorrhagic. No other gross pathologic alteration was noticed upon necropsy. The pulmonary effects of NaF exposure are given in Table 33. The body weights of exposed animals sacrificed on day 8 were statistically lower than control levels, however, the difference of 9 grams out of a $320 \mathrm{gram}$ body weight is probably of no biological significance. No change in the lung to body weight ratio was seen. The lung of exposed animals had a slightly higher water content than control animals as is shown by the significantly higher lung wet weight to dry weight ratios in these animals. Exposure to NaF resulted in a significant alteration in kidney function. Data concerning the kidney function of these animals is given in rable 34 and Figure 21. The kidney weight to body weight ratio was significantly elevated 8 days postexposure. The BUN was significantly elevated immediately postexposure but was no different than control levels 8 days following the exposure. No change in urinary protein excretion was evident. Water consumption 


\section{TABLE 33}

PULMONARY EFFECTS OF EXPOSURE TO $24 \mathrm{mg} \mathrm{F} / \mathrm{m}^{3} \mathrm{NaF}$ FOR 6 HOURS

\begin{tabular}{|c|c|c|c|}
\hline Sacrifice Day & $\begin{array}{l}\text { Body Wt. } \\
(\mathrm{g})\end{array}$ & $\begin{array}{l}\text { Lung Wt. } \\
\text { Body Wt. } \\
(\mathrm{g} / \mathrm{kg})\end{array}$ & $\begin{array}{l}\text { Lung } \\
\text { Wet Wt. } \\
\text { Dry Wt. }\end{array}$ \\
\hline$\frac{1}{4}$ & $\begin{array}{r}329 \\
6 \\
(5)\end{array}$ & $\begin{array}{l}4.67 \\
.10 \\
(5)\end{array}$ & $\begin{array}{l}4.91^{b} \\
(5)^{\circ}\end{array}$ \\
\hline 8 & $\begin{array}{r}311 \\
2 \\
(5)\end{array}$ & $\begin{array}{l}5.02 \\
.10 \\
(5)\end{array}$ & $\begin{array}{l}4.75^{b} \\
.02 \\
(5)^{2}\end{array}$ \\
\hline control & $\begin{array}{r}320 \\
3 \\
(3)^{3}\end{array}$ & $\begin{array}{l}5.20 \\
(35)\end{array}$ & $\begin{array}{l}4.62 \\
.02 \\
(3)\end{array}$ \\
\hline
\end{tabular}

1 Values expressed as mean, S.E.M. (number of animals per group). b $\quad p<0.01$ compared to control. 
TABLE 34

RENAL EFFECTS OF EXPOSURE TO $24 \mathrm{mg} / \mathrm{m}^{3} \mathrm{NaF}$ FOR 6 HOURS 1

\begin{tabular}{|c|c|c|c|c|}
\hline Sacrifice Day & 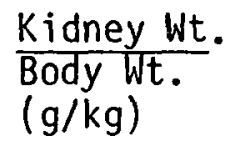 & $\begin{array}{l}\text { BUN } \\
(\mathrm{mg} \%)\end{array}$ & $\begin{array}{l}\text { Water consumption } \\
(\mathrm{ml} / \text { day })\end{array}$ & $\begin{array}{l}\text { Protein excretion } \\
\mathrm{mg} / \text { day }\end{array}$ \\
\hline$\frac{1}{4}$ & $\begin{array}{l}6.61 \\
(.09 \\
(5)\end{array}$ & $\begin{array}{l}22.5^{\mathrm{b}} \\
2.0^{\circ} \\
(5)^{-}\end{array}$ & & \\
\hline 12 & & & $\begin{array}{c}13.2 \\
3.2 \\
(5)^{2}\end{array}$ & $\begin{array}{r}47 . \\
6 \\
(5)\end{array}$ \\
\hline 2 & & & $\begin{array}{l}32.2^{a} \\
6.3^{3} \\
(5)^{2}\end{array}$ & $\begin{array}{r}85 . \\
9 \\
(5)\end{array}$ \\
\hline 3 & & & $\begin{array}{c}45.4^{b} \\
5.2^{2} \\
(5)^{-}\end{array}$ & $\begin{array}{l}98 . \\
15 \\
(5)\end{array}$ \\
\hline 4 & & & $\begin{array}{l}54 . \quad b \\
3.2^{2} \\
(5)^{-}\end{array}$ & $\begin{array}{c}116 . \\
9)^{\circ}\end{array}$ \\
\hline 5 & & & $\begin{array}{l}15.0 \\
3.0 \\
(5)\end{array}$ & $\begin{array}{c}101 . \\
8 . \\
(5)\end{array}$ \\
\hline 6 & & & $\begin{array}{l}60.2^{\mathrm{b}} \\
6.5 \\
(5)^{-}\end{array}$ & $\begin{array}{l}123 . \\
3 . \\
(5)\end{array}$ \\
\hline
\end{tabular}


TABLE 34 (continued)

RENAL EFFECTS OF EXPOSURE TO $24 \mathrm{mg} \mathrm{F} / \mathrm{m}^{3} \mathrm{NaF}$ FOR 6 HOURS 1

\begin{tabular}{|c|c|c|c|c|}
\hline Sacrifice Day & $\begin{array}{l}\text { Kidney Wt. } \\
\text { Body Wt. } \\
(\mathrm{g} / \mathrm{kg})\end{array}$ & $\begin{array}{l}\text { BUN } \\
(\mathrm{mg} \%)\end{array}$ & $\begin{array}{c}\text { Water consumption } \\
(\mathrm{ml} / \text { day })\end{array}$ & $\begin{array}{c}\text { Protein excretion } \\
\text { mg/day }\end{array}$ \\
\hline 7 & & & $\begin{array}{l}38 . i^{b} \\
1.9)^{-}\end{array}$ & $\begin{array}{r}127 . \\
9\end{array}$ \\
\hline 82 & $\begin{array}{c}7.61 \mathrm{~b} \\
.14 \\
(5)\end{array}$ & $\begin{array}{r}15.1 \\
.9 \\
(5)\end{array}$ & $\begin{array}{l}17 \\
3.6 \\
(5)\end{array}$ & $\begin{array}{r}104 \\
7 \\
(5)\end{array}$ \\
\hline Control & $\begin{array}{r}6.71 \\
.20 \\
(3)\end{array}$ & $\begin{array}{r}14.5 \\
(3)^{5}\end{array}$ & $\begin{array}{l}15 . \\
4.2 \\
(6)\end{array}$ & $\begin{array}{l}99 . \\
13 \\
(6)\end{array}$ \\
\hline
\end{tabular}

1 Values expressed as mean, S.E.M., (number of animals per group)

2 Rats fasted during these days.

a $\quad p<0.05$ compared to control

b $\quad p<0.01$ compared to control 


\section{FIGURE 21}

Urine volume and specific gravity following exposure to

$24 \mathrm{mg} \mathrm{F} / \mathrm{m}^{3} \mathrm{NaF}$ versus postexposure time. Daily urine samples

were collected. Mean \pm S.E.M. is shown. The horizontal lines

represent \pm one S.E.M. of the mean control value. 

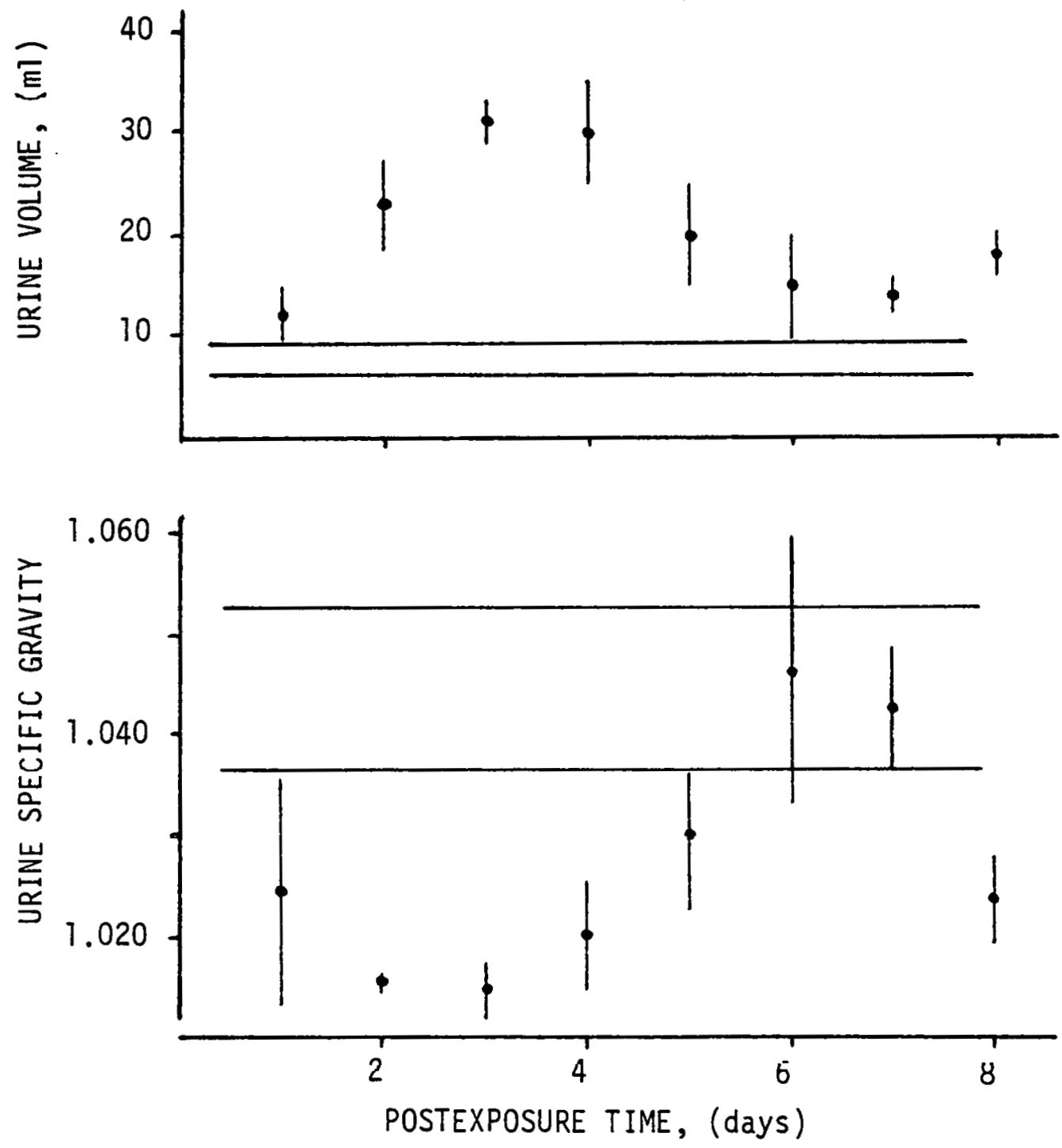
was significantly higher than control levels in exposed animals on days 2, 3, 4, 6 and 7 following exposure. No increase in water consumption was seen on day 5 because the water bottles were emptied. This may have also affected the water consumption on day 6 . In Figure 21 urine volume and specific gravity are plotted against postexposure day. Urine volume was significantly elevated on days 2, 3, 4 and 8 postexposure. Peak urine volume occurred on day 3 and was almost 4-fold higher than control levels. Urine specific gravity was significantly lower than control values on days $2,3,4$ and 8 postexposure. The maximum depression occurred on day 3 . The total and ionic fluoride concentration in lung, plasma and kidney of $r$ ats exposed to $\mathrm{NaF}$ are given in Table 35. The ionic fluoride concentration in soft tissues of control rats were measured, but the samples were lost prior to determination of total fluoride content. Total and ionic fluoride concentrations were elevated over control levels by NaF exposures. In rats sacrificed 8 days after exposure the ionic fluoride concentration in lung averaged 2.2 times that in plasma. In plasma of rats sacrificed immediately postexposure ( $1 / 4$ day group) the measured total plasma fluoride concentration averaged 818 of the ionic fluoride concentration (see second paragraph following).

The $\Delta \mathrm{F}$ concentrations in lung, plasma and kidney of rats exposed to $\mathrm{NaF}$ are given in.Table 36. $\Delta \mathrm{F}$ accounted for 238 of the total fluoride in lungs of rats sacrificed immediately after NaF exposure. The mean total fluoride concentration in lung 
MEASURED FLUORIDE CONCENTRATION IN SOFT TISSUES OF RATS EXPOSED TO $24 \mathrm{mg} \mathrm{F} / \mathrm{m}^{3}$ NaF FOR 6 HOURS 1

Sacrifice day

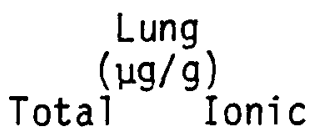

21. $\quad 14.9$
3.7

(5)

1.0

(5)

Control 2

(5)

8

2

2.7

$\begin{array}{ll}.0 & .60 \\ 26 & .17 \\ 5) & (5)\end{array}$

0.11 $\begin{array}{cc}\text { Plasma } & \text { Kidney } \\ (\mu \mathrm{g} / \mathrm{ml}) & (\mu \mathrm{g} / \mathrm{g}) \\ \text { Total Ionic } & \text { Total Ionic }\end{array}$

3.51

.25

(5)

.28

.05

(5)

4.32

.44

(5)

.27

.06

(5)

0.045
26. $\quad 23.4$

$4.2 \quad 4.9$

(5)

(5)
$2.8 \quad 1.56$
$.64 \quad .45$

(5)

1 Values expressed as mean, S.E.M., (number of animals per group).

2 Tissues from contol rats were pooled by group ( 3 rats per group) The fluoride concentration measured in the tissue pool is reported. 
TABLE 36

$\triangle F$ CONCENTRATIONS IN SOFT TISSUES OF RATS EXPOSED TO $24 \mathrm{mg} \mathrm{F} / \mathrm{m}^{3} \mathrm{NaF}$ FOR 6 HOURS 1

Sacrifice day

$\frac{1}{4}$

8 day

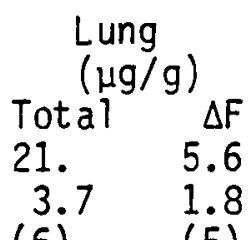

(6)

1.0

$\left(\dot{5}^{3}\right.$
$\Delta \mathrm{F}$

1.8

(5)

0.4

.2

$(5)$

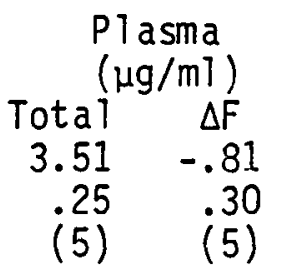

$.28 \quad .01$

$.05 \quad .01$

(5) (5)

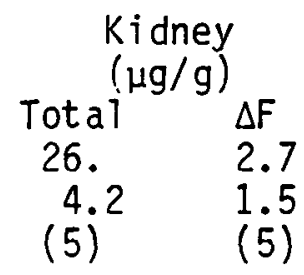

$2.8 \quad 1.3$

$.64 \quad .3$

(5) (5)

1 Values expressed as mean, S.E.M., (number of animals per group). Total and $\Delta F$ concentration in lung, $p l$ asma and kidney of control rats sacrificed in the HF retention experiment averaged 0.5 and $0.4 \mu \mathrm{g} / \mathrm{g}, 0.08$ and $0.05 \mu \mathrm{g} / \mathrm{ml}$ and 0.1 and $0.1 \mu \mathrm{g} / \mathrm{g}$, respectively. 
homogenates was $5.3 \mu \mathrm{g} / \mathrm{ml}$. The solubility of $\mathrm{NaF}$ in water is approximately $42,000 \mu \mathrm{g} / \mathrm{ml}$ suggesting that the $\Delta \mathrm{F}$ in these lungs is not undissolved NaF dust. In animals sacrificed 8 days postexposure the $\Delta F$ concentration in lungs were at levels normally present in control rat tissues.

Elevated $\Delta F$ concentrations were detected in the kidneys of rats sacrified immediately and 8 days after exposure to NaF.

The mean $\Delta \mathrm{F}$ concentration obtained in plasma of rats sacrificed immediately after NaF exposure was $-0.81 \mu \mathrm{g} / \mathrm{ml}$. This anomolous result points out the problems involved in the determination of $\Delta F$ concentration. Both fluoride methods are imprecise; occasionally negative values for $\Delta F$ would be expected because of randan analytical error. This result emphasizes that the detection of $\Delta F$ in a tissue of one group of animals does not prove that a true non-ionic fluoride compound exists in that tissue. The fluoride excreted in urine and feces and the femoral fluoride content of rats after exposure to NaF are given in Table 37. The urinary fluoride excretion was significantly higher than control levels on every postexposure day, urinary fluoride excretion on day 8 averaging 6 times the control level. Exposed animals excreted an excess of $9290 \mu \mathrm{g}$ fluoride during the 8 day postexposure period. Large amounts of fluoride were also excreted in the feces of exposed animals. Peak fecal fluoride concentrations appeared on day 2 and were 47 fold higher than 
TABLE 37

FLUORIDE EXCRETION AND FEMORAL FLUORIDE CONTENT OF RATS FOLLOWING EXPOSURE TO $24 \mathrm{mg} \mathrm{F} / \mathrm{m}^{3} \mathrm{NaF}$ FOR 6 HOURS

\begin{tabular}{|c|c|c|c|c|}
\hline Sacrifice day & $\begin{array}{l}\text { Urinary Ionic } \\
F^{-} \text {Excretion } \\
\text { ( } \mu \mathrm{g} / \text { day })\end{array}$ & $\begin{array}{l}\text { Fecal Total }{ }^{2} \\
F \text { concentration } \\
(\mu g / g)\end{array}$ & $\begin{array}{l}\text { Fecal Total } 3 \\
\mathrm{~F} \text { excretion } \\
(\mu \mathrm{g} / \text { day })\end{array}$ & $\begin{array}{l}\text { Femora }{ }^{1} \\
F \text { content } \\
\quad(\mu g)\end{array}$ \\
\hline 1 & $\begin{array}{l}2800^{b} \\
410 \\
(5)\end{array}$ & 1700 & 1500 & \\
\hline 2 & $\begin{array}{l}2280^{b} \\
170 \\
(5)\end{array}$ & 2700 & 8400 & \\
\hline 3 & $\begin{array}{l}1410^{b} \\
200 \\
(5)\end{array}$ & 2400 & 7400 & \\
\hline 4 & $\begin{array}{l}1150 \mathrm{~b} \\
140 \\
(5)\end{array}$ & 1700 & 5300 & \\
\hline 5 & $\begin{array}{l}750^{b} \\
100 \\
(5)\end{array}$ & 1000 & 3100 & \\
\hline 6 & $\begin{array}{l}580^{b} \\
74 \\
(5)\end{array}$ & 440 & 1400 & \\
\hline
\end{tabular}


TABLE 37 (continued)

FLUORIDE EXCRETION AND FEMORAL FLUORIDE CONTENT OF RATS

FOLLOWING EXPOSURE TO $24 \mathrm{mg} \mathrm{F} / \mathrm{m}^{3}$ NaF FOR 6 HOURS

\begin{tabular}{|c|c|c|c|c|}
\hline Sacrifice day & $\begin{array}{l}\text { Urinary Ionicl } \\
\text { F- Excretion } \\
\text { ( } \mu \mathrm{g} / \text { day) }\end{array}$ & $\begin{array}{l}\text { Fecal Total }{ }^{2} \\
F \text { concentration } \\
(\mu \mathrm{g} / \mathrm{g})\end{array}$ & $\begin{array}{l}\text { Fecal Total } \\
\text { F excretion } \\
\quad(\mu \mathrm{g} / \text { day })\end{array}$ & $\begin{array}{l}\text { Femora }]^{1} \\
\mathrm{~F} \text { content } \\
\quad(\mu \mathrm{g})\end{array}$ \\
\hline 7 & $\begin{array}{l}450^{b} \\
58 \\
(5)\end{array}$ & 230 & 700 & \\
\hline 8 & $\begin{array}{c}430^{b} \\
48 \\
(5)\end{array}$ & 270 & 200 & $\begin{array}{l}936^{b} \\
104 \\
(5)\end{array}$ \\
\hline Control & $\begin{array}{l}70 \\
11 \\
(6)\end{array}$ & 58 & & $\begin{array}{r}237 \\
14 \\
(5)\end{array}$ \\
\hline
\end{tabular}

1 Values expressed as mean, S.E.M., (number of animals per group).

2 Feces excreted in each collection period were pooled prior to analysis. The fluoride concentration of each feces pool is reported.

3 Calculated assuming a mean fecal mass of $0.9 \mathrm{~g}$ for days 1 and 8 during which the rats were fasted and a mass of $3.1 \mathrm{~g}$ for days 2-7 during which the rats were fed.

b $p<0.01$ compared to control. 
control levels. The average daily fecal dry weights for fed and fasted rats during this experiment were 3.1 and 0.9 grams, respectively. These values were then used to estimate the daily fecal fluoride excretion. By comparing these data to the urinary fluoride excretion it is evident that more fluoride was excreted via the GI tract than the kidneys. Femoral fluoride concentrations in rats sacrificed 8 days after NaF exposure were 4 fold higher than control levels, the difference being significant at the $p<0.01$ level. If the cumulative fluoride absorption is estimated in the same manner as described in the HF retention experiment a value of $24 \mathrm{mg}$ fluoride is obtained for these NaF exposed rats. At a pulmonary ventilation rate of 0.15 liter/min it can be estimated that these rats inhaled only $1.3 \mathrm{mg}$ of fluoride. As in whole body HF exposed rats there appears to be a source of fluoride other than inhalation in these NaF exposed rats. This source again may be due to fluoride deposition on the fur.

The $\Delta F$ concentration in urine of rats exposed to $N a F$ are given in Table 38. Significant amounts of $\Delta F$ were not detected in urine of these animals. 
TABLE 38

$\triangle F$ CONCENTRATION IN URINE AFTER EXPOSURE TO $24 \mathrm{mg} \mathrm{F} / \mathrm{m}^{3} \mathrm{NaF}$ FOR 6 HOURS 1

\begin{tabular}{lccc} 
& \multicolumn{3}{c}{ Urine Fluoride Concentration } \\
$(\mu \mathrm{g} / \mathrm{ml})$ & \\
Collection period & Total & Ionic & $\Delta \mathrm{F}$ \\
$\frac{1}{2}-1$ & 151 & 157 & 6. \\
$1-2$ & 80 & 84 & -4. \\
$2-3$ & 34 & 36 & -2. \\
$3-4$ & 28 & 30 & -2. \\
$4-5$ & 25 & 27 & -2. \\
$5-6$ & 25 & 26 & -1. \\
$6-7$ & 18 & 19 & -1. \\
$7-8$ & 17 & 16 & 1. \\
Control day 1 & & & \\
Control day 2 & 4.7 & 4.0 & 0.7 \\
\end{tabular}

1 Urines were pooled prior to analysis. The fluoride concentrations determined in each pool are reported. Fluoride concentrations not corrected for cage wash water. 
II. Nose-only and Non-inhalation Exposures

The results of the HF retention experiment pointed out the necessity of developing another exposure system for investigations of HF toxicity. To this end a nose-only exposure unit was constructed. The experiments to be described in this section were undertaken to determine if a long-term pulmonary retention of fluoride occurred in rats exposed to HF via the nose-only route and to determine what fraction, if any, of inhaled $\mathrm{HF}$ is deposited in the upper respiratory tract. A number of supporting experiments were required, and are described here also. Since several of these experiments required the use of anaesthetized animals, rats were anaesthetized prior to HF exposure via the nose-only route. Nose-only exposures were of I hour duration. Rats were sacrificed at various times up to 4 days after exposure to HF.

A. Intravenous NaF Infusion

The results of the HF and NaF retention experiments indicated the possiblity that the lung contained binding sites for fluoride. Thus, the finding of lung fluoride concentrations in excess of plasma fluoride concentrations cannot be taken to indicate $\underline{\text { a }}$ priori, that HF entered the lung via the airways. To determine if fluoride binding in the lung could occur in the time course of the 
nose-only exposures rats were infused intravenously with $10.8 \mathrm{mg}$ $F / \min$ (as NaF) for 60 minutes and were sacrificed immediately or 6 hours after the termination of the infusion. Control rats were infused with $154 \mathrm{~mm} \mathrm{NaCl}$ at the same rate.

The pulmonary effects of intravenous fluoride infusion are given in Table 39. Rats sacrificed at 1 hour were sacrificed less than 1 minute after the end of the 1 hour infusion. Rats sacrificed at 7 hours were sacrificed 6 hours after the end of the 1 hour infusion. The lung weight to body weight ratio and the lung wet weight to dry weight ratio were similar in saline and NaF infused groups. Respiration frequency was determined in all groups during the infusions. No consistent effect of NaF infusion on respiration frequency occurred.

The effects of fluoride infusion on several renal parameters are shown in Table 40. No effect of fluoride infusion was evident on urine volume (bladder urine was removed in the 1 hour group), BUN or the kidney weight to body weight ratio in rats sacrificed at 1 hour. The kidney weight to body weight ratio, urine volume and urine specfic gravity were similar in control and fluoride infused rats sacrificed at 7 hours. The BUN in rats infused with fluoride and sacrificed in 7 hours were statistically higher than in control rats, however, the small increase may not be of physiologic significance. This is especially evident by comparison to the BUN in $\mathrm{NaCl}$ infused rats sacrificed at I hour.

The measured fluoride concentration in soft tissues of rats infused with $\mathrm{NaCl}$ or $\mathrm{NaF}$ are given in Table 4l. Total and ionic 


\section{TABLE 39}

\section{PULMONARY EFFECTS OF INTRAVENOUS INFUSION OF $10.8 \mu \mathrm{g} / \mathrm{min} \mathrm{NaF}$ FOR 1 HOUR $\mathrm{I}$}

Sacrifice time Body Wt. $\quad \frac{\text { Lung Wt. }}{\text { BodyWt. }} \quad \begin{aligned} & \text { Lung } \\ & \text { DryWt. }\end{aligned} \begin{array}{r}\text { Respiration2 } \\ \text { breaths/min }\end{array}$ $\frac{1 \text { hour }}{\mathrm{NaF}}$ 278

6

(6)

$\mathrm{NaCl}$

283

$(4)^{5}$

(5)

4.55

.03

(4)

4.75

.07

(5)

4.88

.02

(4)

$\frac{7 \text { hour }}{\mathrm{NaF}}$

(5)

4.39

.08

(5)

4.64

.06

(5)

$\mathrm{NaCl}$

300

(4)
5.00

.98

(4)
4.80

.05

(4)
1

(4)

(5)

74

(5)

$58 \mathrm{~b}$

61

7

70

(4)

1 Values expressed as mean, S.E.M. (numbers of animals per group) Exposed rats infused with $32 \mathrm{~mm} \mathrm{NaF}$ in $122 \mathrm{mM} \mathrm{NaCl}$, controls with $154 \mathrm{mM} \mathrm{NaC} 1$. Infusion started at time 0 .

2 Respirations were counted during infusion.

b $\quad \mathrm{p}<0.01$ compared to appropriate $\mathrm{NaCl}$ group. 
TABLE 40

RENAL EFFECTS OF INTRAVENOUS INFUSION OF $10.8 \mu \mathrm{g} \mathrm{F} / \mathrm{min} \mathrm{NaF}$ FOR 1 HOUR 1

\begin{tabular}{|c|c|c|c|c|}
\hline Sacrifice time & $\frac{\text { Kidney Wt. }}{\text { Body Wt. }}$ & $\begin{array}{l}\text { BUN } \\
(\mathrm{mg} \%)\end{array}$ & $\begin{array}{l}\text { Urine } \\
\text { Volume } \\
\text { (m1) }\end{array}$ & $\begin{array}{l}\text { Urine } \\
\text { specific gravity }\end{array}$ \\
\hline$\frac{1 \text { hour }}{\mathrm{NaF}}$ & $\begin{array}{r}7.32 \\
.24 \\
(5)\end{array}$ & $\begin{array}{r}13.4 \\
(59)\end{array}$ & $\begin{array}{r}0.54 \\
.10 \\
(5)\end{array}$ & \\
\hline $\mathrm{NaCl}$ & $\begin{array}{r}7.18 \\
.09 \\
(4)\end{array}$ & $\begin{array}{r}15.8 \\
1.3 \\
(4)\end{array}$ & $\begin{array}{r}0.44 \\
.05 \\
(4)\end{array}$ & \\
\hline$\frac{7 \text { hour }}{\mathrm{NaF}}$ & $\begin{array}{r}6.93 \\
.27 \\
(5)\end{array}$ & $\begin{array}{c}14.4^{a} \\
1.1 \\
(5)\end{array}$ & $\begin{array}{l}3.5 \\
(5)^{-6}\end{array}$ & $\begin{array}{l}1.035 \\
.004 \\
(5)\end{array}$ \\
\hline $\mathrm{NaCl}$ & $\begin{array}{r}6.93 \\
.13 \\
(4)\end{array}$ & $\begin{array}{r}11.5 \\
.2 \\
(3)\end{array}$ & $\begin{array}{r}3.6 \\
.6 \\
(4)\end{array}$ & $\begin{array}{l}1.038 \\
.004 \\
(4)\end{array}$ \\
\hline
\end{tabular}

1 Values expressed as mean, S.E.M., (number of animals per group). Exposed rats were infused with $32 \mathrm{mM} \mathrm{NaF}$ in $122 \mathrm{mM} \mathrm{NaCl}$, controls with $154 \mathrm{mM} \mathrm{NaCl}$. Infusion started at time 0 .

a $\quad \mathrm{p}<0.05$ compared to appropriate $\mathrm{NaCl}$ group. 
TABLE 41

MEASURED FLUORIDE CONCENTRATIONS IN SOFT TISSUES OF RATS INFUSED WITH $10.8 \mu \mathrm{g} \mathrm{F} / \mathrm{min} \mathrm{NaF}$ FOR 1 HOUR 1

\begin{tabular}{|c|c|c|c|c|c|c|c|}
\hline Sacrifice time & \multicolumn{2}{|c|}{$\begin{array}{l}\text { Lung } \\
(\mu \mathrm{g} / \mathrm{g}) \\
\text { Total Ionic }\end{array}$} & \multicolumn{2}{|c|}{$\begin{array}{l}\text { Plasma } \\
(\mu \mathrm{g} / \mathrm{ml})\end{array}$} & \multicolumn{2}{|c|}{$\begin{array}{l}\text { Kidney } \\
(\mu \mathrm{g} / \mathrm{g})\end{array}$} & $\begin{array}{c}\text { Trachea2 } \\
\text { ( } \mu \mathrm{g} / \mathrm{g}) \\
\text { Total }\end{array}$ \\
\hline \multicolumn{8}{|l|}{1 hour } \\
\hline $\mathrm{NaF}$ & $\begin{array}{l}1.1 \\
.0 \\
(4)\end{array}$ & $\begin{array}{l}1.05^{b} \\
.06 \\
(4)\end{array}$ & $\begin{array}{r}2.69 \\
.11 \\
(5)\end{array}$ & $\begin{array}{l}2.67^{b} \\
.07 \\
(5)\end{array}$ & $\begin{array}{r}4.1 \\
.3 \\
(5)\end{array}$ & $\begin{array}{l}4.15^{b} \\
.56 \\
(5)\end{array}$ & 15. \\
\hline $\mathrm{NaCl}^{2}$ & 0.0 & $\begin{array}{r}0.06 \\
.01 \\
(4)\end{array}$ & 0.10 & $\begin{array}{l}0.044 \\
.002 \\
(4)\end{array}$ & 0.0 & $\begin{array}{r}0.10 \\
.01 \\
(4)\end{array}$ & 15. \\
\hline \multicolumn{8}{|l|}{7 hour } \\
\hline $\mathrm{NaF}$ & $\begin{array}{r}0.7 \\
.1 \\
(5)\end{array}$ & $\begin{array}{r}0.06 \\
.01 \\
(5)\end{array}$ & $\begin{array}{r}0.42 \\
.03 \\
(5)\end{array}$ & $\begin{array}{c}0.167 \mathrm{a} \\
.005 \\
(5)\end{array}$ & $\begin{array}{r}0.7 \\
.2 \\
(5)\end{array}$ & $\begin{array}{r}0.13 \\
.02 \\
(5)\end{array}$ & 19. \\
\hline $\mathrm{NaCl}$ & $\begin{array}{r}0.9 \\
.1 \\
(4)\end{array}$ & $\begin{array}{r}0.07 \\
.01 \\
(4)\end{array}$ & $\begin{array}{r}0.32 \\
.06 \\
(3)\end{array}$ & $\begin{array}{l}0.138 \\
.011 \\
(4)\end{array}$ & $\begin{array}{r}0.8 \\
.2 \\
(4)\end{array}$ & $\begin{array}{r}0.11 \\
.02 \\
(4)\end{array}$ & 23. \\
\hline
\end{tabular}

1 Values expressed as mean, S.E.M. (number of animals per group). Exposed rats were infused with $32 \mathrm{mM} \mathrm{NaF}$ in $122 \mathrm{mN} \mathrm{NaCl}$, controls with $154 \mathrm{mM} \mathrm{NaCl}$. Infusion started at time 0 .

2 Tissues were pooled by group prior to determination of total fluoride concentration. The fluoride concentration determined in each tissue pool is given.

a $\quad \mathrm{p}<0.05$ compared to appropriate $\mathrm{NaCl}$ group.

b $\quad \mathrm{p}<0.01$ compared to appropriate $\mathrm{NaCl}$ group. 
fluoride concentrations in lung, plasma and kidney of rats sacrificed immediately after the infusion ( 1 hour group) were markedly elevated over control levels. In these fluoride infused rats the lung ionic fluoride concentration averaged 398 of the plasma ionic fluoride concentration. Total and ionic fluoride concentrations in the lungs and kidneys of rats sacrificed at 7 hours were similar to control levels. Plasma ionic fluoride concentrations in fluoride infused rats sacrificed at this time were significantly higher than control levels. The plasma ionic fluoride concentration in the $\mathrm{NaCl}$ infused control group sacrificed at 7 hours was 3 fold higher than in NaCl control rats sacrificed at $I$ hour. The reasons for this are unclear. The tracheas of control and fluoride infused rats were pooled by group and ashed for determination of total fluoride concentration. No increase in tracheal fluoride content in fluoride infused rats was evident. The tracheas weighed an average of $0.1 \mathrm{gram}$ each. The $\Delta F$ concentrations in soft tissues of rats infused with NaF are given in Table 42. At neither sacrifice time were the $\Delta F$ concentrations of soft tissues of rats infused with fluoride higher than in control rats.

The urinary fluoride excretion, fecal fluoride concentration and femoral fluoride content of $\mathrm{NaCl}$ and $\mathrm{NaF}$ infused rats are given in Table 43. The ionic fluoride present in the bladder urine of rats sacrificed at $I$ hour and excreted during the 7 hour experimental period by rats sacrificed at that time were both significantly higher than control levels. A mean of $5.6 \%$ of the 
$\triangle F$ CONCENTRATIONS IN SOFT TISSUES OF RATS INFUSED INTRAVENOUSLY WITH $10.8 \mathrm{ug} \mathrm{F} / \mathrm{min} \mathrm{NaF}^{1}$

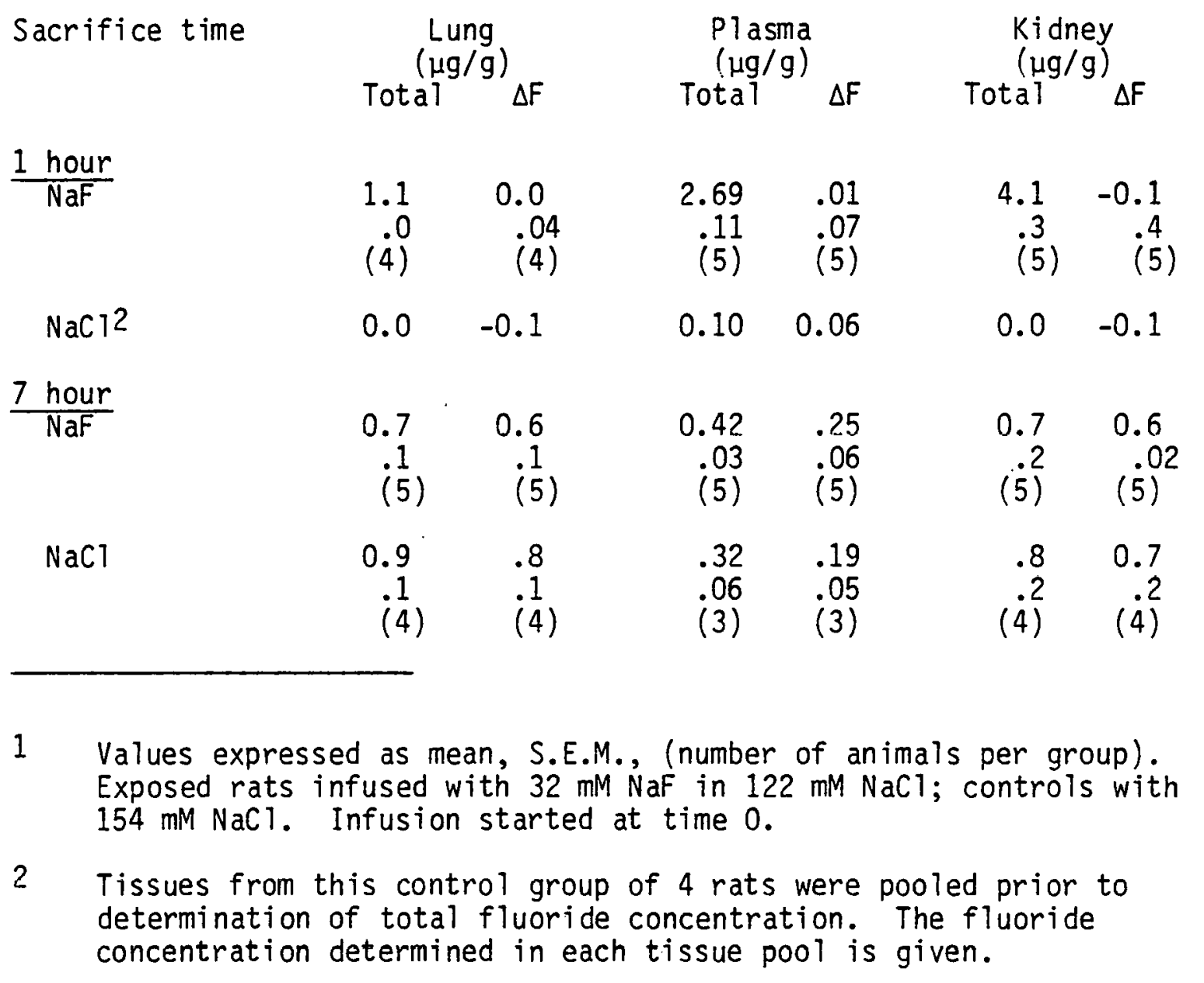


URINARY IONIC FLUORIDE EXCRETION, FECAL TOTAL FLUORIDE CONCENTRATION AND FEMORAL FLUORIDE CONTENT IN RATS INTRAVENOUSLY INFUSED WITH $10.8 \mu \mathrm{g} / \mathrm{min} \mathrm{NaF}$ FOR 1 HOUR

$\begin{array}{cccr}\text { Sacrifice time } & \begin{array}{c}\text { Urine Ionic F- } \\ (\mu \mathrm{g} / \text { period })\end{array} & \begin{array}{c}\text { Fecal Total } \mathrm{F}^{2} \\ (\mu \mathrm{g} / \mathrm{g})\end{array} & \begin{array}{c}\text { Femoral F } \\ (\mu \mathrm{g} / \mathrm{g})\end{array} \\ \frac{1 \text { hour }}{\mathrm{NaF}} & \begin{array}{c}39.2^{\mathrm{b}} \\ 5.8\end{array} & 126 & 195 \\ & (5)^{.} & & 17 \\ \mathrm{NaCl} & 3.0 & 117 & (5) \\ & (4)^{3} & & 183 \\ \frac{7 \text { hour }}{\mathrm{NaF}} & & & 4 \\ & 145 . \mathrm{b} & 115 & (5) \\ & 19 & & 222 \\ \mathrm{NaCl} & (5) & & 15 \\ & 19.9 & 122 & (4) \\ & 1.6 & & 238 \\ & (4) & & (39)\end{array}$

1 Values expressed as mean, S.E.M. (number of animals per group). Exposed rats infused with $32 \mathrm{mM} \mathrm{NaF}$ in $122 \mathrm{mM} \mathrm{NaCl}$; controls with $154 \mathrm{mM} \mathrm{NaCl}$. Infusion started at time 0 . Urine collected from time 0 until time of sacrifice

2 The last few fecal pellets in the intestinal tract of each rat were removed and pooled. The total fluoride concentration in each fecal pool is given.

b $\quad \mathrm{p}<0.01$ compared to appropriate $\mathrm{NaCl}$ group 
infused fluoride dose was present in the urine of rats sacrificed immediately after the infusion ( 1 hour group). A mean of 198 of the infused fluoride dose was excreted in the urine during the entire 7 hour experimental period. The urines excreted during the 7 hour experimental period by control and fluoride infused rats were pooled by group ashed for determination of total fluoride concentration. $\Delta F$ was not detected in either of these urine pools.

B. HF Retention - Normal F Diet

Anaesthetized male Long Evans rats were exposed to $75 \mathrm{mg} \mathrm{F} / \mathrm{m}^{3}$ HF for 1 hour in the nose-only exposure unit. Anaesthetized male Long Evans rats exposed to room air for I hour in a similar chamber served as controls. Rats were housed individually in metabolism cages for the 96 hour postexposure period. All rats were sacrificed 96 hours after the start of exposure.

The pulmonary effects of nose-only exposure to $75 \mathrm{mg} \mathrm{F} / \mathrm{m}^{3} \mathrm{HF}$ in one hour are given in Table 44. Body weight, lung weight to body weight ratio and lung wet weight to dry weight ratio were measured in rats at sacrifice and were simillar in both control and exposed groups. Respirations were counted during exposure and were also similar in control and exposed groups.

The effects of nose-only exposure to $75 \mathrm{mg} \mathrm{F} / \mathrm{m}^{3}$ on several renal parameters are given in Table 45 . The BUN and kidney weight to body weight ratio of rats sacrificed 4 days after exposure were unaffected by HF. Urines were collected from each animal from times $0-7,7-24,24-48,48-72$ and 72-96 hours. In no collection 


\section{PULMONARY EFFECTS OF NOSE-ONLY EXPOSURE}

TO $75 \mathrm{mg} \mathrm{F} / \mathrm{um}^{3}$ HF FOR 1 HOUR 1

$$
\begin{array}{cccc}
\text { Body Wt. } & \text { Lung Wt. } & \text { Lung } & \\
(\mathrm{g}) & \begin{array}{c}
\text { Wody Wt. } \\
\text { Boty }
\end{array} & \text { Dry Wt. } & \begin{array}{c}
\text { Respirations2 } \\
\text { (breaths/min) }
\end{array}
\end{array}
$$

Exposed

253

(5)

Control

257

(5)
4.59

.41

(5)

4.54

.18

(5)
4.76

.02

(5)

4.69

.03

(5)
72

4

(4)

69

4

(4)

1 Values expressed as mean, S.E.M., (number of animals per group). HF generated by compressed gas technique. Rats were sacrificed 96 hours after the start of exposure.

2 Respirations were counted during exposure. 
TABLE 45

RENAL EFFECTS OF NOSE-ONLY EXPOSURE TO $75 \mathrm{mg} \mathrm{F} / \mathrm{m}^{3} \mathrm{HF}$ FOR 1 HOUR 1

\begin{tabular}{|c|c|c|c|c|c|c|c|c|c|c|}
\hline \multirow[t]{2}{*}{$\begin{array}{c}\text { Collection } \\
\text { Period }\end{array}$} & \multicolumn{2}{|c|}{$\begin{array}{l}\text { Urine Volume } \\
\text { (ml) }\end{array}$} & \multirow{2}{*}{$\begin{array}{l}\text { Urine } \\
\text { Exp. }\end{array}$} & \multirow{2}{*}{$\begin{array}{l}\text { sp. gr. } \\
\text { Cont. }\end{array}$} & \multicolumn{2}{|c|}{$\begin{array}{l}\text { Urine Protein } \\
\text { (mg/period) }\end{array}$} & \multicolumn{2}{|c|}{$\begin{array}{c}\text { BUN } \\
(\mathrm{mg} \%)\end{array}$} & \multicolumn{2}{|c|}{$\frac{\text { Kidney } W t}{\text { Body } W t}$} \\
\hline & Exp. & Cont. & & & Exp. & Cont. & Exp. & Cont. & Exp. & Cont. \\
\hline $0-7 \mathrm{hr}$. & $\begin{array}{l}1.3 \\
.2 \\
(5)\end{array}$ & $\begin{array}{r}1.0 \\
.3 \\
(5)\end{array}$ & $\begin{array}{l}1.086 \\
.016 \\
(5)\end{array}$ & $\begin{array}{l}1.167 \\
.052 \\
(5)\end{array}$ & $\begin{array}{c}22 \\
3 \\
(5)\end{array}$ & $\begin{array}{c}19 \\
3 \\
(5)\end{array}$ & & & & \\
\hline $7-24 \mathrm{hr}$. & $\begin{array}{l}7.0 \\
3.1 \\
(5)\end{array}$ & $\begin{array}{l}5.6 \\
1.2 \\
(5)\end{array}$ & $\begin{array}{l}1.085 \\
.017 \\
(5)\end{array}$ & $\begin{array}{c}1.048 \\
.009 \\
(5)\end{array}$ & $\begin{array}{c}52 \\
7 \\
(5)\end{array}$ & $\begin{array}{c}40 \\
5 \\
(5)\end{array}$ & & & & \\
\hline $24-48 \mathrm{hr}$. & $\begin{array}{l}8.2 \\
1.5 \\
(5)\end{array}$ & $\begin{array}{l}6.4 \\
1.2 \\
(5)\end{array}$ & $\begin{array}{l}1.060 \\
.016 \\
(5)\end{array}$ & $\begin{array}{l}1.070 \\
.009 \\
(5)\end{array}$ & $\begin{array}{l}70 \\
13 \\
(5)\end{array}$ & $\begin{array}{c}66 \\
6 \\
(5)\end{array}$ & & & & \\
\hline $48-72 \mathrm{hr}$. & $\begin{array}{l}8.2 \\
2.4 \\
(5)\end{array}$ & $\begin{array}{l}7.4 \\
1.4 \\
(5)\end{array}$ & $\begin{array}{l}1.072 \\
.016 \\
(5)\end{array}$ & $\begin{array}{c}1.073 \\
.013 \\
(5)\end{array}$ & $\begin{array}{l}71 \\
12 \\
(5)\end{array}$ & $\begin{array}{l}83 \\
10 \\
(5)\end{array}$ & & & & \\
\hline $72-96 \mathrm{hr}$. & $\begin{array}{l}12 . \\
1.9 \\
(5)\end{array}$ & $\begin{array}{r}14 \\
2.4 \\
(5)\end{array}$ & $\begin{array}{l}1.031 \\
.009 \\
(5)\end{array}$ & $\begin{array}{l}1.028 \\
.006 \\
(5)\end{array}$ & $\begin{array}{c}59 \\
6 \\
(5)\end{array}$ & $\begin{array}{c}82 \\
9 \\
(5)\end{array}$ & $\begin{array}{r}16 \\
1 \\
(4)\end{array}$ & $\begin{array}{c}16 \\
1 \\
(4)\end{array}$ & $\begin{array}{c}7.33 \\
.39 \\
(5)\end{array}$ & $\begin{array}{l}6.98 \\
.22 \\
(5)\end{array}$ \\
\hline
\end{tabular}

1 Values expressed as mean, S.E.M., (number of animals per group). HF generated by compressed gas system. Exposure started at time zero; rats sacrificed at 96 hours. 
period was the urine specific gravity or protein content significantly altered from control levels by HF inhalation. The volume of urine excreted by the HF exposed rats tended to be higher than control rats, but at no time were the two groups significantly different. Water and food consumptions during the 4 day postexposure period were also similar in control and exposed animals.

The measured fluoride concentrations in soft tissues of rats sacrificed 4 days after nose-only exposure to $75 \mathrm{mg} \mathrm{F} / \mathrm{m}^{3} \mathrm{HF}$ are given in Table 46. Total and ionic fluoride concentrations in lung, plasma and kidney were all similar to control levels. These results are in marked contrast to rats sacrificed 4 days after whole-body exposure to HF in which the fluoride concentrations in lung, plasma and kidney were significantly elevated over control levels at this time.

The $\Delta F$ concentrations in soft tissues of rats sacrificed 4 days after nose-only exposure to $75 \mathrm{mg} \mathrm{F} / \mathrm{m}^{3} \mathrm{HF}$ are given in Table 47. $\Delta F$ appeared to be present in lung, plasma and kidney of control and exposed rats, The $\Delta F$ concentrations in the tissues of exposed rats, however, were no higher than in control rats. Urinary fluoride excretion was significantly elevated 0-7 hours and 7-24 hours after the start of $H F$ exposure (Table 48). The urinary fluoride excretion during the 24-48 hour period after exposure to $\mathrm{HF}$ averaged 1318 of control levels but the two groups were not significantly different. 
TABLE 46

MEASURED FLUORIDE CONCENTRATIONS IN SOFT TISSUES OF RATS SACR IFICED 96 HOURS AFTER THE START OF NOSE-ONLY EXPOSURE TO $75 \mathrm{mg} \mathrm{F} / \mathrm{m}^{3}$ HF FOR 1 HOUR 1

\begin{tabular}{|c|c|c|c|c|c|c|c|}
\hline & $\begin{array}{r}\quad l \\
\text { Total }\end{array}$ & Ionic & $\begin{array}{r}\text { Pla } \\
(\mu g \\
\text { Total }\end{array}$ & $\begin{array}{l}\text { na } \\
\text { Ionic }\end{array}$ & $\begin{array}{r}K \\
\text { Tota }\end{array}$ & $\begin{array}{l}y \\
\text { Ionic }\end{array}$ & $\begin{array}{c}\text { Trach } \\
(\mu \mathrm{g} / \\
\text { Tota }\end{array}$ \\
\hline Exposed & $\begin{array}{l}0.3 \\
(\dot{5})\end{array}$ & $\begin{array}{r}0.10 \\
.01 \\
(5)\end{array}$ & $\begin{array}{r}0.11 \\
.06 \\
(3)\end{array}$ & $\begin{array}{c}0.037 \\
.006 \\
(5)\end{array}$ & $\begin{array}{l}0.3 \\
.1 \\
(5)\end{array}$ & $\begin{array}{r}0.12 \\
.01 \\
(5)\end{array}$ & $\begin{array}{c}19 \\
2 \\
(5)\end{array}$ \\
\hline Control & $\begin{array}{l}0.3 \\
(\dot{5})\end{array}$ & $\begin{array}{r}0.09 \\
.01 \\
(5)\end{array}$ & $\begin{array}{r}0.07 \\
.01 \\
(4)\end{array}$ & $\begin{array}{c}0.049 \\
.004 \\
(5)\end{array}$ & $\begin{array}{l}0.3 \\
\dot{1} \\
(5)\end{array}$ & $\begin{array}{r}0.12 \\
.01 \\
(5)\end{array}$ & $\begin{array}{c}19 \\
2 \\
(5)\end{array}$ \\
\hline
\end{tabular}

1 Values expressed as mean, S.E.M., (number of animals per group.) HF generated by compressed gas technique. 
TABLE 47

$\triangle F$ CONCENTRATIONS IN SOFT TISSUES OF RATS SACRIFICED

96 HOURS AFTER THE START OF NOSE-ONLY EXPOSURE TO $75 \mathrm{mg} \mathrm{F} / \mathrm{m}^{3} \mathrm{HF}$ FOR 1 HOUR 1

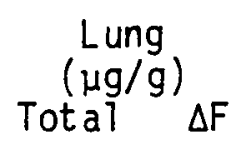

Exposed

$0.3 \quad 0.2$

$(\dot{5}) \quad(\dot{1})$

Control

$0.3 \quad 0.2$

$(\dot{5}) \quad(\dot{5})$ $\underset{\text { Total }}{(\mu \mathrm{g} / \mathrm{ml})} \Delta \mathrm{F}$

$0.11 \quad 0.07$

$.06 \quad .07$

(3) (3)

0.07

.01

(4)

0.02

.01

(4)
Kidney

$(\mu g / g)$

1 Values expressed as mean, S.E.M., (number of animals per group). HF generated by compressed gas system. 
TABLE 48

\begin{tabular}{|c|c|c|c|c|c|c|}
\hline \multirow{3}{*}{$\begin{array}{l}\text { Collection } \\
\text { period } \\
0-7 \text { hrs. }\end{array}$} & \multicolumn{2}{|c|}{$\begin{array}{l}\text { Urine Ionic F- } \\
(\mu \mathrm{g} / \text { period })\end{array}$} & \multicolumn{2}{|c|}{$\begin{array}{c}\text { Fecal Total } F^{2} \\
(\mu \mathrm{g} / \mathrm{g})\end{array}$} & \multicolumn{2}{|c|}{$\underset{(\mu g)}{\text { Femoral }} F$} \\
\hline & $\operatorname{con} \tau$ & Exp. & Cont. & Exp. & & Exp. \\
\hline & $\begin{array}{r}18 \\
2 \\
(5)\end{array}$ & $\begin{array}{l}64 b \\
10 \\
(5)\end{array}$ & & & & \\
\hline 7-24 hrs. & $\begin{array}{r}33 \\
3 \\
(5)\end{array}$ & $\begin{array}{l}78 \mathrm{~b} \\
14 \\
(5)\end{array}$ & 81 & 121 & & \\
\hline $24-48 \mathrm{hrs}$. & $\begin{array}{r}59 \\
5 \\
(5)\end{array}$ & $\begin{array}{r}77 \\
17 \\
(5)\end{array}$ & 97 & 107 & & \\
\hline 48-72 hrs. & $\begin{array}{r}71 \\
9 \\
(5)\end{array}$ & $\begin{array}{r}66 \\
9 \\
(5)\end{array}$ & & 102 & & \\
\hline 72-96 hrs. & $\begin{array}{r}62 \\
7 \\
(5)\end{array}$ & $\begin{array}{r}48 \\
8 \\
(5)\end{array}$ & 138 & 72 & $\begin{array}{r}162 \\
10 \\
(5)\end{array}$ & $\begin{array}{c}192^{a} \\
8 \\
(5)^{8}\end{array}$ \\
\hline
\end{tabular}

1 Values expressed as mean, S.E.M., (number of animals per group). HF generated by compressed gas technique. Exposure started at time 0 ; rats sacrificed at 96 hours.

2 Feces pooled by group. The fluoride concentration determined in each pool is given.

a $\quad p<0.05$ compared to control.

b $\quad p<0.01$ compared to control. 
The urinary fluoride excretion in control animals averaged 51 $\mu \mathrm{g}$ from 0-24 hours (18 $\mathrm{\mu g}$ from 0-7 hours, $33 \mu \mathrm{g} 7-24$ hours) $59 \mu \mathrm{g}$ from 24-48 hours, $71 \mu \mathrm{g}$ from $48-72$ hours and $62 \mu \mathrm{g}$ from 72-96 hours after the control exposure. During the entire 96 hour postexposure period control animals excreted $244 \pm 24$ (5) $\mu \mathrm{g}$ $[m e a n \pm$ S.E.(number of animals)]. HF exposed rats excreted $334 \pm$ 32 (5) $\mu \mathrm{g}$ during the 96 hour postexposure period. These two values are not significantly different. Thus, while this exposure regimen resulted in an increase in urinary fluoride excretion, the increase was not very large compared to the amount of fluoride excreted by control rats.

The fecal concentration and femoral fluoride content of rats exposed to $75 \mathrm{mg} \mathrm{F} / \mathrm{m}^{3} \mathrm{FF}$ for 1 hour are also given in Table 48 . The fluoride concentration in feces of exposed animals did not appear to be higher than in control rat feces. The femoral fluoride content in rats sacrificed 4 days after exposure to HF was significantly higher than control levels.

Urine samples were pooled by group and ashed for determination of total fluoridc concentration. As is showin in Table 49, significant amounts of $\Delta F$ were not detected in the urine of control or HF exposed rats.

The excess urinary fluoride excretion can be used to estimate the amount of fluoride absorbed. In an experiment to be described below, 228 of an administered fluoride dose was excreted in the urine. Thus, division of the excess uxinary fluoride excretion due to $\mathrm{HF}$ by $22 \%$ gives an estimate of the absorbed dose of fluoride in 
TABLE 49

$\triangle F$ CONCENTRATION IN URINE AFTER NOSE-ONLY EXPOSURE TO $75 \mathrm{mg} \mathrm{Fm} / \mathrm{m}^{3}$ HF FOR I HOUR 1

Collection period

Urine fluoride concentration $(\mu \mathrm{g} / \mathrm{ml})$

Total Ionic $\Delta \mathrm{F}$

Exposed

\begin{tabular}{|c|c|c|}
\hline $\begin{array}{rl}0-7 & \mathrm{hr} \\
7-24 & \mathrm{hr} \\
24-48 \mathrm{hr} \\
48-72 \mathrm{hr} \\
72-96 \mathrm{hr}\end{array}$ & $\begin{array}{l}6.4 \\
5.5 \\
4.4 \\
4.1 \\
2.3\end{array}$ & $\begin{array}{l}6.6 \\
5.4 \\
4.8 \\
4.2 \\
2.6\end{array}$ \\
\hline
\end{tabular}

Control

$\begin{array}{rlrr}0-7 \mathrm{hr} & 2.0 & 2.0 & 0.0 \\ 7-24 \mathrm{hr} & 2.8 & 2.6 & .2 \\ 24-48 \mathrm{hr} & 4.0 & 4.2 & -.2 \\ 48-72 \mathrm{hr} & 4.1 & 4.6 & -.5 \\ 72-96 \mathrm{hr} & 2.8 & 2.9 & -.1\end{array}$

1 Urines were pooled prior to analysis. The fluoride concentration determined in each pool is given. Fluoride concentration is not corrected for cage wash water. HF gener ated by comcompressed gas technique. Exposure started at time 0 . 
these rats. Since the excess urinary fluoride excretion in exposed animals 24-48 hours after exposure may have been due to HF exposure, the excess urinary fluoride excretion from time 0-48 hours was used for this estimation. During this time period, HF exposed rats excreted an excess of $108 \pm 20 \mu \mathrm{g}$ of fluoride. The standard error for the excess fluoride excretion was calculated as the square root of the sum of the squares of the standard errors for the control and exposed group. From this value it is estimated that $\mathrm{HF}$ exposed rats absorbed an excess of $491 \pm 91 \mathrm{\mu g}$ of fluoride. At a pulmonary ventilation of $100 \mathrm{cc} / \mathrm{min}$ it can be estimated that HF exposed rats inhale $450 \mathrm{\mu g}$ of fluoride. These estimates are in good agreement suggesting that the excess source of fluoride found previously in whole body exposed rats is not present in nose-only exposed rats. If the excess skeletal fluoride deposition is estimated assuming the femur comprises $4.65 \%$ of the skeleton and $78 \%$ of an acute dose of fluoride is deposited in this site $(100 \%$ - $22 \%$ urinary excretion $=78 \%)$ a value of $877 \pm 330$ (mean \pm S.E.M., S.E.M. estimated as for excess urinary fluoride excretion) ic obtained. This value is not stat1stically different for the value obtained using the urinary fluoride excretion. The large standard error of the mean for this estimate based on femoral fluoride deposition when only small amounts of fluoride are deposited due to HF exposure compared to the amount that is already present suggests that measurement of the urinary fluoride excretion would give a more reliable estimate of the absorbed fluoride dose. 
C. Fluoride Depletion Experiment

In the previous experiment it was evident that the fluoride excretion in urine and feces of control rats was sufficiently high to make interpretation of data for HF exposed rats difficult. It was, therefore, decided to maintain rats on low fluoride diet and distilled water. In this experiment the rate at which the urinary fluoride excretion, fecal fluoride excretion, and soft tissue fluoride concentration decreased was investigated when rats were placed on low fluoride diet and later given NaF by intratracheal injection.

Sixteen male Long Evans rats, housed individually in metabolism cages, were fed normal diet (32 $\mathrm{\mu g} / \mathrm{g} \mathrm{F}$ content) and tap water ( $\mathrm{l}$ $\mu \mathrm{g} / \mathrm{ml}$ F). After 3 days, 4 rats were sacrificed and the remaining 12 rats were given low fluoride diet $(0.7 \mu \mathrm{g} / \mathrm{g} F$ content) and distilled water $(<0.01 \mu \mathrm{g} / \mathrm{ml} \mathrm{F})$. Timing for the experiment began on the beginning of this day (time 0 ). On day 6 , a group of 4 rats was sacrificed. On the morning of day 12, 5 rats were instilled intratracheally with $200 \mu \mathrm{g} F$ as $\mathrm{NaF}$ and 3 rats were sham operated and served as controls. Two rats died during NaF installation, presumably due to drowning. These instilled and control rats were sacrificed 4 days later, at the end of the 15 th day on low fluoride diet. Rats were assigned to sacrifice group (day 0 , day 6 , day 15 control, day 15 instilled) on a random basis. Urine and feces were collected every day. Fecal samples collected on days -2 through to +11 were pooled by group prior to analysis. Feces excreted on days 12, 13, 14, and 15 were not pooled. 
The body weight and organ to body weight ratios in rats sacrificed at various times during the fluoride depletion experiment are given in Table 50. All rats were weighed on days $-3,0$ and 12. All rats gained weight during the experiment. Water and food consumption were similar in rats consuming normal $F$ diet and tap water and rats consuming low $F$ diet and distilled water. Consumption of low $\mathrm{F}$ diet averaged $18 \mathrm{~g} /$ day. The kidney to body weight ratio tended to be lower in rats fed low $F$ diet than in rats fed normal $F$ diet. This difference was significant in rats instilled with NaF and sacrificed on day 15. The lung weight to body weight ratio in rats fed low $F$ diet was also lower than in rats fed normal $F$ diet. This ratio was significantly lower than on day 0 in rats sacrificed on the 6 th and 15 th day of low $F$ diet feeding.

The volume of urine excreted per day and the urine specific gravity were unaffected by low F diet. The BUN was similar in rats fed low $F$ diet and normal diet. Urinary protein excretion was not measured.

The measured lluuride concentrations in soft tissues of rats fed low $F$ diet for varying periods of time are shown in Table 51. The total fluoride concentrations in lung, plasma and kidney of animals fed normal diet (day 0 group) are at the limit of sensitivity of the total fluoride analytical method, therefore, no decrease in these concentrations would be detected analytically. The ionic fluoride concentration in the lungs of animals sacrificed on day 0 (normal diet) are also at the limit of sensitivity. The 
TABLE 50

PULMONARY AND RENAL EFFECTS OF FLUORIDE DEPLETION 1

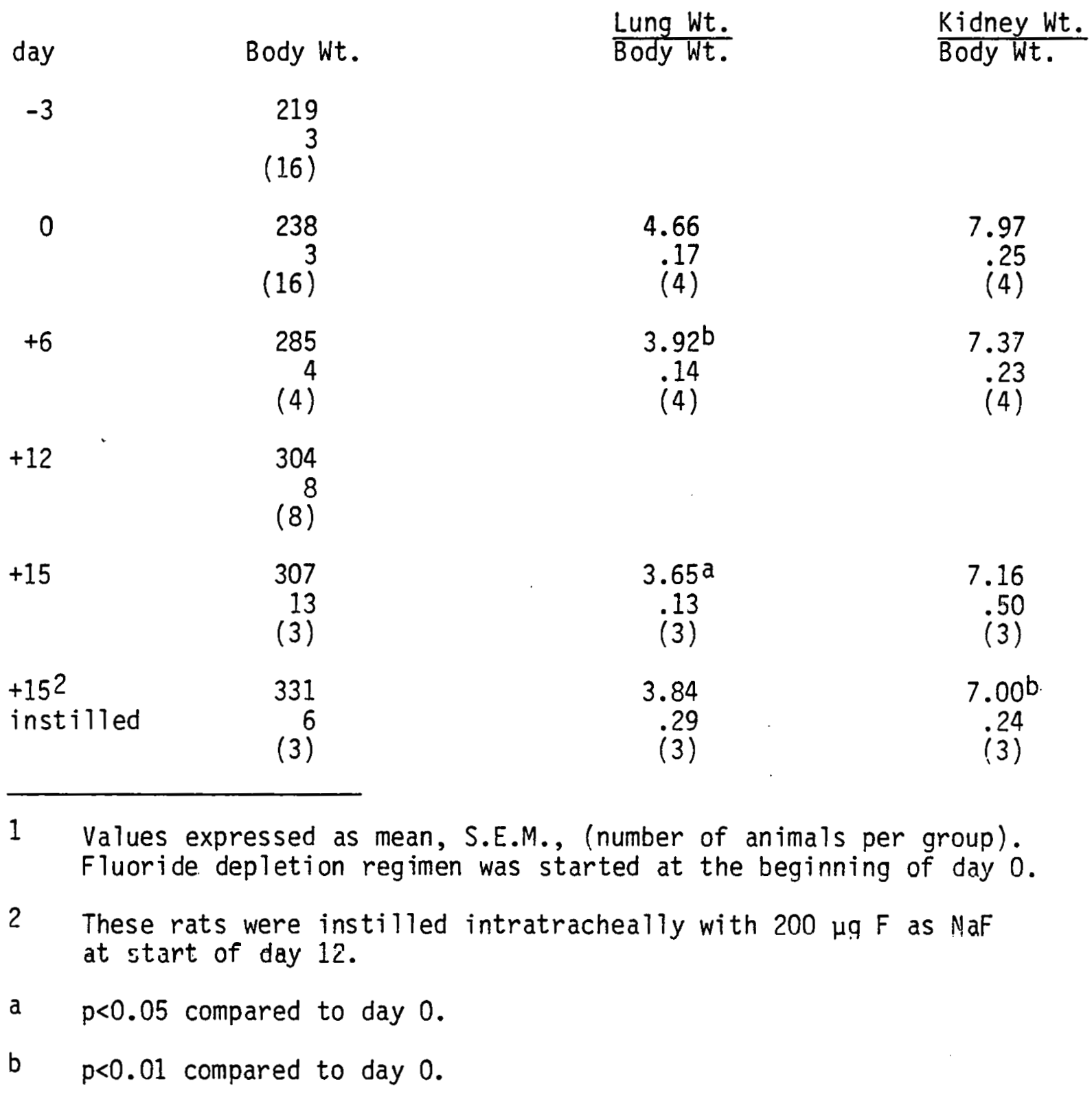


TABLE 51

MEASURED FLUORIDE CONCENTRATIONS IN SOFT TISSUES

OF RATS DURING FLUORIDE DEPLETION 1

\section{Sacrifice}

time

Day 0

Day 6

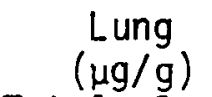

Total Ionic

(4)

$0.5 \quad 0.03$

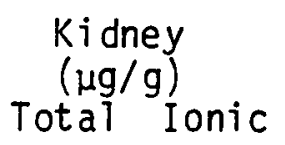

0.2<smiles>[C]#[Al]</smiles>

(4)

(4) (4)

$.3 \quad .02$

(4)
$0.02 \quad 0.052$

$.01 \quad .007$

(4) (4)
$0.2 \quad 0.08$

$.1 \quad .02$

(4)

(4)

0.13

.02

(4)

$0.1 \quad 0.04$

$.1 \quad .02$

(3)

(3)

$0.0 \quad 0.03$

$.0 \quad .00$

(3)

Trachea

$(\mu \mathrm{g} / \mathrm{g})$

Total

4.

1 (4)

(4)

7.

1.

(4)

Day 15
0.3
.0
(3)
(3)
(3)
(3)

$\begin{array}{rrrr}0.4 & 0.02 & 0.06 & 0.007 \\ (3) & .01 & .01 & .000 \\ (3) & (3) & (3)\end{array}$

$\begin{array}{rrrr}0.4 & 0.02 & 0.06 & 0.007 \\ (3) & .01 & .01 & .000 \\ (3) & (3) & (3)\end{array}$

(3)

Oay $15^{2}$

(3)

1 Values expressed as

Fluoride depletion regimen was.M., (number of animals per group).

2 These rats were instilled intratracheally with $200 \mu \mathrm{F}$ as $\mathrm{NaF}$ at the start of day 12 . 
ionic fluoride concentration in the kidneys of rats decreased with increasing time on low $\mathrm{F}$ diet. Plasma ionic fluoride concentration was significantly lower in rats sacrificed after 15 days on low $F$ diet than in rats fed normal diet, but no decrease in plasma ionic F concentration was evident in rats sacrificed after only 6 days on low $F$ diet. Tracheal fluoride concentration increased with time, even though rats were fed low F diet. By comparing the fluoride concentrations in soft tissues of rats sacrificed 4 days after intratracheal instillation of $200 \mu \mathrm{g} \mathrm{F}$ (as NaF) to the day 15 sham-operated rats it is apparent that detectable amounts of fluoride are not retained in the lung, plasma or kidney of rats so treated with fluoride.

The $\Delta F$ concentrations in soft tissues of rats fed low $F$ diet for varying periods of time are shown in Table 52. The $\Delta F$ concentrations in all tissues were so low that no real comparisons can be made.

The daily urinary ionic fluoride excretion in rats fed low fluoride diet is shown in Figure 22. As can be seen the mean urinary fluoridc exeretion decreased throughout the entire 15 day experimental period. On the 15th day of low F diet feeding rats excreted an average of 10. \pm 2 . (3) $\mu \mathrm{g} \mathrm{F[mean} \pm$ S.E. $(n)]$. The fluoride intake during this day averaged $12 \mu \mathrm{g}$ indicating these rats were in zero or positive fluoride balance. The logarithm of the daily fluoride excretion is plotted against experimental day in Figure 23. The fluoride excretion from day 2-15 appeared to fit a single line the slope of which indicated that under these 
TABLE 52

$\triangle F$ CONCENTRATIONS IN SOFT TISSUES OF RATS DURING

FLUORIDE DEPLETION 1

\section{Sacrifice \\ time}

Day 0

Day 6

Day 15

Day $15^{2}$

Instilled

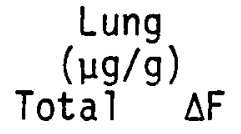

$0.6 \quad 0.6$

(4) $\left(\dot{4}^{1}\right)$

$0.5 \quad 0.4$

$.0 \quad .0$

(4) (4)

$0.3 \quad 0.3$

$.0 \quad .0$

(3) (3)

$0.4 \quad 0.3$

(3) (3)

(3)
Plasma
$(\mu \mathrm{g} / \mathrm{ml})$
$\operatorname{Total} \Delta \mathrm{F}$

$\begin{array}{lll}0.01 & -0.04\end{array}$

(4) 0101

$0.02-0.04$

$.01 \quad .00$

(4) (4)

$0.03 \quad 0.02$
.01

$.01 \quad .01$

(3) (3)

$0.06 \quad 0.05$

$.01 \quad .01$

(3)

(3)
Kidney

$(\mu \mathrm{g} / \mathrm{g})$

Total $\Delta F$

0.20 .0

$.1 \quad .1$

(4)

(4)

0.20 .1

$.1 \quad .1$

(4) (4)

$0.1 \quad 0.0$

$.1 \quad .0$

(3) (3)

$0.0 \quad 0.0$

$0.0 \quad 0.0$

$.0 \quad .0$

(3) (3)

1 Values expressed as mean, S.E.M., (number of animals per group). Fluoride depletion regimen was started at beginning of day 0 .

2 These rats were instilled intratracheally with $200 \mu \mathrm{F}$ as $\mathrm{NaF}$ at the start of day 12 . 
FIGURE 22

Daily urinary ionic fluoride excretion of fluoride depleted rats versus time on low fluoride diet. Mean \pm S.E.M. is shown. Rats were placed on low F dietary regimen at the start of day 0 . 


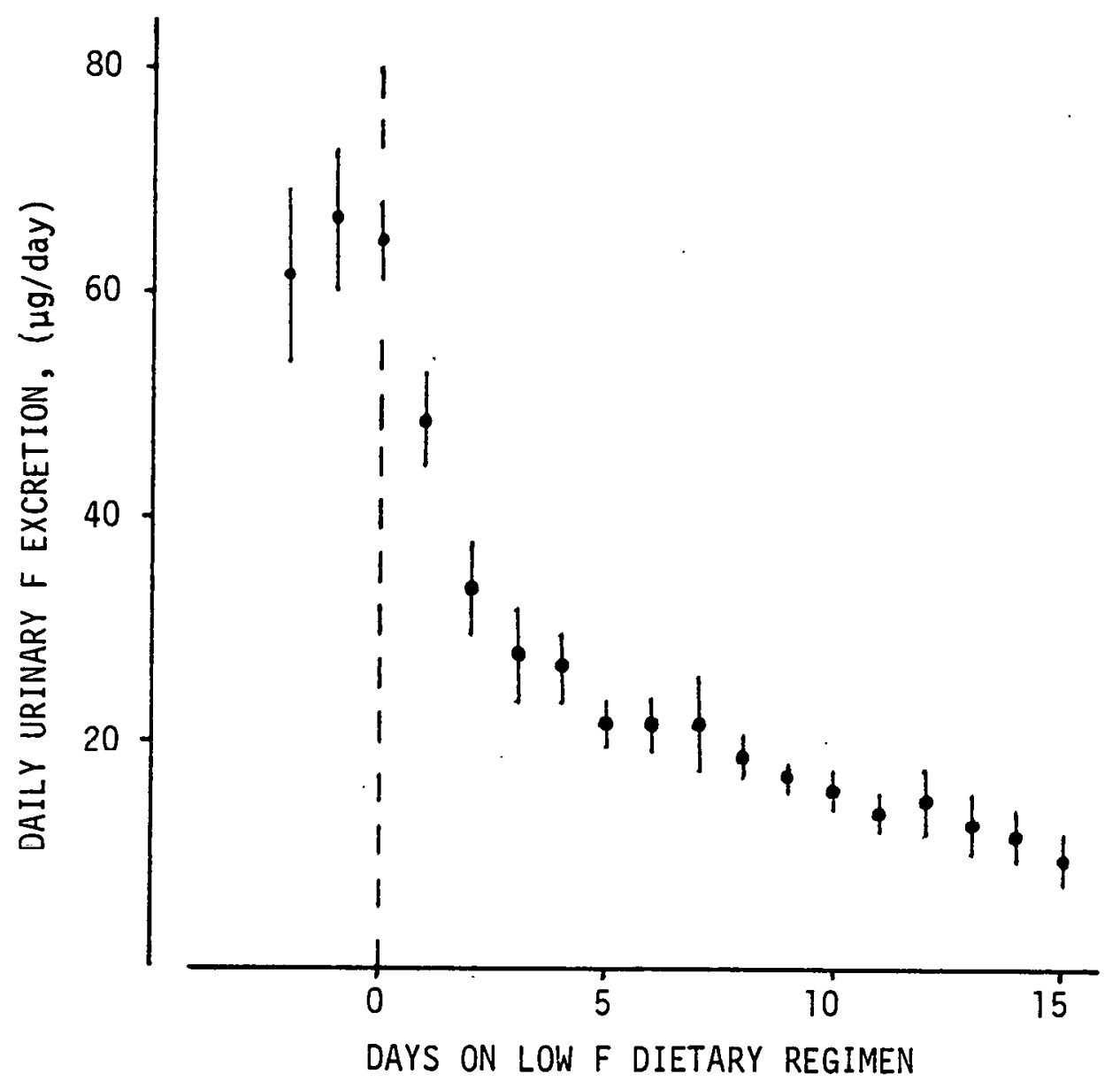




\section{FIGURE 23}

Log of the mean daily urinary ionic fluoride excretion of fluoride depleted rats versus time on low fluoride diet. The linear regimen line for days $2-15$ is shown $(r=.99, d f=14, p<.01)$. 


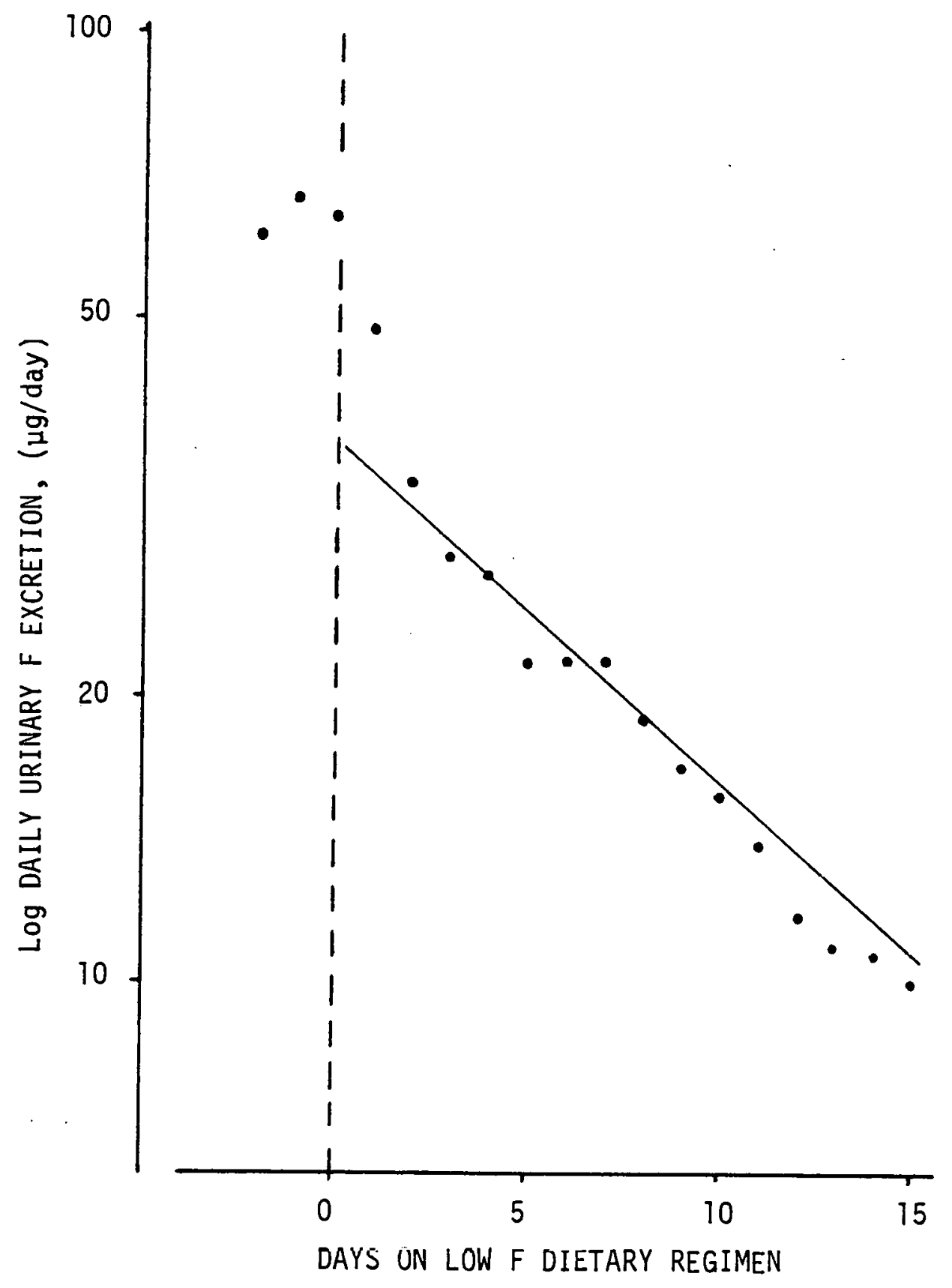


experimental conditions $F$ taken in previously under normal dietary conditions was being cleared from the rat with a half-time 8.3 days.

The urine samples collected on experimental days 6-15 were pooled by day and then ashed for determination of total fluoride content. Total F concentration exceeded ionic fluoride concentration in 8 of the 10 samples analyzed (Table 53). The mean $\Delta \mathrm{F}$ concentration for the 10 urine pools was $0.2 \pm .06 \mathrm{mg} / \mathrm{ml}$ (mean \pm S.E.M.). $\Delta F$ concentrations similar to those in sham operated rats were obtained in urine pools from rats instilled intratrachaelly with $200 \mu \mathrm{g} \mathrm{F}$ (as NaF).

The total fluoride concentration in feces collected each day during the fluoride depletion experiment are shown in Figure 24. Feces were pooled prior to analysis with the exception of days 12-15. The mean fecal fluoride concentration on days 12-15 are plotted in this graph. As is evident, within 3 days after the start of low F diet the fecal fluoride concentration decreased from approximately $100 \mu \mathrm{g} / \mathrm{g}$ to approximately $2 \mu \mathrm{g} / \mathrm{g}$.

The urinary and fecal fluoride excretion in rats instilled intiatracheally with $200 \mu \mathrm{g} \mathrm{F}$ (as NaF) are given in Table 54. Only in urine collected from $0-24$ hours after instillation was the fluoride excretion elevated over control levels. The instilled rats excreted a mean of $19 \pm 38$ (mean \pm S.E.M.) of the instilled fluoride dose in their urine. Fecal fluoride concentrations were not significantly elevated in rats instilled intratracheally with fluoride. 
TABLE 53

$\begin{array}{cccc}\Delta F \text { CONCENTRATION IN URINE OF RATS DURING FLUORIDE DEPLETIONI } \\ \begin{array}{c}\text { Urine fluoride } \\ \text { Collection period } \\ \text { (day) }\end{array} \\ 0 & 4.6 & 5.0 & -0.4 \\ & \text { Total } & \begin{array}{c}\text { Ionic } \\ \text { I }\end{array} & \Delta \mathrm{F} \\ 6 & 1.2 & 1.20 & 0.0 \\ 7 & 1.3 & 1.23 & 0.1 \\ 8 & 1.5 & .92 & 0.6 \\ 9 & 1.3 & .93 & 0.4 \\ 10 & 1.1 & .96 & 0.1 \\ 11 & 1.1 & .81 & 0.3 \\ 12 & 1.1 & .84 & 0.3 \\ 13 & 1.1 & .91 & 0.2 \\ 14 & 0.9 & .74 & 0.2 \\ 15 & 0.7 & .68 & 0.0\end{array}$

Inst+1led 2

12

13

14
3.3

1.0

1.1

0.9

.93

.75

.57

$-0.2$

0.1

0.4

0.3

1 Urines were pooled prior to analysis. Fluoride concentrations determined on each urine pool are given. Fluoride concentration not corrected for cage wash water. Fluoride depletion regimen was started at beginning of day 0 .

2 These rats were instilled intratracheally with $200 \mu \mathrm{g} F$ as $\mathrm{NaF}$ at the start of day 12 . 
FIGURE 24

Mean fecal total fluoride concentration of fluoride depleted rats versus time on low fluoride diet. Rats were placed on low fluoride diet at the start of day 0 . 


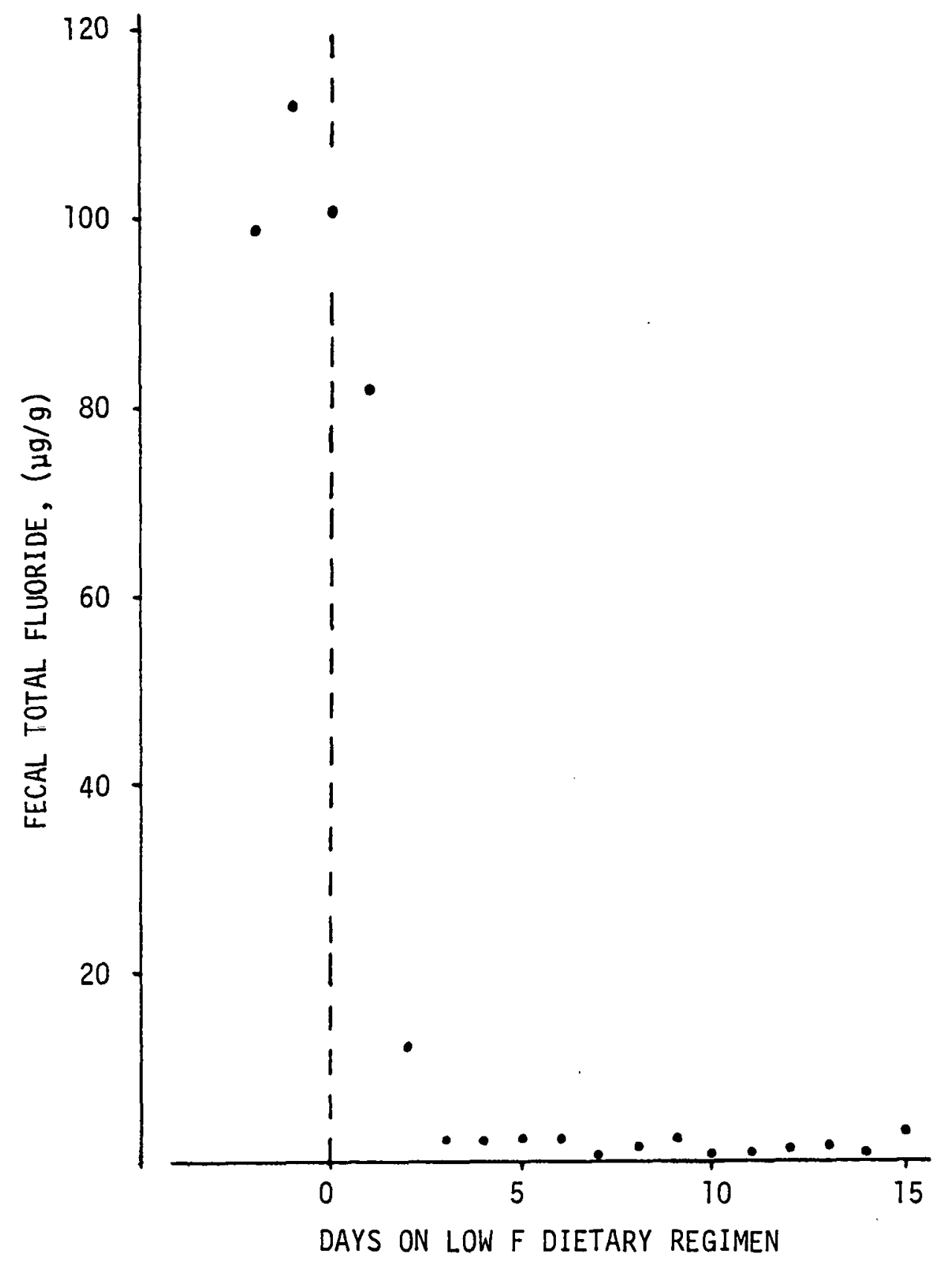




\section{TABLE 54}

URINARY IONIC FLUORIDE EXCRETION AND FECAL TOTAL

FLUORIDE CONCENTRATION IN PARTIALLY FLUORIDE DEPLETED RATS AFTER INTRATRACHEAL INSTILLATION

OF $200 \mu \mathrm{g} F$ AS NaF 1

$\begin{array}{lrrrrr}\begin{array}{l}\text { Days on F-depletion regimen } \\ \text { Hours after NaF instiliation }\end{array} & 11 & 12 & 13 & 14 & 15 \\ \text { Urine Ionic } F^{-}(\mu g \text { /day) } & & 0-24 & 24-48 & 48-72 & 72-96 \\ \text { Control } & & & & & \\ & 15 & 15 & 13 & 12 & 10 \\ & 3 & 3 & 2 & 2 & 2 \\ \text { Instilled } & (3) & (3) & (3) & (3) & (3) \\ & 13 & 53^{b} & 14 & 15 & 12 \\ & 1 & 5 & 1 & 1 & 1 \\ & (3) & (3) & (3) & (3) & (3)\end{array}$

Fecal Total $F(\mu \mathrm{g} / \mathrm{g})$

Control

0.8

1.3

.4

(3)

1.8

0.3

(3)

1.7

$(3)^{3}$

(3)
1.3

0.6

(3)
$0.7 \quad 3.6$

$0.4 \quad 1.4$

(3) (3)

$\begin{array}{ll}0.5 & 2.5\end{array}$

$0.3 \quad 1.1$

(3) (3)

1 Values expressed as mean, S.E.M., (number of animals per group). Fluoride depletion regimen was started at the beginning of day 0 .

b $\quad p<0.01$ compared to control. 


\section{Fluoride Injection}

After 1 control day in metabolism cages 13 partially fluoride depleted (II full days on low F regimen) and 6 normal $F$ intake male Long Evans rats were injected intraperitoneally with $200 \mu \mathrm{g} \mathrm{F}$ $(0.2 \mathrm{ml}, 1000 \mu \mathrm{g} \mathrm{F} / \mathrm{ml}$ as $\mathrm{NaF})$ and returned to their respective cages. Excreted urine and feces were then collected for timed periods throughout the succeeding 96 hours. This experiment was performed to 1) obtain a larger sample size for the determination of the percent of an acute fluoride dose which is excreted in the urine, 2) determine if differing routes of administration would affect the urinary fluoride excretion (i.p. vs i.t.), and 3 ) determine if fluoride depletion altered this response (normal vs low $\mathrm{F}$ diet). Urine samples were collected individually, feces were pooled by group. The fluoride depleted rats were injected in two groups, one group of 9 , and the other group of 4 rats. No soft tissues were collected from these rats because previous experiments had shown that fluoride was not retained for 96 hours after treatment.

Injection (i.p. or 1.t.) of $200 \mu \mathrm{g} F$ was without effect on kidney function as measured by urine volume or specific gravity (Table 55). The data following both routes of administration were similar and were, therefore, combined for this table. Food and water consumption were measured daily and were unchanged by injection. The mean body weight of rats used in this experiment was approximately $300 \mathrm{~g}$. The urinary fluoride excretion in fluoride depleted rats was elovated only during the $0-24$ perlod after 
TABLE 55

RENAL EFFECTS IN FLUORIDE DEPLETED RATS OF INTRATRACHEAL OR INTRAPERITONEAL INJECTION OF $200 \mu \mathrm{g} F$ AS NaFl
Collection period
(hours)
Urine Volume
(mi)
$-24-02$
8.9
$(16)^{9}$
1.064
.005
$0-24$
8.5
.6
(16)
$24-48$
8.4
.6
(16)
(16)
$48-72$
7.6
.8
(16)
1.059
.005
$72-96$
9.3
(10)
1.063
.004
(16)
(16)
1.077
.007
(16)
1.063
.004
(16)

Urine sp. gr.

1 Values expressed as mean, S.E.M., (number of animals per group).

2 Control period, fluoride injected at time 0. 
injection (Table 56). The response was similar after either interperitoneal or intratracheal injection. The excess fluoride excretion, calculated by subtracting the fluoride excreted on the control day from that excreted during the 24 hour period after injection averaged $44.9 \mu \mathrm{g} \pm 9.1$ (mean \pm std. dev.). This corresponds to $22 \pm 58$ (mean \pm std. dev.) of the administered dose. Dietary fluoride status did not affect the percent of an acute fluoride dose excreted in the urine within 24 hours (Table 57). Urine excreted by these rats was collected during the 24 hours previous to injection, from $0-7$ hours post-injection, and from 7-24 hours post-injection. The fluoride excretion from 0-24 hours post-injection is the sum of that excreted in the $0-7$ and 7-24 hour periode.

Excess fluoride excretion due to injection was calculated by subtracting the appropriate control value for each rat. As can be seen, in fluoride depleted rats the major portion $(83 \%)$ of the excess fluoride excretion due to injection of $F$ was excreted in the first 7 hours post injection. Fluoride excretion in these rats was not elevated $24-48,48-72$, or 72-96 hours post-injection (Table 54, group of 4). The response to fluoride injection in normal $F$ rats was no different than in $F$ depleted rats (Table 57). Normal F rats excreted a mean of $47 \mathrm{\mu g}$ excess $F$ or $24 \%$ of the injected dose during the first 24 hours post-injection. The major portion (798) of the excess fluoride to be excreted by these rats was also excreted $0-7$ hours post-injection. 
TABLE 56

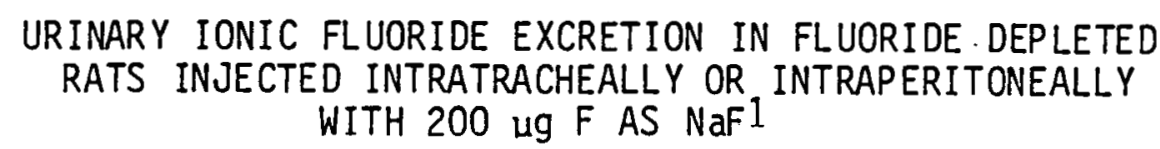

Route of administration

Intratracheal

Intraperitoneal

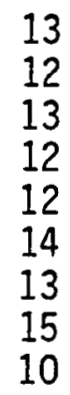
-24-0 hr.2 ( $\mu \mathrm{g} /$ day)

$0-24 \mathrm{hr}$ ( $\mu \mathrm{g} /$ day)
24-48 hr ( $\mu \mathrm{g} /$ day)

48-72 hr. 72-96 hr. ( $\mu \mathrm{g} /$ day) ( $\mu \mathrm{g} /$ day)

$\begin{array}{ll}13 & 49 \\ 11 & 47 \\ 14 & 6\end{array}$

49
47
64

14

15

13

16

10

10

13

11

11

64

55

60

49

58

51

63

56

43

13

15

14

13

14

11

12

11

12

$\begin{array}{rr}10 & 11 \\ 10 & 11 \\ 12 & 13 \\ 9 & 11 \\ 11 & 12 \\ 9 & 10 \\ 14 & 13 \\ 12 & 13 \\ - & 9\end{array}$

Intraperitoneal

15
12
11
14

56
55
75
77

14
15
17
15

7
11
15
11

8
10
13
12

1 The urinary fluoride

1 The urinary fluoride excretion of each rat is reported individualiy.

2 Control period, fluoride injected at time 0. 
TABLE 57

URINARY IONIC FLUORIDE EXCRETION IN NORMAL F RATS

AND FLUORIDE DEPLETED RATS INJECTED

INTRAPERITONEALLY WITH $200 \mu \mathrm{g} F$ AS NaF1

\begin{tabular}{|c|c|c|}
\hline $\begin{array}{l}r^{2} \\
\text { iod) }\end{array}$ & $\begin{array}{c}0-7 \mathrm{hr} \\
\text { ( } \mu \mathrm{g} / \mathrm{period})\end{array}$ & $\begin{array}{c}7-24 \mathrm{hr} \\
\text { (ug/period) }\end{array}$ \\
\hline
\end{tabular}

Fluoridedep leted

15
12
11
14
43

34

51

61
13

21

24

16
56

55

75

77

Excess fluoride 4

excretion-mean

\pm S.E.M.

44

$\pm 6$

9
+3

53

$\pm 6$

Normal fluoride

58

26

51

77

$48 \quad 27$

49

63

24

60

55

87

73

105

60

57

45

40

27

79

118

145

28

Excess fluoride 4

excretion-mean

\pm S.E.M.

37

$+13$

10

$\pm 5$

47

$\pm 10$

1 The urinary ionic fluoride excretion of each rat is reported individually.

2 Control period, fluoride injected at time 0.

3 Urine was collected from each rat from $0-7$ hours and from 7-24 hours. The fluoride excretion from $0-24$ hours is calculated as the sum of that excreted during these two periods.

4 Excess fluoride excretion for each rat was calculated by subtracting the appropriate control value for that rat. The control value for the 0-7 hour and 7-24 hour period was calculated as $7 / 24$ or $17 / 24$, respectively, of the 24 hour urinary fluoride excretion during the control day. 
The mean fecal fluoride concentrations in $F$ depleted rats after injection of fluoride are shown in Table 58. Feces were pooled by group in rats injected intraperitoneally. The feces excreted by each control and intratracheally injected rat were analyzed separately and the mean value given. The S.E.M. for these latter two groups is given in Table 54. The fecal fluoride concentration was not altered by intratracheal injection of $200 \mathrm{\mu g} \mathrm{F}$. However, intraperitoneal injection of $200 \mu \mathrm{g} F$ appeared to result in a slight elevation in fecal fluoride concentrations in the first 24 hours. If these elevations are real, approximately $2 \%$ of the intraperitoneal dose of fluoride was excreted via the feces.

The results of this and the preceding experiment indicated the desirability of using fluoride depleted rats for an HF retention experiment. The fluoride depletion regimen resulted in a 50-fold decrease in fecal fluoride concentration and a 6-fold decrease in urinary fluoride excretion without altering the manner in which the rat metabolized an acute fluoride dose. However, the use of fluoride depleted rats is complicated by the fact that both the urinary fluoride excretion and soft tissue fluoride concentration appear to be a function of the length of time on the low fluoride dietary regimen.

\section{E. Upper Respiratory Tract Exposure}

The results of several of the previous experiments pointed out the possibility that a significant fraction of inhaled HF is deposited in the upper respiratory tract. Comparison of the pulmonary retention kinetics of fluoride in the whole body $\mathrm{HF}$ 
TOTAL FECAL FLUORIDE EXCRETION IN FLUORIDE DEPLETED RATS INJECTED WITH $200 \mu \mathrm{g} F$ As $\mathrm{NaF}^{1}$

\begin{tabular}{|c|c|c|c|c|c|c|}
\hline $\begin{array}{l}\text { Route of } \\
\text { administration }\end{array}$ & $\begin{array}{c}-24-0 \mathrm{hr} .{ }^{2} \\
(\mu \mathrm{g} / \mathrm{g})\end{array}$ & $\begin{array}{l}0-24 \mathrm{hr} . \\
(\mu \mathrm{g} / \mathrm{g})\end{array}$ & $\begin{array}{l}24-48 \mathrm{hr} . \\
(\mu \mathrm{g} / \mathrm{g})\end{array}$ & $\begin{array}{l}48-72 \mathrm{hr} . \\
(\mu \mathrm{g} / \mathrm{g})\end{array}$ & $\begin{array}{l}72-96 \mathrm{hr} . \\
(\mu \mathrm{g} / \mathrm{g})\end{array}$ & $\begin{array}{l}\text { Mean fecal } \\
\text { dry weight } \\
(\mathrm{g})\end{array}$ \\
\hline Control & 0.8 & 1.3 & 1.8 & 0.7 & 3.6 & 0.9 \\
\hline $\begin{array}{l}\text { Intraperitoneal } \\
\text { (group of } 9)\end{array}$ & 0.6 & 5.6 & 1.4 & 0.6 & 0.0 & 1.1 \\
\hline $\begin{array}{l}\text { Intraperitoneal } \\
\text { (group of } 4 \text { ) }\end{array}$ & & 4.6 & 2.4 & 0.0 & 0.0 & 1.0 \\
\hline Intratrachael & & 1.7 & 1.3 & 0.5 & 2.5 & 1.1 \\
\hline
\end{tabular}


retention experiment with the estimated inhalation rate of $\mathrm{HF}$ suggested that as much as 998 of inspired $\mathrm{HF}$ may be removed from the air by the upper respiratory tract. The pulmonary fluoride burden in rats exposed to $\mathrm{HF}$ plus water vapor was markedly lower than in rats exposed to similar concentrations of $\mathrm{HF}$ alone, yet the body burdens of fluoride, as measured by plasma fluoride concentration, in both groups of rats were quite similar. One possible explanation for these results was that water vapor alters the regional deposition pattern of inhaled $\mathrm{HF}$ without affecting the total amount deposited. This same phenomenon would also explain the differences in pulmonary fluoride burdens in Blue Spruce and Charles River rats after exposure to similar HF levels. It should be stated, however, that there are several other possible explanations for each of these results. It was not the conclusiveness of the observations but the frequency with which they occurred which led to the performance of the experiment to be described in this section.

The basic design of this experiment was to measure the concentraton of $\mathrm{HF}$ in air entering the external nares and in air entering the trachea, (in air which had passed through the upper respiratory tract). The term upper respiratory tract as used here refers to all regions of the respiratory tract cephalad to the trachea. Any difference in airborne fluoride concentrations at these two locations would be attributed to deposition of HF in the upper respiratory tract. Measurement of airborne fluoride concentration entails drawing air at a known flow rate through a 
collecting agent, measuring the amount of fluoride collected, and expressing it per unit volume of air sampled. Chamber air samples were $\mathrm{drawn}$ at $0.77 \mathrm{l} / \mathrm{min}$ for one minute. Measurement of airborne fluoride levels in the trachea of the intact $r$ at by this technique would not only interfere with the animals' respiration, but the respiratory process would interfere with sample collection. Therefore, it was decided to sever the trachea completely and allow the rat to respire rocm air spontaneously through an endotracheal tube which lead caudally towards the lung. A second endotracheal tube was inserted in the trachea towards the mouth. PE 190 tubing was used to connect the latter endotracheal tube to an air sampler. This air sampler drew chamber air through the upper respiratory tract into the upper trachea and then through 2 midget impingers each containing a HF collection fluid (TISAB). Division of the amount of fluoride collected in the impingers by the volume of air sampled gave the fluoride concentration in tracheal air, i.e., in air that had passed through the upper respiratory tract. These tracheal air samples were drawn for 5 minute periods at a phyaiological flow rate of $0.14 \mathrm{liter} / \mathrm{min}$. Since some of the air drawn into the trachea may pass through the oral cavity instead of the nasal cavity the head of each experimental rat was inserted in the HF chamber to such an extent that the entire muuth was exposed to the HF atmosphere, thus, eliminating the possibility that any non-HF containing air might be drawn into the trachea.

The exact experimental protocol was also influenced by other considerations. Any vasocongestion or loralized edema in the hasal 
cavity induced by HF might be expected to alter the collection efficiency of this region by reducing the airway diameter. That such a process might occur was demonstrated in the dose-response experiment in which rats were observed to emit fluid from their external nares. Consequently, it was decided to draw several air samples through the upper respiratory tract to determine if the collection efficiency was altered by exposure to HF. A 5 minute period separated each 5 minute tracheal air sample collection period. This protocol not only provided some time for toxic effects to develop but allowed equal time periods when the nasal cavity was exposed to HF (mimicking the inspiratory phase of respiration in the intact $r a t$ ) and when it was not exposed to $\mathrm{HF}$ (mimicking the expiratory phase of respiration in the intact rat). In this experiment it was also hoped to determine if exposure of only upper respiratory tract alone resulted in increased systemic burdens of fluoride as measured by increased plasma fluoride concentration. To this end it was necessary that rats be exposed to significant amounts of $\mathrm{HF}$ and that there be sufficient time for some absorption of fluoride to occur. The experimental protocol used (Figure 25) fits all these criteria.

Immediately after the end of the last tracheal air sample the thoracic cavity was opened and blood withdrawn by cardiac puncture. The upper respiratory tract was rinsed once with $4 \mathrm{ml}$ doubled distilled water. By this rinsing procedure it was hoped to determine qualitatively if this exposure regimen resulted in increased fluoride concentrations in the upper respiratory tract. 
FIGURE 25

Exper imental protocol for upper respiratory tract exposure. 


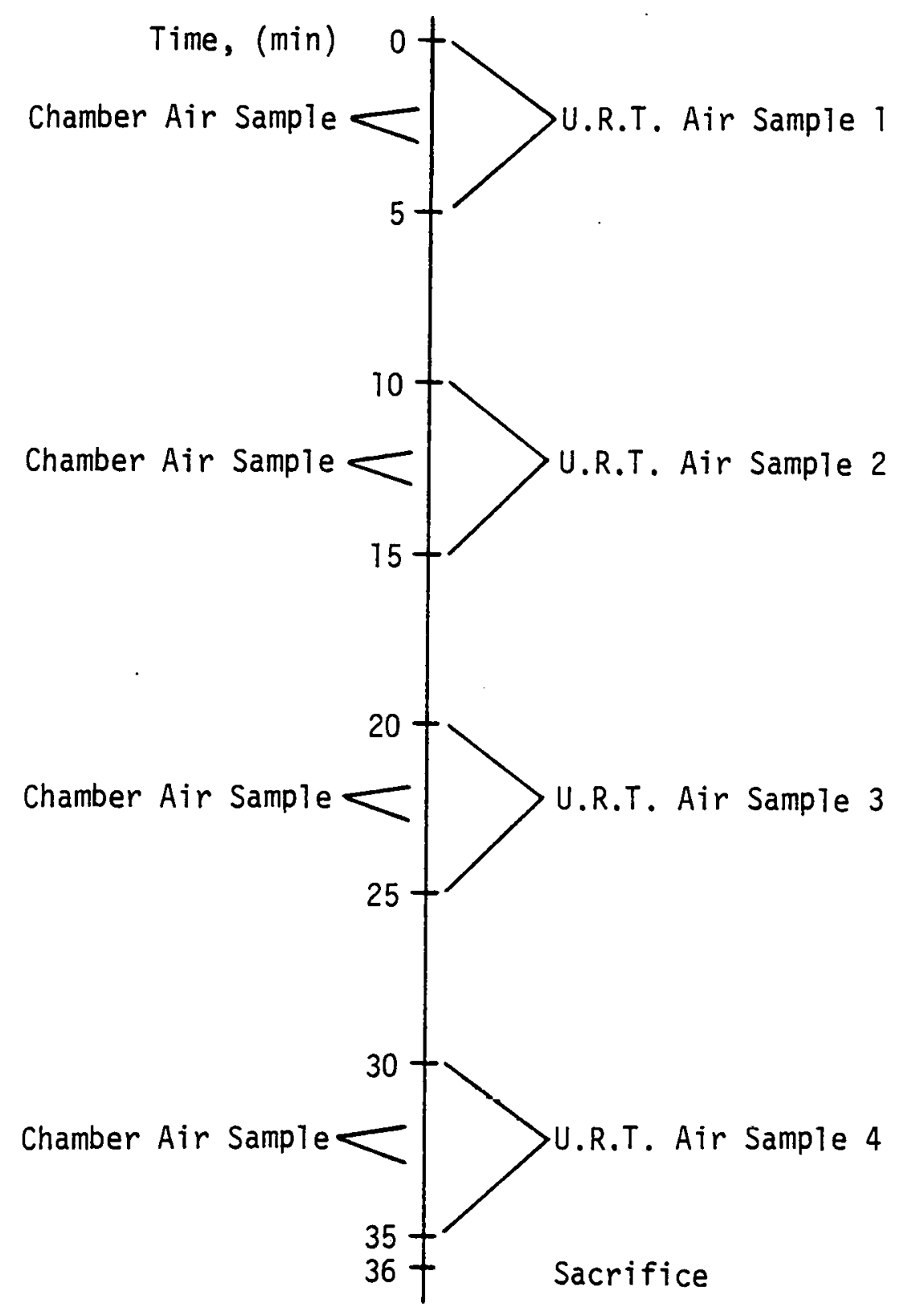


Prior to the experiment both air samplers were calibrated with a dry gas meter and then against each other by drawing concurrent air samples from HF chamber atmospheres. The measured airborne $F$ concentration measured with the slow flow rate sampler $(0.14 \mathrm{l} / \mathrm{min}$ $x 5 \mathrm{~min}$ ) averaged $98 \pm 148$ (mean \pm std. dev.) of the concentration determined by the high flow rate sampler $(0.771 / \mathrm{min} \times 1 \mathrm{~min})$. Since the upper respiratory tract provides some resistance to flow there will be a slight pressure drop in air passing through this site. However, the expected pressure drop is not large enough to significantly alter the calibration of the rotameter used to measure air flow rate (Mercer, 1973). The rate at which bubbles formed in the HF collection medium provided an independent, albiet crude, way to monitor the air flow through the sampler system. No difference in the rate of bubble formation could be discerned when a rat was placed into or removed from the system.

Rats were subjected to this exposure regimen individually, thus each rat was exposed to slightly different airborne fluoride concentrations. The first group of 4 male Long Evans rats was exposed to $96 \pm \sigma \mathrm{mg} \mathrm{r} / \mathrm{m}^{3} \mathrm{HF}$ (mean \pm S. E,M.). Another group of: rats was exposed to a higher concentration $\left(176 \pm 4 \mathrm{mg} F / \mathrm{m}^{3}\right)$ and a third group to a lower concentration $\left(36 \pm 4 \mathrm{mg} \mathrm{F} / \mathrm{m}^{3}\right)$. One group of control rats were exposed to room air by the same protocol as for HF. Another group was surgically prepared and placed in the HF chamber (concentration $74 \mathrm{mg} \mathrm{F} / \mathrm{m}^{3}$ ) but no air was drawn through the upper respiratory tract. This exposure was performed to dctermine if any HF was absorbed due to a proccess other than 
flow through the upper respiratory tract. The chamber air temperature averaged $25^{\circ} \mathrm{C}$, the relative humidity ranged between 17 and 258. Animals were kept warm with a 250 watt heat lamp. The heat lamp also warmed the tracheal air sampling tube and thereby helped to minimize condensation.

The limit of detection of airborne fluoride under the sampling conditions used in this experiment was $0.1 \mathrm{mg} \mathrm{F} / \mathrm{m}^{3}$. Detectable amounts of $\mathrm{HF}$ were not present in the tracheal air of rats exposed to any chamber HF concentration (Table 59). Detectable amounts of fluoride were not collected in either the first or the second midget impinger. Under these conditions the HF collection efficiency of the upper respiratory tract was greater than 99.78 or 99.98 depending on the chamber airborne fluoride concentration. It is interesting to note that airborne $\mathrm{HF}$ drawn through $10 \mathrm{ml}$ of TISAB at a much greater flow rate of $0.771 / \mathrm{min}$ is collected with similar or greater efficiency. Since detectable amounts of HF never penetrated the upper respiratory tract it was not possible to determine if $\mathrm{HF}$ exposure altered the collection efficiency of this region.

Significant amounts of fluoride could be rinsed out of the upper respiratory tract of exposed rats indicating that HF had depusited in that site. This is not a quantitative measure of the fluoride prescnt in the upper respiratory tract, it merely indicates, as in the case of rats exposed to $36 \mathrm{mg} \mathrm{F} / \mathrm{m}^{3}$ that at least $22 \mu \mathrm{g}$ of fluoride was present in this site. The rinse contained no blond as lonq as no blood was present in the trachea 
TABLE 59

CONCENTRATION OF HF IN CHAMBER AIR AND TRACHEAL AIR OF UPPER RESPIRATORY TRACT (U.R.T.) EXPOSED RATS

\begin{tabular}{|c|c|c|c|c|}
\hline group & $\begin{array}{l}\text { Chamber air } \\
\mathrm{HF} \text { concentration } 1 \\
\left(\mathrm{mg} \mathrm{F} / \mathrm{m}^{3}\right)\end{array}$ & $\begin{array}{l}\text { Tracheal air } \\
\text { HF concentration } 2 \\
\left(\mathrm{mg} \mathrm{F} / \mathrm{m}^{3}\right)\end{array}$ & $\begin{array}{l}\% \text { removed } \\
\text { by U.R.T. }\end{array}$ & $\begin{array}{c}\text { Fluoride present } \\
\text { in U.R.T. rinse } 1 \\
(\mu g)\end{array}$ \\
\hline Control & -- & -- & -- & $0.02 \pm .00(4)$ \\
\hline $\begin{array}{l}\text { Control } \\
\text { no air drawn } \\
\text { through U.R.T. }\end{array}$ & 74 & -- & -- & $5.6 \pm 1.3(3)$ \\
\hline \multirow[t]{3}{*}{ Exposed } & $36 \pm 4(4)$ & $<0.1$ & $>99.7$ & $22 \pm 3.1$ (4) \\
\hline & $96 \pm 6(4)$ & $<0.1$ & $>99.9$ & \\
\hline & $176 \pm 4(4)$ & $<0.1$ & $>99.9$ & 67,673 \\
\hline
\end{tabular}

1 Values expressed as mean \pm S.E.M. (number of animals per group). HF generated by compressed gas technique.

2 Limit of detection of airborne fluoride method is $0.1 \mathrm{mgF} / \mathrm{m}^{3}$, detectable concentrations of fluoride were not detected in the tracheal air of any rat.

3 U.R.T. of only two reported, each value given. 
when the endotracheal tube was inserted. In the course of the experiment very small amounts of fluid are sucked into the upper respiratory tract sampling tube, but this usually did not interfere with the collection process. Large amounts of fluid were sucked into the endotracheal sampling tube of rats exposed to $176 \mathrm{mg}$ $\mathrm{F} / \mathrm{m}^{3}$. In two rats the sampling tube became plugged with this fluid during collection of the third air sample. This high airborne HF concentration may be inducing edema formation and/or excess mucous secretion in the nasal cavity. A similar effect, discharge of fluid from the external nares, was observed in rats exposed to high concentrations of $\mathrm{HF}$ in the dose-response experiment. The upper respiratory tract rinsing procedure removed $35 \mu \mathrm{g}$ of fluoride from these rats through which only two tracheal air samples were drawn, as opposed to $67 \mu \mathrm{g}$ in the two rats which had four tracheal air samples drawn. The small amount of fluoride rinsed from the upper respiratory tract of the $74 \mathrm{mg} F / \mathrm{m}^{3}$ control group may have been due to diffusion of $\mathrm{HF}$ into the nasal cavity and deposition in that site or to deposition of $\mathrm{HF}$ on the external nares.

The plasma ionic fluoride concentrations in upper respiratory tract exposed rats are shown in Figure 26. As can be seen a dose-dependent increase in plasma fluoride concentration occurred indicating a cause and effect relationship. The plasma ionic fluoride concentration in rats exposed to room air (group C) was $0.11 \pm .002(4) \mu \mathrm{g} / \mathrm{ml}[$ mean $\pm \mathrm{SEM}(\mathrm{n})]$. In rats whose heads were placed in the HF chamber but through which no air was drawn 
FIGURE 26

Plasma ionic fluoride concentration of upper respiratory tract exposed rats versus airborne HF exposure concentration. Each point represents a single rat. Mean plasma ionic fluoride concentrations of rats exposed to room air (C) and rats placed in HF atmosphere but which had no air drawn through the upper respiratory tract (N) are shown. 


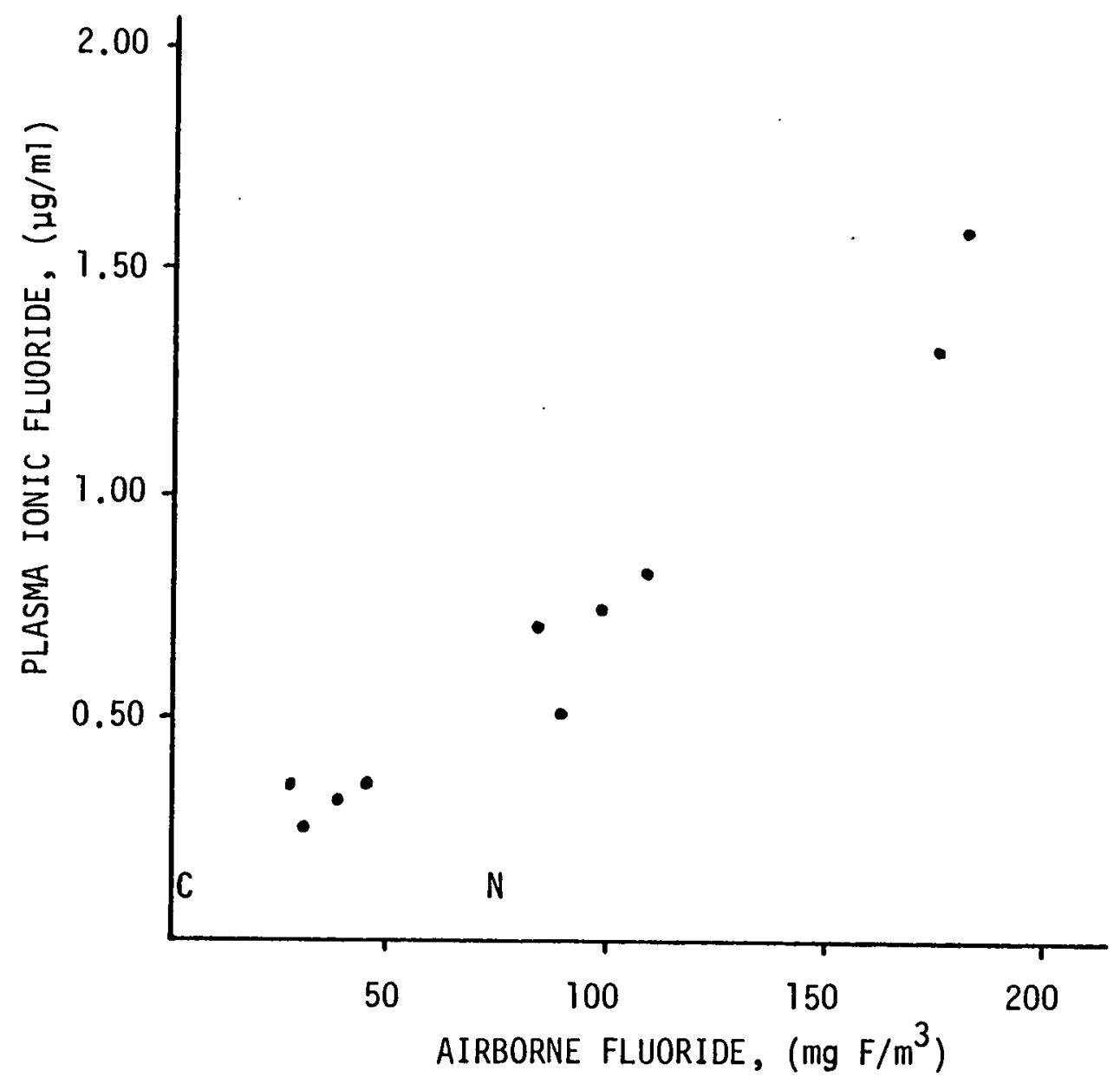


(group $N$ ) the plasma ionic fluoride concentration was $0.11 \pm 0.002$ (3) $\mu \mathrm{g} / \mathrm{ml}$ Imean $\pm \operatorname{SEM}(n)]$. Comparison of these fluoride levels indicates that the elevated fluoride concentration in upper respiratory tract exposed rats can only be due to HF which was drawn through the upper respiratory tract. Total fluoride concentration was not determined on plasma samples from upper respiratory tract exposed rats.

In Table 60 , the airborne fluoride drawn through the upper respiratory tract and the estimated systemic body burden of fluoride are compared. Since both the flow rate of air drawn into the trachea and the airborne HF concentration are known, the fluoride dose can be reasonably estimated. To estimate the systemic body burden of fluoride it was assumed that the body contained 608 water and that the average ionic fluoride concentration in body water was one-half that in plasma. It has been estimated that intracellular fluoride concentrations average approximately 508 of that in plasma (Wallace-Durbin, 1954; Carlson et al., 19600). Deposition in bone was ignored even though siynificant amounte of skeletal fluoride deposition could have occurred during the time course of this experiment (Wallace-Durbin, 1954). Even with these conservative assumptions it is estimated that approximately 208 of the fluoride drawn through the upper respiratory tract is absorbed into the body in the 36 minutes of the experiment. Thus absorption of HF from the upper respiratory tract appears to be fairly rapid. 


\section{TABLE 60}

COMPARISON OF FLUORIDE DRAWN THROUGH UPPER RESPIRATORY

TRACT (U.R.T.) AND ESTIMATED ABSORBED FLUORIDE BURDEN AT END OF EXPOSURE 1

\begin{tabular}{|c|c|c|c|c|c|}
\hline $\begin{array}{l}\text { Chamber air } \\
\mathrm{HF} \text { concentration } \\
\left(\mathrm{mg} \mathrm{F} / \mathrm{m}^{3}\right)\end{array}$ & $\begin{array}{l}\text { Fluoride drawn } \\
\text { through U.R.T.2 } \\
(\mu \cdot)\end{array}$ & $\begin{array}{l}\text { Plasma ionic } \\
\mathrm{F}^{-} \text {concentration } \\
\quad(\mu \mathrm{g} / \mathrm{m} \mathrm{l})\end{array}$ & $\begin{array}{c}\text { Body wt. } \\
\text { (g) }\end{array}$ & $\begin{array}{l}\text { Absorbed } \\
\text { fluoride } 3 \\
\quad(\mu g)\end{array}$ & $\begin{array}{c}\text { Absorbed } \\
\text { fluoride } \\
\qquad(\%)\end{array}$ \\
\hline Conะrol & -- & 0.11 & & & \\
\hline 36 & 101 & 0.31 & 289 & 18 & 18 \\
\hline $9 \hat{b}$ & 269 & 0.70 & 268 & 48 & 18 \\
\hline 177 & 496 & 1.46 & 290 & 117 & 24 \\
\hline
\end{tabular}

1 Mean value for each group is given. HF generated by compressed gas technique.

2 Four $5 \mathrm{~min}$. $0.14 \mathrm{l} / \mathrm{min}$ air samples drawn through U.R.T.

3 Absorbed fluoride calculated assuming body water comprises $60 \%$ of the body weight and the mean body water fluoride concentration equals one-half that in plasma. (Plasma values of exposed rats corrected for control level prior to calculation).

4 Expressed as \% of fluoride drawn through U.R.T. 
F. HF Retention in Fluoride Depleted Rats

In this final experiment anaesthetized fluoride depleted male Long Evans rats obtained from Blue Spruce Farms were exposed to HF in the nose-only exposure unit for 1 hour and were sacrificed 1, 7, 12, 24 or 96 hours after the start of exposure. All rats were sacrificed 15 days after the placement on the low F dietary regimen. Thus, rats were exposed at various times from 11 to 15 days after initiation of this dietary regimen. This sacrifice protocol was used because the dietary fluoride status had no effect on the metabolism of fluoride after an acute dose, while the soft tissue fluoride concentrations were dependent on the length of time on the low $F$ diet regimen.

Rats were exposed to HF in groups of 3 or 4 . The airborne fluoride concentrations for each exposure group are given in Table 61. Both time weighted average fluoride concentration and the mean \pm standard deviation of the 7 airborne fluoride measurements made during each exposure are given. Exposure concentrations ranged from $57-68 \mathrm{mg} \mathrm{F} / \mathrm{m}^{3}$. No mean exposure concentration was statistically different from any other. The chamber relative humidity was measured prior to each exposure and ranged between 13 and 268. Exposure chamber temperature averaged $25^{\circ} \mathrm{C}$. The mean urinary fluoride excretion during the 0-7 hour experimental period was determined in all groups of rats sacrificed at 7 hour or longer times and is given in this table as a measure of the biologic response to HF. As can be seen, the slight deviations in HF 
EXPOSURE CONDITIONS FOR FLUORIDE DEPLETED RAT HF RETENTION EXPERIMENT

\begin{tabular}{|c|c|c|c|c|}
\hline Sacrifice time & $\begin{array}{l}\text { Airborne } \\
\text { (T.W.A.) } \\
\mathrm{mg} \mathrm{F} / \mathrm{m}^{3}\end{array}$ & $\begin{array}{l}\text { oride concentration } \\
\text { an } \pm \text { Std. Dev.) } \\
\mathrm{mg} \mathrm{F/m} 3\end{array}$ & $\begin{array}{c}\text { Relative } \\
\text { humidity } \\
\qquad \%\end{array}$ & $\begin{array}{l}\text { Urinary Ionic } \mathrm{F}^{-1} \text {. } \\
\text { excretion during } \\
0-7 \text { hour period } \\
(\mu \mathrm{g})\end{array}$ \\
\hline Control & & & & $6.6 \pm 0.6$ \\
\hline 1 hour ? & 63 & $64 \pm 9$ & $13 \%$ & \\
\hline$"$ & 61 & $59 \pm 9$ & $13 \%$ & \\
\hline$"$ & 62 & $62 \pm 3$ & $13 \%$ & \\
\hline$"$ & 68 & $57 \pm 10$ & $13 \%$ & \\
\hline 7 hour & 57 & $57 \pm 7$ & $13 \%$ & $101 \pm 11$ \\
\hline 12 hour & 68 & $68 \pm 8$ & $21 \%$ & $78 \pm 13$ \\
\hline 24 hour & 68 & $71 \pm 15$ & $26 \%$ & $118 \pm 15$ \\
\hline 96 hour & 68 & $68 \pm 8$ & $13 \%$ & $120 \pm 24$ \\
\hline
\end{tabular}

1 Values expressed as mean, S.E.M. HF generated by compressed gas techniques.

2 Rats sacrificed at 1 hour were exposed individually. 
exposure concentration were of no significance biologically as measured by this parameter.

The pulmonary effects of nose-only exposure to $57-68 \mathrm{~m}$ ' $\mathrm{F} / \mathrm{m}^{3}$ HF for 1 hour are given in Table 62. The lung weight to body weight ratio was not significantly different from control levels in exposed rats sacrificed at any time. Two control exposures were performed in this experiment. Both groups of rats were anesthetized and exposed to room air in a similar nose-only exposure unit; one group of rats was sacrificed at 7 hours, the other at 48 hours. One control rat was sacrificed after 1 hour of anaesthesia. Blood was the only tissue sampled from this rat. The data on pulmonary effects were similar in all control animals and were, therefore, pooled to give one control group. The lung wet weight to dry weight ratios in HF exposed rats sacrificed at I hour and at 24 hours were statistically higher than in the control group. However, the increase was at best minimal, and the lung wet weight to $d r y$ weight ratio in these rats was no higher than observed in other control groups, viz. control rats sacrificed on days 4 or 14 in the whole body HF retention experiment and control rats sacrificed at $I$ and 7 hours in the infusion experiment. The respiratory frequency was determined during exposure in all groups of rats. This frequency was significantly lower than control levels in 4 of the 5 exposed groups. When the data from every exposed animal are treated as one group a respiratory frequency of $58.4 \pm 2.4$ (18) [mean \pm SEM $(n)]$ is obtained. This mean frequency 
TABLE 62

PULMONARY EFFECTS OF 1 HOUR NOSE-ONLY EXPOSURE TO APPROXIMATELY $63 \mathrm{mg} \mathrm{F} / \mathrm{m}^{3} \mathrm{HF} 1$

Sacrifice time BodyWt. BodyWt. $\quad \begin{aligned} & \text { Lung } \\ & \text { Wrywt. }\end{aligned} \begin{gathered}\text { Respirations } \\ \text { (breaths/min.) }\end{gathered}$ (g) $\quad(\mathrm{g} / \mathrm{kg})$

1 hour

7 hour

12 hour

24 hour

Control
303

11

(4)

4.51

.13

(4)

4.17

.11

(4)

4.56

.47

(3)

4.13

.11

(3)

3.87

.16

(4)

(4)

298

315

(7)

.17

(7) $4.80^{a}$

.06

(4)

4.66

.04

(4)

4.67

.02

(3)

4. $75^{b}$

.03

(3)

67

4

(4)

$61^{a}$

3

(4)

$53^{b}$

3

(3)

55

6

(3)

54

.06

(4)

(4)

4.65

79
6

(7)

1 Values expressed as mean, S.E.M. (number of animals per group). HF generated by compressed gas technique. Exposure started at time 0 . A 11 rats sacrificed on 15th day of fluoride depletion.

a $\quad p<0.05$ compared to control.

b $p<0.01$ compared to control. 
is significantly less than the control frequency of $79 \pm 6$ $(p<0.01)$ suggesting that $\mathrm{HF}$ is a sensory irritant (Alarie, 1973).

The renal effects of nose-only exposure to approximately $63 \mathrm{mg}$ $\mathrm{F} / \mathrm{m}^{3}$ HF for 1 hour are given in Table 63 . The kidney weight to body weight ratio was similar in all control and exposed groups. The BUN in controls sacrificed at 7 hours, and 48 hours were significantly different suggesting some effect of pentobarbital anaesthesia or control exposure on this parameter. At no sacrifice time following HF exposure was BUN elevated over control levels. Similarly, urine specific gravity was unaffected by HF exposure. $\mathrm{HF}$ exposure may have induced some changes in urine volume. Control rats excreted a mean of $10.4 \mathrm{ml}$ urine during the $0-24$ hour period and $14 \mathrm{ml}$ during the 24-48 hour period. The mean volumes of urine excreted by exposed rats during $24-48,48-22$, or $72-97$ hours were $10.5,9.3$ and $10.4 \mathrm{ml}$, respectively. While these mean volumes were significantly less than $14 \mathrm{ml}$ excreted by control rats from 24-48 hours they were not different from the mean volume of $10.4 \mathrm{ml}$ excreted by the control rats during the 0-24 hour period. The urine volumes were also no different from the mean levels excreted by rats in the fluoride depletion experiment. Thus, the volumes of urine excreted $24-48,48-72$ and $72-96$ hours after the start of HF exposure are in the normal range for control rats. The volume of urine excreted by exposed rats during the 0-7 hour period averaged 1748 of the $1.9 \mathrm{ml}$ excreted by control rats during the period, but groups were not statistically different. One exposed $r$ at excreted $12 \mathrm{ml}$ of urine during this period. It is not clear whether this 
TABLE 63

RENAL EFFECTS OF 1 HOUR NOSE-ONLY EXPOSURE TO APPROXIMATELY $63 \mathrm{mg} \mathrm{F} / \mathrm{m}^{3} \mathrm{HF}^{1}$

$\begin{array}{ccccc}\text { Group } & \text { Kidney Wt. } & \text { Urine } & \text { Urine } \\ \begin{array}{c}\text { Collection } \\ \text { period }\end{array} & \begin{array}{c}\text { BodyWt. } \\ (\mathrm{g} / \mathrm{kg})\end{array} & \begin{array}{c}\text { BUN } \\ (\mathrm{mg} \%)\end{array} & \begin{array}{c}\text { Volume } \\ (\mathrm{ml})\end{array} & \text { Sp. gr. }\end{array}$

Control

$0-7$ hour 2

7.67

.23

(3)

7-24 hour

24-48 hour

7.60
.23
$(4)$

HF Exposed

$0-1$ hour

7.55

.18

(4)

$0-7$ hour

7.43

.31

(4)

7-12 hour

7.84
.09

(3)

7-24 hour
12.7

.6

(3)

1.9

.2

(7)

8.5

.9

(4)

18.0

.8

(4)

14.

1.3

(4)

1.077

.011

(7)

1.061

.005

(4)

1.050

.004

(4)
.51

.13

(4)

14.3

(4)

3.3

(14)

17.8

1.0

(3)

1.6

.6

(3)

8.3

(7)

(7)

13.7

(3)
1.063 .001

(4)

1.062

.005

(14)
1.090

.0400

(3)

1.061

.003

(7)

(3) 
TABLE 63 (continued)

RENAL EFFECTS OF 1 HOUR NOSE-ONLY EXPOSURE TO APPROXIMATELY $63 \mathrm{mg} F / \mathrm{m}^{3} H \mathrm{~F}^{1}$

$\begin{array}{lcrrr}\begin{array}{c}\text { Group } \\ \begin{array}{c}\text { CoTlection } \\ \text { period }\end{array}\end{array} & \begin{array}{c}\text { Kidney Wt. } \\ \text { Body }(\mathrm{g} / \mathrm{kg})\end{array} & \begin{array}{c}\text { BUN } \\ (\mathrm{mg} \%)\end{array} & \begin{array}{c}\text { Urine } \\ \text { Volume } \\ (\mathrm{ml})\end{array} & \begin{array}{r}\text { Urine } \\ \text { Sp. gr. }\end{array} \\ 24-48 \text { hour } & & & 10.5 & 1.063 \\ & & & .3 & .003 \\ & & & (4) & (4) \\ 48-72 \text { hour } & & & 9.3 & 1.066 \\ & & & (4) & .003 \\ 72-96 \text { hour } & 6.88 & 18.3 & 10.4 & 1.064 \\ & (46) & (4) & (4) & .002 \\ & (4) & (4) & (4) & \end{array}$

1 Values expressed as mean, S.E.M., (number of animals per group). HF generated by compressed gas technique. Exposure started at time 0 . All rats sacrificed on 15th day of fluoride depletion.

2 Period of urine collection. Urines were collected from each rat during every period until time of sacrifice. When rats were sacrificed at the end of a collection period the kidney weight to body weight ratio and BUN are given. 
abnormally high value is due to fluoride toxicity or not. If this value is ignored the mean urine volume of exposed rats during this period was $2.6 \pm 0.2$ (13) Imean \pm SEM $(n)]$; a value significantly higher than control levels $(p<0.05)$. This HF exposure regimen, therefore, may have induced slight renal damage.

The measured fluoride concentrations in soft tissues of fluoride depleted rats after nose-only exposure to HF are given in Table 64. The ionic fluoride concentration in plasma of these control rats was higher than in control rats sacrificed on day 15 in the fluoride depletion experiment. This variation in fluoride concentrations suggests that unknown factors, perhaps fluoride intake prior to low F feeding, may affect the plasma fluoride concentration after 15 days on the low regimen. The consistency of the results within this experiment, however, suggest that within experiments the control or baseline fluoride concentrations are constant.

Total and ionic fluoride concentration in lung, plasma and kidney were significantly higher than control levels in rats sacrificed immediately after HF exposure ( 1 hour group). The ionic fluoride concentration in lung corrected for control levels averaged 558 of that in plasma. This ratio after continuous intravenous infusion of $10.8 \mathrm{mg} \mathrm{F} / \mathrm{min}$ was 388 . Thus, most, if not all of the innic fluoride present in the lungs of rats exposed to HF via the nose-only route can be explained on the basis of transport of ionic fluoride in the plasma. There is little 
TABLE 64

MEASURED FLUORIDE CONCENTRATIONS IN SOFT TISSUES OF RATS AFTER NOSE-ONLY EXPOSURE TO APPROXIMATELY

$63 \mathrm{mg} \mathrm{F} / \mathrm{m}^{3}$ HF FOR 1 HOUR 1

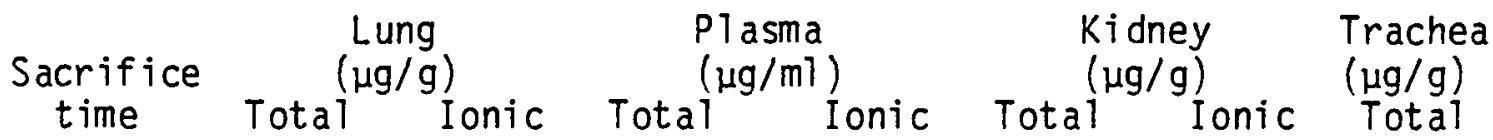

HF Exposed

1 hour $1.3 b$

$(\dot{4})$

7 hour

0.6

$(4)$

12 hour

0.4

(3)

24 hour 0.4

$(3)$

96 hour $0.2^{b}$

(4)

(4)

\begin{tabular}{rrr} 
Control & 0.7 & 0.07 \\
& $(7)$ & $(7)$ \\
& & \\
\hline
\end{tabular}

$0.19 b$

(4)

0.08

.00

(4).

$0.03^{a}$

.01

(3)

$0.04 a$

.00

(3)

0.06

.00

(4)

$\begin{array}{lrr}\text { Control } & 0.7 & 0.07 \\ & (7) & (7) \\ & & \\ \end{array}$

\begin{tabular}{rrr} 
Control & 0.7 & 0.07 \\
& $(7)$ & $(7)$ \\
& & \\
\hline
\end{tabular}

$0.59 b$

.10

(4)

0.14

.01

(4)

.010

(4)

$0.09 a$

(3)

$0.066^{b}$

.006

(3)
$1.9 b$

.2

(4)

0.8

.1

(4)

0.3

.0

(3)

$0.058^{\mathrm{a}}$

.006

(3)
0.3

.0

(3)
0.44

.08

(4)

$0.13^{b}$

.01

(4)

0.06

.01

(3)

0.06

.00

(3)

0.2

(3)

(3)

(4)

(4)

0.038

0.15

0.037

0.5

0.05

(7)

(8)

(8)

(i)

0.08

.01
3.

1.

(4)

8.

2.

(4)

1 Values expressed as mean, S.E.M., (number of animals per group). HF generated by compressed gas technique. Exposure started at time 0 . All rats sacrificed on 15th day of fluoride depletion.

a $p<0.05$ compared to control.

b $\quad p<0.01$ compared to control. 
evidence that any excess fluoride reached the lungs of these rats via the airways, i.e. that airborne HF penetrated to the lung. The total and ionic lung fluoride concentrations in the lungs of rats sacrificed at 7 hours or later were not higher than control levels. Thus, no long term retention of fluoride in the lungs of nose-only exposed rats was detected. Similarly, no long term retention of fluoride in the kidneys of these rats was detected, kidney fluoride concentrations having returned to control levels by 12 hours. Plasma ionic fluoride concentrations decreased with succeeding sacrifice times. Plasma ionic fluoride concentrations were significantly higher than control levels in rats sacrificed at 24 hours, but not in rats sacrificed at 96 hours .

The total fluoride concentration in trachea increased with time after HF exposure. Mean tracheal fluoride concentration was actually less than control levels in rats sacrificed immediately after HF exposure indicating that the increased fluoride concentrations in this tissue following exposure were not due to airborne HF which deposited at this site. The mechanism(s) influencing tracheal fluoride concentrations are unclear. $\Delta F$ concentrations in soft tissues of rats following nose-only HF exposure were variable and in some cases less than control levels (Table 65). The concentration of $\Delta F$ in lung, plasma and kidney of exposed rats was significantly higher than control levels immediately following exposure, but was not elevated at any other sacrifice time. 
TABLE 65

$\triangle F$ CONCENTRATIONS IN SOFT TISSUES OF RATS AFTER NOSE-ONLY EXPOSURE TO APPROXIMATELY $63 \mathrm{mg} \mathrm{F} / \mathrm{m}^{3} \mathrm{HF}$ FOR 1 HOUR 1

\section{Sacrifice}

time

HF Exposed

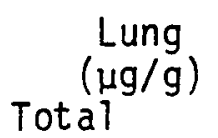

\section{Plasma}

$(\mu \mathrm{g} / \mathrm{mT})$
Kidney

$(\mu \mathrm{g} / \mathrm{g})$

\begin{tabular}{|c|c|c|c|c|c|}
\hline 1 hour & $\begin{array}{l}1.3 \\
.1 \\
(4)\end{array}$ & $\begin{array}{l}1.1^{b} \\
(4)^{1}\end{array}$ & $\begin{array}{r}0.59 \\
10 \\
(4)\end{array}$ & $\begin{array}{c}0.32^{b} \\
.08 \\
(4)\end{array}$ & $\begin{array}{l}1.9 \\
.2 \\
(4)\end{array}$ \\
\hline 7 hour & $\begin{array}{l}0.6 \\
(1) \\
(4)\end{array}$ & $\begin{array}{l}0.5 \\
.1 \\
(4)\end{array}$ & $\begin{array}{r}0.14 \\
.01 \\
(4)\end{array}$ & $\begin{array}{c}0.06^{\mathrm{a}} \\
.01 \\
(4)\end{array}$ & $\begin{array}{l}0.8 \\
(4)\end{array}$ \\
\hline 12 hour & $\begin{array}{l}0.4 \\
.1 \\
(3)\end{array}$ & $\begin{array}{l}0.4 \\
.1 \\
(3)\end{array}$ & $\begin{array}{r}0.09 \\
.01 \\
(3)\end{array}$ & $\begin{array}{c}0.03 b \\
.00 \\
(3)\end{array}$ & $\begin{array}{l}0.3 \\
(3)\end{array}$ \\
\hline 24 hour & $\begin{array}{l}0.4 \\
.1 \\
(3)\end{array}$ & $\begin{array}{l}0.4 \\
.1 \\
(3)\end{array}$ & $\begin{array}{r}0.08 \\
.01 \\
(3)\end{array}$ & $\begin{array}{c}0.03^{b} \\
.00 \\
(3)\end{array}$ & $\begin{array}{l}0.3 \\
.0 \\
(3)\end{array}$ \\
\hline 96 hour & $\begin{array}{l}0.4 \\
.1 \\
(3)\end{array}$ & $\begin{array}{l}0.4 \\
.1 \\
(3)\end{array}$ & $\begin{array}{r}0.08 \\
.01 \\
(3)\end{array}$ & $\begin{array}{c}0.03^{b} \\
.00 \\
(3)\end{array}$ & $\begin{array}{l}0.3 \\
.0 \\
(3)\end{array}$ \\
\hline Control & $\begin{array}{l}0.7 \\
(7)\end{array}$ & $\begin{array}{l}0.6 \\
\dot{1} \overline{7})\end{array}$ & $\begin{array}{r}0.15 \\
02 \\
(8)\end{array}$ & $\begin{array}{r}0.11 \\
.02 \\
(8)\end{array}$ & $\begin{array}{l}0.5 \\
(7)\end{array}$ \\
\hline
\end{tabular}

1 Values expressed as mean, S.E.M., (number of animals per group). HF generated by compressed gas technique. Exposure started at time 0 . All rats sacrificed on 15th day of fluoride depletion.

a $p<0.05$ compared to control.

b $\quad p<0.01$ compared to control. 
Exposure to HF resulted in a prompt increase and then decrease in urinary fluoride excretion (Table 66). Since all rats were sacrificed during the 15th day on the low $F$ regimen, the urinary fluoride excretion in exposed rats from $48-72$ hours should be compared with the control value from $0-24$ hours, both groups having been on the low $F$ regimen for 14 days. Similarly, the control values for 24-48 hours and the exposed values for 72-96 hours are from rats which had been maintained or the low $F$ regimen for 15 days. This confusing situation is due to an error. The wrong group of fluoride depleted rats was subjected to the control exposure and had to be sacrificed at 48 hours instead of at 96 hours as originally intended. The urinary fluoride excretion 48-72 and 72-96 hours after the start of the 1 hour nose-only HF exposure was not higher than control levels. The bladder urine in rats sacrificed immediately following HF exposure contained an average of $7.3 \mu \mathrm{g}$ of fluoride. A control amount of approximately $1 \mathrm{\mu g}$ can be estimated (1/7th of the $0-7$ hour control value, $1 / 24$ th of the 0-24 or 24-48 hour value), suggesting an excess of $6.3 \mu \mathrm{g}$ fluoride in HF exposed rats. This value is approximately 28 of the estimated inhaled fluoride dose of $378 \mu \mathrm{g}$ fluoride. The inhaled fluoride dose was estimated assuming a ventilation rate of 0.1 $1 / \min$ fori the anaestheslzed rat and an airborne concentration of 63 $\mathrm{mg} \mathrm{F} / \mathrm{m}^{3}$. Fluoride excretion by exposed rats was 16 -fold higher during the 0-7 hour period than in control rats. The rats sacrificed at 12 hours excreted a mean of $78 \mu \mathrm{g}$ during the $0-7$ hour period (Table 6I). An addiliunal $20 \mu \mathrm{y}$ fluorlde was 
TABLE 66

URINARY IONIC FLUORIDE EXCRETION, FECAL TOTAL FLUORIDE CONCENTRATION ANC FEMORAL FLUORIDE CONTENT FOLLOWING NOSE-ONLY EXPOSURE TO $63 \mathrm{mg} \mathrm{F} / \mathrm{m}^{3}$ HF FOR 1 HOUR 1

\begin{tabular}{|c|c|c|c|c|c|c|}
\hline \multirow{2}{*}{$\begin{array}{l}\text { Collection } \\
\text { period }\end{array}$} & \multicolumn{2}{|c|}{$\begin{array}{l}\text { Urinary Ionic F- } \\
(\mu \mathrm{g} / \text { period })\end{array}$} & \multicolumn{2}{|c|}{$\begin{array}{c}\text { Fecal Total } F \\
(\mu g / g)\end{array}$} & \multicolumn{2}{|c|}{$\underset{(\mu g)}{\text { Femoral Total } F^{3}}$} \\
\hline & Exposed & Control & Exposed & Control & Exposed & Control \\
\hline $0-1$ hour & $\begin{array}{l}7.3 \\
2.2 \\
(4)\end{array}$ & & & & $\begin{array}{r}112 \\
7 \\
(4)\end{array}$ & \\
\hline $0-?$ hour & $\begin{array}{c}1.05^{b} \\
9 \\
(4)\end{array}$ & $\begin{array}{l}6.6 \\
.5 \\
\text { (7) }\end{array}$ & & & $\begin{array}{r}126 \\
10 \\
(4)\end{array}$ & $\begin{array}{r}108 \\
7 \\
(3)\end{array}$ \\
\hline $0-12$ hour & $\begin{array}{l}98^{b} \\
11 \\
(3)^{b}\end{array}$ & & 0.1 & & $\begin{array}{r}153 \\
14 \\
(3)\end{array}$ & \\
\hline $0-24$ hour & $\begin{array}{l}186^{b} \\
13 \\
(7)\end{array}$ & $\begin{array}{r}22 \\
2 \\
(4)\end{array}$ & $\begin{array}{l}7.9 \\
1.1 \\
(6)\end{array}$ & $\begin{array}{l}1.6^{2} \\
(\dot{8})\end{array}$ & $\begin{array}{r}139 \\
2 \\
(3)^{2}\end{array}$ & \\
\hline $24-\angle 8$ hcur & $\begin{array}{c}34^{b} \\
1 \\
(4)^{2}\end{array}$ & $\begin{array}{r}17 \\
1 \\
(4)\end{array}$ & $\begin{array}{l}6.9 \\
1.8 \\
(4)\end{array}$ & & & $\begin{array}{r}136 \\
9 \\
(4)\end{array}$ \\
\hline $48-i 2$ hcur & $\begin{array}{r}21 \\
2 \\
(4)^{2}\end{array}$ & & $\begin{array}{l}5.9 \\
1.1 \\
(4)\end{array}$ & & & \\
\hline $72-\subseteq 6$ hour & $\begin{array}{r}19 \\
1 \\
(4)\end{array}$ & & $\begin{array}{r}3.7 \\
.7 \\
(4)\end{array}$ & & $\begin{array}{r}121 \\
8 \\
(4)\end{array}$ & \\
\hline
\end{tabular}


URINARY IONIC FLUORIDE EXCRETION, FECAL TOTAL FLUORIDE CONCENTRATION AN FEMORAL FLUORIDE CONTENT FOLLOWING NOSE-ONLY EXPOSURE TO $63 \mathrm{mg} \mathrm{F} / \mathrm{m}^{3}$ HF FOR 1 HOUR 1

1 Values expressed as mean, S.E.M., (number of animais per group). HF atmospheres generated by compressed gas technique. Exposure started at time 0 . All rats were sacrificed on the 15 th day of fluoride depletion.

2 This is the value for the entire group. Feces were collected from $0-24$ and 24-48 hours in control rats.

3 Fluoride content was determined on the femurs of rats sacrificed at the end of the collection periods.

b $\quad p<0.01$ compared to control. 
excreted during the 7-12 hour period. Urinary fluoride excretion during the 0-24 hour and 24-48 hour period was significantly elevated by HF exposure. Exposed rats excreted a mean of $12 \mu \mathrm{g}$ more fluoride during the 24-48 hour period than control rats during the 0-24 hour period. Some of this difference may have been due to the fact that this time period occurred on the 13th day of fluoride depletion in exposed rats compared to the 14 th day for control rats. Thus, the $12 \mu \mathrm{g}$ represents a maximal value for the excess fluoride excretion during the 24-48 hour period.

The excess urinary fluoride excretion in HF exposed rats averaged $176 \mu \mathrm{g}$. Division of this value by $22 \%$ results in an estimated absorbed fluoride dose of $800 \mu \mathrm{g}$. As previously discussed the estimated amount of fluoride inhaled during the exposure was $378 \mu \mathrm{g}$. Thus, even nose-only exposed rats appear to have a source of fluoride other than inhalation. The magnitude of this source appears, however, to be much less than in whole body exposed rats. As will be shown below nose-only exposure to $\mathrm{HF}$ resulted in the deposition of large amounts of fluoride on the fur surrounding the nose.

The fecal total fluoride concentration was significantly elevated by exposure to HF (Table 66). The mean fluoride concentration in feces of exposed rats excreted during the 72-96 hour perlod was higher than control levels but not significantly so. The femoral fluoride content in the 7 control rats averaged 124 $\pm 8 \mu \mathrm{g}$ (mean \pm SEM) (Table 66). The fluoride content of femurs from exposed iats tended to be higher than this control amount but 
not significantly so. The femoral fluoride in exposed rats sacriticed at 12 hours or later averaged $136 \pm 6 \mu \mathrm{g}$ (mean $\pm \mathrm{SEM}$ ).

Urine samples for each collection period were pooled by exposure group and ashed for determination of total fluoride concentration. $\Delta F$ appeared to be present in the urine of control rats (Table 67). $\Delta F$ also appeared to be present in urine of exposed rats, but not in higher concentrations than in control urine.

The upper respiratory tract of nose-only exposed rats was rinsed three times with $4 \mathrm{ml}$ of double distilled water. Approximately 1000-fold more fluoride was removed from the upper respiratory tract of rats immediately after exposure to HF than from control rats (Table 68). The only procedures performed on the rats exposed to $73-79 \mathrm{mg} \mathrm{F} / \mathrm{m}^{3}$ and sacrificed at 1 and 7 hours were the upper respiratory tract rinse procedure, and wiping and removal of the pelt around the nose. All other data reported for these sacrifice times were obtained from rats exposed to $57-68 \mathrm{mg}$ $\mathrm{F} / \mathrm{m}^{3} \mathrm{HF}$. The slight difference in exposure concentrations between these groups of rats is assumed to be of no significance. Successive rinses of the upper respiratory tract did not remove lesser amounts of fluoride indicating that rinsing is not a quantitative extraction procedure. Fluoride in excess of control levels were removed fram the upper respiratory tract of HF exposed animals sacrificed as late as 24 hours suggesting that clearance of fluoride from this site was not complete by this time. 
TABLE 67

$\triangle F$ CONCENTRATION IN URINE OF RATS AFTER

NOSE-ONLY EXPOSURE TO APPROXIMATELY

$63 \mathrm{mg} \mathrm{F} / \mathrm{m}^{3}$ HF FOR 1 HOUR 1

Collection

period

HF Exposed

Urinary fluoride concentration

Total $(\mu \mathrm{g} / \mathrm{ml})$ Ionic

\section{Exposed}

$0-7$

10.5

10.7

11.2

7.1

9.38

9.63

11.3

6.36

0.9

0.4

$-0.1$

0.7

7-12

4.1

4.01

$-0.1$

7-24

4.0

4.25

2.12

$-0.3$

2.2

1.76

0.3

24-48

2.1

1.26

0.1

72-96

1.4

1.11

0.3

Control

$\begin{array}{rrrr}0-7 & 1.4 & 0.61 & 0.8 \\ 7-24 & 1.1 & .76 & 0.3 \\ 24-48 & 1.3 & .92 & 0.4 \\ & 1.0 & .76 & 0.2\end{array}$

1 Urines were pooled by exposure group. The concentration measured in each. pool is given. Concentration not corrected for cage wash water. HF generated by compressed gased technique. Exposure started at time 0 . All rats sacrificed on the 15th day of fluoride depletion. 


\section{TABLE 68}

FLUORIDE CONCENTRATIONS IN UPPER RESPIRATORY TRACT RINSES OF RATS EXPOSED TO APPROXIMATELY

$63 \mathrm{mg} \mathrm{F} / \mathrm{m}^{3}$ HF FOR 1 HOUR 1

\begin{tabular}{|c|c|c|c|c|c|c|}
\hline lirborne HF & $\begin{array}{l}\text { Sacrifice } \\
\text { time }\end{array}$ & $\begin{array}{l}\text { Ionic } F- \\
\frac{1 s t}{(\mu g)}\end{array}$ & $\begin{array}{l}\text { emoved } \\
\qquad \frac{2 \text { nd }}{(\mu \mathrm{g})}\end{array}$ & $\begin{array}{l}r \text { rinse } \\
\frac{3 r d}{(\mu g)}\end{array}$ & $\begin{array}{l}\text { Cumul at ive } \\
\text { Ionic F- } \\
(\mu \mathrm{g})\end{array}$ & $\begin{array}{c}\text { Cumulative }{ }^{3} \\
\text { Total } F \\
(\mu g)\end{array}$ \\
\hline $\begin{array}{l}73 \\
77 \\
79\end{array}$ & $\begin{array}{ll}1 & \mathrm{hr} . \\
1 & \mathrm{hr} . \\
1 & \mathrm{hr} .\end{array}$ & $\begin{array}{l}14 \\
28 \\
13\end{array}$ & $\begin{array}{r}28 \\
6 \\
12\end{array}$ & $\begin{array}{r}8 \\
11 \\
10\end{array}$ & $\begin{array}{l}46 \\
45 \\
35\end{array}$ & $\begin{array}{l}45 \\
53 \\
41\end{array}$ \\
\hline $\begin{array}{l}73 \\
73 \\
77\end{array}$ & $\begin{array}{l}7 \mathrm{hr} . \\
7 \mathrm{hr} . \\
7 \mathrm{hr} .\end{array}$ & $\begin{array}{r}0.26 \\
.33 \\
.94\end{array}$ & $\begin{array}{r}0.21 \\
.32 \\
.38\end{array}$ & $\begin{array}{r}0.20 \\
.30 \\
.19\end{array}$ & $\begin{array}{r}.67 \\
.95 \\
1.51\end{array}$ & $\begin{array}{l}0.7 \\
2.1 \\
0.8\end{array}$ \\
\hline $\begin{array}{l}68 \\
68 \\
68\end{array}$ & $\begin{array}{l}12 \mathrm{hr} . \\
12 \mathrm{hr} . \\
12 \mathrm{hr} .\end{array}$ & $\begin{array}{r}0.22 \\
.34 \\
.60\end{array}$ & $\begin{array}{r}0.30 \\
.19 \\
.76\end{array}$ & $\begin{array}{r}0.39 \\
.21 \\
.44\end{array}$ & $\begin{array}{r}.91 \\
.74 \\
1.80\end{array}$ & $\begin{array}{l}0.2 \\
0.7 \\
0.9\end{array}$ \\
\hline $\begin{array}{l}68 \\
68 \\
68\end{array}$ & $\begin{array}{l}24 \mathrm{hr} . \\
24 \mathrm{hr} . \\
24 \mathrm{hr} .\end{array}$ & $\begin{array}{r}0.05 \\
. \quad .06 \\
.05\end{array}$ & $\begin{array}{r}0.20 \\
.05 \\
.04\end{array}$ & $\begin{array}{r}0.15 \\
.12 \\
.07\end{array}$ & $\begin{array}{r}0.40 \\
.23 \\
.16\end{array}$ & $0.2^{4}$ \\
\hline $\begin{array}{l}68 \\
68 \\
68\end{array}$ & $\begin{array}{l}96 \mathrm{hr} . \\
96 \mathrm{hr} . \\
96 \mathrm{hr} .\end{array}$ & $\begin{array}{r}J .02 \\
.02 \\
.01\end{array}$ & $\begin{array}{r}0.01 \\
.01 \\
.01\end{array}$ & $\begin{array}{r}0.01 \\
.01 \\
.01\end{array}$ & $\begin{array}{r}0.04 \\
.04 \\
.03\end{array}$ & $0.0^{4}$ \\
\hline $\begin{array}{l}\text { Control } \\
\text { Control } \\
\text { Control } \\
\text { Control }\end{array}$ & & $\begin{array}{r}0.03 \\
.02 \\
.01 \\
.02\end{array}$ & $\begin{array}{r}0.01 \\
.02 \\
.01 \\
.01\end{array}$ & $\begin{array}{r}0.01 \\
.01 \\
.01 \\
.02\end{array}$ & $\begin{array}{r}0.05 \\
.05 \\
.03 \\
.05\end{array}$ & $0.0^{4}$ \\
\hline
\end{tabular}




\section{TABLE 68 (Footnotes)}

\section{FLUORIDE CONCENTRATIONS IN UPPER RESPIRATORY TRACT}

RINSES OF RATS EXPOSED TO APPROXIMATELY

$63 \mathrm{mg} \mathrm{F} / \mathrm{m}^{3}$ HF FOR 1 HOUR ${ }^{1}$

1 Individual values are reported. HF generated by compressed gas technique. Exposure started at time 0 . All rats sacrificed on 15 th day of fluoride depletion.

2 Upper respiratory tract subjected to 3 consecutive rinses.

3 The three rinses from each rat were pooled prior to ashing for determination of the clmulative total fluoride removed.

4 The three rinses from every rat per group were pooled prior to ashing for determination of cumulative total fluoride removed. 
Equal volumes of each of the three rinses from each rat sacrificed at 1,7 and 12 hours were pooled by $r$ at and ashed for determination of total fluoride content. The rinses of control rats and exposed rats sacrificed at 24 and 96 hours were pooled by group. Significant levels of $\Delta F$ were not detected in the upper respiratory tract rinses.

The fur covering the nose of control and HF exposed rats sacrificed at 1,7 and 12 hours was wiped twice with two moist gauzes, to determine how much fluoride could be easily removed from this site. Significantly more fluoride could be removed from the fur of exposed rats than from that of controls (Table 69). After wiping, the pelt around the nose was removed and ashed for determination of fluoride content. Large amounts of fluoride were left behind on the fur after the wiping procedure. At 1 hour approximately 508 of the fluoride in the pelt could be removed by this procedure. Only 148 could be removed at 7 hours. If 148 of the fluoride present on the fur at 12 hours could be removed by this wiping procedure it can be estimated that $30 \mu \mathrm{g}$ of fluoride was present on the pelt at 12 hours. Immediately after exposure an average of $370 \mu \mathrm{g}$ of fluoride was present in the pelt. Only 80 $\mu \mathrm{g}$ was present in the pelt at 7 hours suggesting that significant amounts of fluoride had been removed during the 1-7 hour postexposure period. It is interesting to note that the sum of the fluoride on the fur immediately after exposure $(370 \mu \mathrm{g})$ and the estimated amount of fluoride inhaled during the exposure $(378 \mu \mathrm{g})$ 
TABLE 69

FLUORIDE ON FUR OF RATS AFTER NOSE-ONLY EXPOSURE TO APPROXIMATELY $63 \mathrm{mg} \mathrm{F} / \mathrm{m}^{3} \mathrm{HF}$ FOR 1 HOUR 1

\begin{tabular}{|c|c|c|c|c|c|c|c|}
\hline $\begin{array}{l}\text { Airborne } \\
\quad H F \\
(\mathrm{mg} / \mathrm{m} 3)\end{array}$ & $\begin{array}{l}\text { Sacrifice } \\
\text { time }\end{array}$ & $\begin{array}{l}\text { Fluoride } \\
\text { Ist } \\
\text { Ionic } \\
\text { ( } \mu \mathrm{g})\end{array}$ & $\begin{array}{c}\text { removed } \\
2_{\text {Iond }}^{\text {nd }} \\
(\mu g)\end{array}$ & $\begin{array}{l}\text { by nose } \\
\text { Cumu } \\
\text { Ionic } \\
(\mu \mathrm{g})\end{array}$ & $\begin{array}{l}\text { wipe2 } \\
\text { at ive } \\
\text { Total } \\
\text { ( } \mu g)\end{array}$ & $\begin{array}{c}\text { Fluoride remaining } \\
\text { on fur } \\
\text { Total } \\
(\mu g)\end{array}$ & $\begin{array}{l}F \text { deposited } \\
\text { on fur }{ }^{3} \\
\text { Total } \\
(\mu g)\end{array}$ \\
\hline $\begin{array}{l}73 \\
77 \\
79\end{array}$ & $\begin{array}{ll}1 & \mathrm{hr} . \\
1 & \mathrm{hr} . \\
1 & \mathrm{hr} .\end{array}$ & $\begin{array}{r}113 \\
88 \\
101\end{array}$ & $\begin{array}{l}60 \\
63 \\
69\end{array}$ & $\begin{array}{l}176 \\
151 \\
170\end{array}$ & $\begin{array}{l}1.72 \\
186 \\
156\end{array}$ & $\begin{array}{l}169 \\
318 \\
105\end{array}$ & $\begin{array}{l}341 \\
504 \\
261\end{array}$ \\
\hline $\begin{array}{l}73 \\
73 \\
77\end{array}$ & $\begin{array}{l}7 \mathrm{hr} . \\
7 \mathrm{hr} . \\
7 \mathrm{hr} .\end{array}$ & $\begin{array}{l}8.2 \\
6.2 \\
4.5\end{array}$ & $\begin{array}{l}7.2 \\
4.3 \\
4.5\end{array}$ & $\begin{array}{r}15.4 \\
10.5 \\
9.0\end{array}$ & $\begin{array}{r}11 . \\
6 . \\
8 .\end{array}$ & $\begin{array}{l}79 \\
67 \\
66\end{array}$ & $\begin{array}{l}90 \\
73 \\
74\end{array}$ \\
\hline $\begin{array}{l}68 \\
68 \\
68\end{array}$ & $\begin{array}{l}12 \mathrm{hr} . \\
12 \mathrm{hr} . \\
12 \mathrm{hr} .\end{array}$ & $\begin{array}{l}1.7 \\
1.1 \\
4.2\end{array}$ & $\begin{array}{l}2.9 \\
0.9 \\
1.9\end{array}$ & $\begin{array}{l}4.6 \\
2.0 \\
6.1\end{array}$ & $\begin{array}{l}3 . \\
2 . \\
4 .\end{array}$ & & \\
\hline $\begin{array}{l}\text { Contral } \\
\text { Contral } \\
\text { Control }\end{array}$ & & $\begin{array}{l}.11 \\
.04 \\
.09\end{array}$ & $\begin{array}{l}.06 \\
.08 \\
.04\end{array}$ & $\begin{array}{l}.17 \\
.12 \\
.13\end{array}$ & 0.4 & $\begin{array}{l}1.0 \\
0.9 \\
0.0\end{array}$ & \\
\hline
\end{tabular}




\section{TABLE 69 (Footnotes)}

FLUORIDE ON FUR OF RATS AFTER NOSE-ONLY

EXPOSURE TO APPROXIMATELY

$63 \mathrm{mg} \mathrm{F} / \mathrm{m}^{3}$ HF FOR 1 HOUR 1

1 Individual values are reported. HF generated by compressed gas technique. Exposures started at time 0 . All rats were sacrificed on the 15 th day of fluoride depletion.

2 The fur covering the nose was wiped twice with a wet gauze. The cumulative is the sum of that removed by the two wipes. The two wipes were pooled prior to ashing for determination of cumulative total fluoride removed.

3 Calculated as sum of cumulative total fluoride removed by wipe procedure and total fluoride remaining.

4 Hipes from all control animals were pooled prior to ashing for determination of cumulative total fluoride removed. 
is close to the absorbed fluoride dose estimated from the urinary fluoride excretion to be $800 \mu \mathrm{g}$.

G. Control Data

In the course of all the experiments described in this thesis 94 control rats on normal $F$ diet and 11 fluoride depleted control rats were sacrificed. In this section the data from these control animals are compiled to determine if any trends are evident.

The fluoride concentrations in soft tissues and the frequency of occurrence of positive, negative and zero $\Delta F$ concentrations in these control rats are given in Table 70 . There are more ionic fluoride values than total or $\Delta F$ values because many tissues were pooled for detemination of total fluoride after ionic fluoride concentration had been determined. The control group for $380 \mathrm{mg}$ $\mathrm{F} / \mathrm{m}^{3}$ preliminary experiment exposure are not included in this section because of their prior exposure to $8.3 \mathrm{mg} \mathrm{F} / \mathrm{m}^{3}$ HF for 75 minutes. In all of these tissues, lung, plasma and kidney, total fluoride concentration was significantly higher than ionic fluoride concentration suggesting that $\Delta F$ was present in control tissues. In all tissues, the levels of $\Delta F$ were at the limit of sensitivity of the analytical methods employed. The concentration of $\Delta F$ was apparently unaffected by fluoride depletion, however, in all cases the levels of $\Delta F$ are so low that no real comparisons can be made. With the exception of the kidney in fluoride depleted rats, the frequency of occurrence of positive $\Delta F$ concentrations in the soft tissues of both normal $F$ diet and fluoride depleted rats was much higher than would be expected on the basis of random 
TABLE 70

FLUORIDE CONCENTRATION IN SOFT TISSUES OF CONTROL RATS1

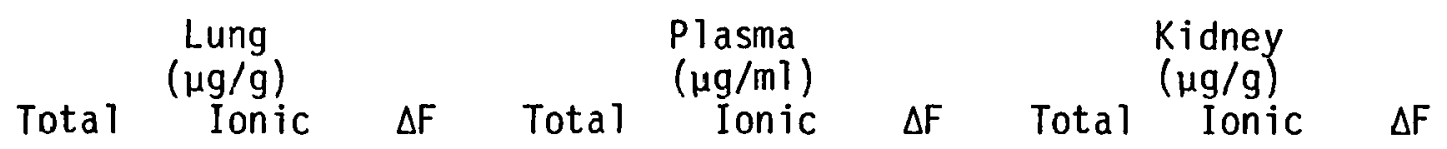

\section{Normal F diet}

$\begin{array}{rr}0.5 & 0.06 \\ (25) & (30) \\ 0 & \\ 0 & 23 \\ 0 & 1 \\ & \\ & <0.01\end{array}$

$0.4-0.10=0.000$

.

number of samples with $\Delta F>0$

$$
p \text { value (sign test) } \begin{aligned}
\Delta F=0 \\
\Delta F<0
\end{aligned}
$$

\section{F depleted}

$\begin{array}{rrrrrrrrr}0.6 & 0.05 & 0.5 & 0.12 & 0.029 & 0.09 & 0.4 & 0.05 & 0.3 \\ 0.1 & .01 & .1 & .02 & .004 & .02 & 0.1 & .01 & .1 \\ (10) & (10) & (10) & (11) & (11) & (11) & (10) & (10) & (10)\end{array}$

number of samples with $\Delta \mathrm{F}>0$

$$
p \text { value (sign test) } \begin{gathered}
\Delta F=0 \\
\Delta F<0
\end{gathered}
$$

1 Values expressed as mean, S.E.M., (number of animals per group).

10
0
0
$<0.01$

11
0
0
$<0.01$

8
1
1
$<0.10$ 
analytical error. No trend toward increasing or decreasing total ionic, or $\Delta F$ concentrations was noticed with increasing body weight suggesting that fluoride does not accumulate in these tissues with age.

When total femoral fluoride content is plotted against body weight (Figure 27) a strong correlation is evident ( $r=$ $0.87, \mathrm{df}=39, \mathrm{p}<0.01)$ suggesting that fluoride accumulates in the skeleton with age.

$\Delta F$ was not detected in pooled urine samples from normal $F$ diet control rats (Table 71). Not only was the mean $\Delta F$ concentration equal to 0.0 but equal numbers of positive and negative $\Delta F$ concentrations were obtained. Significant levels of $\Delta F$ were detected in the urine excreted by fluoride depleted rats during the 11th through 15th day of fluoride depletion. The mean $\Delta F$ concentration in urine of fluoride depleted rats was statistically higher $(p<0.05)$ than that in urine of normal $F$ diet rats. This may represent a real difference, or the lowered ionic fluoride concentrations in the urine of fluoride depleted rats may have merely unmasked the presence of a $\Delta F$ fraction which was always present. 
FIGURE 27

Total femoral fluoride content of control rats vs body weight. The linear regression 1 ine is shown $(f=.87$, df $=39, p<.01)$. 


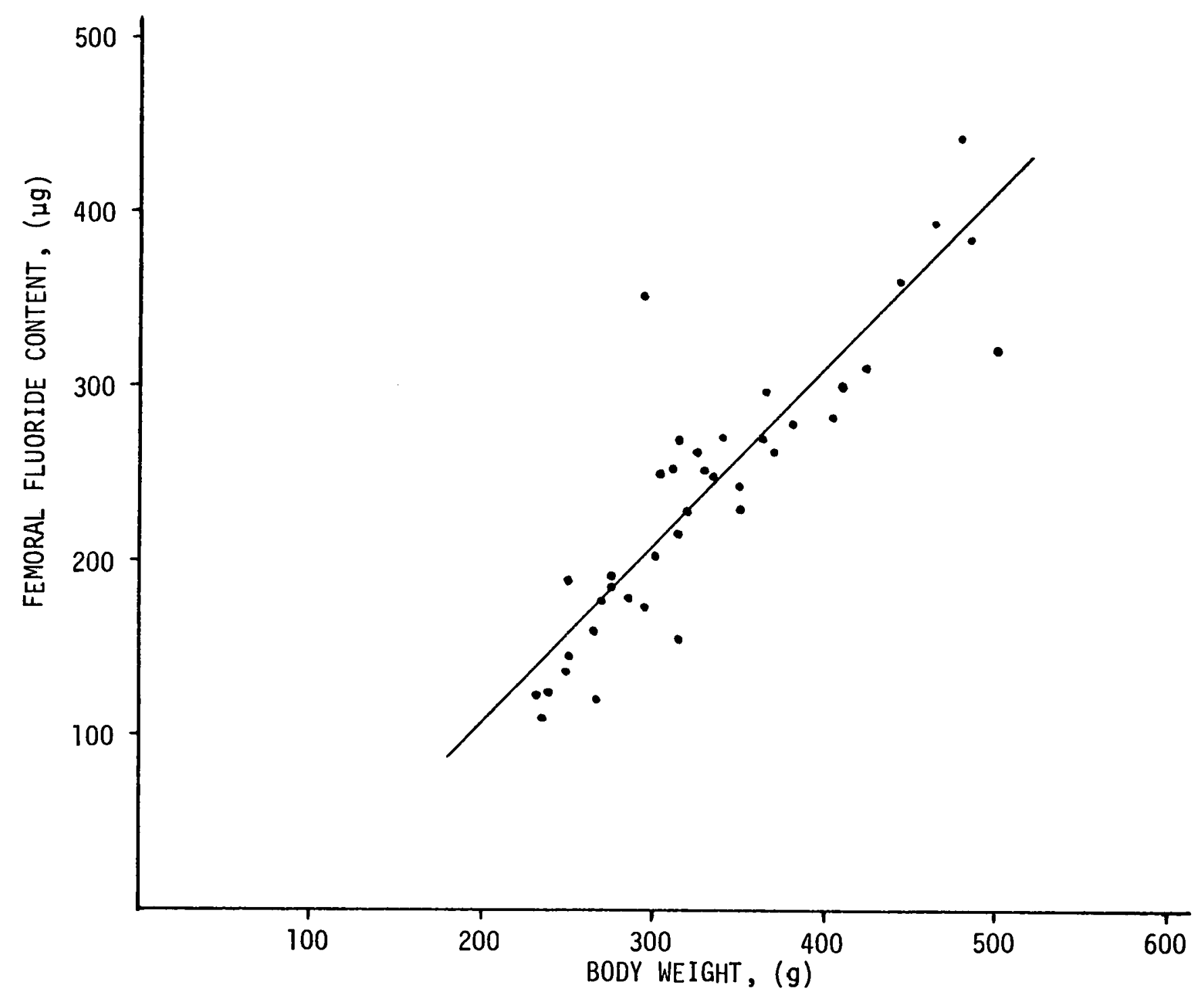




\section{TABLE 71}

$\triangle F$ CONCENTRATIONS IN URINE OF CONTROL RATSI

Fluoride concentration ${ }^{2}$ Number of samples with

Total ( $\begin{gathered}\text { Ionic } \\ \text { To }\end{gathered}$




\section{DISCUSS ION}

Fluoride is ubiquitous in our environment. This halogen is the thirteenth most abundant element on earth. Fluoride has also been detected in metorites (Reed, 1964) and in lunar samples (Reed, et al., 1970). Hydrogen fluoride is present in the atmosphere of Venus (Mueller, 1968). On earth fluoride is present in sea water and in small amounts in most fresh water. The average fluoride concentration in the tap water consumed by the rats used in these investigations was $1.0 \mu \mathrm{g} / \mathrm{ml}$. The fluoride concentration in Purina rat chow ranged between 25 and $35 \mu \mathrm{g} / \mathrm{g}$. That significant amounts of this dietary fluoride is absorbed by these rats is shown by the presence of fluoride in soft tissues, skeleton and urine. All fluoride concentrations in this study were determined with the fluoride ion sensitive electrode (Frant and Ross, 1966). The voluminous literature concerning the metabolism of the fluoride ion has been reviewed by Smith (1966). In general this ion is thought to be rapidly absorbed and distributed throughout all the tissues in the body after ingestion. Absorbed fluoride deposits in the skeleton and is excreted rapidly in the urine. Fluoride is not thought to accumulate in any soft tissue, except in sites of ectopic calcification (Ericsson and Ullberg, 1958). In the rat absorption of fluoride through the gastrointestinal tract is quite rapid. Absorption of a small dose of fluoride $(200 \mu \mathrm{g} \mathrm{F})$ from this site has been reported to be 508 complete in 30 minutes and 868 complete by 90 minutes (zipkin and 
Lipkins, 1957). Large doses of fluoride are absorbed efficiently as well, 958 absorption of a $1.0-2.0 \mathrm{mg}$ dose occurring within 24 hours after intubation (de Lopez, et al., 1976).

Fluoride is readily permeable to biologic membranes. In an in vitro experiment, fluoride ion added to whole blood equilibrated within the red blood cells within two minutes, the time point of the first sample collection (Carlson, et al., 1960a). Within 15 minutes, again the first time point, after intravenous injection of $\mathrm{Na}^{18} \mathrm{~F}$ solution ${ }^{18} \mathrm{~F}$ activity was detected in every soft tissue analyzed (Wallace-Durbin, 1954).

Once absorbed the fluoride ion rapidly deposits in the skeleton. Using autoradiographic techniques Ericsson and Ullberg (1958) demonstrated marked skeletal fluoride deposition in the mouse 2 minutes after intravenous $\mathrm{Na}^{18} \mathrm{~F}$ injection. In the rat 338 of an intravenous $\mathrm{Na}^{18} \mathrm{~F}$ injection was present in the skeleton 15 minutes after injection (Wallace-Durbin, 1954). In this same study 48.5 568 of the fluoride dose was present in the skeleton 1-9 hours after injection. In the rabbit approximately 658 of an intravenous dose of $\mathrm{Na}^{18} \mathrm{~F}$ was deposited in the skeleton within 75 minutes (Hall, et al., 1977). Several studies have shown that the fraction of an acute fluoride dose deposited in the skeleton is independent of the dose. In the rat similar percentages of an intravenous ${ }^{18_{F}}$ dose were deposited in the skeleton after injection of $0.15 \mu \mathrm{g}$ or $1.85 \mathrm{mg} \mathrm{F}$ (Wallace-Durbin, 1954). In the studies of the kinetics of fluoride metabolism in the rabbit Hall et al. (1977) the levels of ${ }^{18} \mathrm{~F}$ present in the skeleton and urine after injection of carrier 
free ${ }^{18} \mathrm{~F}$ agreed well with the levels predicted from data obtained after injection of $0.5 \mathrm{mg} / \mathrm{kg} \mathrm{F}$. Ericsson (1966) has shown that the fraction of administered fluoride deposited in the skeleton of rats after a single acute dose of $\mathrm{Na}^{18} \mathrm{~F}$ was not affected by the previous dietary fluoride intake.

Once deposited in skeletal tissue fluoride is removed slowly. The skeletons of rats sacrificed 150 days after the end of a 60 day feeding study contained $85 \%$ of the amount of fluoride present in this site immediately after the feeding period (Savchuck and Armstrong, 1951). Ophaug and Singer (1977) found only 158 of the fluoride accumulated in the skeleton of rats during a feeding experiment to be removed during a 28 day post-exposure period. These studies indicate that a small portion of the fluoride deposited in the skeleton may be removed relatively quickly after a reduction in fluoride intake but the major fraction of fluoride sequestered in the skeleton remains in that site for long periods of time. Since fluoride deposits rapidly in skeletal tissue and is removed slowly, the halogen should accumulate in that site. The strong correlation of femoral fluoride content and body weight in control rats sacrificed in these studies suggests such an accumulation is occurring. A similar relationship between bone fluoride content and age in humans has been reported by Smith (1966). In the present studies instead of determining the fluoride content in the entire skeleton, the femur was used as a representative sample. Savchuck and Armstrong (1954) reported the femora to account for 9.38 of the rat skeletal ash weight and 
contain 8.8 - 10.28 of the total skeletal fluoride content, indicating the appropriateness of the femur as a representative sample of the skeleton.

In addition to depositing in bone the fluoride ion is excreted in the urine. In the dog fluoride appears to filtered in the glomerulus and then partially reabsorbed (Carlson, et al., 1960b). Fluoride reabsorption ranged between 23-798 of that filtered. Fluoride clearance was always less than creatine clearance but many fold greater, in one case 230 fold greater, than chloride clearance. The large different between fluoride and chloride clearance may suggest that the kidney can discriminate between these two halogens.

Renal excretion of fluoride is quite rapid. In the present studies $6 \%$ of the fluoride infused intravenously was present in the urine at the end of the 1 hour infusion. In a 6 hour period after the end of infusion 198 of the infused dose was excreted in the urine. After intraperitonieal or intratracheal injection $22 \pm 58$ (mean \pm std. dev.) of the administered dose was excreted in the urine of rats within 24 hours. Elevations in urinary fluoride excretion were not detected $24-48$ hours after injection. If 58 of the injected dose were to be excreted during this period, in all probability it would have been detected. In human subjects 548 and 488 of an ingested fluoride dose was excreted in the urine in 24 hours (Zipkin and Leone, 1957; Hennon, et al., 1969). Hall, et al. (1977) found $20 \%$ of an intravenous dose of fluoride to be excreted in the urine by the rabbit within 9 hours. In the rat 108 and 318 of 
intravenously injected fluoride was excreted in the urine 15 minutes and 9 hours respectively, after injection (Wallace-Durbin, 1954). Nine hours after the injection $85-878$ of the dose was accounted for in the urine and skeleton. In the present investigations the fraction of the administered dose excreted in the urine was unaffected by route of administration (i.p. vs. i.t.) or the fluoride dietary status (normal F vs. fluoride depleted rats). Bell, et al. (1961) found similar urinary excretion patterns after acute dosing with $\mathrm{Na}^{18} \mathrm{~F}$ in cattle fed diets containing 7,47 , or $57 \mathrm{ppm}$ fluoride for 8 years prior to injection. These results are in good agreement with those of Ericsson (1966) in which the fluoride content of the diet was found to have no effect on the deposition of fluoride in bone after a single injection of NaF. Wallace-Durbin (1954) found a similar percentage of a $0.15 \mu \mathrm{g}$ or $1.85 \mathrm{mg}$ dose of fluoride to be deposited in the skeleton and excreted in the urine in rats by 9 hours af ter injection.

The consistency of the urinary fluoride excretion, and the independence on dose, previous dietary fluoride exposure or route of administration suggest monitoring of urinary fluoride excretion may provide a good way of estimating the dose of fluoride. In fact, N.I.O.S.H. recommends measurement of urinary fluoride levels in people occupationally exposed to airborne fluorides as a biologic measure of fluoride exposure (NISOH, 1976). In all the studies discussed previously non-nephrotoxic levels of fluoride were used to investigate the distribution and excretion of fluoride. It appears, however, that a certain degree of renal 
injury can occur without impairing fluoride excretion by this organ. Administration of $0.3 \mathrm{mg} / \mathrm{kg}$ uranium (as uranyl nitrate), a dose which resulted in marked renal toxicity as measured by proteinuria and renal histology, was without affect on the fluoride balance in rabbits maintained on $15 \mathrm{ppm} F$ in their drinking water (Smith, et al., 1955). The present investigations also provide some indirect information on this subject. In the NaF retention experiment rats continued to excrete fluoride at a time when marked nephrotoxicity as measured by diuresis had occurred. In that experiment 398 of the estimated fluoride dose was excreted in the urine. This percentage is similar to that reported after administration of non-toxic fluoride doses. These results must be interpreted carefully, however, because the actual urinary fluoride excretion and skeletal fluoride deposition in these rats was used to estimate the absorbed fluoride dose. Certainly animals with severe renal insufficiency characterized by anuria would not be capable of excreting fluoride by this route.

After a marked reduction in dietary fluoride content urinary fluoride slowly decreases. Long periods of time are required before positive fluoride balance is achieved. Presumably the increased fluoride excretion during this period is due to mobilization of skeletal fluoride. In the present study rats consumed approximately $550 \mu \mathrm{g} /$ day when maintained on the normal fluoride regimen and approximately $13 \mu \mathrm{g} F /$ day when on the low fluoride dietary regimen. Urinary fluoride excretion decreased

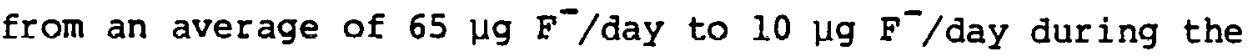


15 day period on the low fluoride dietary regimen. The rats were still in negative fluoride balance, i.e. more fluoride was excreted than consumed, as late as 12 days after initiaton of this low fluoride dietary regimen. If urinary excretion was the only route of removal of fluoride in these rats, then from 2 through 15 days after the marked reduction in dietary fluoride intake, fluoride clearance from the body of these rats could be described by a single exponential decay with a half-time of 8.3 days. The excess fluoride excretion during this period is presumably derived from skeletal deposits. During the 15 day period approximately $0.1 \mathrm{mg}$ more fluoride was excreted in the urine of these rats than was consumed. This is only a small fraction of the $2.6 \mathrm{mg}$ fluoride estimated to have been deposited in the skeleton on the basis of the femoral fluoride content. Plasma fluoride concentrations were. not decreased 6 days after the marked reduction in dietary fluoride intake. Ophaug and Singer (1977) have reported a similar phenomena. In their rat studies plasma ionic fluoride concentrations were significantly elevated over pre-exposure levels as late as 28 days after cessation of a 28 day dietary exposure to $25 \mu \mathrm{g} \mathrm{F} / \mathrm{ml}$ in the drinking water. These authors suggest that the elevated fluoride concentrations are due to mobilization of skeletal fluoride as skeletal fluoride decreased during this time. Ericsson (1975) has reported elevated plasma fluoride levels in a patient many weeks after cessation of sodium fluoride therapy.

All HF exposure regimens used in this study resulted in significant elevations in lung, plasma and kidney fluoride 
concentrations. Because of the large amounts of fluoride present in the skeletons of these rats it is possible that the increased soft tissue fluoride concentrations after HF exposure are due to increased mobilization of skeletal fluoride rather than absorption of inhaled HF. That this is not occurring is shown by the fact that skeletal fluoride content (as estimated from femoral fluoride content) was significantly increased over control levels by HF exposure in the whole body HF retention experiment and the $75 \mathrm{mg}$ $\mathrm{F} / \mathrm{m}^{3}$ nose-only exposure. Skeletal fluoride content was also significantly increased by NaF dust exposure. This possibility cannot be totally eliminated in experiments in which increased femoral fluoride was not demonstrated, but it seems extremely unlikely.

As discussed previously, measurement of urinary fluoride excretion and/or skeletal fluoride deposition in rats exposed to $\mathrm{HF}$ should provide a reasonable estimate of the absorbed fluoride dose due to exposure. After whole body exposure to $10.2 \mathrm{mg} \mathrm{F} / \mathrm{m}^{3} \mathrm{HF}$ for 6 hours these estimates gave a value of $4500 \mu \mathrm{g} F$ as the absorbed dose. At a pulmonary ventilation rate of $0.150 \mathrm{l} / \mathrm{min}$ (Guyton, 1947) these 300 gram rats would have inhaled approximately 500 ug fluoride during exposure. The large difference between these estimates strongly suggests that whole body HF exposed rats absorb fluoride from a source other than inhalation. In fact these rats may have absorbed 9 times more fluoride from this unknown source than they inhaled. A similar problem occurred after nose-only exposure but its magnitude was much smaller (765 $\mu \mathrm{g} \mathrm{F}$ 
estimated absorbed vs. $378 \mu g$ estimated inhaled). The results of this study provide a great deal of evidence that indicates this additional source of fluoride is due to deposition of airborne $\mathrm{HF}$ on fur and subsequent ingestion of that fluoride as a result of preening activity.

The elevated fecal fluoride concentrations in airborne $\mathrm{HF}$ and Naf exposed rats suggests that considerable amounts of fluoride are being ingested. Intravenous injection of fluoride has been shown to result in elevated fecal fluoride concentrations, but less than 58 of the administered dose was sequestered in this site (Wallace-Durbin, 1954). Less than 28 of the intraperitoneally injected fluoride was found in the feces in the present studies. Shortly after whole body exposure to HF or NaF dust fecal fluoride excretion exceeded that in the urine. Thus, the large amounts of fluoride in the feces after whole body exposure are much larger than can be explained by fecal sequestration of absorbed fluoride. The chamber operating characteristics during the dose-response experiment were consistent with the hypothesis that considerable amounts of airborne HF deposited on the fur. Rats removed much more HF from the air, as estimated by the chamber operating characteristics, than could be explained on the basis of inhalation. The smaller magnitude of the unknown fluoride source in nose-only exposed rats compared to rats whose entire bodies were exposed to HF is also consistent with the hypothesis that the unknown fluoride source is due to $\mathrm{HF}$ deposited on the fur. Large amounts of fluoride were present on the fur in direct contact with 
HF atmospheres after nose-only exposure. In fact the sum of the amount of fluoride present on this fur covering the nose and the estimated amount of fluoride inhaled during nose-only exposure agree well with the estimation of the amount of absorbed fluoride. In nose-only exposed rats the amount of fluoride on the fur covering the nose decreased during the post-exposure period. Several processes may be involved in the removal of HF from the fur. Among these are preening, volatilization and absorption through the skin. The relative magnitude of these processes is unknown. Rats undertook a considerable amount of preening of the nose during the post-exposure period. In fact this behavior was evident before the rat entirely recovered fran the anaesthetic. Wiping of the fur around the nose with a wet gauze, a process which may mimic preening, removed a considerable amount of fluoride, suggesting that the fluoride on the fur is "preenable." As has been previously discussed ingested fluoride is readily and efficiently absorbed. The $7 \mathrm{~cm}^{2}$ area of nose fur analyzed contained approximately $300 \mu g$ fluoride. If the deposition of HF on fur covering other areas of the body are similar, then enormous amounts of fluoride must have been present on the fur after whole body exposure, certainly enough fluoride to account for the excess of $4000 \mathrm{\mu g}$ fluoride estimated to be absorbed by these rats.

It is possible to speculate a mechanism for the high desposition of HF on fur. In addition to being a small molecule, HF has a high dipole moment and thus forms strong hydrogen bonds (Masterton and Slowinski, 1969). Thus, airborne HF may diffuse 
into the protein structure of hair and be held there by hydrogen bonding. Preening activity may provide enough water that $B F$ dissolves forming $\mathrm{H}^{+}$and $\mathrm{F}^{-}$which can then be easily removed.

It is unclear how much of an effect the additional source of fluoride has on the systemic fluoride burden of rats sacrificed shortly after exposure. The urinary fluoride excretion of rats during the first 18 hours after whole body exposure to $10.2 \mu \mathrm{g}$ $\mathrm{F} / \mathrm{m}^{3}$ HF for 6 hours accounted for more fluoride than was estimated to be inhaled, suggesting that considerable amounts of preening had taken place by this time. It certainly cannot be assumed that the speculated preening problem had no effect on the systemic fluoride burden of rats sacrificed 6 hours after a 6-hour whole body exposure. All rats used in the dose response experiment were sacrificed at this time, indicating that the fluoride concentrations in soft tissues of these rats must be interpreted very carefully.

In certain experiments, because rats were anaesthetized throughout the entire experimental period, the possibility of preening was totally eliminated. These include the rats sacrificed immediately after nose-only or upper respiratory tract exposure. In each of these experimental animals soft tissue fluoride concentrations were elevated over control levels suggesting that inhaled HF was absorbed. The possibility of increased skeletal fluoride mobilization cannot be eliminated in these animals. That significant absorption of HF through the skin did not occur during upper respiratory tract exposure was shown by the control group 
whose heads were exposed to $\mathrm{HF}$ atmospheres but had no air drawn through their upper respiratory tract. Plasma fluoride concentrations in these rats were not elevated over control levels. The dose-dependent increase of plasma fluoride concentration with increasing airborne HF concentration indicates a cause and effect relationship and strongly suggests that inhaled HF is in fact absorbed systemically. If the possibility of increased skeletal fluoride mobilization is discounted, then from the results of these experiments information on the site of absorption, the rate of absorption and the efficiency of absorption can be inferred. Under the conditions of the upper respiratory tract exposure the removal of HF from the airstream was nearly complete $(<99.98)$. This removal of airborne HF is, presumably, due to deposition of HF within this anatomical site. In this thesis the term "upper respiratory tract" is used to describe all portions of the respiratory tract cephalad to the larynx, and to the extent that air passes through the oral cavity this anatomical site is included as well. However, as discussed previously, it seems unlikely that under the experimental conditions used air actually flows through the oral cavity. The results of these exposures are consistent with this hypothesis. Patten, et al. (1978) have shown that fluoride absorption through the oral cavity is very slow, only 78 of the fluoride applied in this site being absorbed in 2.5 hours. If significant amounts of the HF were being drawn through the oral cavity and depositing there during upper respiratory tract exposure, then the elevated plasma fluoride concentrations observed 
could not have occurred. That HF actually deposited in the upper respiratory tract is indicated by the large amount of this ion that could be removed from this site by rinsing after exposure. Similar amounts of fluoride were removed fram the upper respiratory tract of intact nose-only exposed rats suggesting that the deposition of airborne HF in this site was similar under both sets of experimental conditions.

The deposition of several other gases in the upper respiratory tract using techniques similar to the one described here has been reported. Perhaps the most widely studied compound in this respect is $\mathrm{SO}_{2}$. At physiologic flow rates deposition efficiencies as high as 99.998 for $\mathrm{SO}_{2}$ in the nasal cavity of the dog havebeen reported (Frank, et al., 1969). The fraction of $\mathrm{SO}_{2}$ which penetrates the upper respiratory tract appears to depend on the initial airborne concentration; the fractional penetration decreases with increasing airborne concentration (Strandberg, 1964). Deposition efficiencies of 958 for ammonia have been reported (Dalhamn and Sjoholm, 1963). Formaldehyde is nearly completely removed from the air by passage through the upper respiratory tract of the dog (Egle, 1972), whereas only $80 \%$ of proprionaldehyde and $60 \%$ of acrolein drawn through this site were removed. In general the deposition efficiency correlates with water solubility, the more soluble compounds being removed with greater efficiency. At low concentrations (less than $2 \mathrm{mg} / \mathrm{m}^{3}$ ) it has been reported that 908 of inspired $\mathrm{NO}_{2}$ is removed from the alrstrean by passage through the upper respiratory tract of the dog 
(Vaughan, et al., 1969). At high concentrations $\left(50-760 \mathrm{mg} / \mathrm{m}^{3}\right.$ ) only 508 of the $\mathrm{NO}_{2}$ drawn through this site was removed from the air by the rabbit (Dalhamn and Sjoholm, 1963). The penetration of ozone through the upper respiratory tract has also been shown to be concentration dependent. At physiologic flow rates 288 of the ozone at an initial airborne concentration of $0.3 \mathrm{ppm}$ penetrated through the nasal passages of the dog, at $0.8 \mathrm{ppm}$ the fractional penetration was 418 (Yokohama and Frank, 1972). Vaughan, et al. (1969) also reported a similar relationship with ozone concentrations in the 1-12 ppm range. No effect of the initial airborne concentration on the fractional penetration of HF through the upper respiratory tract $\infty u l d$ be discerned in this experiment because detectable amounts of $\mathrm{HF}$ never penetrated through the site at the airborne concentrations used here.

of the wide $r$ ange of gases studied $\mathrm{HF}$ appears to $r$ ank among those most efficiently collected in the upper respiratory tract. Presumably gas molecules drawn through the upper respiratory tract diffuse to the mucosal surface and dissolve if sufficiently soluble. In his discussion on the deposition of gases in the nasal cavity Davies (1946) points out the importance of high solubility. If the mucosal surface were to become saturated with gas then net deposition would stop. The deposition of gases with low solubility may be governed by the rate at which molecules are removed from the mucosal surface. If such a process were to occur the penetration through the upper respiratory tract might be expected to be time dependent. At the start of exposure small 
amounts of gas would penetrate because little or no gas is dissolved in the mucosal surface. However, as the mucosal surface became saturated more and more gas would penetrate through the upper respiratory tract because less and less is becoming dissolved. The penetration of ozone through the upper respiratory tract has been shown to decrease with increasing length of exposure (Yokohama and Frank, 197.2). In light of its low molecular weight (HF does not polymerize at the partial pressures and temperatures encountered in this work, Leech, 1956), and its high water solubility, the high collection efficiency of HF by the upper respiratory tract is, perhaps, not unexpected.

The deposition of HF in the upper respiratory tract of rats was investigated at one flow rate $-0.141 / \mathrm{min}$. It would be interesting to study this process at a higher flow rate, especially since maximal flow rates in the rat may reach $0.301 / \mathrm{min}$ (Palecek, 1969) during respiration. Increased flow rates, by decreasing the residence time in the upper respiratory tract, would be expected to result in decreased diffusional deposition. However, increased flow rates will increase turbulence which may lead to increased mixing and perhaps increased penetration of air into the nasal turbinates. Since these processes might be expected to enhance diffusional deposition on the mucosal surface it is not possible to predict accurately the effects of increased flow on nasal penetration of gases. A few investigators have studied nasal penetration at two flow rates. The penetration of $0.3 \mathrm{ppm}$ ozone through the upper respiratory tract of the dog was increased from 
288 to 638 by a ten fold increase in flow (Yokoyama and Frank, 1972). A 10-fold increase in flow rate resulted in a 32-fold increase in the penetration of $\mathrm{SO}_{2}$ through the upper respiratory tract of the same species (Frank, et al., 1969). At similar initial concentrations a 10-fold increase in flow resulted in a 160-fold increase in the penetration of $\mathrm{SO}_{2}$ through the mouth of the dog. These results show that increased penetration through the upper respiratory tract occurs as a result of increased flow rates; however, comparison of the results in the nose and the mouth suggests that the magnitude of the increased penetration through the upper respiratory tract due to increased flow rates may be moderated by increased turbulence or increased flow into the nasal tur binates.

In their study on the absorption of war gases in the nose of the rabbit, Cameron, et al. (1946) found a good correlation between nasal deposition and nasal injury. These authors reported 80-90\% deposition of mustard and nitrogen-mustard gas in the nasal cavity. After exposure to these gases marked inflammation and hemorrhage of the nasal epithelium was found. Only $25 \%$ of the phosgene drawn through the nasal cavity deposited in that site and little pathologic alteration was noted. The authors noted that the concentrations of phosgene used invariably result in the formation of pulmonary edema, while pulmonary edema was not a common finding after exposure to the mustard gases. The tracheal sampling tube became plugged with mucous from rabbits exposed to high concentrations of the mustard gases. A similar effect was noted in 
rats exposed to high concentrations of HF. The injury caused to the upper respiratory tract of rats exposed to $\mathrm{HF}$ is similar to that reported for the mustard gases. Rosenholtz, et al. (1963) reported extensive mucosal and submucosal necrosis and accompanying acute inflammation to be present in the nasal cavities of rats exposed to near lethal concentrations of HF. The nasal cavities of rats exposed to $\mathrm{HF}$ in the present investigations were not examined histologically. This type of pathologic change might be expected to alter the collection efficiency of the upper respiratory tract. The collection efficiency of the upper respiratory tract has been reported to increase with increasing initial $\mathrm{SO}_{2}$ concentrations (Strandberg, 1964). This author suggested that $\mathrm{SO}_{2}$ induces a dose-independent increase in mucous secretion, and the increased mucous layer in the nasal cavities of rabbits exposed to higher $\mathrm{SO}_{2}$ concentrations, being capable of dissolving more $\mathrm{SO}_{2}$, results in an increased collection efficiency of this gas. In the present studies, since detectable amounts of fluoride did not penetrate through the upper respiratory tract, it was not possible to determine if such a process was occurring during HF exposure. Under the artificial conditions of the upper respiratory tract exposure, virtually no HF penetrated to the trachea. The results of HF exposures in intact rats are consistent with this finding, indicating that the conditions of the upper respiratory tract exposure are similar enough to the true in vivo conditions that the technique is an adequate model system to use for investigations of nasal deposition of inhaled gases. 
In both intact nose-only exposed rats and upper respiratory tract exposed rats large amounts of fluoride could be rinsed fram the upper respiratory tract after exposure, indicating that large amounts of $\mathrm{HF}$ deposit in this region under both sets of conditions. The ionic fluoride concentration in lungs of rats sacrificed immediately after nose-only exposure to $63 \mathrm{mg} \mathrm{F} / \mathrm{m}^{3} \mathrm{HF}$ for I hour was less than the ionic plasma fluoride concentration. Thus there is no evidence that fluoride reached the lungs by any other route than transport through the plasma. Tracheal fluoride concentrations in rats sacrificed immediately after HF exposure were not elevated over control levels again, suggesting that little HF penetrated through the upper respiratory tract of these rats during exposure. The ionic fluoride concentrations" in lungs of rats after whole body exposure to HF for 6 hours were slightly higher than plasma ionic fluoride concentrations suggesting that under these experimental conditions some HF reached the lungs by a route other than plasma transport. However, as discussed below the lung may contain binding sites for the fluoride ion. Thus it is possible that the entire pulmonary fluoride burden in whole body HF exposed rats may be due to plasma transport of fluoride that was absorbed at another site. Even if no binding were to occur the penetration of only a small fraction of the inhaled HF would account for the pulmonary fluoride burdens in these whole body exposed rats. Estimation of the expected pulmonary fluoride burden in the whole body exposed rats using the pulmonary retention kinetics found after whole body exposure, ignoring the long term retention 
component which may be due to preening, assuming a pulmonary ventilation rate of $0.15 \mathrm{l} / \mathrm{min}$ for a $300 \mathrm{gram} r a t$ (Guyton, 1947) and assuming continuous inspiration at that rate, reveals that the pulmonary fluoride burdens in rats exposed to all concentrations used in the dose response experiment could be explained on the basis of 18 penetration of HF through the upper respiratory tract. Thus under all experimental conditions used, whole body exposure for 6 hours, 1 hour nose only exposure or intermittent 5 minute upper respiratory tract exposure, little HF penetrates through the upper respiratory tract to the lower airways. Addition of water vapor to chamber HF atmospheres may have altered the regional deposition of inhaled HF. The pulmonary fluoride burden in rats exposed to $111 \mathrm{mg} \mathrm{F} / \mathrm{m}^{3} \mathrm{HF}$ plus water vapor was significantly less than in rats exposed to $116 \mathrm{mg} \mathrm{F} / \mathrm{m}^{3}$ suggesting that water vapor increased the nasal deposition of inhaled HF. However, the rats exposed to HF plus water vapor were considerably older than those exposed to HF alone so the differing pulmonary fluoride burdens may be due to age dependent alterations in the binding of fluoride in pulmonary tissue. Similarly the differences of the pulmonary fluoride burdens in Blue Spruce or Charles River rats after exposure to similar airborne $\mathrm{HF}$ concentrations may be due to differences in the binding of fluoride in the lung or to differences in regional deposition of inhaled HF. The high collection efficiency of the upper respiratory tract for HF suggests that binding or some other unknown phenomenon may be the more important factor determining lung fluoride concentrations in these rats. 
In light of its high collection efficiency, the upper respiratory tract appears to protect the lower airways from the effects of HF. The absence of pulmonary edema in HF exposed rats suggests such protection is occurring. It would be extremely interesting to expose rats to HF through an endotracheal tube leading directly to the lung, thus eliminating the protection of the upper respiratory tract. It would be expected that not only would high lung fluoride concentrations occur, but that pulmonary edema might ensue. As early as 1913 it was noted that the tracheotomized dog was more susceptible to ozone as measured by pulmonary edema, than the intact dog (Jordan and Carlson, 1913) . From their results these authors speculated that as much as 758 of inhaled ozone may be removed by the upper respiratory tract, a prediction remarkably similar to the collection efficiencies of 50-75\% measured in the dog over 50 years later (Vaughan, et al., 1969). Using increased pulmonary flow resistance as the response to $\mathrm{SO}_{2}$ Amdur (1966) has reported that the tracheotomized guinea pig is more sensitive to this pollutant than the intact guinea pig. A large fraction of inhaled $\mathrm{SO}_{2}$ is deposited in the upper respiratory tract (Strandberg, 1964).

The rich vasculature of the nasal cavity suggests that once deposited, compounds may be rapidly absorbed from this site. Certainly cocaine can be absorbed through the nasal epithelium. In few of these studies in which the nasal deposition of inhaled gases were investigated was there any attempt to determine if the gases were absorbed systemically. Yokoyama, et al. (1971) did show 
increased ${ }^{35} \mathrm{~S}$ activity in the blood of dogs exposed to ${ }^{35} \mathrm{SO}_{2}$ via the upper respiratory tract. Recently Dahl, et al. (1979) have shown increased blood ${ }^{35} \mathrm{~S}$ levels after instillation of $\mathrm{H}_{2}^{35} \mathrm{SO}_{4}$ in the nasal cavity of the dog. Dahl, et al. (1979) also instilled $\mathrm{H}_{2}{ }^{35} \mathrm{SO}_{4}$ in the lung of the dog and concluded that the absorption into blood from this site, based on the rate of increase of ${ }^{35} \mathrm{~S}$ activity in the blood, was much faster than absorption through the nasal epithelium. From the plasma ionic fluoride concentrations after upper respiratory tract exposure it was estimated that at least $20 \%$ of the HF drawn into the upper respiratory tract. of the rats was absorbed systemically during the 36 minute experiment. Thus absorption of $\mathrm{HF}$ through the nasal cavity appears to be fairly rapid. Complete absorption of $\mathrm{HF}$ through the nasal epithelium may not be rapid. Significantly more fluoride could be removed from the upper respiratory tract of the rat 7,12 and 24 hours after the start of the 1 hour nose-only exposure than could be rinsed from controls. It should be stated that the rinsing procedure did not appear to quantitatively remove fluoride from this site. However, the removal of more fluoride from this site in exposed rats than from controls suggests that more fluoride was actually present. The amounts of fluoride which were rinsed out of the respiratory tract at this times were small, in general, less than $1 \mu g$, compared to the $35-45 \mu \mathrm{g}$ fluoride removed immediately af ter exposure, but they provide evidence that a small fraction of the fluoride in the upper respiratory tract after $\mathrm{HF}$ exposure is retained for several hours. 
In rats exposed to $36 \mathrm{mg} \mathrm{F} / \mathrm{m}^{3} \mathrm{HF}$ in the upper respiratory tract experiment the plasma ionic fluoride averaged $0.31 \mu \mathrm{g} / \mathrm{ml}$ compared to a control value of $0.11 \mu \mathrm{g} / \mathrm{ml}$. Immediately after nose-only exposure to $63 \mathrm{mg} \mathrm{F} / \mathrm{m}^{3}$ for 1 hour the plasma ionic fluoride concentration in intact rats averaged $0.26 \mu \mathrm{g} / \mathrm{ml}$ (control $0.04 \mu \mathrm{g} / \mathrm{ml})$. While direct comparison of these plasma fluoride concentrations in rats exposed to $\mathrm{HF}$ via these two regimens cannot be made because of the different time course in each experiment, the results do suggest that deposition and absorption of $\mathrm{HF}$ in the nasal cavity is of sufficient magnitude to account for the fluoride concentrations present in tissues of intact rats after nose-only exposure.

It can be assumed a priori that absorption of fluoride into the blood stream through the nasal epithelium during exposure to HF is not instantaneous. The large amounts of fluoride which can be rinsed from the upper respiratory tract immediately after exposure indicate a time lag between deposition and absorption. Absorption of fluoride into the blood stream during intravenous fluoride ion infusion is immediate. Approximately 68 of the infused dose of fluoride was present in the urine immediately after the 1 hour infusion. If a pulmonary ventilation rate of $0.101 / \mathrm{min}$ for the anaesthetized rat is assumed, approximately 28 of the inhaled dose of fluoride was present in the urine at the end of the 1 hour period nose-only exposure, again suggesting that absorption of inhaled HF is fairly rapid. In the model of fluoride metabolism in the rabbit by Hall, et al. (1977), the fractional transfer rate of the 
fluoride ion from intracellular to extracellular fluid was estimated to be $0.0911 \mathrm{~min}^{-1}$. This corresponds to a half-time of 7. 6 minutes. Absorption of $\mathrm{HF}$ through the nasal epithelium would not be expected to be faster than this.

It was hoped to use the urinary fluoride excretion in rats after HF exposure to estimate the inhaled dose of fluoride, but as discussed this was not possible due to the problem speculated to be a result of preening. Other experiments however, suggest that nearly 1008 of inhaled HF is absorbed. Deposition of HF drawn through the upper respiratory tract was greater than 99.98 . Complete deposition of inhaled gases is not unheard of. Inhaled $\mathrm{SO}_{2}$ is nearly completely removed from the air by the upper ai rways of the human subject (Speizer and Frank, 1966). Comparison of inspired and expired air concentrations of formaldehyde indicated that the dog completely removes this solvent from the air during respiration. However, complete removal of substances from the air does not indicate that complete systemic absorption occurs. In HF exposed rats the slow return of the fluoride content in nasal washes to control levels suggests that removal of deposited HF from the upper respiratory tract is complete. The increased plasma fluoride concentrations in nose-only $\mathrm{HF}$ exposed and especially upper respiratory tract $\mathrm{HF}$ exposed $r$ ats suggested that a significant fraction of the deposited $\mathrm{HF}$ is removed from the upper respiratory tract by absorption into the blood stream. 
Absorption of inhaled $\mathrm{HF}$ has been shown to occur in the human by elevations in urinary fluoride excretion after exposure (Largent, 1961). Both whole-body and nose-only HF exposure resulted in a prompt increase in urinary fluoride excretion in the rat. In rats exposed to HF via either exposure regimen maximal daily urinary fluoride excretion occurred on the day of exposure. The excess ur inary fluoride excretion resulting from nose-only HF exposure was not complete within 24 hours after the start of exposure. Approximately 108 of the total amount of excess fluoride excreted by the nose-only exposed rats was excreted during the 24-48 hour period. This delayed excretion may be due to preening. However, a similar phenomenon has been reported in man. The urinary fluoride excretion was elevated over baseline levels in two subjects 24-48 hours after the start of an 8 hour exposure to gaseous fluoride at an airborne concentration of approximately $3 \mathrm{mg} \mathrm{F} / \mathrm{m}^{3}$ (Collings, et al., 1951). The exact nature of the gaseous fluoride compounds was not specified, however the author stated that the gaseous fluorides were principally $\mathrm{HF}$ and $\mathrm{SiF}_{4}$. The excess fluoride excretion during this $24-48$ hour period averaged 108 of the total excess fluoride excretion in these individuals. Rye (1961) reported elevated urinary fluoride excretion in subjects during the 24-48 and 48-72 hour periods after the start of an 8 hour exposure to approximately $2.0 \mathrm{mg} \mathrm{F} / \mathrm{m}^{3}$ gaseous fluoride. The nature of the gaseous fluoride compounds was not determined. Largent (1961) measured urinary fluoride excretion in humans after exposure to various low HF airborne concentrations for 6 hours per 
day, 5 days per week for several weeks. In his figure showing the urinary fluoride excretion of one individual it appears that the fluoride excretion may have been elevated during days on which no exposure occurred, but Largent makes no mention of it. The results of human exposures may indicate that excess urinary fluoride excretion during the $24-48$ hour period in the rats might be due to inhaled HF rather than preened fluoride. The excess fluoride excretion during this time priod would be expected to be due to delayed absorption of fluoride as excess fluoride excretion was not evident 24-48 hours after fluoride injection. Excess fluoride was rinsed from the upper respiratory tract of rats at 7,12 and 24 hours, so this may be the site of delayed absorption. However, at 12 hours only $1 \mathrm{\mu g}$ fluoride was rinsed from this site and approximately $55 \mathrm{\mu g}$ fluoride would be necessary to account for the $12 \mu \mathrm{g}$ of excess fluoride excretion during the 24-48 hour pertod $(55 \mu \mathrm{g} \times 228=12 \mu g)$. From the $4 \mu \mathrm{g}$ fluoride wiped off the fur at 12 hours it was estimated that $30 \mu \mathrm{g}$ fluoride was present on the fur at this time. Thus, it seems that the fur is the more Iikely source of delayed absorption rather than the upper respiratory tract. It is unfortunate that the animal models used are not capable of determining if excess fluoride excretion occurs many hours after HF exposure. Fluoride would accumulate in soft tissues of workers exposed to HF in the workplace if excretion were not complete during their off hours. Accumulation of this ion in any tissue would increase the chances of toxicity. 
Soft tissue fluoride concentrations were elevated by every HF exposure regimen used. As late as 21 days after whole body HF exposure ionic fluoride concentrations in lung, plasma and kidney were significantly higher than control levels. However, as discussed this long term retention was probably due to preening activity. Long term retention of fluoride in soft tissues was not detected after nose-only exposure where preening would be minimal. The fluoride ion is thought to distribute throughout the soft tissues of the body by diffusion (Smith, 1966). Thus fluoride concentrations in soft tissues would not be expected to be higher than in plasma. After whole-body exposure fluoride ion concentrations in both soft tissues analyzed, lung and kidney, exceed that in plasma. Fluoride is excreted in the urine; high kidney fluoride concentrations may be due to entrapped urine in that organ. The fluoride ion is not volatile and, thus, would not be expected to be excreted through the lung. Lung fluoride concentrations in excess of that in plasma in rats sacrificed immediately after $\mathrm{HF}$ exposure could be due to inhaled $\mathrm{HF}$ reaching the lung via the airways, but shortly after exposure lung fluoride ion concentrations would be expected to decrease to the level in the plasma by diffusion of the ion down a concentration gradient. Lung fluorlde ion concentrations were determined on lung homogenates. In this process the pulmonary tissue is diluted with 5 to 6 parts water and mixed 1:1 with TISAB. If lung ionic fluoride were in equilibrium with a loosely bound fluoride species then this homogenlzation procedure might be expected to cause dissociation of 
this species, furnishing additional ionic fluoride. Thus, the fluoride measured as ionic in nature by this procedure may not exist as a free ion solution in the tissue in vivo. As late as 21 days after whole body HF exposure or 8 days after NaF dust exposure the measured ionic fluoride concentration in the lung significantly exceeded that in plasma indicating that some binding or active transport of fluoride ion in pulmonary tissue is occurring. These experiments cannot distinguish between these possibilities.

Knaus, et al. (1976) reported that ${ }^{18} \mathrm{~F}$ concentrations in the lungs of rats after 3 hours continuous intravenous infusion of 0.9 to $6.0 \mathrm{mg} \mathrm{F} / \mathrm{kg}-\mathrm{hr}$ as $\mathrm{Na}^{18} \mathrm{~F}$ exceeded plasma concentrations by 3 fold. In addition 1 ung ${ }^{18} \mathrm{~F}$ levels decreased more slowly than plasma ${ }^{18} \mathrm{~F}$ after termination of the infusion. This experiment of Knaus, et al. led to the performance of the intravenous fluoride infusion experiment described in this thesis. After a 1 hour infusion both total and ionic lung fluoride concentrations were elevated, but not to levels higher than present in plasma. Perhaps longer infusion periods are necessary before fluoride accumulates in the lungs. Bell, et al. (1961) measured the fluoride concentration in tissues of cattle maintained for 8 years on diets containing fluoride concentrations of 7,47 or $57 \mu \mathrm{g} / \mathrm{g}$. In these animals lung Ruvicle cuncentrations exceeded blood fluoride concentration by approximately 7-fold. Bell, et al. also measured ${ }^{18} \mathrm{~F}$ concentrations in several tissues of these cattle 4 hours after intravenous injection of $\mathrm{Na}^{18} \mathrm{~F}$. The ${ }^{18} \mathrm{~F}$ content in blood; tissues and urine after injection was unaffected by 
previous ditary intake. The ${ }^{18} \mathrm{~F}$ concentration in only two soft tissues exceeded that in blood. These tissues were the lung and the kidney. As mentioned, kidney fluoride concentration in excess of that in plasma is not unexpected since the urine is the major route of excretion of fluoride. Lung ${ }^{18} \mathrm{~F}$ concentration in these cattle averaged 4.3 times that in blood. Fluoride does not distribute equally between red blood clls and plasma. Two investigations (Carlson, et al., 1960a; Wallace-Durbin, 1954) have shown the fluoride concentration in red blood cells at equilibrium to average approximately one-half of that in plasma. Thus, at a hemocrit of $50 \%$ plasma fluoride concentration will equal 1338 of the whole blood fluoride concentration. Bell measured this ratio in these cattle and found it to be similar. The higher fluoride concentration in plasma than in whole blood, therefore, does not account for the high fluoride concentrations in the lung. Bell, et al. (1961) also reported that the ${ }^{18} \mathrm{~F}$ concentration in nasal mucous of cattle injected with $\mathrm{Na}^{18} \mathrm{~F}$ was quite high. This suggests an interesting possibility. Perhaps the high fluoride concentrations in lungs of rats after HF inhalation are due to accumulation of fluoride in mucous. Such speculation can explain several of the results of this study. Tracheal fluoride concentrations were quite high compared to plasma and were quite variable. Wallace (1953) reported high tracheal ${ }^{18_{F}}$ concentrations in the rat after intravenous $\mathrm{Na}^{18} \mathrm{~F}$ injection and suggested binding of fluoride to sites of ectopic calcification as a caluse of this effect. F'luoride ion has been shown to accumulate 
at sites of ectopic calcification in the placenta (Ericsson and Ullberg, 1958). If sites of ectopic calcification were present in the trachea and major airways of the lung the increased lung and tracheal fluoride concentrations could be explained. However, such a process does not explain the dynamic nature of tracheal fluoride concentration. The tracheal fluoride concentration was significantly less than control values immediately after nose-only HF exposure, but returned to and surpassed control levels during the postexposure period. If the major fraction of the fluoride measured in the trachea was actually present in the mucous layer then an inhibition of mucous secretion in the lung and/or transport up to the tracheobronchial tree could explain these results. A high affinity of fluoride for mucous might also help to explain the apparent retention of fluoride in the upper respiratory tract after nose-only exposure.

Nasal mucous in the human has been shown to contain $\mathrm{Ca}^{++}$, $\mathrm{PO}_{4} \equiv$ and albumin (Lorin, et al., 1972). The efficiency of the calcium phosphate adsorption technique (Venkateswarlu, et al.. 1971) points out the high affinity of the fluoride ion for calcium phosphate, however, the calcium and phosphate in mucous probably do not exist as a crystalline salt. Carlson, et al. (1960a) has shown that while neither albumin or $\mathrm{Ca}^{++}$alone effects the ultrafilterability of the fluoride ion, when present together as much as 308 of the fluoride ion becomes ultrafilterable. Such a binding phenomenon might explain a high affinity of fluoride for mucous. The possibility of an active transport system cannot be 
totally eliminated. Olver and Strang (1974) have shown that $\mathrm{Cl}^{-}$, $\mathrm{Br}^{-}$and $\mathrm{I}^{-}$are actively transported across the fetal lamb lung epithelium. In addition Olver, et al. (1975) have reported evidence suggesting that chloride is actively transported across the tracheal epithelium of the dog. Perhaps such transport systems are present in the respiratory tract of the rat and they have an affinity for fluoride as well as the other halogens. However, fluoride does not accumulate in the thyroid (Wallace-Durbin, 1954; Bell, et al., 1961) and the kidney appears able to discriminate between fluoride and chloride (Carlson, et al., 1960b). The preceding discussion is certainly speculative, but it might provide some interesting areas for future research.

No long term retention of fluoride was evident in the lungs of nose-only HF exposed or NaF infused rats. In the case of the nose-only exposed $r$ ats the initial lung fluoride burden was so low that a long term retention of $10 \%$ of the initial burden would go undetected. The initial lung fluoride levels in rats infused with NaF were, however, high enough that a long term retention of fluoride in that organ, if it followed the same kinetics as after whole body exposure, would have been detected. Long term pulmonary retention of fluoride was only evident in whole body exposed rats, rats in which a large unknown source of fluoride speculated to be due to contamination of the fur was detected. Perhaps the long term elevations in plasma fluoride due to preening, lead to even larger increases in lung fluoride due to same undefined binding or active transport process. 
The retention characteristics of fluoride in the rat following exposure to HF generated by the compressed gas system or by the aqueous system were not similar. After exposure to HF generated by the aqueous system soft tissues of rats contained large amounts of fluoride which did not respond to the fluoride ion sensitive electrode. This fluoride component in soft tissues is termed the $\Delta F$ fraction. Its concentration was obtained by subtracting the measured ionic fluoride concentration in each tissue from the measured total concentration.

Taves (1968a) reported that human plasma total fluoride concentration, measured in ashed samples, exceeded the ionic fluoride concentrations determined in unashed samples. He termed the difference "non-exchangeable fluoride" and found that it migrated with albumin when subjected to electrophoresis (Taves, 1968b). In subsequent purification 378 of this fraction was recovered and was found to have an NMR spectra similar to a $C_{6-8}$ perfluoro fatty acid derivative (Guy, et al., 1976). Perfluorofatty acids are used industrially in the treatment of fabrics and leathers. In this same study Guy, et al. measured total and ionic fluoride concentrations in plasma obtained from people living in communities with differing levels of fluoride in the drinking water. No correlation between drinking water fluoride concentration and levels of piasma "organic fluoride" were found, leading the authors to suggest that organic fluorocompounds derived from commercial products were present in human plasma. 
Patterson, et al. (1977) reported that total fluoride concentration in the serum of the sheep, rabbit and $r$ at exceeded ionic fluoride concentration. Ophaug and Singer (1977) reported similar findings. These authors attribute the difference to "bound fluoride". In the present studies total fluoride concentration in plasma, lung and kidney of control rats consistently exceeded ionic fluoride concentration. However, in control rats the levels of total and ionic fluoride were so low compared to the limit of sensitivity of the analytical methods that no true quantitative value for the level of $\Delta F$ could be obtained. In all other studies (Taves, 1968a; Guy, et al.., 1976; Patterson, et al., 1977; Ophaug and Singer, 1977) the concentrations of total and ionic fluoride were also quite low, close to the limits of sensitivity of the analytical methods employed. In every case $\Delta F$, bound fluoride or organic fluoride levels were determined indirectly as the difference between two independent analytical methods. This difference is termed $\Delta \mathrm{F}$ in the present report because the analytical techniques employed provide no direct information on the nature of this fluoride fraction.

Ophaug and Singer (1977) have reported evidence that $\Delta F$ (or in their terminology "bound $F "$ ") is actually derived from ionic fluoride. Unfortunately there are uncertainties about the analytical methods employed by these authors (Venkateswarlu, 1975). These authors maintalned weanling rats on a low fluoride diet and distilled water for 14 days, transferred them to low F diet and drinking water containing $25 \mu \mathrm{g} \mathrm{F} / \mathrm{ml}$ (as $\mathrm{NaF}$ ) for 28 days and 
then returned them to distilled water for another 28 days. Bound fluoride was detected initially; its concentration increased while the rats were maintained on $25 \mu \mathrm{g} / \mathrm{ml}$ drinking water and then decreased to pre-exposure levels when the fluoridated water was removed. The rat may respond to ionic fluoride in a manner unlike the human. It seems unlikely that these rats formed perfluoro fatty acid derivatives from ionic fluoride, however, only $37 \%$ of the organic fluoride found in human plasma was so characterized. Perhaps the remaining $63 \%$ of the "organic fluoride" in human plasma is formed in a manner similar to the process in the rat. In the present studies $\Delta F$ levels did not appear to decrease during fluoride depletion, as might be expected from the results of ophaug and Singer (1977). No quantitative comparison of $\Delta F$ levels in control and fluoride depleted rats could be made because the levels of $\Delta F$ under these conditions were so low.

$\Delta F$ concentrations in soft tissues of rats were increased over control levels by exposure to HF generated by either the aqueous or the compressed gas technique. High concentrations of $\Delta F$ were present after aqueous system generated exposures; low levels, levels within the precision of the analytical methods employed, were detected in soft tissues of rats after compressed gas generated exposures. In Blue Spruce rats exposed to $\mathrm{EF}$ generated by the compressed gas technique in the dose-response experiment a dose-dependent increase in plasma $\Delta F$ concentration with airborne HF exposure concentration occurred, indicating a cause and effect relationship. Increased $\Delta F$ concentrations were 
present in rats sacrificed immediately after nose-only compressed gas technique generated HF exposure, but after no other exposure generated by this technique were $\Delta F$ concentrations elevated over control levels. On the basis of the dose-response curve obtained in the dose-response experiment elevated $\Delta F$ concentrations would not be expected in any of these other exposures. A minimal, if any, increase in plasma $\Delta F$ concentration occurred in rats exposed to $11 \mathrm{mg} \mathrm{F} / \mathrm{m}^{3}$ for 6 hours in the dose-response experiment. If the airborne HF concentration times time $(C \times T)$ is taken as a measure of the dose of $\mathrm{HF}$, in no other experiment was the dose higher than after the $11 \mathrm{mg} \mathrm{F} / \mathrm{m}^{3}$ exposure. For example, the $\mathrm{C} x$ $T$ for the whole body $\mathrm{HF}$ retention experiment was $61.2 \mathrm{mg} \mathrm{F}-\mathrm{hr} / \mathrm{m}^{3}$ compared to $66 \mathrm{mg} \mathrm{F-hr} / \mathrm{m}^{3}$ for the $11 \mathrm{mg} \mathrm{F} / \mathrm{m}^{3}$ dose-response exposure. This value for the nose-only HF retention experiment using fluoride depleted rats was approximately $63 \mathrm{mg} F-\mathrm{hr} / \mathrm{m}^{3}$. In addition it is also expected that the dose after nose-only exposure is much less than after whole body exposure because of the additional source of fluoride speculated to be due to contamination of the fur. Negative $\Delta F$ concentrations were obtained in plasma of NaF dust exposed rats. This anomolous result points out the problems associated with quantifying the concentration of a compound by taking the difference of two independent analytical techniques.

Consistent increases in plasma $\Delta F$ concentration were not detected in Chales River rats exposed to HF generated by the compressed gas technique. Any dose-response relationships in these 
rats may have been masked by random analytical error. $\Delta F$ averages about 158 of the total fluoride concentration in plasma of Blue Spruce or Charles River rats exposed to HF generated by the compressed gas technique and the coefficient of variation of the measurement of $\Delta F$ was estimated to be $12.5 \%$.

Very high concentrations of $\Delta F$ were present in the plasma, Iung and kidney of Blue Spruce and Charles River rats after exposure to $\mathrm{HF}$ generated by the aqueous system. In these rats $\Delta F$ accounted for as much as $80 \%$ of the total fluoride present in each soft tissue. In all three tissues, lung, plasma and kidney $\Delta F$ concentrations increased significantly during the post-exposure period. Because of the high concentrations present in these soft tissues it was possible to partially characterize $\Delta F$. The $\Delta F$ fractions in lung and kidney following aqueous system generated $\mathrm{HF}$ exposure have different chemical properties as evidenced by the effects of acid treatment. In kidney homogenates, treatment with trichloracetic acid resulted in the conversion of 678 of the fluoride in the $\Delta F$ fraction to a form which responds to the fluoride ion sensitive electrode. Such treatment was without detectable effect on the $\Delta F$ fraction in lung homogenates. Potassium hydroxide digestion, a procedure which converts the covalently bound fluoride in monofluoracetate and monofluoroproprionate to the fluoride ion, was without effect on lung $\Delta F$ suggesting that in this tissue $\Delta F$ is not a simple monofluoro aliphatic carbon compound. As discussed previously fluoride ion would bind to sites of ectopic calcification. If such 
sites were present in pulmonary and renal tissue, binding of fluoride would be expected to be strong enough that the bound fluoride would not be detected until after ashing and dissolution in acid. Such a process might be occurring in these tissues, but it would not explain the presence of $\Delta F$ in plasma.

Because $\Delta F$ was only determined as the difference between two independent analytical methods, it was thought to be important to at least once separate $\Delta F$ and ionic fluoride to show that at least two chemically distinct forms of fluoride actually exist in plasma. To this end plasma samples obtained from 5 rats exposed to HF generated by the aqueous system were subjected to the calcium phosphate adsorption technique of Venkateswarlu, et al. (1971). This technique separated fluorides on the basis of adsorbability onto crystalline calcium phosphate. Ionic fluoride has a high affinity for this crystal and can be quantitatively removed from solution by this technique. Non-ionizable fluoride remains in solution. The plasma samples subjected to this technique contained on the average $33 \%$ ionic fluoride and $678 \Delta F$, fluoride which did not respond to the fluoride ion sensitive electrode until after ashing. Treatment of plasma samples with calcium phosphate left behind a solution in which 978 of the fluoride did not respond to the fluoride ion sensitive electrode until after ashing. This solution was essentially pure $\Delta F$ and contained $90 \%$ of the recovered $\Delta F$. The remaining 108 of the recovered $\Delta F$ was present in the calcium phosphate phase and may have been trapped there during the centrifugation procedure. An average of 898 of 
the ionic fluoride originally present was recovered in the calcium phosphate layer. The total fluoride recovered averaged 1078 of the amount determined to be present originally, a value well within the precision of the total fluoride method. Thus, this procedure separated plasma fluoride into two components on the basis of adsorbability onto calcium phosphate, and $\Delta F$ was near quantitatively recovered in the non-ionizable fluoride component. Plasma from rats exposed to HF generated by the aqueous system were also subjected to Sephadex G-25 gel chromatography. This chromatographic procedure separates molecules on the basis of molecular radius, a property which is a function of the molecular weight. According to Determan (1969) molecules with a molecular weight in excess of 5000 daltons are excluded by G-25 gel and thus migrate with the void volume. The total fluoride concentration in each elution sample was low compared to the analytical blank, making quantitative determinations of the total fluoride content of each sample difficult. The fluoride present in the plasma sample subjected to this procedure however, was all recovered in samples eluting after the void volume suggesting the molecular weight of $\Delta F$ is less than 5000 daltons. In fact $84 \%$ of the administer ed $\Delta F$ eluted with the bed volume suggesting a very low molecular weight, perhaps less than 500 daltons (Thomas, 1977). This low molecular weight agrees well with the dialyzable nature of $\Delta F$ in kidney homogenates. Ionic fluoride migrated with the bed volume. Taves (1968b) reported that the "non-exchangeable fluoride" present in human plasma was associated to albumin (molecular weight 65,000 
daltons). The $\Delta F$ in rat plasma or kidney does not appear to have this characteristic. In sumary, in plasma and tissue of rats exposed to HF generated by the aqueous system at least two forms of fluoride are present: one ionic in nature, the other (s) consists of low molecular weight chemically distinct non-ionizable fluor ine containing component(s) which do not respond to the fluoride ion sensitive electrode unless ashed. It is not known whether the $\Delta F$ fraction in control rat tissues or in tissues of rats exposed to HF generated by the compressed gas technique have similar properties. The source of the $\Delta F$ fraction is unclear. Since $\Delta F$ was determined indirectly the possibility that its detection is due to analytical error or artifact must be considered. This does not appear to be the case. Standard fluoride analytical methods (Venkateswarlu, 1977) were used for all determinations. Fluoride was quantitatively recovered in the calcium phosphate adsorption and gel chromatographic procedures. In the adsorption technique each plasma was separated into two samples, the sum of the measured total or ionic fluoride content in each sample equalled within analytical error the amount originally determined to be present. Similarily, quantitative recovery of total and ionic fluoride from the 26 separate samples derived from a single plasma sample by gel chromatography was obtained. The detection of $\Delta F$ does not appear to be due to random analytical error as the frequency of occurrence of positive $\Delta F$ concentrations was many fold greater than would be expected on a random basis. That plasma $\Delta F$ was not occurring in a random fashion was shown by the strong correlation of plasma $\Delta F$ 
concentration on plasma total fluoride concentration. This result suggests that the $\Delta F$ in plasma is due to some orderly process.

Though the possibility cannot be totally eliminated the presence of $\Delta F$ does not appear to be due to a non-ionic fluoride airborne contaminant in $\mathrm{HF}$ chambers. Chamber air samples from atmospheres generated by both systems were ashed and no non-ionic fluoride component was detected, however the sampling system employed may not have collected such a non-ionic contaminant. No non-ionic fluoride component was detected in the aqueous hydrofluoric acid used in the aqueous system generator. It is possible that $\Delta F$ was present in these samples but at concentrations below the limit of sensitivity of the analytical methods. Increased $\Delta F$ concentrations were detected in tissues of rats exposed to $H F$ generated by the two systems. If $\Delta F$ was due to an airborne contaminant it would have to have been present in both systems. The nature of $\Delta F$ in the lung and kidney is not similar suggesting that if its presence were due to an airborne contaminant that contaminant was modified in vivo.

If $\Delta F$ were an airborne contaminant it certainly was not absorbed through the Iung. In rats exposed to HF generated by the aqueous system the increases in plasma $\Delta F$ during the post-exposure period could not be explained by the levels of $\Delta F$ in the lung. In fact $\Delta F$ concentrations in the lung increased during the post-exposure period as well. The source of $\Delta F$ may be the fur or the upper respiratory tract. Ashing of the upper respiratory tract rinses did not reveal the present of $\Delta F$ in this 
site, but this procedure was performed on rats exposed to HF generated by the compressed gas system so only minimal levels of $\Delta F$ would be expected to be present. Finally, not only have non-ionic fluoride fractions been detected in the tissue of several species by other investigators (Taves, 1968a; Guy, et al., 1977; Patterson, et al., 1977), but in one investigation increased dietary ionic fluoride intake resulted in increased plasma non-ionic fluoride concentrations (Ophaug and Singer, 1977). The differing response with respect to $\Delta F$ in rats exposed to HF generated by the aqueous or the compressed gas techniques suggests that $\Delta F$ is formed at some site in direct physical contact with HF. Airborne HF may be in differing physical forms in these two atmospheres. NIOSH (1976) states that HF forms a fume in moist air. Certainly the air over the hydrofluoric acid in the HF aqueous system is moist. In addition the process of bubbling air through the aqueous hydrofluoric acid certainly results in the formation of a few aqueous hydrofluoric acid droplets. The HF in the compressed gas tank is anhydrous and the chamber relative humidities were generally less than 258, so little fuming might be expected in these chamber atmospheres. If $\Delta F$ were due to the chemical reaction of fluoride with some component of biologic tissues then more might be formed in areas of high fluoride concentration, i.e. areas where droplets of hydrofluoric acid deposit. A similar process has been postulated to be of some importance in the potentiation of $\mathrm{SO}_{2}$ toxicity by particulate $\mathrm{NaCl}$ (Amdur, 1957). Certainly the dose dependence of plasma $\Delta \mathrm{F}$ 
concentration on airborne $H F$ concentration suggests that $\Delta F$ is derived from HF.

The effects of HF exposures in Charles River rats provide some slight evidence that the physiologic response(s) to ionic fluoride and $\Delta F$ is different. In the dose-response experiment dose-response relationships were evident in Blue Spruce rats between BUN and airborne HF concentration, BUN and plasma ionic fluoride concentration and BUN and plasma total fluoride concentration. These HF atmospheres were generated by the compressed gas technique. Charles River rats were exposed to $\mathrm{HF}$ generated by either the compressed gas technique or the aqueous system. In these rats a consistent relationship was evident only between BUN and plasma ionic fluoride concentration. The BUN in Charles River rats exposed to $26 \mathrm{mg} \mathrm{F} / \mathrm{m}^{3} \mathrm{HF}$ or $54 \mathrm{mg} \mathrm{F} / \mathrm{m}^{3} \mathrm{HF}$ generated by the compressed gas technique averaged 20.9 and 30.6 mgo respectively, the two values being statistically different at the $\mathrm{p}<0.05$ level. The BUN in Charles River rats exposed to $84 \mathrm{mg}$ $\mathrm{F} / \mathrm{m}^{3}$ by the aqueous system averaged $24.7 \mathrm{mg}$, a value between the levels present in the two lower HF exposure groups. The ionic fluoride concentration in the plasma of these $84 \mathrm{mg} \mathrm{F} / \mathrm{m}^{3}$ aqueous system generated HF exposed rats averaged between that in rats exposed to 26 or $54 \mathrm{mg} \mathrm{F} / \mathrm{m}^{3}$ while the total fluoride concentration, due to large amounts of $\Delta F$, averaged 2.5 fold higher than that in rats exposed to 26 or $54 \mathrm{mg} \mathrm{F} / \mathrm{m}^{3}$. Thus, as measured by increased BUN, the $r$ at kidney does not appear to respond to $\Delta F$ in the same manner as ionic $F^{-}$. 
The blood urea nitrogen (BUN) concentration is used as an indirect measure of renal toxicity. Urea is a major end product of protein metabolism and is excreted almost entirely via the kidney (Valtin, 1973). Thus, if kidney function were to be impaired and urea synthesis to remain unaltered, increased levels of BUN would ensue. Because elevated BUN levels may reflect increased hepatic urea synthesis, this finding cannot be interpreted a priori to indicate renal insufficiency. In the present studies the increased BUN in plasma of rats exposed to high concentrations of HF for 6 hours correlated well with the presence of pathologic lesions in the proximal tubules of the kidney. Together, these two findings provide strong evident that renal toxicity results from HF exposure. Whole body exposure to HF resulted in proximal tubular damage as indicated by the presence of cells containing pyknotic nuclei. In addition, the cytoplasm of pyknotic cells appeared eosinophilic compared to that of adjacent cells which were without visible nuclear damage. This renal lesion tended to increase in severity with increasing airborne HF exposure concentration. Tubular degeneration of the kidney, consisting of foci of pyknotic and karyolytic cells has been shown to occur in the rat after injection of $30 \mathrm{mg} / \mathrm{kg}$ fluoride as NaF (Taylor, et al., 1961). Proximal tubular necrosis of the rat kidney has been reported after two daily injections of $6 \mathrm{mg} \mathrm{F} / \mathrm{kg}$ as NaF (Mazze, et al., 1972). Damaged cells exhibited nuclear pyknosis and karyorrhexis and eosinophilic cytoplasm. These authors also reported that little damage was evident in other tubular cells. An increase in urine 
volume was reported following both these exposure regimens. Proximal tubular pyknosis and karyorrhexis has been reported in the rat kidney 4 hours after a 15 minute exposure to high levels of HF (greater than $480 \mathrm{mg} \mathrm{F} / \mathrm{m}^{3}$, actual airborne concentration unclear) for 15 minutes (Rosenholtz, et al., 1963). The similarity of effects reported in these fluoride treated rats and in $\mathrm{HF}$ exposed rats indicates the high probability that this renal damage is due to fluoride intoxication. The present study is the only one which gives tissue fluoride concentrations to correlate with this effect. Correlation of renal effects with airborne HF concentration may not be totally appropriate because of the effects of preening.

In whole body exposed rats sacrificed 6 hours after the end of a 6 hour exposure to $\mathrm{HF}$, marked increases in BUN or in renal pathology were not apparent unless the plasma fluoride concentration was higher than $2 \mu \mathrm{g} / \mathrm{ml}$ at the time of sacrifice. This is considered to be a toxic fluoride level. Plasma fluoride concentrations in rats intubated with an LD50 dose of fluoride (25 $\mathrm{mg} \mathrm{F} / \mathrm{kg}$ as $\mathrm{NaF}$ ) averaged $9.8 \mu \mathrm{g} / \mathrm{ml} 15$ minutes after dosing and $1.5 \mu \mathrm{g} / \mathrm{ml}$ 8-12 hours after dosing. (de Lopez, et al., 1976). Blood fluoride concentrations were 3 and $4 \mu \mathrm{g} / \mathrm{ml}$ in two human subjects who died 4 and 10 hours after accidental exposure to HF (Greendyke and Hodge, 1964). Death was attributed to pulmonary edema. Alterations in glucose metabolism as measured by ${ }^{14} \mathrm{CO}_{2}$ expiration during infusion of ${ }^{14} \mathrm{C}$-glucose, have been shown to occur in rats with plasma fluoride concentrations in this range 
(Knaus, 1970). Continuous intravenous infusion with $1.0 \mathrm{mg} \mathrm{F} /$ hour (as $\mathrm{NaF}$ ) for 2 hours resulted in a 208 reduction in $14 \mathrm{CO}_{2}$ expiration. Plasma fluoride concentrations at this time were approximately $4 \mu \mathrm{g} / \mathrm{ml}$. Infusion of fluoride at the same rate for longer periods or at higher rates for the same period result in a greater reduction in ${ }^{14} \infty_{2}$ production. Data on the ventilation rates during these exposures was not given, but fluoride inhibits several enzymes in the glycolytic pathway (Wi seman, 1966). Polyuric renal damage in the $r$ at has been associated with much lower plasma fluoride concentrations. Whitford and Taves (1973) observed a dose-dependent increase in urine flow rate in $200 \mathrm{~g}$ female Sprague-Dawley rats intravenously infused with various concentrations of $\mathrm{NaF}$ for 3 hours. At the lowest infusion rate, $0.06 \mathrm{mg} F /$ hour, urine flow rates were increased by an average of $658(p<0.001)$. Increased urine flow rates were evident after only 1 hour of infusion. Plasma fluoride concentrations averaged $0.6 \mu \mathrm{g} / \mathrm{ml}$ in these rats after 3 hours infusion. Plasma fluoride concentrations averaged $0.5 \mu \mathrm{g} / \mathrm{ml}$ in rats sacrificed immediately after whole body exposure to $10.2 \mathrm{mg} \mathrm{F} / \mathrm{m}^{3}$ for 6 hours. Plasma fluoride concentrations also averaged $0.5 \mu \mathrm{g} / \mathrm{ml}$ in rats sacrificed 6 hours after the exposure, however no diuretic effect was noticed during this 6 hour period or during any other post-exposure period. This may be due to sex or strain differences. Mazze, et al. (1973) showed that a dose regimen $(6.3$ $\mathrm{mg} F / \mathrm{kg} /$ day as $\mathrm{NaF}$ i.p. for 5 days) which resulted in a 4-fold increase in urine volume in Fisher 344 rats was without effect in 
Buffalo strain rats. The human is sensitive to fluoride induced diuresis. Diuretic effects of methoxyflurane anaesthesia have been shown in man with peak plasma ionic fluoride oncentrations of $1.0 \mu \mathrm{g} / \mathrm{ml}$ (Cousins and Mazze, 1973). During metabolism the fluoride ion is released from methoxyflurane. A diuretic response may have occurred in rats exposed to $\mathrm{HF}$ in the dose-response experiment. The urine excreted from the 6 hour exposure period from each group of rats was pooled so only one urine volume for each dose was obtained. These volumes in control, $11 \mathrm{mg} F / \mathrm{m}^{3}$ and $27 \mathrm{mg} \mathrm{F} / \mathrm{m}^{3}$ exposed rats were $0.5,1.2$ and 2.8 $\mathrm{ml} / \mathrm{rat}$ respectively. The interpretation of these results is not clear cut because during a similar period in the HF whole body retention experiment control rats excreted a mean volume of 2.3 $\mathrm{ml} /$ rat. Increased urine volumes were not detected in rats infused intravenously with $10.8 \mathrm{\mu g} \mathrm{F} / \mathrm{min}$ for 1 hour even though this infusion rate was 10 times the lowest effective dose of Whitford and Taves (1973). Species or sex differences might explain this discrepancy. Fluoride depleted rats nose-only exposed to $63 \mathrm{mg}$ $F / \mathrm{m}^{3}$ for 1 hour may have excreted more urine than the control group during the $0-7$ hour experimental period, however, the mean urine volumes in these two groups were not statistically different if data from every rat in each group was included in the analysis. Excreted urine volume during this period was no different from control levels in normal fluoride diet rats nose-only exposed to 75 $\mathrm{mg} F / \mathrm{m}^{3}$ for 1 hour. In summary, a clear cut diuretic response did not occur in rats exposed to $\mathrm{HF}$ by either the nose-only or whole body route. 
A considerable diuresis resulted from 6 hour whole body exposure to $24 \mathrm{mg} \mathrm{F} / \mathrm{m}^{3} \mathrm{NaF}$. Maximal 24 hour urine volume occurred on the third day after the start of exposure. During this time exposed rats excreted nearly 4 times more urine than controls. Urine specific gravity was decreased by exposure. The mean specific gravity was lowest in urine collected on the third experimental day. No change in protein excretion was evident at any time during the 8 day post-exposure period indicating that in the rat this is a very insensitive indicator of fluoride-induced renal toxicity. From the femoral fluoride content and urinary fluoride excretion of these $\mathrm{NaF}$ exposed rats it was estimated that $24 \mathrm{mg}$ fluoride was absorbed as a result of exposure compared to an estimate of only $4.5 \mathrm{mg}$ fluoride in the whole-body exposed HF retention experiment and $0.8 \mathrm{mg}$ in the nose-only fluoride depleted rat nose-only experiment. The large dose received by the NaF exposed animals may explain the greater diuretic response. Urine volume and specific gravity were sensitive measures of fluoride-induced renal toxicity in NaF dust exposed rats. Whitford and Taves (1973) reported a dose-dependent decrease in urine osmolarity accompanied the diuresis. Perhaps future studies of effects of occupatinal exposure to fluoride should include these parameters as measures of possible nephrotoxic effects. Previous investigations using medical history and physical examination (Rye, 1961; Raltreider, et al., 1972) and/or urinary protein excretion (Derryberry, et al., 1963; Dinman, et al, 1976) did not detect any effect of occupational fluoride exposure on renal function. There 
are three isolated reports of increased urine volume in humans exposed to airborne fluorides, however, in each case fluoride exposure is not the only explanation of the results. Rye (1961), in following the urinary fluoride excretion in a one individual exposed to airborne fluorides in a rock phosphate plant noticed that the individual experienced periodic episodes of diuresis. These diuretic periods did not occur on weekends and were not related to increased fluid intake. One of two individuals exposed to $3.3 \mathrm{mg} \mathrm{F} / \mathrm{m}^{3}$ gaseous fluorides for 8 hours in an investigation of fluoride metabolism (Collings, et al., 1951) experienced a diuresis on the day following exposure, but the author explains the phenomenon on the basis of the slightly increased fluid intake necessary to maintain urine flow rates high enough for 2 hour urine collections. Zober, et al. (1977) collected 24-hour urine samples from 18 individuals exposed to $\mathrm{HF}$ in the glass industry and from 9 clerical personnel from the same plant who were not exposed to HF. The author reports each individual urine volume, but does not discuss them. The volume of urine excreted in 24 hnurs by the HF exposed group was $1639 \pm 136 \mathrm{ml}$ (mean \pm S.E.M.) compared to $1203 \pm$ 111 for the control group. These two groups are significantly different at the p<0.05 levels. The exposed group, if their job entailed physical labor in the hot environment of a glass manufacturing plant may well have consumed more water than the control group. Data on water consumption was not given. Only one airborne fluoride determination was made at each of the 5 plant locations where these individuals worked and the air sampler 
placement at each location may not have been appropriate but the airborne HF concentrations ranged from $0.6-14.4 \mathrm{mg} \mathrm{F} / \mathrm{m}^{3}$. The N.I.O.S.H. recommended standard is $2.5 \mathrm{mg} \mathrm{F} / \mathrm{m}^{3}$ (NIOSH, 1976). The results of thse three investigations certainly do not indicate that nephrotoxicity results from exposure to low levels of atmospheric fluoride, however, they do point out the need for further investigations on the affects of occupational fluoride exposure on renal function.

Pulmonary function, as measured by forced expirations, was unaffected in 231 employees exposed to $\mathrm{HF}$ and other atmospheric fluorides in the aluminium industry (Kaltreider, et al., 1972). A slight increase in pulmonary disease detected by chest radiographs, physical examination and medical history was reported in employees exposed to airborne fluorides in a phosphate fertilizer plant by Derryberry, et al. (1963). However, several other investigations on occupational exposure to fluorides using similar diagnostic techniques detected no increase in pulmonary disease in fluoride exposed individuals (Machle and Evans, 1940; Rye, 1961; Kaltreider, et al., 1972). Accidental exposure to high concentrations of HF can lead to massive fatal pulmonary edema (Greendyke and Hodge, 1964). Pulmonary edema and hemorrhage of the lungs has been shown to occur in several species after exposure to high concentrations of HF (Machle, et al., 1934; Wohlslagel, et al., 1976; Di Pasquale and Davis, 1971). Several species also developed pulmonary edema during exposure to $25 \mathrm{mg} \mathrm{F} / \mathrm{m}^{3} \mathrm{HF}, 6$ hours per day, 6 days per week for 5 weeks (Stokinger, 1949). Pulmonary edema was not a 
common finding in rats exposed by the regimens used in the present studies.

Rats exposed to HF generated by the compressed gas technique did not develop pulmonary edema. Light microscopy and lung wet weight to dry weight ratios were used to assess edema. As discussed by Staub (1974), measurement of lung wet weight to dry weight ratio is the most sensitive measure of lung water content. A $10 \%$ increase in lung water content would have been detected by this technique. An increase in water content of this magnitude would in all probability be reflected histologically as interstitial swelling (Staub, 1974). It was not possible to assess any increases in the peribronchial or perivascular interstitial space histologically because of the underlying pulmonary disease in the rats used in this study. No alveolar flood was seen in any lung section.

Exposure to HF generated by the aqueous system resulted in a slight increase in pulmonary water content in Blue Spruce rats but not in rats obtained from Charles River Laboratories. The pulmonary fluoride burden at sacrifice was similar in both groups of rats suggesting that the Blue Spruce rats were more susceptible to HF-induced pulmonary edema than the Charles River rats. The differing response of Blue Spruce rats exposed to HF generated by the compressed gas or aqueous system may be due to differences in the regional deposition of this gas in the respiratory tract. A fraction of the atmospheric HF may exist as a fume or a mist in aqueous system generated atmospheres. This fume, if it exists, may 
penetrate to the lower airways more efficientiy than gaseous HF and, therefore, result in increased pulmonary damage. Comparison of pulmonary fluoride burdens in rats after exposure to HF generated by the aqueous or compressed gas system might be expected to provide some information on the process, however, the marked difference between the relative proportions of ionic $\mathrm{F}^{-}$and $\Delta \mathrm{F}$ in the lungs of rats exposed to $\mathrm{HF}$ generated by these two techniques makes direct comparisons impossible. Slight increases in lung water content occurred after whole body NaF exposure. Perhaps the fluoride ion plays some role in edema development in animals exposed to high concentrations of HF. One would suspect, however, that the acidity of HF would be of primary importance for the development of pulmonary edema.

Rosenholtz, et al. (1963) reported mucosal and submucosal necrosis accompanied by an acute inflammatory response of the anterior nasal cavity of rats after exposure to lethal concentrations of $\mathrm{HF}$ yet no pulmonary damage was noted. It was stated that lung sections were examined so the lack of comment on pulmonary damage implies that none was noted. The pulmonary effects observed in the present studies are quite similar to those of Rosenholtz, et al., (1963). No pulmonary effects were observed following whole body HF exposure, even in rats succumbing to the HF. Injury to the nasal cavity, as evidenced by discharge of fluid from the nares, did occur following exposure to high concentrations. These toxic effects correlate well with the regional deposition pattern of inhaled HF. Greater than 998 of 
inhaled HF deposits in the upper respiratory tract and this is the site that appears to be injured.

Rats dying after exposure to the HF were experiencing respiratory distress. The final acts of these rats was gasping for air. It was after these large abdominal breaths that fluid was discharged from the nares. The lung wet weight to dry weight ratio in these rats was significantly less than in oontrols. In the isolated cat lung, hypoxia resulted in a significant decrease in the pulmonary extravascular water content (Dawson, et al., 1978). It appears that these rats, being unable to breath through the mouth, (rats are not mouth breathers) are dying of anoxia because the nasal passages are blocked with fluid.

Machle, et al. (1934) noted that as HF exposure concentration increased the period between exposure and death shortened. A similar effect was noted in the present investigations. While exposure to 148 or $179 \mathrm{mg} \mathrm{F} / \mathrm{m}^{3}$ for 6 hours resulted in $100 \%$ mortality, all rats exposed to the lower concentration survived the exposure and succumbed during the post-exposure period and 4 of the 6 rats exposed to the higher concentration succumbed during the exposure. The dose-mortality curve for HF exposure under these conditions appears to be fairly steep. During the 12 hour experimental period no mortality was evident in rats exposed to 116 $\mathrm{mg} \mathrm{F} / \mathrm{m}^{3}$ while $100 \%$ mortality resulted from exposure to $148 \mathrm{mg}$ $\mathrm{F} / \mathrm{m}^{3}$. In two investigations (Di Pasquale and Davis, 1971; Wohlslagel, et al., 1976) marked differences in the LC50 of HF in the mouse and rat were reported. In both reports the LC50 in the 
mouse was approximately one-third of that for the rat. Deaths were attributed to pulmonary edema. Perhaps the upper respiratory tract of the mouse collects HF less efficiently than that of the rat. Machle, et al. (1934) also noted that exposure to HF slowed the respiratory rate, particularly in the rabbit. A similar effect was seen in the anaesthetized $r$ at during nose-only exposure to HF. Compounds which react with the ending of the trigeminal nerve in the nasal respiratory epithelium and produce a reflex depression in the respiratory rate are termed sensory irritants (Alarie, 1973). These compounds evoke a burning sensation in the nasal passages and induce tearing. Humans exposed to $48 \mathrm{mg} \mathrm{F} / \mathrm{m}^{3} \mathrm{HF}$ experienced marked nasal irritation. In the present studies and in those of Rosenholtz, et al. (1963) rats exposed to high concentrations of HF exhibited marked lacrimation. These results in toto provide strong evidence that HF is a sensory irritant. The high deposition of HF in the nasal cavity is certainly consistent with this hypothesis. In addition to experiencing nasal irritation, humans exposed to $26 \mathrm{mg} \mathrm{F} / \mathrm{m}^{3} \mathrm{HF}$ experienced tickling and discomfort of the larger airways (Machle, et al.., 1934) suggesting that the human nose is not as efficient at ollecting HF as the rat nose. Largent (1961) reported that humans exposed to $1.2-4 \mathrm{mg} \mathrm{F} / \mathrm{m}^{3}$ experienced nasal irritation, but no mention of irritation to the lower airways was made. Perhaps at airborne HF concentrations below the recommended airborne occupational standard of $2.5 \mathrm{mg} \mathrm{F} / \mathrm{m}^{3}$ (NIOSH, 1976) deposition of HF in the upper respiratory tract of humans is complete. 
If the deposition, distribution and excretion of inhaled HF is somewhat similar in the $m$ an and the $r$ at these studies suggest $a$ novel approach toward determining the extent of exposure to $\mathrm{HF}$. Currently, N.I.O.S.H. (1976) recommends monitoring of urinary fluoride excretion as this measure and the results of this study corroborate the usefulness of this as a tool. Fluoride which has been excreted in the urine represents HF which has been inhaled same time previously. In the rat following I hour nose-only exposure to HF the urine contained only $2 \%$ of the estimated inhaled dose. At this time large amounts of fluoride could be easily removed from the upper respiratory tract. Perhaps measurement of the fluoride concentration in nasal mucous might be a good tool to assess the extent of exposure occurring just prior to sample collection. Such a procedure might be particularly useful in trying to determine the extent of an acute exposure after an accident involving HF.

If a large fraction of inhaled HF deposits in the upper respiratory tract of the human as suggested by the deposition pattern in the rat then addition of particulate matter might increase the toxicity of HF if the gas were to adsorb to the particles and be carried into the lung. A similar mechanism has been postulated to be of importance in the potentiation of the response to $\mathrm{SO}_{2}$ and formaldehyde by sodium chloride aerosol (Amdur, 1959). The addition of alumina dust has been shown to be without effect on mortality caused by high airborne concentrations of $\mathrm{HF}$ (Wohlslagel, 1976). In light of the high affinity of 
fluoride for calcium phosphate it would be interesting to

investigate the effects of phosphate dusts on HF toxicity. Humans are exposed to both HF and phosphate dusts in the manufacture of phosphoric acid and phosphate fertilizers. 
The experiments described in this thesis provide quantitative information on the absorption, distribution and excretion of inhaled hydrogen fluoride. Total (ashed samples) and/or ionic (unashed samples) fluoride concentration in lung, plasma, kidney, trachea, femur, urine and feces of male Long Evans rats after 6 hour whole body HF exposure or 1 hour nose-only HF exposure were determined. The difference between total and ionic fluoride concentration in lung, plasma and kidney after HF exposure is referred to as the $\Delta F$ fraction and is attributed to the presence of a fluoride specie(s) which does not respond to the fluoride ion sensitive electrode.

After whole body exposure urinary fluoride excretion was many times greater than could be explained by the amount of HF inhaled. The experiments performed indicate that airborne HF deposits on the fur during exposure and is then ingested in the course of preening activity. In rats sacrificed 6 hours after 6 hour whole body exposure to different concentrations of HF generated by diluting the output of a compressed gas cylinder containing $18 \mathrm{HF}$ in nitrogen dose-dependent increases in total and ionic lung, plasma and kidney fluoride concentrations occurred. Plasma ionic fluoride concentration averaged from $0.6 \mu \mathrm{g} / \mathrm{ml}$ or $5.7 \mu \mathrm{g} / \mathrm{ml}$ after exposure to 11 or $116 \mathrm{mg} \mathrm{F} / \mathrm{m}^{3}$, respectively (control value 0.03 $\mu \mathrm{g} / \mathrm{ml})$. Renal toxicity, indicated by increased plasma urea levels and pyknosis of the proximal tubular epithelium was associated with plasma ionic fluoride concentrations in excess of 
$2.0 \mu \mathrm{g} / \mathrm{ml}$. A dose-dependent increase in plasma $\Delta \mathrm{F}$ with

airborne HF concentration was also evident. Plasma $\Delta F$ was

strongly correlated with the log of the plasma total fluoride

concentration. Plasma $\Delta F$ concentrations after exposures

generated by this technique averaged $7-188$ of the total fluoride concentration.

High $\Delta F$ concentrations were present in lung, plasma and kidney of rats whole body exposed to HF generated by bubbling clean room air through aqueous hydrofluoric acid. In some cases $\Delta F$ accounted for 808 of the total fluoride present. Sephadex G-25 gel chromatography of plasma suggested that the molecular weight of $\Delta F$ was less than 5000 daltons. Plasma $\Delta F$ could be separated from plasma ionic $\mathrm{F}^{-}$by the calcium phosphate adsorption technique of Venkateswarlu, et al. (1971) indicating that the fluoride in this fraction was non-ionizable.

Urinary fluoride excretion was elevated immediately after 1 hour nose-only exposure to $63 \mathrm{mg} \mathrm{F} / \mathrm{m}^{3}$ (generated by the compressed gas technique). Approximately 908 of the exess fluoride excreted as a result of exposure was eliminated within 24 hours of the start of exposure, the remaining $10 \%$ being excreted between 24 and 48 hours. A mean of 228 (std. dev. 58) of intraperitoneally or intratracheally injected fluoride (as NaF) was excreted by the rat within 24 hours. Excess urinary fluoride excretion was not detected after that time. After nose-only exposure urinary fluoride excretion accounted for approximately twice the fluoride estimated to be inhaled. The amount of fluoride on the fur covering the nose was of sufficient magnitude to account for the difference. 
Tissue fluoride concentrations were elevated by nose-only exposure and quickly returned to control levels. Plasma fluoride concentration was slightly elevated 24 hours after the start of exposure but was at control levels at 96 hours. In rats sacrificed at 7 hours lung fluoride concentration was no different from control. Kidney fluoride concentration was at control levels at 12 hours.

Immediately after nose-only exposure lung ionic fluoride concentration was less than plasma ionic fluoride concentration suggesting that the fluoride present in the lung had reached that site via plasma transport rather than by inhalation. In a separate experiment the upper respiratory tract of the rat was surgically isolated and HF Iaden air was drawn through the upper respiratory tract while the rat respired room air through an endotracheal tube. A dose-dependent increase in plasma ionic fluoride concentration in these upper respiratory tract exposed rats was evident, providing strong evidence that the fluoride ion is absorbed systemically from that site. The plasma ionic fluoride concentration in these rats was of sufficient magnitude to account for the plasma fluoride concentrations observed in intact nose-only exposed rats. Analysis of the airborne fluoride levels in air entering and leaving this site indicated that at airborne HF concentrations as high as $180 \mathrm{mg} \mathrm{F} / \mathrm{m}^{3}$ greater than 99.98 of airborne $\mathrm{BF}$ is removed during passage through the upper respiratory tract. 
In summary greater than 99.98 of inhaled HF appears to be deposited in the upper respiratory tract. HF deposited in this site can be absorbed systemically. Two forms of fluoride are present in the plasma of HF exposed rats, one ionic in nature, the other consisting of a low molecular weight non-ionizable fluoride specie (s) . 


\section{B IBLIOGRAPHY}

1. Alarie, Y. Sensory irritation by airborne chemicals. C.R.C. Crit. Rev. Toxicol. 2 : 299-363 (1973).

2. Amdur, M. O. The influence of aerosols upon the respiratory response of guinea pigs to sulfur dioxide. Am. Ind. Hyg. Assoc. J. 18: 149-155. (1957).

3. Amdur, M. O. The physiologic response of guinea pigs to atmospheric pollutants. Int. J. Air. Polln. 1: 170-183 (1959).

4. Amdur, M. O. Respiratory absorption data and $\mathrm{SO}_{2}$ dose-response curves. Arch. Environ. Hlth. 12: 729-732 (1966).

5. Bell, M. C., Merriman, G. M. and Greenwood, D. A. Distribution and excretion of $F^{18}$ fluoride in beef cattle. J. Nutr. $\underline{73}: 379-385$ (1961).

6. Carlson, C.H., Armstrong, W. D. and Singer, L. Distribution, migration and binding of whole blood fluoride evaluated with radiofluoride. Am. T. Physinl 199: 187-189 (1960a).

7. Carlson, C. H., Armstrong, W. D., Singer, L. and Henshaw, L. B. Renal excretion of radiofluoride in the dog. Am. J. Physiol. 198: 829-832 (1960b).

8. Carlson, C. H., Singer, L. and Armstrong, W. D. Radiofluoride distribution in tissues of normal and nephrectomized rats. Proc. Soc. Expt. Biol. Med. 103: $418-420(1960 c)$. 
BIBLIOGRAPHY (continued)

9. Cameron, G.R., Gaddum, J. H. and Short, R. H. D. The absorption of war gases by the nose. J. Pathol. 58: 449-455 (1946)

10. Chaney, A. I. and Marbach, E. P. Modified reagents for determination of urea and ammonia. Clin. Chem. 8: 130-132 (1962) .

11. Collings, G. H., Fleming, R. B. L. and May, R. Absorption and excretion of inhaled fluorides. Arch. Ind. Hlth. $\underline{4}$ : $585-590$ (1951).

12. Cousins, J. J. and Mazze, R. I. Methoxyfluorane nephrotoxicity. A study of dose response in man. J. Am. Med. Assoc. 225: $1611-1616$ (1973).

13. Cowell, D. C. The determination of fluoride ion concentration in biological fluids and in the serum and urine of fluoride treated patients with Paget's disease and osteoporosis, Med, Lab. Technol. $\underline{32}$; 73-89 (1975).

14. Dahl, A. R., Muggenburg, B. A. and Felicetti, S. A. Deposition of sulfuric acid mist in the respiratory tract of the dog, rat and guinea pig. Paper No. 4, Soc. of Toxicol. 18hㅡ Annual Meeting, New Orleans, IA (1979).

15. Dalhamn, T. and Sjoholm, J. Studies on $\mathrm{SO}_{2}, \mathrm{NO}_{2}$ and $\mathrm{NH}_{3}$ : Effect on ciliary activity in rabbit trachea of single in vitro exposure and resorption in rabbit nasal cavity. Acta Physiol. Scand. 58: 287-291 (1963). 
16. Davies, C. N. Filtration of droplets in the nose of the rabbit. Proc. Roy. Soc. Lond. Ser. B. 133: 282-299 (1946).

17. Dawson, C. A., Grimm, D. J. and Linehan, J. H. Influence of hypoxia on the longitudinal distribution of pulmonary vascular resistance. J. Appl. Physiol: Respirat. Environ. Excercise Physiol. 44: 493-498 (1978).

18. Derryberry, O. M., Bartholomew, M. D. and Fleming, R. B. L. Fluoride exposure and worker health. Arch. Environ. Hlth. $\underline{6}$ : 503-514 (1963).

19. Determann, Gel Chromatography, 2nd edition, Springer-Verlag New York, Inc. New York (1969).

20. Dinman, B. D., Backenstose, D. L., Carger, R. P., Bonney, T. B., Cohen, J. M., Colwell, M. O. A five-year study of fluoride absorption and excretion - Part 3. J. Occup. Med. $\underline{18}: 17-20(1976)$.

21. Di Pasquale, L. C. and Davis, H. V. The acute toxicity of brief exposure to hydrogen fluoride, hydrogen chloride, nitrogen dioxide, and hydrogen cyanide singly and in combination with carbon monoxide. Wright Patterson Air Force Base AMRL-TR-71-120, Paper No. 20: 279-290 (1971).

22. Dixon, W. J. and Massey, F. J. Introduction to Statistical Analysis. MCGraw-Hill, New York (1969).

23. Egle, J. L. Retention of inhaled formaldehyde, proprionaldehyde, and acrolein in the dog. Arch. Environ. Hlth. 25: 119-124 (1972). 
BIBLIOGRAPHY (conti nued)

24. Ericsson, Y. Blood fluoride clearance in rats differing in age or previous fluoride exposure Investigations using radioactive fluorine. Acta Odont. Scand. 24: 393-404 (1966).

25. Ericsson, Y. Fluoride reactions and equilibria with hard tissue apatites. Collog. Int. C.N.R.S. 230 (Phys.-Chim. Cristallogr. Apatites Interet Biol.): 411-417 (1975).

26. Ericsson, Y. and Ullberg, S. Autoradiographic investigations of the distribution of F18 in mice and rats. Acta. Odont. Scand. 16: 363-374 (1958).

27. Frank, N. R., Yoder, R. E., Brain, J. D. and Yokoyama, E. $\mathrm{SO}_{2}\left({ }^{35} \mathrm{~S}\right.$ labeled) absorption by the nose and mouth under conditions of varying concentration and flow. Arch. Environ. H1th. 18: 315-322 (1969).

28. Frant, M. S. and Ross, J. W. Electrode for sensing fluoride ion activity in solution. Science 154: 1553-1554 (1966).

29. Greendyke, R. M. and Hodge, H. C. Accidental death due to hydrofluoric acid. J. Forensic Sci. $\underline{9}$ : 383-390 (1964).

30. Guy, W. S., Taves, D. R. and Brey, W. S. Organic fluorocompounds in human plasma: prevalence and characterization. In Biochemistry Involving Carbon-Fluorine Bonds, R. Fuller (ed.), A.C.S. Symposium Series 28, Am. Chem. Soc., Washington, D.C. (1976) pp. 117-113.

31. Guyton, A. C. Measurement of the respiratory volumes of laboratory animals. Am J. Physiol. 150: 70-77 (1947). 
BIBLIOGRAPHY (continued)

32. Hall, L. L., Kilpper, R. W., Smith, F. A., Morken, D. A. and Hodge, H. C. Kinetic model of fluoride metabolism in the rabbit. Environ. Res. 13: 285-302 (1977).

33. Hall, L. L., Smith, F. A., de Lopex, O. H., Gardner, D. E. Direct potentianetric determination of total ionic fluoride in biological fluids. Clin. Chem. 18: 1455-1458 (1972).

34. Hennon, D. R., Stookey, G. K. and Muhler, J. C. Blood and urinary fluoride levels in humans associated with ingestion of sodium fluoride-containing vitamin tablets. J. Dent. Res. 48: $1211-1215$ (1969).

35. Hodge, H. C. and Smith, F. A. Occupational fluoride exposure. J. Occup. Med. 19: 12-39. (1977).

36. Jordan, E. O. and Carlson, A. J. Ozone: its bactericidal, physiologic and deodorizing action. J. Am. Med. Assoc. 61: 1008-1012 (1913).

37. Kaltreider, N. L., Elder, M. J., Cralley, L. V. and Colwell, M. O. Health survey of aluminum workers with special reference to fluoride exposure. J. Occup. Med. 14: 531-541 (1972).

38. Knaus, R. M. The fate of fluoride and the effect of fluoride on glucose metabolism in intact rats. Ph.D. Thesis, Oregon State Univ. (1970).

39. Knaus, R. M., Dost, F. N., Johnson, D. E. and Wang, C. H. Fluoride distribution in rats during and after continuous infusion of Na18 F. Toxicol. Appl. Pharmacol. 38: 335-343 (1976) . 
BIBLIOGRAPHY (continued)

40. Largent, E. J. Ingestion, inhalation, excretion and storage of fluoride by man. In Fluorosis: The Health Aspects of Fluorine Compounds, Ohio State Univ. Press, Columbus, Ohio, (1961) pp. 22-140.

41. Leach, L. J. A laboratory test chamber for studying air-borne materials. Univ. of Rochester Atomic Energy Project Report No. UR-629 (1963).

42. Leach, L. J., Spiegel, C. J., Wilson, R. H., Sylvester, G. E. and Lauterbach, R. E. A multiple chamber exposure unit designed for chronic inhalation studies. Am. Ind. Hyg. Assoc. J. 20: 13-22 (1959).

43. Leech, H. R. The physical and chemical properties and uses of hydrogen fluoride and its aqueous solutions. The hydrogen fluoride molecule. in A Comprehensive Treatise on Inorganic and Theoretical Chemistry, Vol II, Supp. 1, Mellor, J. W. Longmans, Green and Co., Ltd., London (1956) pp. 90-100.

44. de Lopez, O. H., Smith, F. A. and Hodge, H. C. Plasma fluoride concentrations in rats acutely poisoned with sodium fluoride. Toxicol. Appl. Pharmacol. 37: 75-83 (1976).

45. Lorin, M. L., Gaerlan, P. F. and Mandel, I. D. Quantitative composition of nasal secretions in normal subjects. J. Lab. Clin. Med. 80: 275-281 (1972).

46. Machle, W. and Evans, E. E. Exposure to fluorine in industry. J. Ind. Hyg. Toxicol. 22: 213-217 (1940). 
BIBLIOGRAPHY (continued)

47. Machle, $W$. and Kitzmiller, $k$. The effects of the inhalation of hydrogen fluoride. II. The response following exposure to low concentration. J. Ind. Hyg. 17: 223-229 (1935).

48. Machle, W. and Scott, E. W. The effects of the inhalation of hydrogen fluoride. III. Fluorine storage following exposure to sub-lethal concentrations. J. Ind. Hyg. 17: 230-240 (1935) •

49. Machle, W., Thamann, F., Kitzmiller, R. and Cholak, J. The effects of inhalation of hydrogen fluoride. I. The response following exposure to high concentrations. J. Ind. Hyg. 16: 129-145 (1934).

50. Masterton, W. L. and Slowinski, E. J. Chemical Principles, W. B. Saunders Co., Philadelphia, PA, (1969) pp. 217-218.

51. Mazze, R. I., Cousins, M. J. and Kosek, J. C. Dose-related methoxyflurane nephrotoxicity in rats: A biochemical and pathologic correlation. Anesthesiol. 36: 571-587 (1972).

52. Ma 7.7., R. I., Cousins, M. J. and Rocck, J. C. Strain differences in metabolism and susceptability to the nephrotoxic effects of methoxyflurane in rats. J. Pharmacol. Expt1. Ther. 184: 481-488 (1973).

53. Mercer, T. T. Aerosol Technology in Hazard Evaluation. Academic Press, New York, (1973) pp. 353-356.

54. Mercer, T. T., Tillery, M. I. and Newton, G. J. A multistage low flow rate cascade impactor. Aerosol Sci. 1: 9-15 (1970). 
BIBLIOGRAPHY (continued)

55. Mueller, R. F. Sources of $\mathrm{HCl}$ and HF in the atmosphere of Venus. Nature $\underline{220}: 55-57$ (1968).

56. National Institute for Occupational Safety and Health. Criteria for a recommended standard... Occupational exposure to hydrogen fluoride. HEW Publication No. (NIOSH) 76-143, U.S. Dept. of Health, Education and Welfare, Public Health Services, Center for Disease Control, National Institute for Occupation Safety and Health, Rockville, MD (1976).

57. Olver, R. E., Davis, B., Marin, M. G. and Nadel, J. A. Active transport of $\mathrm{Na}^{+}$and $\mathrm{Cl}^{-}$across the canine tracheal epithelium in vitro. Am. Rev. Resp. Dis. 112: $811-815$ (1975) .

58. Olver, R. E. and Strang, L. B. Ion fluxes across the pulmonary epithelium and the secretion of lung liquid in the foetal lamb. J. Physiol. 241: 327-357 (1974).

59. Ophaug, R. H. and Singer, L. Influence of variations in fluoride intake on the ionic and bound fractions of plasma and muscle fluoride. Proc. Soc. Exptl. Biol. Med. 155: 23-26 (1977) •

60. Palecek, F. Measurement of ventilatory mechanics in the rat. J. Appl. Physiol. 27: 149-156 (1969) .

61. Patten, J. R., Whitford, G. M., Stringer, G. I. and Pashley, D. H. Oral absorption of radioactive fluoride and iodide in rats. Arch. Oral Biol. 23: 215-217 (1978). 
BIBLIOGRAPHY (continued)

62. Patterson, C. M., Kruger, B. J. and Daley, T. J. Differences in fluoride levels in the blood between sheep, rabbit and rat. Arch. Oral Biol. 22: 419-423 (1977).

63. Reed, G.W. Fluorine in stone meteorites. Geochim. Cosmochim. Acta. 28: 1729-1743 (1964).

64. Reed, G. W., Jovanovics, S. and Fuchs, L. H. Trace elements and accessory minerals in lunar samples. Science 167: $501-503(1970)$.

65. Rosenholtz, M. J., Carson, T. R., Weeks, M. H., Wilinski, F., Ford, D. F. and Oberst, F. W. A toxicopathologic study in animals after brief single exposure to hydrogen fluoride. Am. Ind. Hyg. Assoc. J. $\underline{24}: 253-261$ (1963).

66. Rye, W. A. Fluorides and phosphates-clinical observations of employees in phosphate operation. Proc. 13th Internat. Congr. Occup. Med. (1961) pp. 61-64.

67. Savchuck, W. B. and Armstrong, W. D. Metabolic turnover of fluoride by the skeleton of the rat. J. Biol. Chem. 193: $575-585$ (1951).

68. Schlatz, L. Calcium and hormone interactions with isolated liver plasna membranes. Ph.D. Thesis, Univ. of Rochester (1971) .

69. Smith, F. A. unpublished results (1975).

70. Smith, F. A. Metabolism of inorganic fluoride. In: Handbuch der experimentellen pharmakologie, vol. XX-I, Pharmacology of fluorides, F. A. Smith (ed.), Springer-Verlag New York, Inc., New York, (1966) pp. 53-140. 
BIBLIOGRAPHY (continued)

71. Smith, F. A. and Gardner, D. E. A preliminary investigation of blood fluoride levels following exposure to hydrogen fluoride at a concentration of approximately $29 \mathrm{mg} / \mathrm{m}^{3}$. Univ. of Rochester Atomic Energy Project Report No. UR-77 (1949).

72. Smith, F. A., Gardner, D. E. and Hodge, H. C. Investigations on the metabolism of fluoride. 'III. Effects of acute renal tubular injury on urinary excretion of fluoride by the rabbit. Arch. Ind. Hlth. el: 2-10 (1955).

73. Smith, F. A., Gardner, D. E., Leone, N. C. and Hodge, H. C. The effects of the absorption of fluoride. V. The chemical determination of fluoride in human soft tissues following prolonged ingestion of fluoride at various levels. Arch. Ind. Hlth. 21 : 330-332 (1960).

74. Smith, F. A. and Hodge, H. C. Airborne fluorides and man: Part 1. C.R.C. Crit. Rev. environ. Control. 8: 293-371 (1979).

75. Speizer, F. E. and Frank, N. R. The uptake and release of $\mathrm{SO}_{2}$ by the human nose. Arch. Environ. H1th. 12: 725-728 (1966).

76. Staub, N. C. Pulmonary edema. Physiol. Rev. 54: 678-811 (1974) .

77. Etokinger, H. E. Toxlelty following 1nhalation of fluorine and hydrogen fluoride. In Pharmacology and Toxicology of Uranium Compounds, National Nuclear Energy Series VI-1, C. Voegtlin and H. C. Hodge (eds.), MCGraw-Hill, New York, (1949) pp. $1021=1057$. 
BIBLIOGRAPHY (continued)

78. Strandberg, L. G. $\mathrm{SO}_{2}$ absorption in the respiratory tract. Arch. Environ. Hlth. 9: 160-166 (1964).

79. Taves, D. R. Evidence that there are two forms of fluoride in human serum. Nature 217: 1050-1051 (1968a).

80. Taves, D. R. Electrophoretic mobility of serum fluoride. Nature $\underline{220}: 582-583(1968 b)$.

81. Taylor, J. M., Scott, J. K., Maynard, E. A., Smith, F. A. and Hodge, H. C. Toxic effects of fluoride on the rat kidney. I. Acute injury from single large doses. Toxicol. Appl. Pharmacol. $\underline{3}:$ 278-289 (1961).

82. Thomas, D. J. Characteristics and modification of methylmercury accumulation in rat cerebrum. Ph.D. Thesis, Univ. of Rochester, Rochester, NY (1978).

83. Valtin, H. Renal Function: Mechanisms Preserving Fluid Balance in Health. Little, Brown and Co., Boston, (1973) p. 136 .

84. Vaughan, T. R., Jennelle, L. F., Lewis, T. R, Long-term exposure to low levels of air pollutants. Effects on pulmonary function in the beagle, Arch. Environ. Hlth. 19: 45-50 (1969).

85. Venkateswarlu, P. Fallacies in the determination of total fluorine and nonionic fluorine in the diffusates of unased sera and ultrafiltrates. Biochem. Med. 14: 368-377 (1975).

86. Venkateswarlu, P. Determination of fluorine in biologic materials. Methods Biochem. Anal. 24: 93-201 (1977). 
BIBLIOGRAPHY (continued)

87. Venkateswarlu, P., Singer, L. and Armstrong, W. D. Determination of ionic (plus ionizable) fluoride in biological fluids. Procedure based on adsorption of fluoride ion on calcium phosphate. Analyt. Biochem. 42: 350-359 (1971).

88. Wadhwani, T. K. Metabolism of fluorine. Absorption, retention, distribution and elimination of fluorine, and its effect on the vitamin C content of different tissues, and on the iodine content of thyroids of rats and monkeys. J. Ind. Inst. Sci. 35: 354-362 (1953).

89. Wallace, P. C. The metabolism of fluoride in normal and chronically fluorosed rats. Ph.D. Thesis, Univ. of Calif., Berkeley (1953).

90. Wallace-Durbin, P. The metabolism of fluorine in the rat using $\mathrm{F}^{18}$ as a tracer. J. Dent. Res. $\underline{33}$ : 789-800 (1954).

91. Whitford, G. M. and Taves, D. R. Fluoride-induced diuresis: Renal-tissue solute concentrations, functional, hemodynanic and histologic correlates in the rat. Anesthesiol. 39: 416-427 (1973).

92. Wiseman, A. Effect of inorganic fluoride on enzymes. in Handbuch der Experimentellen Pharmakologie Vol xx/2, Pharmacology of fluorides. Smith, F. A. (ed.). Springer-Verlag New York, Inc., New York (1970) pp. 48-97. 
BIBLIOGRAPHY (continued)

93. Wohlslagel, J., Di Pasquale, L. C. and Vernot, E. H. Toxicity of solid rocket motor exhaust-effects of $\mathrm{HCl}, \mathrm{HF}$ and alumina on rodents. J. Combust. Toxicol. $\underline{3}$ : 61-70 (1976).

94. Yokoyama, E. and Frank, R. Resporatory uptake of ozone in dogs. Arch. Environ. H1th. 25: 132-138 (1972).

95. Yokoyama, E., Yoder, R. E. and Frank, N. R. Distribution of ${ }^{35} \mathrm{~S}$ in the blood and its excretion of dogs exposed to ${ }^{35} \mathrm{SO}_{2}$. Arch. Environ. Hlth. 22: 389-395 (1971).

96. Zipkin, I. and Leone, N. C. Rate of urinary fluoride output in normal adults. Am. J. Pub. Hlth. 47: 848-851 (1957).

97. Zipkin, I. and Likins, R. C. Absorption of various fluorine compounds from the gastrointestinal tract of the rat. Am. J. Physiol. 191: 549-550 (1957).

98. Zober, A., Geldmacher, M., Mallinckrodt, V. and Schaller, K. H. Renal fluoride excretion as a useful parameter for monitoring hydrofluoric acid-exposed persons. Int. Arch. Occup. Environ. Hlth. 40 : 13-24 (1977). 